$$
\text { UNIVERSIDADE DE SÃO PAULO }
$$

FACULDADE DE FILOSOFIA, LETRAS E CIÊNCIAS HUMANAS DEPARTAMENTO DE LETRAS CLÁSSICAS E VERNÁCULAS PROGRAMA DE PÓS-GRADUAÇÃO EM ESTUDOS COMPARADOS DE LITERATURAS DE LÍNGUA PORTUGUESA

\title{
PERCURSO DO ÓRFÃO NA LITERATURA INFANTIL/ JUVENIL, DA ORALIDADE À ERA DIGITAL: A TRAJETÓRIA DO HERÓI SOLITÁRIO
}




\section{UNIVERSIDADE DE SÃO PAULO}

FACULDADE DE FILOSOFIA, LETRAS E CIÊNCIAS HUMANAS DEPARTAMENTO DE LETRAS CLÁSSICAS E VERNÁCULAS PROGRAMA DE PÓS-GRADUAÇÃO EM ESTUDOS COMPARADOS DE LITERATURAS DE LÍNGUA PORTUGUESA

\section{PERCURSO DO ÓRFÃO NA LITERATURA INFANTIL/ JUVENIL, DA ORALIDADE À ERA DIGITAL: A TRAJETÓRIA DO HERÓI SOLITÁRIO}

DissertaÇÃo APRESENTAdA AO PROGRAMA DE PÓSGRADUAÇÃO EM ESTUDOS COMPARADOS DE LITERATURAS DE LÍNGUA PORTUGUESA DA FACULDADE DE FILOSOFIA, LETRAS E CIÊNCIAS HUMANAS DA UNIVERSIDADE DE SÃO PAULO PARA O TíTULO DE MESTRE EM LETRAS.

ORIENTADORA:

PROF ${ }^{a}$ DR ${ }^{a}$ MARIA LÚCIA PIMENTEL SAMPAIO GÓES

SÃO PAULO

2006 
Aos meus pais,

Zelia e Odon

À minha avó,

Maria Luiza

Aos meus irmãos,

Elis, Omar, Elio e Lino

Aos meus tios,

Francisco e Lilia

Aos meus sobrinhos,

Leonardo e Luana

porque nunca se está só quando se tem uma família. 
AGRADECIMENTOS 
À Profa. Dra. Maria Lúcia Pimentel de Sampaio Góes, pelas oportunidades oferecidas a mim, como sua aluna de Graduação e de Pós-Graduação, e, principalmente, pelo fornecimento de material e pela disponibilidade para orientar este trabalho.

À minha mãe, Profa. Dra. Zelia de Almeida Cardoso, pelo incentivo, pelos ensinamentos constantes, pelas revisões do texto, e, sobretudo, pelo exemplo de dedicação simultânea à família, ao magistério e à pesquisa.

Ao meu pai, Prof. Odon Almeida Cardoso, pelo interesse e pela sempre pronta disposição em ajudar, especialmente nas traduções e revisão dos textos em língua portuguesa e inglesa.

À minha irmã, Profa. Dra. Elis de Almeida Cardoso Caretta, pelo incentivo e pelas contribuições e troca de idéias sobre este trabalho.

Ao Prof. Dr. José Nicolau Gregorin Filho e ao Prof. Dr. José Maria Rodrigues Filho, pelas importantes contribuições oferecidas por ocasião do Exame de Qualificação realizado para a aprovação desta dissertação.

Ao escritor, ilustrador e pesquisador Ricardo Azevedo, pelo incentivo e pela disponibilidade de empréstimo de material para a realização desta pesquisa.

Aos colegas Antonio Sampaio Dória, Euclides Lins e Ivete Irene dos Santos, pelo importante convívio e intercâmbio de materiais e idéias durante os cursos de PósGraduação.

A todos os funcionários e professores do Colégio Presbiteriano Mackenzie Tamboré, em especial à Profa. Vera Mendes, Sra. Olga Bosniac, Profa. Eliana Neves e Profa. Yooko Konishi, pelo constante incentivo e apoio à realização deste trabalho.

Aos ex-companheiros de trabalho do Departamento de Medicina Legal, Ética Médica e Medicina Social e do Trabalho da Faculdade de Medicina da Universidade de São Paulo, em especial ao Dr. José Arnaldo Soares Vieira, pelos importantes anos de convivência e pelo exemplo de dedicação à pesquisa.

Ao meu irmão, Lino de Almeida Cardoso, e aos amigos, Gabriel Cheung Augusto, Vera Lucia Zaher e Cheung Sai Kit, pela constante troca de idéias a respeito dos temas que moveram esta dissertação desde o seu projeto.

A todos os professores do Curso de Letras da Faculdade de Filosofia, Letras e Ciências Humanas da Universidade de São Paulo, que em muito contribuíram para minha formação no período da Graduação; a todos os familiares e amigos que sempre me incentivaram desde meu ingresso na Pós-Graduação, contribuindo direta ou indiretamente para a realização deste trabalho, deixo meus sinceros agradecimentos. 
SUMÁRIO 


\section{SUMÁRIO}

Resumo.

Abstract

Considerações Iniciais

Capítulo 1 - Percurso do órfão na Literatura - As origens.

$1.1 \mathrm{O}$ órfão nas narrativas populares.......................................................... 24

1.1.1 Natureza do conto popular......................................................... 27

1.1.2 Percurso do órfão no conto popular............................................. 31

1.2 O órfão nos contos de fadas.............................................................. 45

1.2.1 Natureza dos contos de fadas.................................................... 46

1.2.2 Conto de fadas $x$ conto maravilhoso ............................................ 50

1.2.3 Percurso do órfão nos contos de fadas........................................... 54

Capítulo 2 - As pedras do caminho: desvios e atalhos na trajetória do órfão..... 59

2.1 Desvios: a perversidade, o ciúme e a maldade no caminho do órfão........ 62

2.1.1 A figura da madrasta..................................................................... 64

2.1 .2 Irmãos ciumentos.................................................................... 80

2.1.3 Falsos amigos e oportunistas................................................ 90

2.2 Atalhos: a amizade, o sobrenatural e a benevolência no caminho do órfão.

2.2.1 A figura da "fada-madrinha".....

2.2.2 Os amigos e a ajuda sobrenatural: amuletos e objetos mágicos......

Capítulo 3 - O órfão na atualidade em três diferentes mídias: Literatura, Quadrinhos e Cinema.

3.1 Presença do órfão em diferentes mídias............................................... 120

3.1.1 O órfão na literatura.................................................................... 121

3.1.1.1 - Harry Potter e a literatura - o suporte original................. 134

3.1.1.2 - A obra................................................................... 136

3.1.1.3 - O enredo............................................................ 137

3.1.1.4 - Desdobramentos.................................................... 142 
3.1.2 O órfão nos quadrinhos........................................................... 145

3.1.2.1 - Peter Parker e os quadrinhos - o suporte original............. 154

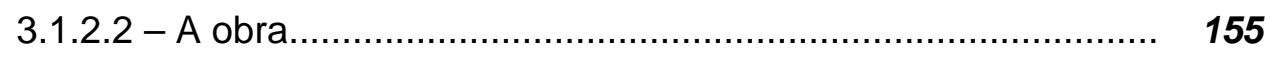

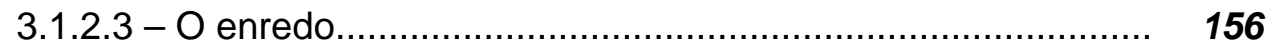

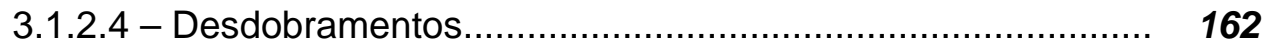

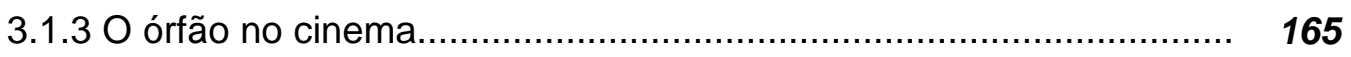

3.1.3.1 - Luke Skywalker e o cinema - o suporte original................ 175

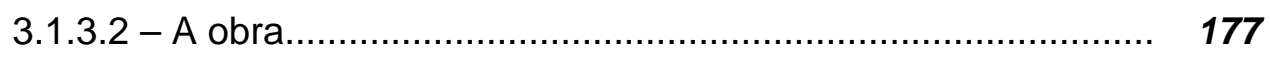

3.1.3.3 - O enredo............................................................ 178

3.1.3.4 - Desdobramentos....................................................... 181

3.2 Percurso do órfão na atualidade: um estudo das trajetórias de Harry Potter, Peter Parker e Luke Skywalker.......................................... 184

3.2.1 Partida.............................................................................. 186

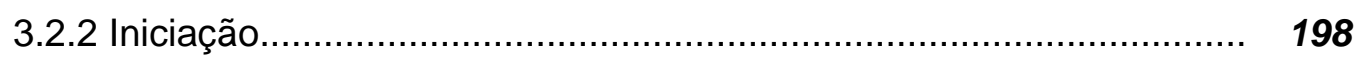

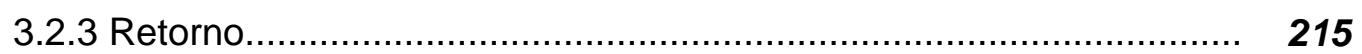

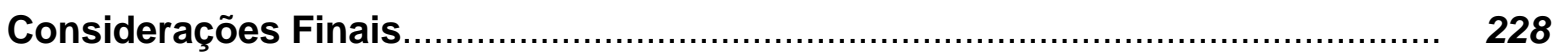

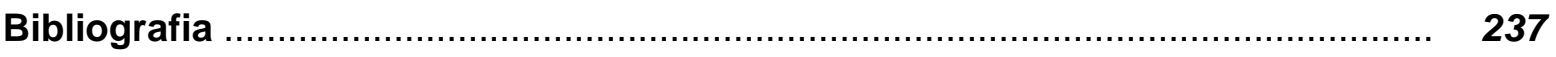

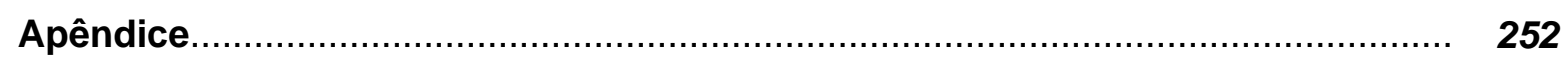


Resumo 
CARDOSO, LAís DE ALMEIDA. Percurso do órfão na Literatura Infantil/ Juvenil, da oralidade à era digital: a trajetória do herói solitário. São Paulo, FFLCH (USP), 2006. 282p. Dissertação [MESTRADO].

A orfandade é um tema bastante recorrente na literatura infantil e juvenil. Desde as antigas narrativas orais, como os contos de fadas, por exemplo, o arquétipo do órfão é revisitado regularmente na construção de diferentes personagens, sendo mantida, porém, uma estrutura básica predominante, principalmente no que concerne à sua trajetória. Investigar a recorrência dessa temática, partindo da análise de alguns contos populares até alcançar as mais recentes obras voltadas para o público jovem, foi um dos objetivos desta pesquisa. Uma outra meta foi estabelecer paralelos e divergências entre as figuras secundárias que compõem essas narrativas, como as madrinhas, as madrastas, os irmãos, os amigos, os seres mágicos, entre outros, e focalizar o papel que elas desempenham na trajetória do órfão, agindo ora como "desvios", ora como "atalhos" em seu caminho. Um terceiro propósito da dissertação foi estudar a circulação da personagem órfã contemporânea entre a literatura e outras mídias, como as histórias em quadrinhos $(\mathrm{HQ})$ e o cinema. Para isso, tomamos três personagens da ficção criadas originalmente para três diferentes suportes - Harry Potter (literatura), Peter Parker (HQ) e Luke Skywalker (cinema) - e procuramos estabelecer similaridades e divergências em três momentos de seus percursos: partida, iniciação e retorno. Ao compararmos as trajetórias desses três heróis órfãos, podemos perceber as visíveis intersecções entre elas e somos levados a crer que, mesmo modificadas pelos estilos literários e pelas mídias que lhes servem de suporte, essas personagens solitárias conservam, contudo, a essência das características de seu remoto substrato popular, proveniente da oralidade.

Palavras-chave: órfão; literatura infantil/ juvenil; herói solitário; mídias; madrastas/ madrinhas 
ABSTRACT 
CARDOSO, LAÍS DE ALMEIDA. The orphan's course in Literature for Children and Youths, from orality to digital age: the path of a solitary hero. São Paulo, FFLCH (USP), 2006. 282p. Dissertation [MASTER].

Orphanhood is quite a common theme in Children's Literature. From the old oral stories, as the fairy tales, for instance, the orphan archetype is regularly used in order to build different characters, keeping, however, a predominant basic structure, chiefly with regard to his path. Investigating the frequency of such a theme starting from the analysis of some popular tales and finally reaching the most recent works, offered to young people, was one of the purposes of this research. Another aim was to establish parallels and divergences ocurring to secondary characters that take part in those narratives, as the godmothers, stepmothers, brothers and sisters, magic creatures, among others, and focusing the role they play in the development of the orphan course, acting sometimes as "sidetracks", sometimes as "shortcuts" in his way. A third goal of this work was to study the circulation of the contemporary orphan character both in literature and other mass media, as comics and movies. For this purpose we chose three fiction characters, created originally for three different supports - Harry Potter (literature), Peter Parker (comics) and Luke Skywlaker (movies) - and tried to show similarities and differences in three moments of their route: start, initiation and return. Comparing the footsteps of those three orphan heroes, we may note the visible intersections among them and take into account that, even changed by literary style and mass media which support them, those solitary characters keep, nevertheless, the essence of the characteristics of their ancient popular substractum, coming from orality.

Key-words: orphan tales; Children's Literature; solitary hero; mass media; godmothers/ stepmothers. 
Não precisamos correr sozinhos o risco da aventura, pois os heróis de todos os tempos a enfrentaram antes de nós. O labirinto é conhecido em toda a sua extensão. Temos apenas de seguir a trilha do herói... e lá, onde pensávamos estar sós, estaremos na companhia do mundo todo.

(Joseph Campbell) 
CONSIDERAÇÕES INICIAIS 
Contos cujos protagonistas são órfãos compõem o repertório literário da maioria das crianças em qualquer parte do mundo.

Ao se relembrarem narrativas lidas ou ouvidas na infância, especialmente aquelas rotuladas como "clássicos infantis", é impossível deixar de notar a presença da orfandade na caracterização de diversas personagens, sobretudo daquelas com papel de destaque nas tramas.

Mesmo quando ainda não dominam o código escrito, praticamente desde o berço, as crianças acostumam-se a ouvir contos fantásticos de florestas e castelos, animais e objetos mágicos, seres encantados, fadas, bruxas, dragões, feiticeiros, príncipes e princesas, madrinhas, madrastas e órfãos...

Bons exemplos podem ser encontrados naquelas que talvez sejam as narrativas mais contundentes a pontuar o imaginário infantil: os contos de fadas. Nesse contexto não são raros os casos de personagens órfãs propriamente ditas, como Cinderela e Branca de Neve, ou órfãos por circunstância, como João e Maria e o Patinho Feio.

Porém o tema não se restringe ao universo do maravilhoso. À medida que a criança cresce e aprende a ler, sua atenção volta-se à possibilidade de explorar um mundo novo; assim, naturalmente deixa de lado os contos infantis para mergulhar em páginas mais densas, repletas de ação e mistério, além de transitar livremente do ágil e dinâmico mundo dos quadrinhos aos efeitos especiais dos filmes e animações. Independentemente de suas escolhas 
culturais e de entretenimento, o jovem não se desvencilhará com facilidade das personagens órfãs que lhe cruzam o caminho.

Investigar a recorrência dessas personagens, partindo das narrativas orais até alcançar os dias de hoje, foi um dos objetivos desta dissertação. Uma outra meta era estabelecer alguns paralelos e divergências entre as figuras secundárias que compõem essas narrativas e avaliar a relevância dessas personagens na trajetória do órfão. Um terceiro propósito foi estudar a circulação da personagem órfã contemporânea entre a literatura e outras mídias, como as histórias em quadrinhos (HQ) e o cinema.

Sendo assim, distribuímos o texto principal desta dissertação em três capítulos centrais, um para cada uma das metas acima traçadas.

No primeiro capítulo, abordamos o órfão nos contos populares e contos de fadas, tendo como pressuposto o fato de essas narrativas configurarem a base da literatura infantil e juvenil moderna. Assim, procuramos reconstruir o "arquétipo do órfão", isto é, o "modelo" que originou recorrências diferentes porém constantes ao protótipo, a cada época e a cada suporte utilizado.

No segundo capítulo, o foco da dissertação desloca-se do protagonista para observar mais pormenorizadamente as figuras que atuam de modo secundário - não obstante crucial - nesses enredos. Destacamos, pois, as madrastas, os irmãos, as madrinhas e os amigos, personagens que foram classificadas como "desvios" ou "atalhos" no caminho do órfão, conforme seu papel no desenrolar da trama. 
No terceiro e último capítulo, analisamos três personagens órfãs contemporâneas, pertencentes inicialmente a três diferentes mídias - literatura, cinema e histórias em quadrinhos -, mas que, devido ao sucesso e difusão de suas narrativas, circulam muito bem entre elas: HARRY POTTER, nascido na literatura (Harry Potter and the philosopher's stone, 1997) e transportado recentemente para as telas de cinema e games; PETER PARKER (Spider-Man, 1969), que saiu das $H Q$ para os desenhos animados da televisão e para o cinema, além dos games, e LUKE SKYWALKER, nascido no cinema (Star Wars, 1977) e aproveitado pela literatura, animações, HQ e games. Ao compararmos as trajetórias desses três heróis, procuramos estabelecer alguns pontos de contato entre elas a partir do "arquétipo do órfão" que vem marcando presença constante na literatura infantil e juvenil.

Esta parece ser uma contribuição importante visto que, desde as narrativas mais antigas provenientes da oralidade até os dias de hoje, vários enredos cujos protagonistas são órfãos vêm conquistando crianças e jovens de todo o mundo em diferentes mídias.

Inúmeros contos, lendas e histórias das mais diversas proveniências e épocas trazem como protagonistas crianças órfãs ou enjeitadas. É o caso, por exemplo, de personagens bíblicas como Moisés; personagens lendárias como o Rei Arthur, ou os gêmeos Rômulo e Remo, fundadores de Roma; ou ainda personagens mitológicas como Páris e Perseu, que por motivos diversos foram afastadas de suas verdadeiras famílias.

Nos contos de fadas, por exemplo, não é raro o enredo em que a princesa órfã, geralmente criada - e maltratada - pela madrasta, enfrenta desafios e obstáculos para sobreviver e alcançar a almejada felicidade. Não 
menos usual é o caso do rapaz órfão que deixa o lar após a morte dos pais e deve superar diversas situações nas quais é obrigado a testar seus limites para atingir, por seus próprios méritos, a maturidade desejável de um herói.

Obras consagradas da literatura mundial, como Oliver Twist, Jane Eyre e David Copperfield, entre outras, costumam trazer de forma constante órfãos como protagonistas ${ }^{1}$. Clássicos da linha "didático-moralista" também fazem uso desse protótipo, como por exemplo os italianos Coração e As aventuras de Pinóquio ${ }^{3}$

No mais importante conjunto de obras da literatura infantil brasileira de vanguarda também há um conhecido exemplo de personagem órfã: a menina Narizinho, protagonista da série "O Sítio do Picapau Amarelo", criação de Monteiro Lobato. Em Reinações de Narizinho (1931), livro que introduz o leitor ao universo do Sítio, não há referências precisas sobre a sua orfandade na apresentação da personagem. Porém, na versão original do livro, publicada onze anos antes, intitulada $A$ menina do narizinho arrebitado (1920), Monteiro Lobato usa um discurso mais direto e a condição de órfã da personagem é explicitada logo nos primeiros parágrafos, durante a descrição da figura de Dona Benta:

A velha vive feliz e bem contente da vida, graças a uma netinha órfã de pae e mãe, que lá mora des'que nasceu ${ }^{4}$.

Outros autores brasileiros também abordaram o tema da orfandade em obras clássicas da nossa literatura, como José Lins do Rego, em Menino

\footnotetext{
${ }^{1}$ Esse tema será retomado no Capítulo 3 da dissertação, quando serão forncecidos outros dados a respeito das obras citadas.

${ }^{2}$ DE AMICIS, EDMONDO. Cuore (Itália, 1886).

${ }^{3}$ COLLODI, CARLO. Le avventure di Pinocchio (Itália, 1883).

${ }^{4}$ LOBATO, MONTEIRO. A menina do narizinho arrebitado. São Paulo, Monteiro Lobato, 1920, p. 3 [mantida a ortografia original].
} 
de Engenho (1932) e Doidinho (1933) e Jorge Amado, em Capitães da Areia (1937).

Ampliando os horizontes do nosso estudo para a literatura infantil e juvenil contemporânea mundial, temos atualmente um dos mais surpreendentes casos de sucesso literário universal: a série Harry Potter ${ }^{5}$, composta por seis livros até agora publicados ${ }^{6}$, que faz do protagonista - um bruxo órfão - uma das personagens mais conhecidas e queridas pelas crianças e adultos de hoje.

Embalada por esse fenômeno da série britânica, mais recentemente, outra coleção foi lançada no mercado, desta vez nos Estados Unidos: "Desventuras em série" ( $A$ series of unfortunate events) traz a saga de três irmãos órfãos ${ }^{7}$, e já soma até agora onze livros publicados e uma adaptação para o cinema (Desventuras em série, 2004), baseada nos três primeiros volumes.

Voltando as atenções para outras mídias, paralelas à literatura, também nas $\mathrm{HQ}$ não são raros os casos de personagens órfãs, a começar pelos super-heróis mais conhecidos, como Super-Homem, Batman, Fantasma, Homem-Aranha, Hulk, entre outros.

\footnotetext{
${ }^{5}$ ROWLING, J. K. Harry Potter e a pedra filosofal (1997); Harry Potter e a câmara secreta. (1998); Harry Potter e o prisioneiro de Azkaban (1999); Harry Potter e o cálice de fogo (2000); Harry Potter e a Ordem da Fênix (2003); Harry Potter e o enigma do príncipe (2005).

${ }^{6}$ A autora prometeu ao todo sete livros, um para cada ano de estudo do protagonista na Escola de Bruxaria Hogwarts.

${ }^{7}$ A coleção "Desventuras em Série" ("A series of unfortunate events"), do autor Lemony Snicket (pseudônimo de Daniel Handler) conta a história dos irmãos Baudelaire (Violet, Klaus e Sunny), que perderam seus pais, a casa e tudo o que possuíam num incêndio criminoso. A série teve onze volumes já editados nos Estados Unidos (são aguardados originalmente treze), sendo que o décimo segundo, ainda sem título definido, está prometido para outubro de 2005 . Em 2002, sete dos oito volumes publicados até então conseguiram manter-se simultaneamente na lista de infantis mais lidos do jornal The New York Times. No Brasil, a coleção está sendo lançada pela Companhia das Letras e foram publicados até o momento dez títulos: Mau começo, $A$ sala dos répteis, O lago das sanguessugas (2001), Serraria baixo-astral, Inferno no colégio interno (2002), O elevador Ersatz, A cidade sinistra dos corvos (2003), O hospital hostil, O espetáculo carnívoro, O escorregador de gelo (2004).
} 
Embora todos os super-heróis mostrem de alguma forma poderes sobrenaturais ou extra-humanos, cada um deles traz consigo o estigma do órfão, gerando conflitos e buscas permanentes pela própria identidade. Mesmo não constituindo grande novidade (a maioria dos super-heróis foi concebida nos anos $30-60$ do século $X X)^{8}$, a saga dos super-heróis tem sido alvo de constantes versões cinematográficas ${ }^{9}$, trazendo para a nova geração de crianças e jovens o resgate dessas aventuras, com os recursos da tecnologia digital moderna.

Dessa forma, também o cinema tem contribuído para a propagação de sagas e enredos que trazem protagonistas órfãos. Além das adaptações de HQ ou de romances ${ }^{10}$ que já trazem essas personagens em seu repertório, essa mídia conta ainda com criações e roteiros originais recentes que investem na temática da orfandade.

Uma das sagas mais conhecidas e fiéis à trajetória do herói solitário é Star Wars (Guerra nas Estrelas), do produtor de cinema George Lucas, cujo enredo acontece "há muito tempo, numa galáxia muito distante", expressão que nos remete automaticamente ao "era uma vez" dos contos de fadas. Na série completa desenvolvida por Lucas, composta por seis episódios ${ }^{11}$, há na verdade dois enredos engatilhados, em duas trilogias distintas contadas em

\footnotetext{
${ }^{8}$ Super-homem (1934); Fantasma (1936); Batman (1939); Hulk (1962); Homem-Aranha (1962).

${ }^{9}$ Filmes lançados nos últimos anos baseados nos heróis dos quadrinhos: Homem-Aranha - 0 filme (2002); Hulk (2003); Demolidor (2003); Homem-Aranha 2 (2004); Batman Begins (2005); Quarteto Fantástico (2005).

10 Alguns romances consagrados que abordam a temática do órfão ganharam adaptações recentes para o cinema: O jardim secreto (1993); Jane Eyre (1994); A Princesinha (1995); De volta ao Jardim Secreto (2004).

11 Star Wars (Guerra nas Estrelas) - Guerra nas Estrelas: uma nova esperança (1977); O Império Contra-Ataca (1980); O Retorno de Jedi (1983); Episódio I - A ameaça fantasma (1999) e Episódio II - O Ataque dos Clones (2002); Episódio III - A vingança dos Sith (2005).
} 
ordem inversa $^{12}$, que se completam no tempo e cujos protagonistas - em cada uma delas - são órfãos.

Devido ao grande repertório encontrado e às visíveis intersecções entre todas essas tramas, esta dissertação buscará investigar a relevância dessa temática desde os modelos encontrados nos contos populares e contos de fadas até as recentes versões realizadas para crianças e jovens do século XXI.

$12 \mathrm{O}$ projeto inicial de Guerra nas Estrelas era composto por nove filmes. Segundo George Lucas (em entrevista gravada disponível no DVD extra que faz parte do Box Star Wars Trilogia, EUA, 2004), na época da produção do primeiro longa-metragem (Star wars - $A$ new hope, EUA, 1977) não havia tecnologia disponível suficiente para criar digitalmente as imagens de batalhas, necessárias para os três primeiros filmes, tendo ele optado por iniciar a saga pelo Episódio IV. Somente catorze anos depois da estréia do Episódio VI, o último da primeira trilogia, é que foi posto em prática o projeto inicial com o lançamento do Episódio I A ameaça fantasma (The phantom menace, EUA, 1999). Assim, a história dos "Cavaleiros Jedi" é contada em ordem inversa: primeiro a história do filho, Luke Skywalker (que será objeto de nosso estudo); depois a história do pai, Anakin Skywalker. O projeto de nove longas já foi descartado pelo produtor; deste modo a saga deu-se por completa em maio de 2005, com o lançamento do Episódio III, última parte da segunda trilogia. 
CAPÍTULO 1 PERCURSO do ÓRFÃo NA LITERATURA - As ORIGENS 
Personagens órfãs estão presentes nos mais diversos textos literários espalhados pelo mundo. Desde as narrativas orais, o arquétipo do órfão é revisitado regularmente na construção de diferentes personagens, sendo mantida, porém, uma estrutura básica predominante, principalmente no que diz respeito à sua trajetória.

Este capítulo visa apresentar, ou simplesmente resgatar da poeira dos livros, os heróis solitários que pontuaram nossas primeiras leituras - os contos de fadas -, buscando reencontrar o despertar da literatura infantil e ratificar suas origens no conto popular.

Antes, porém, de tecer as primeiras considerações a respeito da personagem órfã presente em narrativas provenientes da oralidade, procuraremos formalizar o que - nesta dissertação - chamaremos de "conto popular" e "conto de fadas", uma vez que há uma série de controvérsias e diferentes pontos de vista na conceituação e na categorização dos contos, de maneira geral. 


\subsection{O órfão nas narrativas populares}

Wusiwana i ku yendza ka mamana. A verdadeira desgraça é a ausência da mãe.

(Provérbio moçambicano)

A cultura oral é a grande precursora da Literatura Infantil e Juvenil ${ }^{13}$. Os contos de fadas - as mais populares narrativas para crianças e jovens conhecidas em todo o mundo - nasceram de relatos orais recolhidos em diversos lugares, tendo sido sedimentados principalmente no século XVII pela publicação dos contos de Charles Perrault (1697) e, um pouco mais tarde, no século XIX, pela recolha dos Irmãos Grimm (1812) e pela obra de Hans Christian Andersen (1835) ${ }^{14}$.

Na América, além da cultura trazida pelos europeus a partir do século $\mathrm{XVI}$, muitos contos folclóricos tiveram uma outra fonte bastante remota: 0 Popol-Vuh - um texto primordial da literatura pré-colombiana, encontrado na Guatemala em meados do século XVI e escrito na linguagem k'iche $e^{15}-$, considerado por estudiosos como um dos documentos mais antigos que se conhece hoje sobre a história da humanidade ${ }^{16}$.

${ }^{13}$ SIMONSEN, M. O conto popular. São Paulo, Martins Fontes, 1987, pp. 15-20.

${ }^{14}$ COELHO, N. N. Panorama histórico da Literatura Infantil / Juvenil, 4. ed., São Paulo, Ática, 1991, pp. 84-198.

${ }^{15}$ O k'iche' ou "quiché" é uma língua arcaica da Guatemala derivada da linguagem maia que se falava durante o período chamado "Pós-Clássico" (de 900d.C. a 1492, data da chegada dos espanhóis a Cuba).

${ }^{16}$ Segundo Rafael Girard (GIRARD, R. El Popol-Vuh, fuente histórica. Min. de Ed. Pública, Guatemala, 1952), estima-se que o Popol-Vuh seja inclusive anterior ao Rig Veda dos hindus e ao Zend Aresta dos persas. Originalmente transmitido pela tradição oral, assim preservou-se na memória do povo ou em hieróglifos maias escondidos durante a colonização espanhola na região, e conseguiu "sobreviver" por duzentos anos à censura da Igreja, chegando aos nossos dias, graças a uma tradução espanhola realizada no século XVIII. Disponível em <http://www.uweb.ucsb.edu> Acessado em 04/10/2005. 
Assim como vários registros maias, muitos outros textos arcaicos seguramente foram destruídos - de modo proposital, para que os valores antigos não prevalecessem sobre os novos -, ou simplesmente se perderam no tempo, deixando apenas vestígios, rumores, indícios de que tenham um dia existido. Como pequenas peças de um gigantesco quebra-cabeça, às vezes os contos se encaixam, e então podemos ter uma vaga idéia de como se teria constituído um possível prototexto, e de como se deram seus desdobramentos.

$\mathrm{Na}$ verdade, muitos dos textos que existem hoje como clássicos infantis não nasceram para falar às crianças, mas compunham um repertório transmitido oralmente por incontáveis gerações em diferentes locais e épocas, tendo sofrido então um sem-número de versões, adaptações e recriações.

Nelly Novaes Coelho afirma de forma categórica ser descendente da tradição oral e da memória dos povos a "célula-mater" de toda a literatura infantil que atualmente conhecemos como "clássica":

Quando falamos hoje nos livros consagrados como clássicos infantis, os contos-de-fada ou contos maravilhosos de Perrault, Grimm ou Andersen, ou as fábulas de La Fontaine, praticamente esquecemos (ou ignoramos) que esses nomes não correspondem aos dos verdadeiros autores de tais narrativas. São eles alguns dos escritores que, desde o século XVII, interessados na literatura folclórica criada pelo povo de seus respectivos países, reuniram as estórias anônimas, que há séculos vinham sendo transmitidas oralmente, de geração para geração, e as transcreveram por escrito ${ }^{17}$.

Mais adiante, complementa seu argumento explicando a decorrência das narrativas primordiais orientais em narrativas medievais arcaicas, que por sua vez se popularizam na Europa e, conseqüentemente em suas colônias

\footnotetext{
${ }^{17}$ COELHO, N. N. Op. cit., p. 12.
} 
americanas, transformando-se, posteriormente, em literatura folclórica ou em literatura infantil ${ }^{18}$.

Também Lúcia Pimentel Góes compartilha dessa premissa, esclarecendo a diferença entre o nascimento da Literatura Infantil - nas longínquas narrativas primordiais - e o do livro infantil, que teria surgido "apenas quando se originou uma preocupação com a criança enquanto conceito burguês"19:

Poderíamos lembrar a reflexão de M. Iline, soviético que diz que o primeiro livro para os adultos tinha mãos e pés, e falava, era um livro vivo. O homem. Para o primeiro livro infantil podemos colocar o mesmo (...) Assim, situar as origens no Panchatantra, Perrault, Fénelon ou Júlio Verne dependerá da concepção que se tiver do livro infantil: uma história de animal, uma fábula, um conto maravilhoso, iniciação à ciência ou ao mundo real ${ }^{20}$.

Assim, uma vez que nosso objeto de estudo - a Literatura Infantil - é procedente da vasta literatura oral, iniciaremos nosso percurso por uma de suas mais férteis ramificações, aqui designada genericamente "conto popular".

\footnotetext{
${ }^{18}$ Idem, p. 13.

${ }^{19}$ GÓES, L. P. Introdução à Literatura Infantil. São Paulo, Pioneira, 1984, p. 55.

${ }^{20}$ Idem, p. 12.
} 


\subsubsection{Natureza do conto popular}

Antes de começarmos a delinear o protótipo do órfão presente nas narrativas populares, é necessário indicar em linhas gerais o que - neste trabalho - chamaremos de "conto popular", uma vez que existem diversas nomenclaturas para um mesmo tipo de literatura oral, e algumas definições esbarram em detalhes tão sutis que quase sempre acabam impossibilitando uma abordagem absolutamente precisa de quando um gênero termina e 0 outro começa.

André Jolles, em Formas Simples ${ }^{21}$, afirma que o conto "só adotou verdadeiramente o sentido de forma literária determinada no momento em que os Irmãos Grimm deram a uma coletânea de narrativas o título de Kinder-und Hausmärchen [Contos para crianças e famílias]", ratificando o estreito relacionamento entre conto popular e conto de fadas:

Ainda que eu corra o risco, evidentemente, de dar uma definição circular, poderia dizer que o Conto é uma narrativa da mesma espécie das que os irmãos Grimm reuniram em seus Kinder-und Hausmärchen (Contos para crianças e famílias). (...) É costume atribuir-se a uma produção literária a qualidade de Conto sempre que ela concorde mais ou menos (para usar deliberadamente uma expressão vaga) com o que se pode encontrar nos contos de Grimm².

Mais à frente, cita como propriedade do conto o fato de a ação localizar-se sempre "num país distante, longe, muito longe daqui" e "há muito, muito tempo". Justifica o uso desse artifício afirmando que uma localização histórica em um tempo histórico aproximaria o conto da realidade e quebraria o

\footnotetext{
${ }^{21}$ JOLLES, A. Formas Simples. São Paulo, Cultrix, 1930, p. 181.

${ }^{22}$ Idem, p. 182.
} 
"fascínio do maravilhoso natural e imprescindível"23. Acrescenta, por último, a singularidade de a maioria das personagens típicas dos contos ser desprovida de nome próprio ou de qualquer vestígio de ligação com a realidade. Assim, o "príncipe" é simplesmente o "príncipe", sem haver alusão a um determinado príncipe ou personagem histórica. À medida que essa personagem não tem qualquer relação com uma época ou local, passa a ser um ícone desvencilhado da realidade e da "verdade":

Se o príncipe do conto tivesse o nome de um príncipe da História, seríamos logo transportados da ética do acontecimento para a ética da ação. Já não perguntaríamos "Que acontece então ao príncipe?", mas "Que fez o príncipe?" e começar-se-ia a duvidar da necessidade das coisas ${ }^{24}$.

Nessa mesma linha, apresentando uma caracterização mais recente do conto, o estudioso da cultura popular brasileira, Câmara Cascudo, postula: "é preciso que o conto seja velho na memória do povo, anônimo em sua autoria, divulgado em seu conhecimento e persistente nos repertórios orais". E ainda "que seja omisso nos nomes próprios, localizações geográficas e datas fixadoras do caso no tempo"25.

Por conta dessa "ausência de autoria", o conto popular para alguns é resultado de uma "criação coletiva", sendo essa uma das justificativas para que exista uma série de variantes de um mesmo conto espalhadas pelos mais diversos pontos do mundo.

Esse fato também pode ser percebido nos contos de fadas, cujas versões em diferentes culturas apenas corroboram a existência de uma fonte comum, longínqua no tempo e no espaço, podendo possivelmente pressupor a

\footnotetext{
${ }^{23}$ Idem, p. 202.

24 Idem, pp. 202-203.

${ }^{25}$ CASCUDO, L. C. Contos tradicionais do Brasil. 11. ed., Rio de Janeiro, Ediouro, 1998.
} 
existência desse "inconsciente coletivo" que permeia todas as épocas e lugares. Em seu livro $O$ conto de fadas, Nelly Novaes Coelho afirma, ao especular sobre as fontes (orientais, célticas e européias) que teriam originado os contos:

Algo, porém, tornou-se evidente: teria havido um fundo comum a todas elas, pois de outra forma não se poderia explicar a coincidência de episódios, motivos etc., em contos pertencentes a regiões geograficamente tão distantes entre si e com culturas, línguas ou costumes absolutamente diferentes. ${ }^{26}$

Michèle Simonsen, autora de $O$ conto popular, inicia sua definição do gênero afirmando ser o conto aquele "que se diz e se transmite oralmente"27, fazendo parte, portanto, do "folclore verbal" e configurando um "relato", diferentemente de outros textos orais como os provérbios, adivinhas ou canções. Mais à frente, tentando estabelecer uma linha divisória entre o conto e os demais gêneros narrativos populares (entre eles o mito, a saga, a gesta, a lenda e a anedota), Simonsen indica ser este o único que estaria totalmente desvinculado da realidade, sendo um gênero ficcional puro, descomprometido com a "verdade", cuja função social seria o mero entretenimento ou diversão ${ }^{28}$.

Ricardo Azevedo, em sua dissertação de mestrado que abordou os vestígios do conto popular na literatura infantil e juvenil ${ }^{29}$, afirma que, "paradoxalmente, o conto afasta-se da realidade para meditar sobre ela" ${ }^{\text {. }}$ Utilizando as definições de Simonsen e Jolles, o autor constata que esse gênero remete-nos - necessariamente - à ficção.

\footnotetext{
${ }^{26}$ COELHO, N. N. O conto de fadas, São Paulo, Ática, 3. ed., 1998, p. 17.

${ }^{27}$ SIMONSEN, M. Op. cit., p. 5.

${ }^{28}$ Idem, p. 6

${ }^{29}$ AZEVEDO, R. Como o ar não tem cor se o céu é azul? Vestígios dos contos populares na Literatura Infantil. Dissertação [mestrado]. São Paulo, USP, 1997.

${ }^{30}$ Idem, p. 75.
} 
Assim, para ele, o conto "é sempre uma estória inventada, que não ocorreu mas poderia ter ocorrido, e que pretende divertir o ouvinte. (...) Em outras palavras, o fato de a obra literária abordar fatos que não ocorreram não impede que ela seja uma reflexão sobre a vida e o mundo (= "realidade")"31.

Tomando como ponto de partida essas definições de conto popular, podemos tentar estabelecer alguns paralelos entre a trajetória de personagens órfãs que figuram em alguns contos populares de diferentes origens e delinear um perfil comum entre elas.

${ }^{31}$ Idem, p. 72. 


\subsubsection{Percurso do órfão no conto popular}

No item de sua dissertação cujo tema é "conto e herói"32, Ricardo Azevedo recorda que, em boa parte dos contos populares, há "personagens que, saindo pelo mundo (= arriscando-se) voluntariamente ou não, passam por vivências, verdadeiras provas". Entre essas provas, ele elenca como principais:

1. o autoconhecimento (busca da própria identidade);

2. o encontro do parceiro amoroso (casamento);

3. a conquista de situação financeira estável (fortuna, poder).

No caso da personagem órfã, é muitas vezes a solidão ou a sensação de abandono que acentuam essas vivências. Quando se perdeu pai e mãe, a busca da própria identidade torna-se tarefa prioritária; a solidão e o desconforto podem ser aplacados no encontro amoroso; e a conquista de uma situação financeira favorável faz-se imprescindível para quem não tem um lar.

Para encerrar sua análise de "conto e herói", Ricardo Azevedo pontua:

Em resumo, pode-se dizer que os heróis de narrativas populares, em geral: 1) são paradigmáticos por princípio; 2) vivem em lugares genéricos, longe daqui, há muito tempo atrás; 3) muitas vezes são identificados apenas como o príncipe, o rei, a princesa, a bruxa etc. Mesmo quando nomeados, apresentam nomes comuns, João, Maria ou Pedro, nomes que qualquer um poderia ter; 4) nem sempre apresentam aspectos físicos determinados e substantivos, mas sim genéricos e adjetivos: são bonitos ou feios, fortes ou fracos, espertos ou tolos, bons ou maus, sortudos ou azarados (...); 5) estão envolvidos em aventuras que remetem a questões humanas bastante amplas: a busca do autoconhecimento (quantos heróis pedem a bênção do pai e, em seguida, partem para "conhecer o mundo"? Ou então, perseguidos, fogem de casa e vêem-se obrigados a enfrentar riscos e desafios? Ou ainda, sozinhos no mundo, após a morte do pai, partem em busca da sorte?) ${ }^{33}$. [grifo nosso]

\footnotetext{
${ }^{32}$ Idem, p. 101.

${ }^{33}$ Idem, p. 103.
} 
Ou seja, a orfandade, embora não seja característica obrigatória das personagens no conto popular, faz parte de um paradigma absolutamente necessário para impulsionar sua ação em diversos enredos.

Para que esse desencadeamento da ação a partir da orfandade do protagonista possa ser melhor evidenciado, serão apresentados a seguir os parágrafos ou trechos iniciais de dez contos populares ${ }^{34}$, retirados de sete diferentes coletâneas. Esta pequena amostragem poderá ser bastante útil para se tentar delinear o protótipo da personagem órfã presente em narrativas procedentes na oralidade:

I) O espelho mágico, recolha de Câmara Cascudo;

II) Almofadinha de ouro, recolha de Câmara Cascudo;

III) A gata borralheira, recontada por Viale Moutinho;

IV) A história de João, recontada por Henriqueta Lisboa;

v) As três casinhas, recolha de Italo Calvino;

vI) Os três órfãos, recolha de Italo Calvino;

VII) A madrasta, recolha de Teófilo Braga;

VIII) O sapatinho de cetim, recolha de Teófilo Braga;

IX) A princesa dos cabelos de oiro, recontada por Joaquim A. Ferreira;

x) O rapaz do Conho, recolha de Lourenço Rosário.

${ }^{34}$ Os contos serão apresentados na íntegra no Apêndice 1 desta dissertação. A referência completa sobre cada um deles estará nas páginas subseqüentes. 


\section{I) Recolha de Câmara Cascudo no Brasil, Rio Grande do Norte ${ }^{35}$}

\section{O ESPELHO MÁGICO}

O rapaz, órfão de pai e mãe, saiu pelo mundo para ganhar a vida. la por um caminho quando viu uma pedra tapando a boca de um formigueiro e as formigas lutando para arredá-la. O moço que tinha bom coração, abaixou-se e tirou a pedra com cuidado para não matar as formigas. Quando acabou, uma formiguinha falou: - Se você se encontrar em dificuldades, diga: "Valha-me rei das formigas".

Neste conto, logo de saída é indicada a situação do herói, a partir do que se desencadeia a ação. Como em grande parte dos contos populares, o herói aqui não tem nome e a narrativa segue da orfandade diretamente para os acontecimentos subseqüentes, ou seja, a ausência dos pais é o fator que promove a partida do "rapaz" "pelo mundo" para "ganhar a vida".

As "boas ações" praticadas pelo protagonista em prol dos animais que Ihe cruzam o caminho (formiga, carneiro, peixe e águia) proporcionam-lhe ajuda nas provas que virão, e o final feliz é marcado pelo casamento com uma rica princesa.

Podemos resumir a estrutura do conto no seguinte esquema:

$>$ orfandade

> partida do herói

> encontro com seres/ objetos mágicos

$>$ encontro com a princesa

$>$ provas

$>$ ajuda sobrenatural

$>$ final feliz

${ }^{35}$ CASCUDO, L. C. Op. cit., pp. 88-90. 


\title{
II) Recolha de Câmara Cascudo no Brasil, Rio Grande do Norte ${ }^{36}$
}

\begin{abstract}
ALMOFADINHA DE OURO
Era uma vez uma menina muito bonita e graciosa, filha única, e que teve a infelicidade de ficar órfã de mãe. Seu pai ainda ficou moço e casou novamente, com uma viúva que tinha uma filha, pondo-se mocinha e muito feia e orgulhosa. A madrasta, na presença do marido, tratava a enteada bem, mas como esse vivia viajando, vingava-se, obrigando-a a trabalhos pesados, como lavar roupa, limpar a estrebaria, o galinheiro, a casa inteira, etc. A mocinha começou a viver amargurada e sofrendo toda a espécie de privações e insultos. De tanto padecer, perdeu a paciência e achou que o remédio era fugir daquele purgatório.
\end{abstract}

Neste conto, há uma alusão ao conhecido Cinderela. A morte da mãe da protagonista faz entrar em cena a figura da madrasta ${ }^{37}$, que transforma a vida da órfã em um verdadeiro inferno. Neste caso, a solução encontrada pela moça é a fuga. Auxiliada pela "almofadinha de ouro", ela conseguirá conquistar o príncipe.

Bastante similar à anterior, a estrutura do conto segue o esquema:

$>$ orfandade

$>$ maus tratos

$>$ provas

> encontro com seres/ objetos mágicos

> partida da heroína (fuga)

> ajuda sobrenatural

> encontro com o príncipe

$>$ final feliz

\footnotetext{
${ }^{36}$ Idem, pp. 67-70.

${ }^{37}$ O Capítulo 2 desta dissertação abordará o tema das madrastas.
} 


\title{
III) Versão russa de "A Gata Borralheira" recontada por Viale Moutinho"
}

\begin{abstract}
A GATA BORRALHEIRA
Era uma vez uma menina pequenina, que já não tinha pai nem mãe. Ora uma família muito ruim encarregou-se de criá-la.

Quando estava crescida obrigaram-na a mourejar e a responder a todos por tudo. A patroa dela tinha três filhas. A mais velha chamava-se Um Olho, a do meio Dois-Olhos e a mais nova tinha o nome de Três-Olhos. Mas elas só sabiam estar à janela e a menina tinha de trabalhar pelas quatro, e ainda era maltratada.
\end{abstract}

Nesta outra versão de Cinderela, desta vez originária da Rússia, a menina órfã passa por maus tratos aplicados pela família que a adotou e é perseguida e maltratada pelas filhas da patroa. Pode ser observada, neste conto, uma fusão das narrativas Cinderela e Um-Olho, Dois-Olhos, Três-Olhos, ambas recolhidas pelos Irmãos Grimm na Alemanha. No final do enredo, a órfã casa-se com um fidalgo e deixa a família perversa que a criou.

Embora a trama seja bastante similar à do conto anterior, a estrutura é um pouco diferente uma vez que a partida da heroína ocorre apenas no final do conto:

$>$ orfandade

$>$ maus tratos

> encontro com seres/ objetos mágicos

$>$ provas

$>$ ajuda sobrenatural

$>$ encontro com o fidalgo

> partida da heroína (casamento)

> final feliz

\footnotetext{
${ }^{38}$ MOUTINHO, J. V. Contos populares russos. São Paulo, Landy, 2000, pp. 95-98.
} 


\section{IV) Conto popular recontado por Henriqueta Lisboa ${ }^{39}$}

\section{HISTÓRIA DE JOÃO}

Houve um homem que teve um filho chamado João; morrendo o pai, o filho herdou um gato, um cachorro, três braças de terra e três pés de bananeira. João deu o cachorro ao vizinho, vendeu as bananeiras e as terras, e comprou uma viola. Foi tocar no pastorador das ovelhas do rei; quando o pastor chegava, ele se escondia, e nunca o pastor podia ver quem tocava a viola.

Logo no início do conto, com a herança deixada pelo pai, tem-se a falsa idéia de que o filho ficara amparado; porém - como tantos outros protagonistas órfãos - não se contentando em ocupar o lugar deixado pelo pai, o rapaz procura se desfazer das coisas de valor e parte para o mundo com a sua viola para tentar uma melhor sorte.

Embora não haja a realização do herói por meio de um casamento como é bastante comum em contos desta natureza -, há a compensação financeira e social, quando João é nomeado, devido à sua astúcia, como "pastor das ovelhas do Rei". Também não há neste conto a ajuda sobrenatural, tão freqüente nos contos populares.

Podemos resumir a estrutura do conto no seguinte esquema:

> orfandade

> partida do herói

> provas (prisão do herói)

> final feliz (emprego no palácio do Rei)

\footnotetext{
${ }^{39}$ LISBOA, H. Literatura oral para a infância e a juventude. São Paulo, Peirópolis, 2002, pp.
} 123-124. 


\title{
v) Conto italiano recolhido em Mântua por Italo Calvino ${ }^{40}$
}

\begin{abstract}
AS TRÊS CASINHAS
Ao morrer, uma pobre mulher chamou as três filhas e falou assim: Minhas filhas, dentro em pouco estarei morta e vocês vão ficar sozinhas no mundo. Quando eu não estiver mais aqui, façam assim: procurem seus tios e peçam que construam uma casa para cada uma. Queiram-se bem. Adeus. - E expirou. As três moças saíram chorando.
\end{abstract}

Nesta fábula recolhida por Italo Calvino há o tema do conhecido conto Os Três Porquinhos, sendo que, nesta versão italiana, moças desempenham o papel dos porquinhos.

A morte da mãe desencadeia o processo da busca por um novo lar; cada uma das irmãs irá construir sua casa com um tipo de material: esteiras, madeira e ferro. Assim como na maior parte dos contos em que há três irmãos, e que somente um deles triunfa, apenas a última órfã deste conto sobreviverá ao lobo.

Podemos resumir a estrutura do conto no seguinte esquema:

$>$ orfandade

> partida das irmãs

$>$ provas

> fracasso das irmãs (morte)

> partida da heroína

> provas

> final feliz

${ }^{40}$ CALVINO, I. Fábulas italianas. São Paulo, Cia. das Letras, 2000, pp. 84-87. 


\section{vi) Conto italiano recolhido na região da Calábria por Italo Calvino ${ }^{41}$}

\section{OS TRÊS ÓRFÃOS}

Um homem com três filhos morreu de doença. Os três filhos se tornaram três órfãos. Certo dia o mais velho disse: - Irmãos, estou de partida. Vou em busca de fortuna. Chegou a uma cidade e começou a gritar pelas ruas:

- Quem me quer como empregado considere-me contratado!

Este é um dos inúmeros contos em que a morte do pai ocasiona a saída dos filhos à procura de melhores condições de vida. Neste conto há a recorrência do tema dos três filhos (desta vez, todos homens), que com a morte do pai partem - um a um - em busca de fortuna. Do mesmo modo que em As três casinhas, também desta vez apenas o mais novo triunfará.

Assim como na História de João, o final feliz do herói é marcado por sua estabilidade econômica. A ajuda que o órfão recebe não é explícita por meio de objetos, amuletos ou de seres mágicos, mas por meio da oração e da fé.

Podemos resumir a estrutura do conto no seguinte esquema:

> orfandade

> partida dos irmãos

> provas

> fracasso

> partida do herói

$>$ provas

> final feliz

\footnotetext{
${ }^{41}$ Idem, pp. 292-94.
} 


\title{
VII) Conto português recolhido na região do Porto por Teófilo Braga ${ }^{42}$
}

\begin{abstract}
A MADRASTA
Uma mulher tinha uma filha muito feia e uma enteada bonita como o Sol; com inveja tratava-a muito mal, e, quando as duas pequenas iam com uma vaquinha para o monte, à filha dava-lhe um cestinho com ovos cozidos, biscoitos e figos, e à enteada dava-lhe côdeas de broa bolorentas, e não passava algum dia sem lhe dar muita pancada.
\end{abstract}

Este conto português traz novamente a figura da madrasta como em Cinderela, tomando partido da filha e aplicando maus tratos à enteada.

Também estão presentes os temas da irmã boa e bonita versus irmã má e feia (como em Mãe Hilda, dos Grimm), e a ajuda sobrenatural (fada disfarçada em velha).

A estrutura do conto é um pouco diferente uma vez que a fada interfere na rotina da órfã invertendo os papéis filha/ enteada, aplacando o sofrimento da protagonista enquanto ela aguarda a chegada do príncipe:

$>$ orfandade

$>$ maus tratos

> encontro com seres/ objetos mágicos

> inversão de papéis (filha/ enteada)

$>$ encontro com o príncipe

> partida da heroína (casamento)

$>$ final feliz

\footnotetext{
${ }^{42}$ BRAGA, T. Contos tradicionais do povo português, Vol. I. 5. ed., Lisboa, Dom Quixote, 1999, pp. 119-20. Este conto pertence ao ciclo da "Gata Borralheira". Teófilo Braga acrescenta em suas notas que "a troca das crianças pelas fadas acha-se nos Contes populaires de la Grande Bretagne, p. 223, trad. Brueyre".
} 


\section{VIII) Conto português recolhido na região do Algarve por Teófilo Braga ${ }^{43}$}

\section{O SAPATINHO DE CETIM}

Era uma vez um homem viúvo e tinha uma filha; mandava-a à escola de uma mestra que a tratava muito bem e lhe dava sopinhas de mel. Quando a pequenita vinha para casa, pedia ao pai que se casasse com a mestra, porque ela era muito sua amiga. $O$ pai respondia: - Pois queres que case com a tua mestra? Mas olha que ela hoje te dá sopinhas de mel, e algum dia tas dará de fel.

Assim como o anterior, este conto também pertence ao ciclo da "Gata Borralheira". Assim como em Os três homenzinhos do bosque, dos Irmãos Grimm, é a órfã quem propõe ao pai um segundo casamento, não contando com a mudança de comportamento da antiga mestra. Também como no conto alemão, a menina é premiada por suas boas ações, recebendo presentes mágicos, enquanto a irmã ${ }^{44}$ é castigada.

Nesta versão, os maus tratos da madrasta para com a enteada se intensificam após a morte do pai da menina. A órfã passa então a contar com a ajuda sobrenatural para conseguir ir aos bailes e, como Cinderela, apresentase no final do conto como a dona do "sapatinho de cetim".

A estrutura do conto segue o seguinte esquema:

$>$ orfandade / maus tratos

> encontro com seres/ objetos mágicos

> encontro com o príncipe

> partida da heroína (casamento)

$>$ final feliz

\footnotetext{
${ }^{43}$ Idem, pp. 292-94. Nas notas, Teófilo Braga acrescenta referências a outras versões, entre elas a encontrada nos Contos Populares da llha de Córsega, de Frederico Ortoli, e outras provenientes do Arquipélago da Madeira e nos Contos Populares do Algarve. Comenta ainda o fato de a expressão "Gata Borralheira" já existir em uma frase proverbial citada por Jorge Ferreira de Vasconcellos, datada do século XVI.

${ }^{44}$ No conto em questão, depois do casamento com o pai da órfã, a mestra engravida e dá à luz uma menina, meia-irmã da protagonista. Já no conto alemão (Três homenzinhos no bosque), as meninas não têm qualquer parentesco. $O$ capítulo 2 desta dissertação abordará as relações entre o órfão e seus irmãos.
} 


\title{
IX) Conto português recolhido na região de Trás-os-Montes e Alto Douro por Joaquim Alves Ferreira ${ }^{45}$
}

\begin{abstract}
A PRINCESA DOS CABELOS DE OIRO
Era uma vez uma princesa muito linda que tinha longas tranças de oiro e era o enlevo de seus pais. Mas, um dia, a mãe faleceu e o pai voltou a casar-se com uma mulher muito má que não gostava dela e fazia tudo para a tornar infeliz.

O seu ódio aumentou, quando the nasceu uma filha. Então, conseguiu virar contra ela o próprio pai e, com o seu consentimento, mandou os criados arrastá-la para uma floresta. e abandoná-la, para ser comida pelas feras.
\end{abstract}

Neste conto da tradição portuguesa, além da orfandade da heroína seguida da entrada de uma madrasta no enredo, há a recorrência dos temas: abandono na floresta (como em Branca de Neve), abandono no deserto (como em Rapunzel) e o tema da moça enterrada viva (como em diversos contos da mesma natureza). Há ainda o encantamento do príncipe - aqui metamorfoseado em pavão - e o arrependimento paterno, como em João e Maria, seguido do perdão da protagonista.

É possível resumir a narrativa no seguinte esquema:

> orfandade

$>$ maus tratos/ abandono

$>$ encontro com o príncipe/ casamento

> saudades de casa

$>$ reencontro com o pai

$>$ final feliz

${ }^{45}$ FERREIRA, J. A. Literatura popular de Trás-os-Montes e Alto Douro. Vol. V. Minerva Trasmontana, Vila Real, s/d, pp. 239-40. 


\section{x) Conto africano recontado por Lourenço Rosário ${ }^{46}$}

\section{O RAPAZ DO CONHO}

Havia na povoação de Mopeia uma rapariga linda como a lua. Chegada a altura de casar vieram rapazes das redondezas, dos mais valentes e aguerridos pedir aos pais que os deixassem casar com a rapariga. Todos os rapazes foram incapazes de resolver os problemas que o pai da rapariga ia colocando a cada um. Na aldeia de Malulu vivia um pobre órfão, numa cabana abandonada. Tinha o corpo coberto de sarna, não comia nem bebia havia vários dias porque quando saía à rua os cães seguiam-no e lambiam-lhe o corpo. O nome desse rapaz era "Nziwaeka", que quer dizer "Sabe tudo". Um dia Nziwaeka ouviu contar as belezas da rapariga e soube das provas exigidas. "Eu vou tentar, talvez tenha sorte".

Este é o típico conto do órfão que sai pelo mundo para tentar melhor sorte. Nesta narrativa de origem africana, o herói desprezado consegue passar por provas e peripécias, contando sempre com ajuda de objetos, seres e palavras mágicas. Assim como nos contos $O$ espelho mágico e $O$ sapatinho de cetim, é a partir de uma boa ação que o órfão passa a obter ajuda.

Podemos encontrar ainda a presença de velhas que dão presentes mágicos e a recorrência das provas impostas por um rei que oferece em troca do sucesso do herói a mão de sua filha em casamento.

A estrutura do conto pode ser resumida no seguinte esquema:

$>$ orfandade

> partida do herói

> encontro com seres/ objetos mágicos

> provas/ ajuda sobrenatural

$>$ retorno triunfante/ final feliz

${ }^{46}$ ROSÁRIO, L. A narrativa africana de expressão oral. Luanda, Angolê, 1989, pp. 214-217. Em sua análise comparativa com outro conto, Rosário comenta o fato de haver a presença de diversas referências geográficas no conto, porém acredita que esse fato "não tem por objetivo garantir a verossimilhança da história contada, mas tão somente evidenciar a competência do contador em situar aquilo que conta numa realidade social atualizada" (Op. cit. p. 225). 
Por meio desta pequena amostragem de contos populares, cujos enredos se iniciam com a apresentação da orfandade do protagonista, podemos perceber basicamente dois processos que encaminham as tramas:

1) a morte dos pais impulsiona o órfão a partir em busca de novas terras, dinheiro ou trabalho ou

2) a morte dos pais (ou de apenas um dos progenitores) favorece uma situação que torna impraticável a vida do órfão naquele lugar, levando-o a partir (fuga ou expulsão).

André Jolles alerta para o fato de a forma do conto dispor uma combinação de incidentes e dados que "contrariem o nosso sentimento de acontecimento justo". Em suas palavras:

O conto escolhe, de preferência, os estados e os incidentes que contrariem o nosso sentimento de acontecimento justo; um moço recebe menos em herança que seus irmãos, é menor ou mais tolo do que os que o cercam; crianças são abandonadas por seus pais ou maltratadas por uma madrasta; o noivo é separado da sua verdadeira noiva; homens ficam sujeitos a espíritos malfazejos, são forçados a executar tarefas sobre-humanas, sofrem perseguições e têm de fugir; eis outras tantas injustiças que são invariavelmente abolidas no decurso dos acontecimentos e cujo desfecho satisfaz nosso sentimento de acontecimento justo ${ }^{47}$ [grifos nossos].

Assim, a partida do herói visará, antes de tudo, reparar essa "injustiça" caracterizada, no caso do herói órfão, pela sua própria condição de abandonado ou desvalido.

Retomando a idéia central desenvolvida por Ricardo Azevedo sobre conto e herói, pode-se dizer que a orfandade é um grande artifício para tornar "livre" o herói, favorecendo sua autonomia para que ele possa tomar as rédeas

${ }^{47}$ JOLLES, A., Op. cit., p. 201. 
de sua própria vida e construir sua trajetória. Talvez por isso o tema seja tão recorrente nas narrativas populares:

Como o herói, todos nós buscamos a felicidade; queremos conquistar o nosso amor (queremos ser amados); fugimos da dor física e da morte; procuramos a estabilidade financeira; enfrentamos duros desafios (o trabalho, 0 desemprego, a concorrência, a falta de amor próprio, certa doença. Um mau patrão ou um professor zangado, num dado instante, pode transformar-se em bruxas, dragões e precipícios); sabemos que a sorte pode mudar; gostamos de uma moça "tão bonita quanto as estrelas, os raios do sol e as flores perfumosas do campo". Em qualquer estágio da vida, com 7 ou 90 anos, a trajetória e a atuação dos heróis será sempre uma importante referência de vida. Concluindo, pode-se considerar o herói impessoal, genérico, alegórico mesmo, aquele com quem todos podem se identificar, descendente direto do herói mítico, um significativo substrato do conto popular ${ }^{48}$.

A partir desse substrato popular procuraremos seguir os passos da personagem órfã característica dos contos de fadas.

${ }^{48}$ AZEVEDO, R. Op. cit., pp. 103-4. 


\subsection{O órfão no conto de fadas}

A substância dos contos infantis não é produto de elucubrações pessoais e caprichosas, e sim o fundo do conhecimento dos homens.

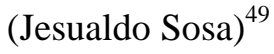

Há certa controvérsia entre os estudiosos na caracterização dos textos que conhecemos hoje como "contos de fadas". Assim, um breve histórico se faz necessário para situar essas narrativas no contexto em que foram primeiramente compiladas.

Segundo Nelly Novaes Coelho, embora "historicamente nascidos na França do século XVII (...) pela mão do erudito Charles Perrault, na verdade os conhecidos contos clássicos infantis têm suas origens em tempos bem mais recuados, e nasceram para falar aos adultos" ${ }^{\prime 50}$.

Segundo a autora, os vestígios mais antigos do que seriam as narrativas primordiais de cuja substância se originaram esses contos "remontam a séculos antes de Cristo e provêm de fontes orientais e célticas que, a partir a Idade Média, foram assimiladas por textos e fontes européias"

Não desprezando as fontes e as matrizes que originaram todas essas coletâneas, investigaremos neste capítulo, para fins deste trabalho, as narrativas compiladas primeiramente por Charles Perrault (1628-1703), pelos Irmãos Grimm - Jacob (1785-1863) e Wilhelm (1786-1859) - e também aquelas criadas ou recriadas por Hans Christian Andersen (1805-1875).

\footnotetext{
${ }^{49}$ SOSA, J. A literatura infantil. São Paulo, Cultrix, 1978, p. 135.

${ }^{50}$ COELHO, N. N. Op. cit., 1998, p. 16.

${ }^{51}$ Idem, pp. 16-17.
} 


\subsubsection{Natureza dos contos de fadas}

Segundo Nelly Novaes Coelho, Charles Perrault deixou de entrar para a história como poeta clássico (assim como ocorreu com o compatriota e contemporâneo Jean de La Fontaine) para ficar mundial e eternamente conhecido como "um dos maiores sucessos da literatura para a infância"52.

Em sua obra, intitulada Contes de ma Mère l'Oye ${ }^{53}$ (Contos da Mamãe Gansa), Perrault pela primeira vez torna públicas narrativas como $A$ Bela Adormecida no Bosque, Chapeuzinho Vermelho, O Gato de Botas e A Gata Borralheira, entre outras.

Esse gênero narrativo ficou conhecido na França como "contos de fadas" (conte de fées), nomenclatura usada até hoje para designar os contos maravilhosos em geral ${ }^{54}$, tendo alcançado enorme sucesso até o fim do século XVIII, quando a Revolução Francesa promoveu a abertura para uma nova maneira de pensar e agir, deixando as fadas e o "maravilhoso" apenas para o universo infantil e para a literatura oral, onde foram preservados ${ }^{55}$.

Em meados do século XIX, contudo, quando começaram a ser idealizados projetos de estudos filológicos e lingüísticos em vários países da Europa, a fim de se tentar desvendar os processos de transformação ocorridos nas línguas européias e contrastá-los com as línguas antigas, o interesse pelos contos populares de tradição oral voltou à tona. Entre esses países, a Alemanha abrigava um dos mais importantes centros de estudos, do qual participavam os irmãos Jacob e Wilhelm Grimm, filólogos e folcloristas,

\footnotetext{
${ }^{52}$ COELHO, N. N. Op. cit., 1991, p. 84.

${ }^{53}$ Idem, p. 68.

${ }^{54}$ Idem, p. 90.

${ }^{55}$ Idem, p.99.
} 
estudiosos da mitologia germânica, que se propuseram a resgatar as narrativas maravilhosas da memória do seu povo.

Pioneiros do nacionalismo alemão juntamente com outros escritores e intelectuais, os Irmãos Grimm ficaram conhecidos devido à grande coletânea de contos folclóricos que publicaram a partir de 1812 sob o título Kinder und Hausmärchen (Contos de fadas para crianças e adultos) ${ }^{56}$, constituindo uma tentativa de identificar e preservar o espírito original de um povo em um mundo em transformação.

Para recolher o material de seus contos, os irmãos viajaram pelo interior da Alemanha, fazendo um trabalho verdadeiramente "arqueológico". Por esse motivo, seus contos possuem a vitalidade de muitas gerações, porém há indícios de que apenas duas mulheres teriam sido sua principal fonte de consulta: uma velha camponesa de grande memória e uma amiga dos próprios Grimm, descendente de franceses ${ }^{57}$.

A partir do importante levantamento que fizeram, Jacob e Wilhelm Grimm revelaram o mundo mágico e maravilhoso da fantasia ao selecionar cerca de cem contos para reescrevê-los, utilizando vocabulário e estilo mais acessíveis ao público infantil. Entre seus textos mais difundidos estão Chapeuzinho Vermelho, A Bela Adormecida, A Gata Borralheira, Branca de Neve, Rapunzel, João e Maria e O Gato de Botas.

Quando comparamos os contos de Grimm com os compilados na França mais de um século antes por Perrault, há inúmeros indícios de que teriam tido uma fonte comum, tal a semelhança em seus enredos, nas

\footnotetext{
${ }^{56}$ Idem, pp. $140-8$.

57 Idem, ibidem.
} 
características das personagens e no bom humor existente nas narrativas presentes nessas coletâneas.

Também há uma certa equivalência em forma e conteúdo entre os contos de Grimm e aqueles recolhidos vinte anos mais tarde na literatura popular nórdica por Hans Christian Andersen. Estes últimos, no entanto, trazem uma estrutura própria, além de criações inéditas do próprio autor.

Influenciado pela exaltação da sensibilidade do período romântico, Andersen pretendeu que seus cerca de 160 contos, publicados entre 1835 e 1872 na coletânea Eventyr (Contos), fossem, acima de tudo, poéticos. Assim, foi conhecido por muito tempo como "o poeta das crianças", revelando-se como o primeiro grande criador da literatura infantil. Sua obra pode ser definida como uma volta às origens das narrativas preservadas pela memória popular, complementada por uma nova literatura que era então concebida. Entre suas narrativas mais conhecidas estão O Patinho Feio, O Soldadinho de Chumbo, Os cisnes selvagens, $A$ pequena vendedora de fósforos, As roupas novas do Imperador e A Pequena Sereia, entre outras.

No universo dos contos de Andersen não há apenas a leveza e o bom humor presentes nas obras de Grimm e Perrault. Incorporado com o pensamento racionalista romântico dos novos tempos, o "poeta das crianças" preocupou-se em apresentar em suas histórias um ar de tristeza ou dor, confrontando sempre o forte contra o fraco, o bonito contra o feio, o sadio contra o doente, tentando expressar em seus contos, dessa forma, a consciência cristã da igualdade de direitos, que proporcionariam um mundo mais justo e mais gratificante para os homens. 
Jesualdo Sosa aponta essa diferença com uma breve consideração:

A grande diferença entre as obras dos irmãos Grimm e as de Andersen está no fato de que os primeiros possuíam extrema sabedoria e habilidade no recolhimento e reprodução de experiências populares, enquanto o segundo tinha essas fontes populares em sua própria alma ${ }^{58}$.

Apesar disso, os contos de Grimm e de Andersen trazem como ponto comum o fato de estarem permeados de valores ideológicos românticos e ideais provenientes da mais remota idade, condensados em narrativas que contivessem algum ensinamento, algum sentimento, alguma razão de ser. A essas narrativas, somando-se aquelas compiladas décadas antes por Charles Perrault, muitos atribuíram, genericamente, a denominação "contos de fadas".

${ }^{58}$ SOSA, J. Op. cit., p. 133. 


\subsubsection{Conto de fadas $x$ conto maravilhoso}

Ao sugerir uma classificação para os contos populares, Michèle Simonsen alerta para o fato de o estudo dos contos populares apresentarem certas dificuldades de ordem terminológica, afirmando que "os folcloristas tendem a classificar os contos segundo critérios muitas vezes heterogêneos" ou acabam perdendo-se em subdivisões, uma vez que os termos consagrados pela tradição "são às vezes impróprios, e nem sempre coincidem de uma língua para a outra" ${ }^{59}$.

Assim, ao adotar a classificação sugerida pelo catálogo francês Delarue-Tenèze ${ }^{60}$, que aponta quatro subdivisões para os contos populares "propriamente ditos" ("contos maravilhosos, contos realistas, contos religiosos e histórias de ogros e estúpidos"), Simonsen atribui aos primeiros (contos maravilhosos) o mesmo significado de contos de fadas, definindo-os da seguinte maneira:

Contos maravilhosos, freqüentemente designados em francês pelo nome "conto de fadas", impróprio porque demasiado restrito, já que raramente se trata de fadas. Os contos maravilhosos, de estrutura complexa, comportam elementos sobrenaturais, originalmente nãocristãos (encantadores, metamorfoses, objetos mágicos, etc.). Os contos maravilhosos, aos quais tende-se às vezes a incorporar todos os contos populares, na realidade constituem apenas uma pequena parte do repertório ${ }^{61}$.

${ }^{59}$ SIMONSEN, M. Op. cit., p. 7.

${ }^{60} \mathrm{O}$ catálogo francês Delarue-Tenèze (DELARUE, P. E TENÈZE, M. L. Le conte populaire français. Catalogue raisonnè des versions de France et des pays de langue française d'outremer, 3 vol., Paris, Maisonneuve-Larose, 1957 APUD SIMONSEN, Michèle, Op. cit. p. 7) por sua vez segue o uso estabelecido pelo catálogo universal Aarne-Thompson (AARNE, A., THOMPSOU, S. The types of the Folktale. Helsinque, 1961 APUD SIMONSEN, Michèle, Op. cit. p. 7).

${ }^{61}$ SIMONSEN, M. Op. cit., p. 7. 
Já Nelly Novaes Coelho discorda da equivalência entre conto de fadas e conto maravilhoso, aos quais atribui naturezas, estruturas e problemáticas bem distintas:

Desse imenso caudal narrativo (hoje transformado ou simplificado em literatura folclórica ou literatura infantil), duas formas destacamse, não só pela divulgação que alcançaram através dos séculos, mas principalmente pela identificação feita entre uma e outra, como se ambas tivessem a mesma natureza. O que não é verdade. Trata-se do conto de fadas e do conto maravilhoso, formas de narrativa maravilhosa surgidas de fontes bem distintas, dando expressão a problemáticas bem diferentes, mas que, pelo fato de pertencerem ao mundo do maravilhoso, acabaram identificadas entre si como formas iguais $^{62}$.

Em sua análise, a autora nos aponta, assim como Simonsen, o problema da tradução para diferentes línguas e da dificuldade no uso de uma terminologia mais unificada:

Como sabemos, essas duas denominações [conto de fadas e conto maravilhoso] vêm sendo utilizadas, indistintamente, para rotular os milhares de narrativas que constituem o acervo da chamada Literatura Infantil Clássica (Chapeuzinho Vermelho, Branca de Neve, $O$ Pequeno Polegar etc. etc.). Na França, a denominação é conte de fées; na Inglaterra, fairy tale; na Espanha, cuento de hadas; na Itália, racconto di fata; na Alemanha, märchen (fábula popular, história fantasiosa, não-verdadeira, substituindo, a partir dos Grimm, a forma feenmärchen, usada no século XVIII). Em Portugal e no Brasil, surgiram, no fim do século XIX, como contos da carochinha. Câmara Cascudo chama-as de contos de encantamento. Mas a verdade é que hoje são vulgarmente conhecidas como contos de fadas ou contos maravilhosos, sem nenhuma distinção entre as duas formas ${ }^{63}$.

Para a autora, existe, sim, uma diferenciação básica entre conto maravilhoso e conto de fadas: contos maravilhosos teriam como eixo gerador uma "problemática social", focada diretamente à vida prática e concreta e ao desejo de auto-realização do herói, principalmente no aspecto socioeconômico, por meio de ascensão social, acúmulo de bens, um bom casamento e um

\footnotetext{
${ }^{62}$ COELHO, N. N. Op. cit., 1998, p. 11.

${ }^{63}$ Idem, p. 12.
} 
conforto financeiro; já os contos de fadas teriam como ponto de partida uma “problemática existencial”, voltada a uma satisfação interior, seja a busca pela própria identidade ou a descoberta de um grande amor, nas palavras da autora, "a realização essencial do herói ou da heroína"64.

Além dessa diferenciação quanto à problemática, Nelly Novaes Coelho aponta outra divergência interessante a respeito da origem do conto maravilhoso e do conto de fadas: enquanto o primeiro gênero se teria originado das narrativas orientais, enfatizando o lado material, sensorial e ético do ser humano, o último seria de origem celta, abordando uma perspectiva mais idealista, tendo como base de seus enredos a luta pelos valores humanos.

Sem entrar no mérito dessa distinção, adotaremos nesta dissertação a caracterização básica proposta por Jesualdo Sosa, que resumimos em linhas gerais a seguir.

Em primeiro lugar, deve haver na narrativa a presença do maravilhoso, que Ihe atribui um "caráter imaginativo",65, fazendo uma analogia do conto de fadas ao "faz-de-conta" típico da infância. Como no conto popular, o meio em que a ação se desenrola geralmente é impreciso e vago, assim como a situação no tempo ("era uma vez"). As ações desenvolvidas pelas personagens devem manter acesa a chama da imaginação, enquanto a motivação que gera essas ações é geralmente simples, com resultados rápidos e imediatos. Desse modo as personagens podem triunfar sem muito esforço, como se estivessem vivendo um sonho ${ }^{66}$.

\footnotetext{
64 Idem, p. 13.

65 SOSA, J. Op. cit., p. 122.

${ }^{66}$ Idem, p. 126.
} 
Com relação às personagens, a estrutura do conto de fadas costuma seguir sempre certos critérios: poucas personagens, geralmente jovens na idade de se casar (raramente também crianças ou animais), com perfis psicológicos sempre extremos ("uma qualidade relevante elevada ao máximo"67). As personagens devem ser provenientes de um ambiente em que impera a máxima pobreza ou, pelo contrário, de um reino muito rico, de um palácio esplendoroso ou encantado.

Entre os coadjuvantes é comum o conto apresentar tipos similares, entre eles os irmãos do protagonista, madrastas, pais, inimigos, animais falantes ou objetos animados, cujas características personificam a característica predominante, como o orgulho, a bondade, a inveja, o ciúme, a beleza, entre outras. Ou seja, a grande maioria das personagens dos contos de fadas é na verdade formada por "arquétipos humanos".

Nas palavras de Italo Calvino, os contos de fadas ${ }^{68}$

são presos todos juntos, na sua sempre repetida e variada casuística de vivências humanas, uma explicação geral da vida, nascida em tempos remotos e alimentada no lento ruminar da consciência camponesa até os dias de hoje; são o catálogo dos destinos que podem ser atribuídos a um homem e a uma mulher, sobretudo pela parte da vida que de fato se faz um destino: a juventude, do nascimento (...) ao afastamento de casa, às provas para tornar-se adulto e então maduro, para confirmar-se como ser humano ${ }^{69}$.

${ }^{67}$ BÜHLER, C. El desarollo espiritual del niño. Madri, 1934, pp. 324-6 APUD SOSA, J. Op. cit., p. 124.

${ }^{68}$ Em seu livro intitulado Fábulas Italianas (Fiabe italiane), Italo Calvino apresenta uma seleção de mais de cem contos populares recolhidos em vários povoados e vilarejos da Itália. Por esse trabalho, Calvino chega a autodenominar-se um "Grimm italiano". Na língua italiana, o termo "fiaba" aproxima-se mais ao contexto do conto (popular, maravilhoso ou de fadas) do que a tradução "fábula", geralmente mais associada em português ao repertório de Esopo e La Fontaine.

${ }^{69}$ CALVINO, I. Sulla fiaba. Milão, Mondadori, 1996, pp. 38-9 [“(Le fiabe) sono prese tutte insieme, nella loro sempre ripetuta e sempre varia casistica di vicende umane, uma speigazione generale della vita, nata in tempi remoti e serbata nel lento ruminio delle coscienze contadine fino a noi; sono il catalogo dei destini che possono darsi a un uomo e a una donna, soprattutto per la parte di vita che appunto è farsi d'un destino: la giovinezza, dalla nascita (...) al distacco dalla casa, alle prove per diventare adulto e poi maturo, per confermarsi come essere umano"]. 


\subsubsection{Percurso do órfão nos contos de fadas}

Assim como no conto popular, a personagem órfã é um tipo bastante recorrente nos contos de fadas. Desse modo também não são raros os enredos de contos de fadas que têm início com a morte dos pais (ou de apenas um dos genitores) do protagonista, sendo essa a causa que desencadeia toda a ação.

Essa é, por exemplo, a fórmula utilizada no conhecido conto $O$ Gato de Botas. Após a morte do pai, o filho mais moço do moleiro herda o gato que Ihe fará companhia no decorrer da trama:

Era uma vez um moleiro que, ao morrer, deixou como herança para os seus três filhos todos os seus bens, que consistiam em um moinho, um burro e um gato. A divisão logo foi feita (...) e o pobre do caçula teve de se contentar com o gato $(\ldots)^{70}$.

Vladimir Propp, em As raízes históricas do conto maravilhoso, afirma que a estrutura do conto está delineada por uma "tranqüilidade épica" abalada logo no início por uma "desgraça":

Digamos apenas que a família vive feliz e tranqüila, e que assim poderia continuar por muito tempo se não ocorressem episódios quase imperceptíveis que de súbito, de forma absolutamente inesperada, degeneram em catástrofe. Às vezes tais acontecimentos têm início quando um adulto se afasta $(\ldots)^{71}$.

O afastamento dos adultos deixa as crianças e os jovens à mercê do destino e dos acontecimentos que virão a seguir, marcando de forma decisiva a

${ }^{70}$ GRIMM, J. \& GRIMM, W. Contos de Grimm. Trad. David Jardim Júnior. Belo Horizonte, Itaitaia, 2000, p. 462.

${ }^{71}$ PROPP, Vladimir. As raízes históricas do conto maravilhoso. 2. ed. Trad. Rosemary Costhek Abílio e Paulo Bezerra. São Paulo, Martins Fontes, 2002, p. 29. 
trajetória do herói ou da heroína do conto. Propp acrescenta que esse afastamento é necessário para criar "o terreno propício para a irrupção da desgraça"72. Complementa, ainda, afirmando que "uma forma mais acentuada de afastamento consiste na morte dos pais"73.

Mais à frente, dando continuidade às suas considerações estruturais sobre o início do conto maravilhoso, Propp discorre sobre a partida do herói:

...uma desgraça aconteceu. A progressão da ação exige que o herói, de uma forma ou de outra, fique sabendo disso (...) A maneira como o herói é informado da desgraça que ocorreu pouco importa para nosso propósito. Basta dizer que ele ficou sabendo e que se põe a caminho ${ }^{74}$.

Para Propp, a partida do herói, em si, nada tem de especial. Geralmente não são dados detalhes de como ocorre, tampouco são feitas outras tantas considerações que poderiam enriquecer a narrativa. O herói simplesmente parte, e é esse movimento de partir que interessa ao conto. Em suas palavras, "a composição do conto é armada sobre o deslocamento do herói no espaço"75.

Bruno Bettelheim, em uma análise não literária, mas psicológica (ou psicanalítica) dos contos de fadas, afirma que a partida do herói órfão é o caminho para que ele encontre não só sua identidade, mas seu lugar no mundo, e possa usar essa descoberta para novas conquistas. Ratifica essa teoria afirmando que "os contos de fadas lidam, de forma literária, com os problemas básicos da vida, especialmente os inerentes à luta pela aquisição da

\footnotetext{
72 Idem, p. 30.

73 Idem, ibidem.

74 Idem, p. 29.

75 Idem, p. 43.
} 
maturidade"76:

Muitas estórias de fadas começam com a morte da mãe ou do pai; nestes contos a morte do progenitor cria os problemas mais angustiantes, como isto (ou o medo disto) ocorre na vida real. ${ }^{77}$

$(\ldots)$

Só partindo para o mundo é que o herói dos contos de fada (a criança) pode se encontrar; e fazendo-o, encontrará também o outro com quem será capaz de viver feliz para sempre; isto é, sem nunca mais ter de experimentar a ansiedade de separação. ${ }^{78}$

Essa partida do órfão é na verdade o início de uma jornada de muitas aventuras e perigos, que somente terminará quando o herói alcançar aquilo que mais deseja. No caso do órfão, mais especificamente, esse desejo pode ser desde a satisfação pelo retorno ao lar, o encontro de si mesmo ou a descoberta do aconchego e aceitação em outro local, ou a própria realização por meio do casamento.

Assim como no conto popular, o percurso do órfão dos contos de fadas - como também o de grande parte dos heróis, em geral - é quase sempre estruturado em três etapas:

1) a partida rumo ao desconhecido;

2) a apresentação e a superação de obstáculos e

3) a volta para a casa ou o triunfo.

\footnotetext{
${ }^{76}$ BETTELHEIM, B. A psicanálise dos contos de fadas. 15. ed. Trad. Arlene Caetano. São Paulo, Paz e Terra, 1980, p. 221.

${ }^{77}$ Idem, p. 15.

${ }^{78}$ Idem, p. 19.
} 
Joseph Campbell denomina esses três momentos respectivamente como partida, iniciação e retorno ${ }^{79}$.

A partida pode ser desencadeada por diversos fatores, entre eles a busca de um espaço novo para viver ou a rejeição familiar. No caso de personagens órfãs, a própria orfandade é, muitas vezes, o motivo que leva o herói a partir.

A iniciação compreende provas ou obstáculos a serem superados geralmente distribuídos em uma escala gradativa crescente de dificuldade à medida que o herói avança, ou ainda seguem um esquema pré-definido de repetição - abrangendo diversas naturezas: física, psicológica, social, ideológica etc.

O retorno é caracterizado pelo final do seu percurso, que pode ser marcado pela conquista do objetivo traçado ou mesmo a volta ao lar.

Quando o protagonista do conto é uma moça ou princesa, porém, a partida geralmente não se dá de forma espontânea como no caso do rapaz, mas as circunstâncias criadas pela ausência da mãe (e/ ou do pai) tornam inviável sua vida naquele lar, tendo como decorrência sua fuga ou expulsão.

Ainda comentando sobre 0 início do conto, Propp analisa 0 confinamento das jovens em altas torres ou em esconderijos subterrâneos ${ }^{80}$. Mais suscetíveis a esse tipo de tratamento do que as personagens masculinas, as heroínas órfãs muitas vezes são maltratadas, presas, confinadas, o que acaba gerando fortes motivos para a sua partida, seja ela espontânea ou forçada.

\footnotetext{
${ }^{79}$ CAMPBELL, J. O herói de mil faces. 7.ed. Trad. Adail Ubirajara Sobral. São Paulo, Cultrix, 2002, pp. 59-247.

${ }^{80}$ PROPP, V. Op. cit., pp. 35-38.
} 
Nelly Novaes Coelho afirma que é possível encontrar o tema da partida da heroína nos contos nórdicos e eslavos e cita como exemplo o conto russo $A$ pena do Finist-Fier Falcão ${ }^{81}$, porém explica por que essa fórmula não vingou na maioria dos contos de fadas:

Compreende-se que esse esquema da busca feminina tenha desaparecido dos contos de fadas, assimilados pelo espírito cristão (como os que circulam entre nós, via Grimm, Perrault e Andersen), pois contraria a idealização da mulher, que está na base da civilização cristã ${ }^{82}$.

Ainda assim é possível encontrar a partida da heroína sob o tema da "donzela guerreira" em diversas fontes, tanto ocidentais - como por exemplo a encontrada no Romanceiro Geral, de Teófilo Braga, "Donzela que vai à Guerra"83, e suas inúmeras versões - quanto orientais, como no poema chinês Mu-lan (autor anônimo, século $\mathrm{V}$ ou VI d.C.) ou no conto russo Vasilisa, a bela ${ }^{84}$. Perspicácia, bravura e coragem são as características primordiais dessas protagonistas que invariavelmente tomam o lugar do homem (inclusive nas vestimentas e modos de agir) para sair em defesa da família na falta dos pais - geralmente anciãos ou debilitados - ou de irmãos mais velhos.

Um estudo mais detalhado de personagens órfãs femininas nos contos de fadas será realizado no Capítulo 2 desta dissertação, quando serão abordados os temas das madrastas e irmãs ciumentas, além dos outros desvios e atalhos que se abrirão na trajetória solitária da personagem órfã.

${ }^{81}$ AFANASIEV, A. (ORG). "Tale of the feather of Finist, the bright Falcon" IN: Russian Fairy Tales. Literatura Publishers, Moscou, 1998.

${ }^{82}$ COELHO, N. N. Op. cit., 1998, p. 11.

${ }^{83}$ GÓES, L. P. Em busca da Matriz. Contribuição para uma História da Literatura Infantil e Juvenil Portuguesa. São Paulo, Cliper, 1999, p. 197.

${ }^{84}$ AFANASIEV, A. (ORG). "Vasilisa, the beautiful" IN: Russian Fairy Tales. Literatura Publishers, Moscou, 1998. 
CApítulo 2

As PEdRas do CAMINHO: DESVIOS E ATALHOS NA TRAJETÓRIA dO ÓRFÃO 
Os feitos de um herói somente possuem real valor quando as provações e privações pelas quais ele deve passar forem significativas e consistentes o bastante para atestar de modo categórico seu heroísmo.

A ausência dos pais é sem dúvida o primeiro grande percalço que a personagem órfã terá de superar em sua trajetória. Sem o elo que o une primordialmente à sociedade, o órfão perde o referencial que tinha para sobreviver e vê-se obrigado a reformular seu modo de vida, muitas vezes de maneira precoce, para tentar superar as dificuldades que se interpõem em seu caminho. Entre essas dificuldades está o abandono do lar e a conseqüente partida rumo ao desconhecido.

Segundo Joseph Campbell ${ }^{85}$, o tema do exílio nos contos populares e folclóricos é muitas vezes apoiado no tema do desprezado ou desvalido, em que o órfão figura lado a lado com outros discriminados, como o enteado, 0 filho mais novo, o "patinho feio", o tolo, entre outros. De acordo com o autor, encontrando empecilhos grandes demais para se manter onde está (em um suposto lar), o "discriminado" é impelido a partir rumo às "trevas inexploradas" e, nessa caminhada, certamente entrará em contato com "presenças insuspeitadas, benignas ou malignas: um anjo, um animal solícito, um pescador, um caçador, uma anciã ou um camponês" ${ }^{\prime 86}$.

\footnotetext{
${ }^{85}$ CAMPBELL, J. Op. cit., p. 316.

${ }^{86}$ Idem, ibidem.
} 
Andrè Jolles lembra, durante sua descrição das características do conto, a presença de seres maravilhosos que cruzam o caminho do herói, seja "para o bem" ou "para o mal":

refiro-me às fadas e também aos monstros, ogres e bruxas que são sua contrapartida. Todos esses seres são o produto bem claro da disposição mental cujas duas direções encarnam. Monstros, espíritos malignos, ogres e bruxas encarnam a direção trágica; graças a seus poderes mágicos, as boas fadas e tudo o que a elas se associa são o meio mais seguro de escapar à realidade ${ }^{87}$.

É geralmente a partir desses encontros que o herói solitário passa a interagir com o desconhecido e inicia seu verdadeiro aprendizado sobre 0 mundo que o cerca, buscando superar as inevitáveis adversidades por que passará, tentando diferenciar falsos de bons amigos e começando a compreender que, em seu caminho, haverá sempre desvios e atalhos, cabendo a ele - e somente a ele - decidir que rumo tomar.

Neste capítulo abordaremos os desvios e atalhos encontrados de forma mais sistemática na trajetória de personagens órfãs, partindo do conto popular e dos contos de fadas, e procurando alcançar os dias de hoje.

${ }^{87}$ JOLLES, A. Op. cit., p. 203. 


\subsection{Desvios: a perversidade, o ciúme e a maldade no caminho do órfão}

A partida original para a terra das provas representou, tão-somente, o início da trilha, longa e verdadeiramente perigosa, das conquistas da iniciação e dos momentos de iluminação. $(\text { Joseph Campbell) })^{88}$

O primeiro desvio a ser contornado pela personagem órfã em sua trajetória é a desestruturação de seu ambiente familiar. Seja pela ausência do pai, da mãe ou de ambos, o órfão sofrerá com a sensação de abandono, tornando-se vulnerável para o aparecimento de outros sentimentos, como a rejeição, a melancolia, o desespero, a frustração, o medo, a solidão...

Madrastas invejosas, irmãos ciumentos e falsos amigos aproveitadores são apenas alguns entraves do caminho tortuoso por onde o órfão terá de seguir. Mais adiante haverá ainda outros, como provas a serem vencidas, obstáculos, trapaças e armadilhas. Tudo isso, porém, faz parte do destino de um herói, sobretudo de um herói solitário, como é o caso do órfão.

Em suas considerações sobre os contos de fadas, Nelly Novaes Coelho acredita serem esses obstáculos os responsáveis pela realização existencial do herói:

A efabulação básica do conto de fadas expressa os obstáculos ou provas que precisam ser vencidas, como um verdadeiro ritual iniciático, para que o herói alcance sua auto-realização existencial, seja pelo encontro de seu verdadeiro eu, seja pelo encontro da princesa, que encarna o ideal a ser alcançado ${ }^{89}$.

\footnotetext{
${ }^{88}$ CAMPBELL, J. Op. cit., p. 110.

${ }^{89}$ COELHO, N. N. Op. cit., 1998, p. 13.
} 
Como os primeiros empecilhos na trajetória do órfão muitas vezes estão dentro de sua própria casa, começaremos a delinear os desvios em seu caminho por meio do estudo de uma das figuras mais presentes como vilãs de contos infantis: a madrasta. 


\subsubsection{A figura da madrasta}

Uma das maneiras de se contornar a ausência da mãe na vida de uma criança é colocar uma outra pessoa em seu lugar. Essa "substituição" no entanto nem sempre é bem aceita ou bem-vinda. A segunda esposa vem para "roubar" o lugar da mãe, sendo muitas vezes rejeitada antes mesmo de praticar qualquer ação. Nos contos infantis, porém, o que se tem normalmente é a rejeição inversa: é a madrasta quem costuma renegar os filhos do primeiro casamento do marido, infernizando a vida dos órfãos.

Essa complexa relação entre madrastas e enteados é bem abordada por Ana Cristina Gonçalves em seu livro Madrastas - do conto de fadas para a vida real, em que a autora reserva um capítulo exclusivamente para discorrer sobre a figura da madrasta nos contos de fadas:

Nenhuma coletânea de histórias dá tanta importância às madrastas quanto os contos de fadas. Foram eles a grande manifestação social que revelaram as polaridades, as ambigüidades e os estigmas sociais. Como as bruxas, as madrastas são as responsáveis por todo o sofrimento moral, emocional e físico dos heróis e heroínas dos contos de fadas ${ }^{90}$.

Um pouco adiante, referindo-se mais à vida real do que aos contos, a autora complementa:

O falecimento de uma das figuras parentais é uma experiência dolorosa para as crianças. Pai e mãe são figuras importantes no desenvolvimento infantil e a ausência de uma delas é sentida pela criança como perder parte de si mesma.

${ }^{90}$ GONÇALVES, A. C. C. Madrastas: do conto de fadas para o mundo real. São Paulo, Iglu, 1998, p. 35. 
A figura da mãe é tão importante para a criança que, quando esta vem a falecer, a criança procura ansiosamente substituí-la. Isso é tão verdadeiro que, mesmo crianças que convivem com a mãe, mas que por diversas razões não conseguem estabelecer um vínculo afetivo com elas, projetam nas figuras substitutas femininas esta mãe faltante, esperando delas que the adotem como filhos ${ }^{91}$.

No entanto, por mais que a presença de uma mãe substituta seja importante para a criança, a madrasta desponta como a grande vilã da literatura infantil e juvenil, sendo sempre lembrada por seu ciúme, sua inveja, perversidade e negligência para com os enteados. Uma prova disso é o fato de dois dos contos de fadas mais conhecidos em todo o mundo - Cinderela e Branca de Neve - trazerem essa personagem como antagonista e responsável direta pelas amarguras sofridas pelas heroínas no decorrer dos respectivos enredos. Em ambos os casos, a simples presença da madrasta na trama acaba intensificando o apelo à jovem órfã, que, desprotegida, naturalmente já teria a cumplicidade do leitor:

A orfandade é talvez o maior receio do ser humano. Histórias tristes estão sempre ligadas à separação, seja concreta, seja simbólica, mas sempre à separação. Um órfão é sempre uma figura que mobiliza os sentimentos das pessoas, são dignos de sua pena, dó e ajuda incondicional. Talvez por isso "Cinderela" tenha tido uma repercussão fantástica. Ela é a personificação da orfandade, do abandono e do sofrimento humano ${ }^{92}$.

Marina Warner, autora de Da fera à loira - sobre contos de fadas e seus narradores ${ }^{93}$, no capítulo dedicado às mães ausentes ${ }^{94}$, afirma que, "em todo mundo, histórias centradas em uma heroína, uma jovem que sofre uma

\footnotetext{
${ }^{91}$ Idem, pp. 84-5.

92 Idem, p. 85

${ }^{93}$ WARNER, M. Da fera à loira - sobre contos de fadas e seus narradores. Trad. Thelma Médici Nóbrega. São Paulo, Companhia das Letras, 1999.

${ }^{94}$ Idem, pp. 233-250.
} 
longa provação antes da sua redenção e triunfo, freqüentemente escalam mulheres como as agentes de seu sofrimento"95.

No capítulo seguinte, destinado exclusivamente às madrastas ${ }^{96}$, a autora faz uma comparação entre a figura da madrasta e a da sogra, lembrando inclusive que, na língua francesa, ambas são designadas pela mesma palavra: belle-mère. Segundo Warner, "a madrasta perversa, que se tornou a figura mais corriqueira dos contos de fadas, fez sua primeira aparição literária como sogra no conto 'Eros e Psiquê', de Apuleio"97.

O conto a que se refere - na verdade um mito encaixado no romance $O$ asno de ouro $^{98}$ (século II d.C.) - traz uma série de características que aparecerão mais tarde em diversos contos populares, contos de fadas e narrativas contemporâneas, tais como o fato de a protagonista ser a mais nova e a mais bela entre três irmãs, de o pai prometê-la a um noivo desconhecido e de o noivo ser um homem muito belo apesar de todos acreditarem tratar-se de um monstro. Há ainda a recorrência das "irmãs invejosas"; das "provas" impostas para se redimir um erro; da "ajuda sobrenatural"; da "união amorosa entre seres teoricamente bastante diferentes", etc. Além disso, apesar de a protagonista do mito - Psiquê - não ter como tutora uma madrasta propriamente dita, acaba por passar por provas bastante semelhantes às de Cinderela, impostas neste caso pela sogra - Vênus.

Um exemplo bem claro da tirania da deusa e da proximidade entre as duas narrativas está no episódio da separação dos grãos:

\footnotetext{
95 Idem, p. 234.

${ }^{96}$ Idem, pp. 251-273.

97 Idem, p. 256.

${ }^{98}$ APULEIO, L. O asno de ouro. São Paulo, Ediouro, s/d.
} 
Depois disse, dirigindo-se a Psiquê: "Disforme como és, vejo que para ganhar as boas graças de teus amantes contas com teu devotamento ao serviço. Pois bem, eu também quero experimentar se és mesmo diligente. Separa o monte confuso de sementes que aqui estão. Faze a triagem dos grãos e arranja-os em ordem. É preciso que tudo esteja arrumado e expedido até à tarde, e então submeterás o trabalho à minha aprovação"99. ("Eros e Psiquê")

Como, porém, Cinderela insistisse, a madrasta acabou dizendo:

- Esvaziei um prato de lentilhas nas cinzas. Se catares todas as lentilhas dentro de duas horas, poderás ir conosco ${ }^{100}$. ("Cinderela")

No entanto, embora seja possível perceber essa semelhança entre Vênus e a madrasta de Cinderela, o comportamento da deusa no mito grego assemelha-se mais ao de uma outra madrasta: a de Branca de Neve. Mais do que pelo ciúme materno com relação ao filho Eros, Vênus persegue Psiquê porque tem inveja de sua formosura e medo de que a moça possa roubar-lhe o título de "deusa da beleza". Esse fato remete-nos à passagem do conto de Grimm em que a antagonista pergunta ao espelho mágico: "Espelho, espelho meu, há no mundo mulher mais bela do que eu?"

Assim, se por um lado em Cinderela, a ira da madrasta recai sobre a órfã por "proteção" às filhas legítimas, em Branca de Neve a inveja é direta, ou seja, a própria rainha compete com a enteada quando esta deixa de ser uma menina para tornar-se a mais bela mulher do reino e, portanto, uma concorrente em potencial.

Fazendo uma breve comparação entre os enredos dos dois contos citados e o modo como a figura da madrasta age como "desvio" no percurso das personagens órfãs, podemos verificar dois tipos diferentes de ação. Cinderela sofre com maus tratos; a madrasta faz da órfã sua empregada (ou escrava); a menina veste-se com farrapos e vive suja de borralho (por isso

\footnotetext{
99 Idem, p. 95.

${ }^{100}$ GRIMM, J \& GRIMM, W. Op. cit., p. 22.
} 
mesmo em algumas versões o nome do conto é Gata Borralheira). Nem por isso ela sai de casa. Alia-se à aveleira ${ }^{101}$ e com sua ajuda consegue passar pelas provas impostas e ir ao baile, onde conhecerá o príncipe. A influência da madrasta em sua trajetória apenas torna sua vida mais dura, o que de certo modo Ihe dá forças para seguir adiante no seu propósito de conquistar o filho do rei.

Já em Branca de Neve o papel da madrasta é outro: quando descobre por meio do espelho mágico que a beleza da enteada se sobrepunha à sua, a vilã é tomada pela inveja e pelo ódio de tal modo que não titubeia em desejar e planejar a morte da menina, fato que somente não se concretiza por piedade do caçador incumbido da tarefa.

Ao fazer uma análise desse conto, Bruno Bettelheim lembra que a madrasta de Branca de Neve só se torna uma "madrasta típica" quando a beleza da heroína começa a se opor de fato à vaidade da vilã:

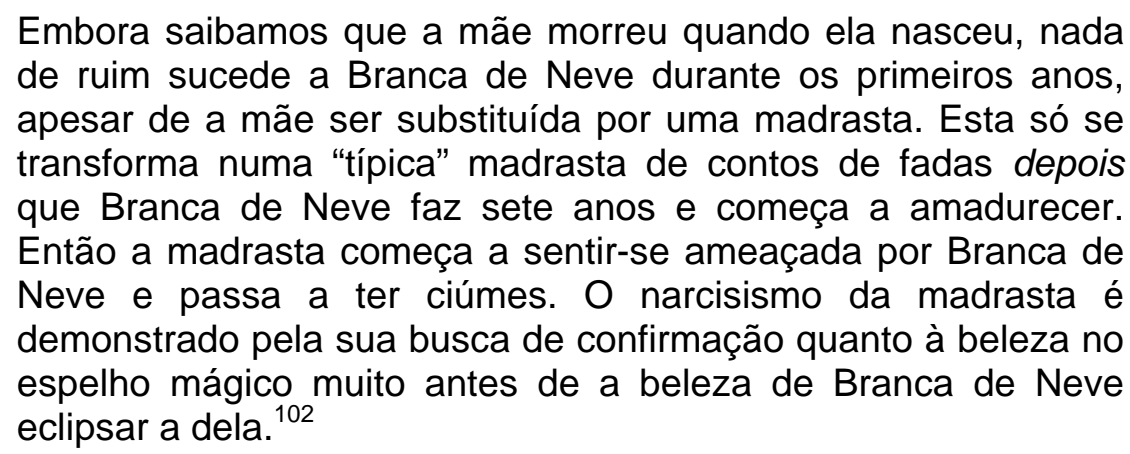

Para preservar sua própria vida, Branca de Neve não tem outra saída senão fugir, partindo para longe da comodidade do palácio onde era criada e passando por diversas provações, entre a própria ameaça de morte feita pelo caçador, o abandono na floresta e o encontro com o desconhecido,

\footnotetext{
${ }^{101}$ Há versões em que a aveleira é substituída por uma "Fada-madrinha" ou outro objeto ou ser mágico que cumpre o mesmo papel.

${ }^{102}$ BETTELHEIM, B. Op. cit., p. 242.
} 
na casa dos anões.

Bettelheim analisa esse período como um "caminho desesperadamente solitário" em que o herói luta para buscar-se a si mesmo ${ }^{103}$. Completa afirmando que, em Branca de Neve, "são os anos que passa com os anões que representam o período de dificuldades, de elaboração dos problemas, seu período de crescimento"104.

Desse modo, tomando a estrutura dos dois contos, temos dois percursos diferentes: enquanto o desvio no caminho de Cinderela se dá dentro de casa, quando a protagonista se vê obrigada a cumprir um papel menor para depois triunfar sobre a madrasta e suas filhas, o desvio causado pela madrasta de Branca de Neve a conduzirá - por caminhos tortuosos, vale dizer - ao encontro do príncipe, que por sua vez remediará todos os males causados pela vilã.

Outro conto recolhido pelos Irmãos Grimm em que a madrasta faz o papel de "desvio" no caminho de uma jovem é Rapunzel. Porém diferentemente da inveja ou do desprezo (em prol das filhas legítimas) manifestados pelas antagonistas de Branca de Neve e Cinderela, respectivamente, é por ciúme que a mãe adotiva de Rapunzel age, prendendo a donzela em uma alta torre, acessível apenas por meio de seus longos cabelos.

Neste conto, a heroína, impedida de sair de sua "prisão perpétua", apaixona-se por um príncipe e é correspondida. Ao descobrir as visitas inoportunas do rapaz à torre, a madrasta/ bruxa de Rapunzel traça mais um desvio em seu caminho, isolando-a, mesmo grávida, no deserto, onde somente

\footnotetext{
103 Idem, p. 241.

${ }^{104}$ Idem, ibidem.
} 
alguns anos depois ela iria reencontrar-se com o príncipe e retomar o caminho da felicidade. Esse período de isolamento no deserto e a "perda temporária do grande amor" por que passou Rapunzel remete-nos novamente ao mito sobre Eros e Psiquê, em que a protagonista teve de enfrentar momentos semelhantes de busca e de solidão para finalmente poder reviver sua história de amor com o deus.

Marina Warner acredita que esse tipo de enredo, que traz madrastas/ sogras como vilãs causadoras de suplícios às enteadas/ noras, pode denotar uma experiência comum na sociedade medieval e no início da era moderna, "quando a nora trabalhava sob a direção da mãe de seu marido, a quem fora entregue muitas vezes por um acordo familiar na tenra juventude ou até mesmo na infância" ${ }^{105}$. A autora afirma, ainda, que, na época em que começaram a surgir os contos de fadas, a sogra "tinha bons motivos para temer a esposa do filho"106, uma vez que, vivendo geralmente bem mais do que o marido, não era raro a viúva ter de ser sustentada pelos filhos ou genros, tornando-se um "peso" indesejável para a família ${ }^{107}$. Acrescenta, por fim:

A mãe que persegue heroínas como Cinderela ou Branca de Neve pode esconder sob suas feições cruéis outro tipo comum de mãe adotiva: não a madrasta, mas a sogra, e o período por que passa a heroína do conto de fadas pode representar não o intervalo liminar entre a infância e a maturidade, mas sim outro campo experimental ou limiar, mais socialmente constituído: o início do casamento ${ }^{108}$.

A figura da madrasta, porém, não contracena apenas com jovens donzelas ou princesas. No conto de Hans Christian Andersen, O Patinho

\footnotetext{
${ }^{105}$ WARNER, M. Op. cit., p. 256.

106 Idem, ibidem.

107 Idem, pp. 260-2.

108 Idem, p. 85.
} 
Feio ${ }^{109}$, por exemplo, o protagonista é "adotado" por uma mãe pata que, embora não aja de forma premeditada ou consciente, acaba por afastar o filho "diferente", rejeitando-o. Sentindo-se excluído pela família, o Patinho deixa para trás o terreiro em que nasceu e parte para o mundo em busca da aceitação e do seu espaço; no fundo, busca sua identidade perdida.

Clarissa Pinkola Estés, em Mulheres que correm com os lobos, lembra que "Andersen escreveu dezenas de histórias sobre o arquétipo do órfão", sendo "um importante defensor da criança perdida e negligenciada"110. Sugere ainda que a personagem da mãe pata, embora nem ela mesma soubesse, era na realidade "madrasta" do Patinho, uma vez que criava o filho de outra fêmea. Talvez por isso, inconscientemente, o tratasse de modo diferente, criticando-o e nutrindo por ele um desprezo equivalente ao de outras madrastas de contos de fadas.

Analisando o comportamento da mãe pata desde o início do conto, a autora postula:

A mãe pata a princípio tenta defender esse patinho, que ela acredita pertencer à sua prole. Afinal, porém, ela fica profundamente dividida em termos emocionais e deixa de se importar com o filhote estranho. Seus irmãos e outros membros da comunidade atacam-no, bicam-no e o atormentam. Sua intenção é a de fazer com que ele fuja. E o patinho feio sente um aperto no coração, por ser rejeitado por sua própria gente. ${ }^{111}$

Mais à frente, complementa:

Afinal, a mãe pata não agüenta mais a perseguição ao filhote que ajudou a pôr no mundo. O que é mais esclarecedor ainda é o fato de ela não conseguir mais tolerar o tormento a ela imposto pela

\footnotetext{
${ }^{109}$ ANDERSEN, H. C. "O patinho feio" IN: Estórias Maravilhosas. Adapt. Arnaldo de Oliveira Barreto. São Paulo, Melhoramentos, 1965, pp. 7-32.

${ }^{110}$ ESTÉS, C. P. Mulheres que correm com os lobos. 12. ed. Trad. Waldéa Barcellos. Rio de Janeiro, Rocco, 1999, p. 210.

${ }^{111}$ Idem, p. 218.
} 
comunidade quando tenta proteger seu filho "diferente". E assim ela desiste. Ela exclama para o patinho que preferia que ele desaparecesse. E o filhote torturado foge. ${ }^{112}$

Desse modo a mãe pata torna-se "madrasta pata", agindo como importante desvio no caminho do protagonista, sendo suas as palavras que antecedem a partida do filhote rejeitado:

Uma vez, estando mais nervosa, a mãe empurrou-o com o bico dizendo-Ihe:

- Eu bem desejava que fosses para muito longe daqui! $!^{113}$

Discutindo o tema da partida, Clarissa Estés lembra que, na literatura, "a questão do exílio é antiqüíssima", citando exemplos tanto na mitologia como nos contos de fadas. A autora explica que, em alguns casos, o exílio é decorrente de um "erro ingênuo", como no caso de "A bela adormecida", quando a última fada deixa de ser convidada para o batizado da princesa por "esquecimento" ou distração. Em outros casos, o exílio é conseqüência de "pura malvadeza, como quando a madrasta envia a enteada pelo bosque escuros adentro em Vasilisa, a sabida"114 (conto russo), o mesmo acontecendo em Branca de Neve.

Diferentemente do caso de Branca de Neve, no entanto, a partida rumo ao desconhecido por livre e espontânea vontade em decorrência de maus tratos ou do abandono por parte da madrasta também está presente em outras narrativas. No conto $O$ irmão e a irmã ${ }^{115}$, também recolhido pelos Irmãos Grimm, por exemplo, a madrasta é acusada como a responsável pela partida dos protagonistas:

\footnotetext{
112 Idem, p. 223.

${ }^{113}$ ANDERSEN, H. C. Op. cit., p. 17.

${ }_{114}^{11}$ ESTÉS, C. P. Op. cit., pp. 216-17.

115 GRIMM, J. \& GRIMM, W. Op. cit., pp. 29-36.
} 
O irmãozinho segurou a irmã pela mão e disse:

- Desde que nossa mãe morreu, nunca mais fomos felizes. Nossa madrasta nos espanca todos os dias e, quando chegamos perto dela, nos expulsa a pontapés. A nossa comida é casca de pão que sobra e é jogada fora. O cachorro come melhor do que nós, pois freqüentemente lhe dão um pedaço de carne. O melhor é sairmos desta casa, irmos para bem longe.

$\mathrm{E}$ as duas crianças caminharam durante todo 0 dia, atravessando prados, campos e lugares pedregosos ${ }^{116}$.

Bruno Bettelheim acredita que o abandono do lar é um artifício necessário para que o órfão cresça e encontre seu caminho. Analisando o conto em questão, Bettelheim afirma que "a estória sugere dois grandes acontecimentos da vida: deixar a casa paterna e fundar a própria família"117. Conclui lembrando que "estes são os dois períodos da vida onde somos mais vulneráveis à desintegração, porque temos que abandonar um antigo caminho de vida e adquirir um novo"118. Em suas palavras,

Aqui, como em muitos contos de fadas, ser expulso do lar representa ter que se tornar independente. A auto-realização requer 0 abandono da órbita do lar, uma experiência excruciantemente dolorosa, carregada de muitos perigos psicológicos (...) Os riscos psicológicos do processo, como ocorre sempre nos contos de fadas, são representados pelos perigos que o herói encontra nas suas andanças ${ }^{119}$.

Um outro enredo ainda mais conhecido sobre dois irmãos "soltos" no mundo, "atravessando prados, campos e lugares pedregosos", é João e Maria (Hansel und Gretel), dos irmãos Grimm. Nesse caso a partida não se dá por vontade dos irmãos, mas por abandono e negligência dos pais.

Marina Warner acredita que os Grimm tentaram amenizar as características de certas personagens e distorceram os enredos de vários contos, impregnando-os com seu "fervor católico, carregando nas tintas morais

\footnotetext{
116 Idem, p. 29.

117 BETTELHEIM, B. Op. cit., p. 101.

118 Idem, ibidem.

119 Idem, p. 100.
} 
do enredo, distribuindo castigos aos maus e recompensas aos justos, como o fim de amoldar-se aos valores cristãos e sociais dominantes"120.

A autora acredita que um desses contos "distorcidos" tenha sido justamente João e Maria, em cujo enredo original são os pais "verdadeiros" que, devido à fome e à pobreza, levam os filhos para o meio da floresta e abandonam-nos à própria sorte.

Na versão dos irmãos Grimm, a figura da mãe é substituída por uma madrasta, que induz o pai das crianças a abandoná-las para que não falte comida ao casal:

- Vou dizer-te o que temos de fazer, meu marido - respondeu a mulher. - Amanhã cedo levaremos seus filhos para o lugar mais espesso da floresta e acenderemos uma fogueira, daremos uma fatia de pão a cada um e voltaremos para trabalhar, lá os deixando sozinhos. Eles não conseguirão descobrir o caminho de volta e, assim, ficaremos livres deles.

- Não, mulher - disse o homem. - Não farei isso. Como poderei deixar meus filhos abandonados na floresta? As feras não tardarão a matá-los.

- És um idiota! - reagiu a mulher. - Preferes que nós todos morramos de fome?

E tanto atormentou o marido, que ele acabou concordando com a proposta.

- Mas eu vou ter saudades dos meus filhos! - desabafou.

As duas crianças, que não conseguiram dormir, porque estavam famintas, ouviram tudo que a madrasta disse a seu pai. [grifos nossos]. ${ }^{121}$

É interessante notar que a mulher refere-se sempre a "seus" filhos, isentando-se da maternidade, enquanto o homem às vezes usa o pronome "nossos", como no diálogo que antecede a proposta da "madrasta":

- O que vai ser de nós? Como vamos poder alimentar os nossos filhos quando já não temos nós mesmos coisa alguma para comer? ${ }^{122}$

\footnotetext{
${ }^{120}$ WARNER, M. Op. cit., p. 243.

${ }^{121}$ GRIMM, J. \& GRIMM, W. Op. cit., p. 278.

${ }^{122}$ Idem, ibidem.
} 
O próprio narrador, diferentemente de outros contos como Branca de Neve e Cinderela, não faz menção da madrasta logo na apresentação das personagens, proporcionando uma leitura ambígua:

No meio de uma grande floresta, vivia um pobre lenhador, sua mulher e seus dois filhos, um menino e uma menina, ele chamado João, e ela Maria ${ }^{123}$.

Donna Smith, em seu livro Madrastas: mito e realidade ${ }^{124}$, também aborda essa questão afirmando que:

as madrastas foram substituídas por outras personagens em algumas histórias, como, por exemplo, em "João e Maria". Só depois de os Irmãos Grimm publicarem a sua coleção em 1812 é que João e Maria passaram a ter uma madrasta. Nas primeiras versões em que os Grimm se apoiaram, a história falava de pais empobrecidos que abandonavam os filhos por não terem recursos para alimentá-los" ${ }^{\prime 125}$.

No capítulo dedicado às madrastas dos contos de fadas, contos populares, mitologia e literatura, Donna Smith reitera o que disseram Warner e Gonçalves, alertando que, na vida real, "a mulher que se torna madrasta tem uma consciência aguda do estereótipo com o qual será comparada em algum momento da vida, por outras pessoas ou por ela mesma"126. Afirma ainda que:

Os contos mais antigos e mais famosos apresentam madrastas, e elas são retratadas, sem exceção, como figuras cruéis. Mais ainda, sua crueldade é dirigida a crianças. O que poderia ser pior? Os contos populares têm evoluído, mas, embora outras características tenham se alterado, a madrasta cruel não mudou. Na verdade, hoje em dia as madrastas aparecem com mais freqüência que antigamente nas histórias que nos são familiares ${ }^{127}$.

\footnotetext{
${ }^{123}$ Idem, ibidem.

${ }^{124}$ SMITH, D. Madrastas: mito e realidade. Trad. Rosaura Eichenberg. Porto Alegre, L\&PM, 1995.

${ }^{125}$ Idem, p. 56.

${ }^{126}$ Idem, p. 48.

${ }^{127}$ Idem, pp. 48-49.
} 
Mais à frente, a autora tenta entender e explicar por que o tema da madrasta repete-se com tanta freqüência nos contos populares de todas as partes do mundo e expõe duas hipóteses, uma bem realista, baseada nas considerações de lona e Peter Opie, ${ }^{128}$ e outra levando em conta o lado mais psicológico, baseada no sistema de arquétipos de Jung ${ }^{129}$.

Na hipótese de lona e Peter Opie, o fato de o tema da madrasta se repetir nos contos de fadas tem uma explicação bem simples: seria um reflexo bem fiel da sociedade da época, na qual as pessoas morriam muito cedo e os viúvos casavam-se novamente com freqüência, vindo a madrasta a desempenhar papel de destaque na nova família, como acontece, por exemplo, com a segunda esposa na sociedade atual, devido à instabilidade ou pouca durabilidade dos casamentos.

Já na hipótese de Jung, o arquétipo da mãe teria uma natureza dupla: se por um lado a mãe significa aquela que provê, acolhe, protege, alimenta e ama, por outro pode trazer a conotação de "segredos, poderes ocultos e vorazes", o que seria aterrorizante e tornaria insuportável para a criança a idéia de odiar aquela a quem mais se ama. Daí a necessidade de se manter a mãe como ser perfeito, amoroso e divino em contraposição com a madrasta cruel, malvada e diabólica. Trata-se da universal dualidade bem versus mal, sendo o bem representado pela mãe idealizada, e o mal, pela madrasta malvada.

Bruno Bettelheim, ratifica essa dualidade, apontando que, "embora mamãe seja com mais freqüência a protetora toda-dadivosa, pode-se

\footnotetext{
${ }^{128}$ OPIE, I. \& OPIE, P. The classic fairy tales. Oxford, Oxford University Press, 1974 APUD SMITH, D. Op. cit., p. 55.

129 JUNG, C. G. ed. READ, H. The collected works. Londres, Routledge \& Kegan Paul, 1959, vol. 9 APUD SMITH, D. Op. cit., pp. 54-5.
} 
transformar na cruel madrasta se for malvada a ponto de negar a seu filhinho algo que ele deseja"130. Acrescenta ainda que:

Ao mesmo tempo em que a fantasia da madrasta malvada preserva a imagem da mãe boa, o conto também ajuda a criança a não ser assolada pela vivência de uma mãe malvada (...) As boas qualidades da mãe são tão exageradas no personagem salvador do conto de fadas quanto as maldades na bruxa. Mas é assim que a criancinha experimenta o mundo: ou como inteiramente prazeroso ou como um inferno sem alívio. ${ }^{131}$

Donna Smith afirma que, devido à manipulação dos contos antigos, muitas versões desapareceram, sobrando estereótipos e histórias mascaradas. Cita, por exemplo, o fato de que "figuras femininas agressivas e aquelas que tinham os atributos de inveja, cobiça ou vaidade tornarem-se bruxas ou madrastas". Acrescenta dizendo que "as madrastas foram usadas para sintetizar o que passou a ser visto como uma força má" e exemplifica lembrando que, em versões mais antigas, "Branca de Neve tinha uma tia invejosa e assassina, em vez de uma madrasta"132 e que Cinderela, embora tivesse uma madrasta, "era uma menina zangada e malcriada, um tanto suja e desejosa de vingança"133.

Para encerrar o capítulo de seu livro, Donna Smith - apesar de citar vários romances e peças atuais que diluem o estigma da maldade da madrasta, transformando-a, na ausência da mãe verdadeira, em uma mãe "quase ideal" - conclui que, "em toda a literatura, desde a história de Cinderela até a mais obscura peça teatral ou romance, a madrasta quase sempre aparece como uma personagem problemática e obscura, na melhor das

\footnotetext{
${ }^{130}$ BETTELHEIM, B. Op. cit., p. 84.

131 Idem, pp. 48-49.

132 SMITH, Donna. Op. cit., p. 49.

133 Idem, p. 51.
} 
hipóteses"134.

Desse modo, ainda que a literatura moderna traga exemplos de substitutas "boas" para a figura ausente da mãe, a simples menção da palavra "madrasta" evoca todo o estigma criado e cultivado pelas narrativas orais e sedimentado pelos contos de fadas.

Uma passagem do livro Menino de Engenho ${ }^{135}$, clássico da Literatura Brasileira de José Lins do Rego, ilustra bem esse preconceito quando Carlinhos, o protagonista-narrador órfão, explica a situação na casa onde foi morar após o assassinato de sua mãe:

A minha Tia Sinhazinha era uma velha de uns sessenta anos. Irmã de minha avó, ela morava há longo tempo com seu cunhado. (...) Era um temperamento esquisito e turbulento. (...) Era ela quem tomava conta da casa do meu avô, mas com um despotismo sem entranhas. Com ela estavam as chaves da despensa, e era ela quem mandava as negras no serviço doméstico. Em tudo isso, como um tirano. Meu avô, que não se casara em segundas núpcias, tinha, no entanto, esta madrasta dentro de casa. Logo que a vi pela primeira vez, com aquele rosto enrugado e aquela voz áspera, senti que qualquer coisa de ruim se aproximava de mim. Esta velha seria o tormento da minha meninice. Minha Tia Maria, um anjo junto daquele demônio, não tinha poderes para resistir às suas forças e aos seus caprichos ${ }^{136}$ [grifo nosso].

Assim, a ausência da mãe é contornada pela presença de duas tias de Carlinhos: tia Maria - a "boa", o "anjo" - e tia Sinhazinha - a "madrasta", o “demônio"...

Por causa desse "senso comum negativo" que gira em torno do termo "madrasta", quando a personagem órfã terá amor e afeto em sua criação em vez de agruras e entraves, geralmente a mãe substituta não é uma madrasta propriamente dita, mas uma tia, uma madrinha ou uma avó, como por

\footnotetext{
${ }^{134}$ Idem, pp.70-1.

${ }^{135}$ REGO, J. L. Menino de engenho. 15. ed., Rio de Janeiro, José Olympio, 1966.

${ }^{136}$ Idem, pp. 14-15.
} 
exemplo a bondosa Dona Benta, personagem de Monteiro Lobato ${ }^{137}$, que não somente cria a neta órfã Narizinho, como participa de grande parte de suas aventuras.

Como já citado nas Considerações Iniciais desta Dissertação, em $A$ menina do Narizinho Arrebitado, livro que precede toda a publicação da série 0 Sítio do Picapau Amarelo, Lobato explicita a orfandade da protagonista com a frase: "A velha vive feliz e bem contente da vida, graças a uma netinha órfã de pai e mãe, que lá mora desde que nasceu"138. Porém quando ele retoma a narrativa em Reinações de Narizinho, o desaparecimento dos pais da menina não é citado.

Várias obras trazem outros parentes ou padrinhos como tutores de órfãos. Este é o caso de alguns super-heróis, como por exemplo o HomemAranha, criado pelos tios.

Como esses casos não constituem "desvios", mas "atalhos" no percurso do órfão, serão considerados mais adiante.

\footnotetext{
${ }^{137}$ MONTEIRO LOBATO, J. B. A menina do Narizinho Arrebitado. São Paulo, Monteiro Lobato \& Cia., 1920.

${ }^{138}$ Idem, p. 3.
} 


\subsubsection{Irmãos ciumentos}

Embora os laços fraternos nos contos de fadas algumas vezes sejam motivo de força e união entre os órfãos, como ocorre por exemplo nos contos João e Maria ${ }^{139}$ e $O$ irmão e a irma ${ }^{140}$, não é raro o caso contrário, em que um irmão assume o papel de "inimigo" do outro, transformando-se em mais um desvio a ser contornado pelo órfão em seu caminho.

Os motivos que levam um irmão (ou vários) a voltar-se contra um outro - geralmente o mais novo, ou o mais fraco, ou o mais bem dotado... podem ser de naturezas bem diversas: desde a inveja ou, mais freqüentemente o ciúme, até o desprezo, a vergonha ou a pura maldade. Algumas vezes a causa da rivalidade fraterna pode ser a preferência dada a um dos filhos pelos pais ou por aqueles responsáveis por sua criação.

O fato de alguns pais demonstrarem predileção por um dos filhos, gerando instabilidade familiar, não é novidade, nem na literatura, nem na vida real.

Philippe Ariès, estudando o contexto histórico e social da criança e da família na Idade Média, encontrou textos que acusam e contestam essa prática de modo categórico, ainda que se tratando, neste caso específico, de um aspecto mais socioeconômico que emocional:

O abade Goussault, em seu Portrait d'un honnête homme de 1692, é mais veemente: "Há não apenas vaidade em se doar a melhor parte dos bens ao filho mais velho da família, para mantê-lo sempre no luxo e eternizar seu nome (...); há mesmo injustiça. Que fizeram os mais moços para serem tratados assim? Há pessoas que, a fim de estabelecer alguns de seus filhos num nível superior a seus próprios meios, sacrificam os outros e os encerram em mosteiros sem consultá-los a respeito

\footnotetext{
${ }^{139}$ GRIMM, J. \& GRIMM, W. Op. cit., pp. 29-36.

${ }^{140}$ Idem, pp. 278-89.
} 
e sem examinar se têm uma vocação real. Os pais não amam igualmente seus filhos e introduzem diferenças onde a natureza não quis fazê-lo". Apesar de sua convicção, Goussault admite ainda, como uma concessão ao senso comum, que os pais "possam ter de fato mais amor por alguns de seus filhos", mas "esse amor é um fogo que eles devem manter oculto sob as cinzas". ${ }^{141}$

Ariès complementa ainda esse pensamento com a citação de

Coustel, datada aproximadamente da mesma época (1687):

Não é que os pais façam mal em amar mais aqueles de seus filhos que são mais virtuosos ou têm mais boas qualidades que os outros. Mas digo que pode ser perigoso manifestar de forma muito gritante essa distinção e essa preferência" ${ }^{142}$.

Para concluir, o historiador afirma que as regalias conferidas ao filho mais velho acabaram por chocar-se, no início do século IX, com a opinião pública e com o novo código civil, que pregava a igualdade entre os irmãos e começava a se constituir em um importante alicerce para a construção de um conceito mais moderno de família.

Do mesmo modo que Donna Smith aponta duas hipóteses para tentar explicar a recorrência da figura da madrasta nos contos para crianças, sendo uma mais embasada em aspectos psicológicos e outra mais históricorealista, também com relação à rivalidade fraterna podemos inferir que existam essas duas possibilidades.

O contexto histórico pode ser o mesmo daquele descortinado por Ariès e difundido a partir do século XIII: privilegiar um dos filhos era uma maneira de não dividir os bens da família e tornar o "escolhido" mais forte para "evitar o perigoso esfacelamento de um patrimônio cuja unidade não estava

\footnotetext{
${ }^{141}$ ARIÈS, Philippe. História social da criança e da família. Trad. Dora Flaksman. 2. ed., Rio de Janeiro, LTC, 1981, p. 235.

142 COUSTEL. Reglès de l'education des enfants, 1687 APUD ARIÈS, Philippe. Op. cit., p. 235.
} 
mais protegida pelas práticas da sociedade conjunta e solidariedade, mas, ao contrário, era ameaçada por uma maior mobilidade da riqueza"143.

Por outro lado, o aspecto psicológico que poderia "justificar" a recorrência do tema da rivalidade entre irmãos nos contos infantis estaria no contraponto que um irmão faz ao outro, quando representam pólos opostos. Bruno Bettelheim explica essa dualidade, ao analisar os contos de fadas:

As figuras nos contos de fadas não são ambivalentes - não são boas e más ao mesmo empo, como somos todos na realidade. Mas dado que a polarização domina a mente da criança, também domina os contos de fadas. Uma pessoa é boa, ou má, sem meio-termo. Um irmão é tolo, o outro é esperto. Uma irmã é virtuosa e trabalhadora, as outras são vis e preguiçosas. Uma é linda, as outras são feias" ${ }^{\prime 14}$.

Ou seja, é a partir da dualidade lançada por figuras opostas que se constitui a força do herói. O conflito entre irmãos seria tão presente nos contos de fadas e contos populares porque a simples presença de um irmão "mau" reitera e enobrece o caráter do "bom".

Nos contos populares, não são raros os enredos em que figuram, por exemplo, três irmãos, e em cujo desfecho apenas um deles, invariavelmente o último, consegue o objetivo almejado. Seguem essa fórmula os enredos de "Os três órfãos"145 e "As três casinhas"146, por exemplo, recolhidos por Italo Calvino e analisados no primeiro capítulo desta dissertação. Em ambos os casos, a partida dos irmãos precede a jornada do herói (ou heroína) apenas para aumentar sua responsabilidade e valorizar ainda mais seu triunfo.

\footnotetext{
${ }^{143}$ ARIÈS, P. Op. cit., p. 234.

${ }^{144}$ BETTELHEIM, B. Op. cit., p. 17.

145 CALVINO, I. Op. cit., 2000, pp. 292-94.

146 Idem, pp. 84-87
} 
Porém há outros enredos em que, assim como a madrasta, os irmãos configuram um verdadeiro desvio no caminho do órfão. É o caso, por exemplo, do conto nórdico "O Patinho Feio", em que o protagonista sofre com o desprezo dos irmãos, que se unem em rejeição à sua feiúra:

O pobre patinho não sabia o que fazer. Doía-lhe o coração de se ver tão feio e maltratado por todos os patos do cercado. Não tinha esperanças de que o tratassem melhor. Os próprios irmãos também não gostavam dele. Diziam-lhe a todo instante: "Arre! Vai ser feio para lá!... Seria bem-feito que o gato te comesse"147.

Nesse conto, a rejeição dos irmãos mais velhos para com o irmão mais novo deve-se em parte à aparência física pouco convencional do caçula, que gera certo desconforto e vergonha para toda a família; porém há um componente psicológico importante que também pode ser levantado: pelo fato de ser diferente, o Patinho Feio teria - supostamente - mais atenções da mãe e das outras aves que eles encontram pelo caminho, ofuscando o brilho natural dos irmãos, o que poderia acabar gerando o ciúme fraterno.

Discorrendo sobre esse mesmo tema em Cinderela, Ana Cristina Gonçalves lembra o fato de o privilégio de um dos filhos ser fonte freqüente de ciúme entre irmãos:

Esta questão de privilégios na dinâmica familiar é freqüentemente reclamada pelas crianças. Algumas vezes é realmente observada, quando mães e pais acabam dando maior atenção, cuidado e afeto para um dos filhos; àquele que é considerado o mais frágil, ou o mais "problemático", ou o mais "dependente" ou ainda o que corresponde aos ideais dos pais, tornando-os merecedores de atitudes "diferenciadas"148.

\footnotetext{
${ }^{147}$ ANDERSEN, H. C. Op. cit., p. 17.

${ }^{148}$ GONÇALVES, A. C. Op. cit., p. 88.
} 
No caso da personagem órfã, muitas vezes os irmãos ciumentos que lhe desviam o caminho não são irmãos consangüíneos propriamente ditos, mas meios-irmãos ou irmãos adotivos. Para Bruno Bettelheim, esse seria mais um artifício dos narradores dos contos de fadas para amenizar uma situação constrangedora: o sentimento de ódio entre irmãos verdadeiros. Para o autor, assim como a madrasta acabou ocupando o lugar da "mãe má", meios-irmãos ou irmãos adotivos teriam tomado o lugar dos "irmãos maus":

O conto de fadas substitui as relações fraternas pelas relações entre irmãos adotivos - talvez um expediente para explicar e fazer com que se aceite a animosidade que gostaríamos que não existisse entre irmãos verdadeiros ${ }^{149}$.

Adotivos ou consangüíneos, o fato é que muitos irmãos e irmãs figuram como os principais antagonistas de contos em que a personagem central é órfã. E embora exista - como vimos - uma série de contos em que a temática é a rivalidade entre irmãos, nos deteremos a partir deste ponto mais especificamente à recorrência das irmãs ciumentas e invejosas que infernizam a vida da protagonista órfã.

Entre todos os contos de fadas, talvez aquele que primeiro venha à memória quando o assunto é a rivalidade fraterna seja Cinderela. Mais do que a madrasta, que impõe à órfã trabalhos e sacrifícios descomunais, são suas filhas as responsáveis, direta ou indiretamente, pelo suplício e sofrimento da menina:

A mulher com quem se casara levou consigo para o seu novo lar duas filhas, muito bonitas, muito louras e de cútis muito clara, mas de corações negros e desapiedados. E a pobre órfã teve de enfrentar uma vida repleta de sofrimentos.

${ }^{149}$ BETTELHEIM, B. Op. cit., p. 278. 
- Essa idiotinha vai ficar na sala conosco? - disseram as duas Quem quiser comer, tem que merecer. O lugar dessa idiota é na cozinha.

$\mathrm{E}$ as duas malvadas trocaram o belo vestido da órfã por uma roupa velha e rasgada e obrigaram-na a calçar um par de tamancos.

- Vejam como a orgulhosa princesa está vestida! - exclamaram, rindo às gargalhadas. E levaram-na para a cozinha ${ }^{150}$.

Cinderela não foi, no entanto, a primeira narrativa a trazer o episódio em que duas irmãs, por ciúme ou inveja, se voltam contra uma terceira. Assim como no caso das madrastas, as irmãs ciumentas também podem ser encontradas em inumeráveis fontes. No mito sobre Eros e Psiquêt ${ }^{151}$, por exemplo, as duas irmãs mais velhas da protagonista, inconformadas com a beleza e a felicidade da caçula ao lado do deus, tramam a separação do casal incitando a jovem a trair o pacto feito com o marido, de nunca olhar para ele. O desabafo de uma das irmãs de Psiquê, ao conhecer o castelo onde a mais nova morava, revela todo o seu despeito e sua indignação:

As excelentes irmãs, entrando em casa, cada vez mais devoradas pelo fel ardente da inveja, conversavam com barulhenta animação. Por fim, uma se exprimiu assim: "Aí estão, oh! iníqua fortuna, tua cegueira e tua injustiça! Por que aprovaste que filhas de um mesmo pai e da mesma mãe tivessem sortes tão diversas? Nós, as mais velhas, fomos entregues a estrangeiros para sermos suas escravas. Banidas do lar e mesmo da nossa pátria, levamos uma vida de exiladas. A última que veio, fruto tardio de uma fecundidade que ela esgotou, possui imensas riquezas, com um deus por esposo, e nem sabe usar, como é preciso, essa abundância"152.

Depois de atrapalharem a felicidade da caçula, corroídas de inveja, as irmãs de Psiquê tentam desfrutar de sua mesma sorte e, imprudentes, são punidas com a própria morte. Tragédia semelhante sucede com as irmãs adotivas de Cinderela, que têm os olhos arrancados por pombas no dia do

\footnotetext{
${ }^{150}$ GRIMM, J. \& GRIMM, W. Op. cit., p. 19.

151 APULEIO, L. Op. cit., pp. 71-101.

152 Idem, pp. 79-80
} 
casamento da princesa, além de já haverem sofrido com a automutilação dos pés, incentivada pela mãe, para que pudessem calçar o sapatinho perdido ${ }^{153}$.

Dos mesmos Irmãos Grimm, outro conto apresenta características similares às de Cinderela, porém neste caso o ciúme parte de irmãs consangüíneas, e não de filhas de uma madrasta. Trata-se do conto Um-Olho, Dois-Olhos e Três-Olhos ${ }^{154}$, em que a figura ausente é a do pai:

Como Dois-Olhos era igual aos outros seres humanos, era odiada pelas irmãs e pela mãe:

- Com teus dois olhos, não és melhor do que as pessoas comuns diziam-lhe - Não és igual a nós!

E maltratavam-na sem dó nem piedade, deixavam-na vestir farrapos e só Ihe davam para comer o pouco que sobrava. Em suma: não poupavam esforços para torná-la infeliz. ${ }^{155}$

Também nesse conto as irmãs são punidas no final, sendo obrigadas a pedir esmolas depois que Dois-Olhos parte com seu amado.

Inúmeras outras narrativas populares contêm esse mesmo tema, geralmente havendo duas irmãs ciumentas contra uma terceira ("a boa”), podendo esta ser a mais nova ou a mais velha, porém sempre a mais bela, a mais doce, a mais prendada, a mais destemida ou a mais desejada. Mais raramente, acontece também de haver a polaridade entre apenas duas irmãs, "a boa" e "a má", como nos contos Mãe Hilda (Irmãos Grimm) e O papagaio real (conto popular):

Era uma vez uma viúva que tinha duas filhas, uma das quais era bonita e diligente, e a outra feia e preguiçosa ("Mãe Hilda") ${ }^{156}$

Duas moças moravam juntas e eram irmãs, uma muito boa e a outra maldizente e preguiçosa. ("O papagaio real") ${ }^{157}$

\footnotetext{
${ }^{153}$ GRIMM, J. \& GRIMM, W. Op. cit., pp.25-28.

${ }^{154}$ Idem, pp. 254-64.

${ }^{155}$ Idem, p. 254.

${ }^{156}$ Idem, pp. 268-72.

${ }^{157}$ CASCUDO, L. C. Op. cit., pp. 80-83.
} 
Também nos dois contos portugueses recolhidos por Teófilo Braga analisados no primeiro capítulo desta dissertação há a polaridade entre duas irmãs: em "A Madrasta"158, há a recorrência da moça bonita e boa (enteada) $x$ a moça feia e má (a filha da madrasta). Já no conto "O sapatinho de cetim"159, a órfã tem uma meia-irmã muito menos prendada do que ela, por isso é alvo de inveja e de perseguição da madrasta.

Ana Cristina Gonçalves não vê diferença entre a rivalidade que atinge irmãs verdadeiras - como no caso de Um-Olho, Dois-Olhos, Três-Olhos - e aquela entre meias-irmãs ou irmãs por circunstância - como em Cinderela:

\begin{abstract}
A entrada das meias-irmãs na vida de Cinderela não provoca nada a mais do que seria a entrada de irmãs de sangue. E esta rivalidade fraterna é um dos conflitos centrais desta história. No conto, a madrasta privilegia suas filhas e reduz Cinderela a uma existência de "empregada" dentro da casa ${ }^{160}$.
\end{abstract}

Nas palavras da autora, a rivalidade entre irmãos não é desencadeada pela ausência de consangüinidade, mas pelo fato de a mãe ou o pai (no caso, a madrasta) privilegiar um filho em detrimento de outro. No conto em questão, porém, o fato de Cinderela não ser filha legítima da madrasta é fundamental para determinar os maus tratos que recebe e - nesse caso específico - fica evidente a importância da questão dos laços sangüíneos. Além disso, as filhas da madrasta não podem sequer ser consideradas meiasirmãs de Cinderela, pois, na maioria das versões encontradas, não têm qualquer grau de parentesco com a órfã, uma vez que são filhas de pais e mães diferentes.

\footnotetext{
158 BRAGA, T. Op. cit., pp. 119-20.

159 Idem, pp. 292-94.

${ }^{160}$ GONÇALVES, A. C. C. Op. cit., p.88.
} 
O preconceito e o ciúme fraterno em relação à órfã também estão presentes no conto Os três homenzinhos do bosque ${ }^{161}$, dos Irmãos Grimm, em que madrasta e filha se unem contra a filha do primeiro casamento do marido:

A mulher se tornou a maior inimiga da enteada, tratando-a cada vez pior. Odiava-a e invejava-a, pois a enteada era bonita e simpática, e a filha, feia e antipática ${ }^{162}$.

Também nesse caso a rivalidade se dá por ausência de consangüinidade, bem explicitada no início do enredo:

Era uma vez um homem viúvo, e uma mulher viúva, e o homem tinha uma filha e a mulher também tinha uma filha. As duas moças eram amigas, e um dia saíram passeando juntas e depois foram para a casa da viúva. E então a viúva disse à filha do viúvo: "Fala com teu pai que eu gostaria de me casar com ele (...)"163.

É interessante notar o fato de que "as duas moças eram amigas", e a rivalidade passa a existir apenas depois do casamento dos viúvos, que tornam as duas moças "irmãs adotivas".

Como em Cinderela, neste conto o desvio causado pela irmã (e pela madrasta) não obriga a protagonista a sair de casa, pelo contrário. Enviada ao bosque para procurar morangos embaixo da neve, a menina faz favores aos "Homenzinhos do bosque" e é recompensada pela exacerbação de suas virtudes e um casamento feliz. Já a "irmã", querendo alcançar os mesmos benefícios, tenta a sorte sem a mesma simpatia e desprendimento da primeira, sendo punida com a acentuação de seus defeitos.

Há ainda os contos em que a presença dos irmãos no enredo não constitui qualquer desvio ou atalho, mas acaba revelando fracasso ou

\footnotetext{
${ }^{161}$ GRIMM, J. \& GRIMM, W. Op. cit., pp. 505-10.

162 Idem, p. 508.

${ }^{163}$ Idem, p. 505.
} 
desvalorização dos primeiros em função do herói; isto é, para que o herói triunfe e seja louvado é preciso que outros tenham fracassado antes, e, nesses casos, os "outros" muitas vezes são os próprios irmãos. É o que ocorre, por exemplo, nos contos As três casinhas ${ }^{164}$ e Os três órfãos ${ }^{165}$, analisados no primeiro capítulo desta dissertação, ou ainda, por extensão, no conto $O$ Gato de botas $^{166}$, em que os irmãos recebem teoricamente uma herança melhor, mas quem realmente triunfa é o mais novo.

Porém quando o órfão é filho único e não possui laços fraternos de consangüinidade, nem mesmo por adoção, falsos amigos e oportunistas podem desempenhar o mesmo papel, como mais um desvio a ser contornado em sua longa e solitária trajetória.

${ }^{164}$ CALVINO, I. Op. cit., 2000, pp. 84-87.

165 Idem, pp. 292-94.

${ }^{166}$ GRIMM, J. \& GRIMM, W. Op. cit., pp.462-67. 


\subsubsection{Falsos amigos e oportunistas}

Eileen Simpson, em seu livro Orphans - real and imaginary, falando de sua própria experiência como órfã desde os seis anos de idade e analisando casos reais e literários de orfandade, afirma que "para ser razoavelmente afortunado, um órfão deve ter um irmão ou irmã próximo em idade, uma herança modesta (uma herança grande causa problemas), e parentes gentis e hospitaleiros"167.

Não contar com essa "sorte" inicial pode significar ao órfão, entre outras dificuldades, tornar-se uma presa fácil para falsos amigos e oportunistas que atravessam seu caminho, tentando ludibriá-lo e afastá-lo de seus reais objetivos.

Assim como os outros "desvios" já tratados anteriormente, o tema do ardiloso e do espertalhão que encontra no andante solitário sua vítima mais atraente também tem origens no conto popular.

Ricardo Azevedo, ao (re)criar quatro contos a partir de um substrato popular em seu livro Histórias de bobos, bocós, burraldos e paspalhões, expõe ao leitor a faceta do ardiloso em contraste com o herói parvo. No posfácio, esclarece que:

Muitos contos populares apresentam heróis valentes e invencíveis que, desafiando forças mágicas e superiores, invadem castelos inexpugnáveis, enfrentam dragões, bruxas e gigantes e acabam encontrando o tesouro, casando com a princesa e subindo ao trono.

Alguns poucos contos, porém, trazem heróis tolos, bobos, burraldos, bocoiós distraídos, que se confundem, são ingênuos, fracassam,

${ }^{167}$ SIMPSON, Eillen. Orphans: real and imaginary. Nova York, Signet Books, 1990, p. 151. ["To be reasonably lucky, an orphan should have a brother or sister close in age, a modest inheritance (large ones cause trouble), and hospitable relatives"]. 
fazem mil coisas erradas, mas, no fim, meio sem querer, sempre ou quase acabam se dando bem ${ }^{168}$.

"Façanhas do Zé Burraldo", o primeiro conto dessa coletânea, traz o perfil de um órfão tolo, como o próprio nome sugere, que, após a morte do pai, sai pelo mundo para tentar melhor sorte levando consigo a herança que lhe foi destinada: um burro e um pouco de dinheiro. Presa fácil para os oportunistas, Zé Burraldo é logo notado por dois malandros que facilmente the tomam primeiramente o burro, depois o dinheiro:

Continuou sua viagem, todo molhado, puxando o burro pela corda. Dois malandros descansavam debaixo de uma árvore. Viram o moço passar e resolveram dar um golpe. Chegando por trás, um deles conseguiu soltar o burro, sem que Zé Burraldo percebesse. Depois, rápido, deixou o bicho com o colega, amarrou a corda no pescoço e seguiu, amarrado, como se fosse o próprio burro. Ao olhar para trás, Zé Burraldo levou um susto (...) Mesmo confuso, Zé Burraldo ajudou o sujeito a retirar a corda do pescoço. (...) Triste por ter perdido o burro, mas satisfeito por ter libertado o rapaz, Zé Burraldo continuou a viagem puxando a corda vazia. Perto da cidade, encontrou, por acaso, os bandidos de novo. Os dois levavam o burro para vender na cidade (...) Zé Burraldo ficou feliz com o reencontro (...) Achando que estava fazendo um ótimo negócio, Zé Burraldo enfiou a mão no bolso e deu todo o dinheiro que tinha em troca do animal ${ }^{169}$.

Em alguns enredos, os vigaristas "pagam" no final por terem enganado o herói. Em outros, como nesta criação de Ricardo Azevedo, acabam saindo ilesos.

Outro conto em que a esperteza do oportunista facilmente se sobrepõe à ingenuidade do herói solitário - embora neste caso não se trate de uma personagem órfã - é Chapeuzinho Vermelho, cujas versões mais conhecidas são as recolhidas por Charles Perrault e pelos Irmãos Grimm (que

\footnotetext{
${ }^{168}$ AZEVEDO, R. Histórias de bobos, bocós, burraldos e paspalhões. Porto Alegre, Projeto, 2001, pp. 6-7.

169 Idem, p.505.
} 
publicaram duas delas em sua primeira coletânea) ${ }^{170}$. A lembrança dessa narrativa vale apenas para ilustrar o típico e literal "desvio" no caminho do herói solitário causado por um falso amigo ou oportunista, uma vez que a protagonista "sai da estrada, (...) se afundando cada vez mais na floresta"171.

Ao refletirmos sobre o tema do oportunismo e da esperteza versus a inocência e a ingenuidade do órfão, porém, não há nada mais categórico no repertório da literatura infantil do que os exemplos encontrados na obra clássica de Carlo Collodi, As aventuras de Pinóquio ${ }^{172}$.

Embora também neste caso não se trate de um órfão propriamente dito, pelo fato de ser um boneco de madeira, Pinóquio, ao longo da trama, refere-se a si mesmo como órfão e por quase todo o enredo age de modo solitário, deixando-se enganar muitas vezes à custa de sua simplicidade e de seu despreparo para a vida.

Assim como no conto de Ricardo Azevedo, também na história de Pinóquio os "principais" vigaristas que se interpõem em seu caminho agem em dupla, e, não contentes por terem enganado sua vítima uma vez, logo tramam um plano para ludibriá-la novamente. No original de Collodi, os oportunistas são representados por animais - o Gato e a Raposa - que abordam a marionete prometendo-Ihe fortunas e pretendendo unicamente roubar-lhe todo o dinheiro, "as cinco moedas de ouro" que ela carregava:

\footnotetext{
${ }^{170}$ Segundo Bruno Bettelheim (Op. cit., p. 206), os Irmãos Grimm recolheram e publicaram duas versões do conto; uma em que a avó e Chapeuzinho são engolidas pelo lobo e salvas pelo caçador (que é a mais conhecida), e outra, em que a menina e a velha se escondem na casa e planejam a morte do lobo.

171 GRIMM, J. \& GRIMM, W. Op. cit., p.330.

172 COLLODI, C. As aventuras de Pinóquio. Trad. Marina Colasanti. São Paulo, Cia. das Letrinhas, 2002. (Primeira edição publicada em italiano em 1883).
} 
- Quer dobrar as suas moedas de ouro? [pergunta a Raposa]

- Como assim? [responde Pinóquio]

- Quer fazer desses miseráveis cinco contos virarem cem, mil, dois mil?

- Quem dera! E como?

- Muito fácil! Em vez de voltar para sua casa, deve vir conosco.

(...)

- Então vamos! Eu vou com vocês. ${ }^{173}$

Neste caso há um desvio claro e também literal no caminho do herói. Em vez de voltar para casa e usar o dinheiro para comprar um novo livro e um paletó para seu pai, Pinóquio é induzido pelos vigaristas a enterrar suas moedas, para esperar nascer uma "árvore de dinheiro". No caminho, porém, os bandidos param para comer à custa do boneco, e resolvem abandonar o plano inicial para tomar-Ihe o dinheiro à força, disfarçando-se de assassinos.

Embora o boneco tenha sido enganado uma vez, não aprende com os próprios erros e novamente deixa-se ludibriar pela conversa dos malandros, que se fingem de desvalidos para conquistar sua confiança:

- Vejam nosso caro Pinóquio - gritou a raposa, abraçando-o e beijando-o - o que faz aqui?

- É uma longa história, disse o boneco.

(...)

$-\mathrm{E}$ as suas moedas de ouro?

- Estão aqui no meu bolso, menos uma, que eu gastei no restaurante.

- E pensar que em vez de quatro poderiam ser amanhã mil e duas mil! Por que não ouve o meu conselho? Por que não vem semeá-las no Campo dos Milagres?

(...)

- Então vamos. Eu vou com vocês ${ }^{174}$.

A frase final proferida pelo boneco - "Eu vou com vocês" -, tanto no primeiro encontro como no segundo, mostram a total confiança que Pinóquio tinha nos "amigos" que, despretensiosamente, ofereciam-Ihe ajuda para ele

\footnotetext{
${ }_{174}^{173}$ COLLODI, C. Op. cit., pp. 51-53.

${ }^{174}$ Idem, pp.82-83.
} 
multiplicar seu dinheiro.

Ludibriado, enganado, traído, só depois de muito tempo Pinóquio consegue retomar seu caminho, alterado por esse grande desvio causado pelo encontro com oportunistas.

Giorgio Manganelli, em uma precisa e atual interpretação sobre a obra de Collodi ${ }^{175}$, afirma:

A vida de Pinóquio alterna fugas e voltas. Se não tivesse no bolso aquelas moedas poderia chegar em casa. Quem sabe, iria à escola. Mas, passando pelo Grande Teatro, mudou de mundo. Após meio quilômetro de caminhada, Pinóquio está perdido. Vieram ao seu encontro dois personagens que fazem parte do eterno. São o erro, a fraude, a benevolência, a indulgência, a ferocidade. São o Gato e a Raposa. A Raposa, de pé ligeiríssimo, é manca. O Gato, de vista agudíssima, é cego. Providência invertida, os dois vigaristas se auxiliam fraternalmente. Conhecem todas as virtudes, praticando o negativo delas ${ }^{176}$.

Mais à frente, o autor complementa seu ponto de vista sobre o episódio, analisando a personalidade dos vigaristas:

O Gato e a Raposa, considerados juntos, têm um destino singular: são os Criminosos Desventurados, figuras de grande prestígio poético. (...) A Raposa é eloqüente, fantasiosa, ágil em reflexos mentais, grande mentirosa inclusive de improviso: tem muito do literato. (...) O Gato é o centro do mal e, se não fosse comparsa da Raposa, seria um ótimo gângster ${ }^{177}$.

Assim como no conto de fadas, em As aventuras de Pinóquio, Gato e Raposa não são meramente gato e raposa. "Fazem parte do eterno". São o "erro" e a "fraude"; a mentira e a trapaça; o oportunismo e a malícia; a falsidade e a tapeação. São parasitas da sociedade que vivem à custa da ingenuidade e da boa-fé de indivíduos como Pinóquio.

\footnotetext{
${ }^{175}$ MANGANELLI, G. Pinóquio: um livro paralelo. Trad. Eduardo Brandão. São Paulo, Cia. das Letras, 2002.

176 Idem, p. 68.

177 Idem, pp. 100-101.
} 
Falsos e enganadores, os vigaristas têm sua "merecida punição" no final do enredo, quando, novamente a caminho de casa depois de vários outros percalços, Pinóquio reencontra os malfeitores sentados no meio-fio, pedindo esmolas. O Gato estava realmente cego e a Raposa, aleijada, havia vendido seu belo rabo para conseguir alguns trocados. Reconhecendo Pinóquio, suplicam por compaixão, ao que Pinóquio responde com ditados, frases feitas, provérbios da sabedoria popular:

- Se estão pobres é bem merecido. Lembrem-se do ditado que diz: "dinheiro roubado não dá fruto". Adeus, fingidos!

- Tenha pena de nós!...

- De nós!...

- Adeus, tratantes! Lembrem-se do ditado que diz: "a farinha do demônio vai-se toda em farelo".

- Não nos abandone!...

- ... done!... - repetiu o Gato.

- Adeus, tratantes! Lembrem-se do ditado que diz: "quem rouba a coberta de seu próximo, acaba morrendo sem camisa".

E assim dizendo, Pinóquio e Gepeto seguiram tranqüilamente o seu caminho ${ }^{178}$.

Neste terceiro encontro com os vigaristas, o boneco não está só, mas acompanhado do pai. Talvez por isso não caia mais uma vez da artimanha daqueles que, segundo Manganelli, "não passam de 'fingidos': vultos dissimulados, 'assassinos' que decaem agora para uma desolada consumação”. Em suas próprias palavras:

O adeus de Pinóquio ao Gato e à Raposa se articula em três provérbios, que têm a ver com a punição da "fraude". (...) Na boca do paupérrimo Pinóquio os três provérbios são honestos e antigos, motes de ancestral miséria. Pinóquio e Gepeto deixam "tranqüilamente" para trás os dois desgraçados e uma trilha os leva a uma cabana. Cumpre observar que todo esse itinerário é apenas de Pinóquio; Gepeto se cala, reconhece os interlocutores do filho e sabe que o filho está executando um rito do qual ele pode ser apenas testemunha. ${ }^{179}$

\footnotetext{
${ }^{178}$ COLLODI, C. Op. cit., p. 205.

${ }^{179}$ MANGANELLI, G. Op. cit., p. 184.
} 
De fato, a companhia do pai torna Pinóquio forte o bastante para enfrentar verbalmente aqueles que o haviam enganado por mais de duas vezes.

Para Manganelli, a "decadência dos dois 'fingidos' anuncia o fim do mundo alucinatório e mundano, dos enganos infantis e cósmicos"180.

Para Campbell, a "conclusão do ciclo da infância é o retorno ou reconhecimento do herói; é o momento em que este, depois do longo período de obscuridade, tem revelado seu verdadeiro caráter"181.

Inevitáveis são os desvios no caminho solitário do órfão. O que mostra a sua força é a coragem para retomar a trajetória desviada.

Para Campbell, "a aventura pode começar como um mero erro (...); igualmente, o herói pode estar simplesmente caminhando a esmo, quando algum fenômeno passageiro atrai seu olhar errante e leva o herói para longe dos caminhos comuns do homem"182. No caso de Pinóquio, seu "erro" primeiro foi desviar-se do caminho da escola para seguir o "som" dos pífaros ${ }^{183}$, como um "chamado para a aventura".

Muitos enredos trazem desvios "forçados", como madrastas, irmãos ciumentos ou oportunistas. Desvios que, contornados, levam o herói ao inevitável "final feliz". Porém certamente o final dos contos de órfãos não seria o mesmo se, no mesmo caminho em que eles se depararam com desvios, não tivessem contado também com muitos e preciosos "atalhos".

\footnotetext{
180 Idem, p. 183.

181 CAMPBELL, J. Op. cit., p. 318.

182 Idem, p. 66.

${ }^{183}$ COLLODI, C. Op. cit., p. 37.
} 


\subsection{Atalhos: a amizade, o sobrenatural e a benevolência no caminho do órfão}

O herói é auxiliado, de forma encoberta, pelo conselho, pelos amuletos e pelos agentes secretos do auxiliar sobrenatural. (Joseph Campbell) $^{184}$

Do mesmo modo que a personagem órfã freqüentemente se depara com desvios em seu percurso, não raros, em contrapartida, são os "atalhos" que se apresentam para ajudá-la a superar seus obstáculos e vencer seus desafios.

Esses atalhos podem ser caracterizados por uma madrinha, uma fada, um animal, um amuleto, um ser encantado; entes que, de uma maneira bastante despretensiosa, interpõem-se em seu caminho e costumam auxiliar o órfão na retomada de sua trajetória, principalmente após um "desvio", como é, por exemplo, o caso da fada-madrinha, em Cinderela, ou dos anões, em Branca de Neve.

Em sua caracterização a respeito do conto como "forma simples", André Jolles classifica as fadas e figuras similares como aliadas fundamentais na reparação da "injustiça" inicial do conto, citando como exemplo o papel do gato em $O$ Gato de botas, em cujo enredo a "injustiça" inicial se depositaria no fato de o filho mais novo ter recebido herança muito inferior àquela de seus irmãos:

${ }^{184}$ CAMPBELL, J. Op. cit., p. 102. 
Portanto, o Gato de Botas (...) é, antes, o veículo necessário para que a injustiça seja reparada, o animal sem valor que permite ao filho pobre do moleiro receber mais do que aquilo de que o destino 0 privara $(\ldots)^{185}$.

Assim como a personagem do gato em $O$ Gato de botas, os anões em Branca de Neve, a varinha de condão em Cinderela ou a Fada Azul em Pinóquio, seres e objetos mágicos, amigos e animais sempre aparecem de uma forma ou de outra para tornar a vida do herói órfão menos árida e solitária, encurtando ou tornando mais fácil seu caminho, agindo como verdadeiros "atalhos" na sua busca da felicidade.

Amigos e amuletos aparecem com bastante freqüência em contos populares, assim como animais mágicos que, como nas fábulas, "conversam" com os protagonistas e prometem ajuda em troca de uma boa ação ou favor. Outras figuras conhecidas são velhas feiticeiras ou bruxas, disfarçadas ou não, que ora dão amuletos, ora importantes pistas ou conselhos ao herói solitário.

Iniciaremos nosso percurso sobre esses atalhos analisando uma personagem bastante recorrente nos contos de órfãos - a "fada-madrinha" -, que, como o próprio nome diz, vêm substituir a mãe, desta vez não no papel de desvio, como no caso da madrasta, mas como uma importante vereda para tornar seu caminho solitário mais curto e aprazível.

${ }^{185}$ JOLLES, A. Op. cit., p. 203. 


\subsubsection{A figura da "fada-madrinha"}

Do mesmo modo que a simples menção da palavra "madrasta" evoca uma série de sentimentos negativos, como ódio, inveja, maldade, ciúme, desprezo e perversidade, a presença de uma madrinha na narrativa pode configurar o conforto, a proteção e o amor que falta à personagem órfã na ausência da figura materna.

Antagonicamente à figura da madrasta invejosa, perversa e malvada, as madrinhas geralmente exercem uma função de cumplicidade e amparo ao órfão.

Segundo o ponto de vista religioso, os padrinhos devem substituir os pais em caso de morte ou impossibilidade na criação de seus filhos. Em algumas culturas, são os padrinhos também os responsáveis pelo suporte financeiro dos afilhados, quando os pais não têm condições de arcar com o seu sustento.

Devido a esse fato, a madrinha é muito mais bem aceita pelos órfãos por ser uma substituta "natural" da mãe no que se refere ao cuidado para com os afilhados, geralmente não tendo qualquer relação com a vida do pai viúvo, diferentemente do caso da madrasta, que de uma forma ou de outra acaba "roubando" o lugar da mãe.

Na literatura, a figura da madrinha costuma aparecer só, não tendo qualquer vínculo com outras personagens, além do próprio enteado: não costumam ter filhos, por exemplo - ao contrário de algumas madrastas -, geralmente não têm marido ou outros afilhados; são apenas madrinhas ou fadas que se desdobram para tornar mais amena a trajetória de seus 
protegidos.

No conto popular Almofadinha de ouro ${ }^{186}$, por exemplo, a madrinha da protagonista órfã é a própria Nossa Senhora, encarnada para ajudá-la a superar seus desafios:

A mocinha começou a viver amargurada e sofrendo toda a espécie de privações e insultos. De tanto padecer, perdeu a paciência e achou que o remédio era fugir daquele purgatório. Antes de tomar essa decisão, a moça rezava todas as noites à Nossa Senhora, que era sua madrinha, pedindo que the ensinasse os caminhos do bom proceder. Nossa Senhora virou-se numa velhinha e falou com ela no caminho do rio, explicando tudo ${ }^{187}$.

Nesse conto, a transformação da santa em uma "velhinha" permite que a figura da madrinha fique mais próxima da heroína órfã, uma vez que ela desce do céu "inatingível”, tomando forma humana, para presentear a afilhada com um amuleto da sorte, no caso, a "almofadinha de ouro".

Também em algumas versões da lenda gaúcha $O$ negrinho do pastoreio $^{188}$, a madrinha do escravo é a própria Nossa Senhora:

Um escravo, pequeno ainda, muito bonitinho e preto como carvão e a quem todos chamavam somente - o Negrinho. A este não deram padrinhos nem nome; por isso o Negrinho se dizia afilhado da Virgem, Senhora Nossa, que é a madrinha de quem não a tem ${ }^{189}$.

\footnotetext{
${ }^{186}$ CASCUDO, L. C. Op. cit., pp. 67-70.

187 Idem, p. 67.

188 FAGUNDES, A. A. Mitos e Lendas do Rio Grande do Sul. 7. ed., Porto Alegre, Martins Livreiro, 2000, pp.119-121. Antonio Augusto Fagundes afirma que "esta é a mais popular das lendas gaúchas, a ponto de, inclusive por gente importante, ser considerada única genuinamente rio-grandense". Complementa suas notas sobre a narrativa lembrando que 0 texto mais antigo é o de Apolinário Porto Alegre, publicado em 1875, a partir do qual a lenda ganhou muitas versões, tendo sido exportada para Argentina e Uruguai, países em que nem houve escravidão propriamente dita. O autor explica ainda que a primeira versão em que aparece Nossa Senhora como madrinha do Negrinho é a de Simões Lopes Neto (Lendas do Sul, 1913), utilizada nesta dissertação.

189 LOPES NETO, J. S. Contos e lendas. Rio de Janeiro, Agir, 1957, p. 109.
} 
Embora nesta lenda a madrinha Nossa Senhora não surja como uma velhinha como no conto recolhido por Câmara Cascudo, sua figura aparece em alguns momentos em que o escravo dorme para confortá-lo e, no final, quando o Negrinho é açoitado e condenado à morte no formigueiro, a madrinha livra-o do sofrimento, descendo do céu para levá-lo com ela:

Gemendo, gemendo, o Negrinho deitou-se encostado ao cupim e no mesmo instante apagaram-se as luzes todas; e sonhando com a Virgem, sua madrinha, o Negrinho dormiu ${ }^{190}$.

\section{$(\ldots)$}

Qual não foi seu grande espanto, quando chegado perto, viu na boca do formigueiro o Negrinho de pé, com a pele lisa, perfeito, sacudindo de si as formigas que o cobriam ainda!... O Negrinho, de pé, e ao lado, o cavalo baio e ali junto, a tropilha dos trinta tordilhos... e fazendo-Ihe frente, de guarda ao mesquinho, o estancieiro viu a madrinha dos que não a têm, viu a Virgem, Nossa Senhora, tão serena, pousada na terra, mas mostrando que estava no céu... Quando tal viu, o senhor caiu de joelhos diante do escravo ${ }^{191}$.

A grande diferença entre a madrinha Nossa Senhora do conto "A almofadinha de ouro" e a da lenda O Negrinho do pastoreio é o fato de a primeira ter uma aparição rápida e única no início do conto para presentear a afilhada com um objeto mágico, que por sua vez se encarregará de fazer suas vontades, enquanto a segunda aparece várias vezes durante o enredo como "ela mesma" e não oferece ao afilhado qualquer adorno ou amuleto, mas o protege e o conforta com sua própria existência.

Porém foi nos contos de fadas que a figura da madrinha ganhou um importante adereço: o título de "fada". Cabe então investigarmos um pouco sobre essas personagens que, segundo Jolles, "desempenham papel tão

\footnotetext{
190 Idem, p. 115

191 Idem, p. 117
} 
importante que se lhes deve o nome que o Conto recebeu na França e na Inglaterra, por exemplo"192.

De acordo com Nelly Novaes Coelho, as fadas "fazem parte do folclore europeu ocidental (e dele emigraram para as Américas)", tornando-se conhecidas "como seres fantásticos ou imaginários, de grande beleza, que se apresentavam sob forma de mulher"193. Em sua análise, acrescenta ainda o fato de que essa figura provavelmente tem origem celta e teria sido divulgada na Idade Média, assim como as bruxas. Para ela, as fadas,

Dotadas de virtudes e poderes sobrenaturais, interferem na vida dos homens, para auxiliá-los em situações-limite, quando já nenhuma solução natural seria possível.

Podem ainda encarnar o Mal e apresentarem-se como o avesso da imagem anterior, isto é, como bruxas. Vulgarmente se diz que fada e bruxa são formas simbólicas da eterna dualidade da mulher ou da condição feminina ${ }^{194}$.

Mais à frente, a autora acrescenta:

Estudiosos das tradições celtas definem suas fadas como "mestras de magia", que simbolizam "poderes para-normais do espírito ou potencialidades da imaginação". Em certos povos, como o irlandês, a fada céltica, de início, era vista como uma mensageira do Outro Mundo, que viajava, muitas vezes, sob a forma de um pássaro, um cisne, de preferência.

$\mathrm{Na}$ maioria das tradições, as fadas aparecem ligadas ao amor, ou sendo elas próprias as amadas, ou sendo mediadoras entre os amantes. A partir da cristianização do mundo, foi esse último sentido que predominou, perdendo-se completamente aquela outra dimensão "mágica", sobrenatural ${ }^{195}$.

Essa "mediação entre os amantes" pode ser encontrada no conto Cinderela, uma vez que é a "fada-madrinha" a responsável por tornar possível o encontro da Borralheira com o príncipe encantado.

\footnotetext{
192 JOLLES, A. Op. cit., p. 203.

193 COELHO, N. N. Op. cit., 1985, p. 31.

194 Idem, pp. 31-32.

195 Idem, p. 34.
} 
No conto em questão, a figura da madrinha é crucial no enredo, sendo o contraponto necessário às maldades da madrasta e de suas filhas, sem a qual teria sido impossível à órfã realizar seu desejo de ir ao encontro do príncipe.

$\mathrm{Na}$ versão dos Irmãos Grimm $^{196}$, o papel da fada-madrinha é desempenhado por uma aveleira, cujo galho de origem foi trazido pelo pai em uma de suas viagens e plantado junto ao túmulo da mãe de Cinderela. Assim, ao se deparar com as dificuldades impostas pela madrasta e pelas irmãs ciumentas, a órfã corre ao encontro da árvore, que lhe dá belos vestidos e condições propícias para poder ir ao baile:

Como não havia pessoa alguma em casa, Cinderela foi ao túmulo de sua mãe e, debaixo da aveleira gritou: "Sacode os ramos e faze assim: que ouro e prata caiam sobre mim". E, sem demora, uma ave lançou-Ihe do alto um vestido enfeitado de ouro e prata e sapatinhos bordados de seda e prata ${ }^{197}$.

Em outra versão ainda mais antiga, trazida a público por Giambattista Basile (1575-1632), na coletânea // Pentamerone ${ }^{198}$, a Borralheira - aqui com o nome de "Zezolla" - é auxiliada por uma fada que surge de dentro da árvore, neste caso uma tamareira.

Porém na versão mais conhecida hoje em dia, imortalizada pelos estúdios da Disney para o cinema em 1950 e hoje disponível em livros, cópias VHS ou DVD para espectadores de todas as idades, a árvore ganha corpo de uma bondosa velhinha, que se reporta a Cinderela como sua "fada-madrinha". Com sua varinha de condão e algumas palavras mágicas, a madrinha - mesmo

\footnotetext{
${ }^{196}$ GRIMM, J. \& GRIMM, W. Op. cit., pp. 19-28.

${ }^{197}$ Idem, p. 23.

198 BASILE, G. The pentamerone. Londres, John Lane the Bodley Head, 1932 APUD BETTELHEIM, B. Op. cit., pp.284-92.
} 
um pouco confusa e atrapalhada - consegue transformar uma abóbora em carruagem, alguns ratos em lindos cavalos e a órfã maltrapilha na mais bela moça do baile.

Essa versão da Disney é mais próxima daquela publicada por Charles Perrault, em 1883, na qual de fato é a fada-madrinha quem ajuda Cinderela a livrar-se do borralho para ir à festa no palácio:

Finalmente chegou o grande dia. Elas partiram para a festa e Cinderela ficou à porta, acompanhando-as com os olhos até perdêas de vista. Quando não as viu mais, ela começou a chorar. Sua madrinha, ao vê-la em lágrimas, quis saber o que tinha acontecido. "Eu queria muito... eu queria muito" Ela chorarva tanto que não conseguia falar mais nada. Sua madrinha, que era uma fada, disse: "Você queria ir ao baile, não é isso?" - "Ai, ai, queria sim!", respondeu Cinderela com um soluço. "Pois bem, se você se comportar bem, eu farei você ir"199.

Segundo Cristiane Mandanêlo de Oliveira, em seu artigo "Presença da fada-madrinha nas versões do conto Cinderela"200, no qual ela analisa e compara os textos de Grimm e Perrault, "a fada-madrinha ou sua representação por elementos da natureza (árvore, pássaros) é responsável por promover o afastamento temporário das cinzas (borralho) e criar uma esperança luminosa por favorecer a ida ao baile". A autora atribui também à fada, mesmo que indiretamente, a responsabilidade pelo casamento da heroína "(equilíbrio e felicidade)" e pelo "início de um lar (amor)"201.

Tomando somente essas duas versões em questão, é necessário apontar ainda algumas diferenças básicas entre as "madrinhas" presentes nos contos de Grimm e Perrault.

\footnotetext{
199 Idem, p. 23.

200 OLIVEIRA, Cristiane Madanelo. "Presença da fada-madrinha nas versões do conto Cinderela" Disponível em <http://www.graudez.com.br/litinf/trabalhos/contosdefadas.htm>. Acessado em 02/10/2005.

${ }^{201}$ Idem, ibidem.
} 
No primeiro, inclusive por se tratar de um elemento da natureza uma árvore -, a madrinha tem uma atitude bastante passiva diante das dificuldades da afilhada; sendo assim, é a órfã que vai até ela buscar ajuda. Nessa versão, também é Cinderela quem profere as palavras mágicas necessárias para que o encanto funcione:

Sacode os ramos e faze assim

Que ouro e prata caiam sobre $\mathrm{mim}^{202}$.

Só é possível notar uma atitude ativa da madrinha quando ela aparece não mais na forma de árvore, mas na voz de pombos, que denunciam a fraude das irmãs de Cinderela, que tentavam ludibriar o príncipe:

Tiveram, contudo, de passar pelo túmulo da mãe de Cinderela, e lá dois pombos pousaram na aveleira e cantaram:

"Há sangue dentro do sapato,

Repara bem, repara bem

Um pé bem grande, um desacato!

Outra é a noiva que te convém"203.

Outra postura ativa dos pombos é o castigo que instituem para as filhas da madrasta, furando-Ihes os olhos no dia do casamento da órfã.

Já na versão de Perrault, a fada-madrinha aparece no enredo por "conta própria", quando a menina começa a chorar pelo fato de não poder ir ao baile, e, sem qualquer evocação da afilhada, oferece-lhe ajuda, tendo uma atitude sempre ativa, em contraposição àquela encontrada na recolha dos Grimm. No final do conto, ela volta a aparecer para vestir a afilhada com uma roupa ainda mais bela do que as fornecidas para os bailes.

${ }^{202}$ GRIMM, J. \& GRIMM, W. Op. cit., p. 23. 
Porém não se pode negar que, tanto em Grimm quanto em Perrault, a fada-madrinha - seja como mulher, aveleira ou pombos - é fundamental como atalho no caminho de Cinderela, sem o qual não seria possível o desfecho do enredo tal como o conhecemos, principalmente depois dos desvios causados pela madrasta e por suas filhas invejosas.

Outra "fada-madrinha" famosa por criar atalhos nos caminhos tortuosos de uma personagem órfã da Literatura Infantil é a Fada Azul, de As aventuras de Pinóquio ${ }^{204}$. No original de Collodi, é a Fada quem salva Pinóquio das agruras por que passa nas mãos de malfeitores, além de alimentá-lo e protegê-lo quando está doente, dando-lhe remédios e conselhos. A "menina de cabelos azuis", como é nomeada primeiramente pelo narrador, é vista por Pinóquio como uma "boa irmã", por apresentar-se com o corpo de uma menina:

- Como a senhora é boa, minha Fada - disse a marionete, enxugando os olhos - e como eu gosto de você!

- Eu também gosto de você - respondeu a Fada - e se você quiser ficar comigo, será meu irmãozinho e eu serei sua boa irmãzinha... ${ }^{205}$

Depois, ao aparecer para Pinóquio como uma mulher feita, a Fada deixa de ser a "irmãzinha" e passa a desempenhar para o boneco o papel da mãe que ele nunca teve:

- Está lembrado? Você me deixou menina e agora me reencontra mulher, tão mulher, que eu poderia ser sua mãe.

- Gostei muito, porque assim, em vez de irmã, vou chamá-la de mãe. Faz tanto tempo que sonho em ter uma mãe como todos os outros meninos!... 206

\footnotetext{
${ }^{204}$ No original em italiano a fada é designada pela primeira vez como "la Bambina dai capelli turchini" ("A menina dos cabelos azuis"). Pinóquio a chama de "mia Fata" ("minha fada", p. 69), "sorellina" ("irmãzinha", p. 91) "Fatina mia" ("minha Fadinha", p. 81) e depois "mia mamma" ("minha mamãe", p.120). COLLODI, C. Op. cit., pp. 68-214.

${ }^{205}$ COLLODI, C. Op. cit., p. 80.

${ }^{206}$ Idem, p. 120.
} 
Na versão da Disney para o cinema (Pinóquio, 1940), a Fada Azul sempre na forma adulta e em um papel bastante modificado, mas não menos importante - é uma estrela que desce do céu e ganha corpo de uma bela fada para atender ao pedido do velho Gepeto e dar vida à sua marionete. Assim, além de ser responsável por fazer Pinóquio falar e movimentar-se, mais tarde, a Fada irá também salvá-lo de uma de suas confusões e ajudá-lo a se transformar em um "menino de verdade".

Para Nelly Novaes Coelho, Collodi funde "o maravilhoso sobrenatural dos contos de fadas com o racionalismo realista dos contos exemplares" ao publicar As aventuras de Pinóquio, em $1883^{207}$. Cita ainda o fato de a Fada Azul ser a "madrinha-mágica com que todas as crianças sonhavam (ou sonham?)”. Para concluir, acrescenta:

O maravilhoso feérico está sempre presente em Pinóquio, mas, cedendo ao pensamento positivista e à orientação educadional vigentes na época, Collodi transforma o mágico em instrumento do racional e faz de seu livro um excelente e alegre manual de conduta para os pequenos leitores da sociedade progressista em ascensão ${ }^{208}$.

Sem entrar no mérito da questão didática ou moralista em Pinóquio, o certo é que Collodi abriu precedentes e recriou à sua moda em sua obra a fada dos contos de Grimm e Perrault.

Em uma recente criação de Steven Spielberg e Stanley Kubrick para o cinema (A.l. - Inteligência Artificial, 2001), ficção científica ambientada no ano de 2141, o produtor e diretor americano retoma a figura da "Fada Azul" de Collodi como o ideal a ser buscado pelo "robô" David, filho artificial que, abandonado pelos pais adotivos em uma floresta, e aconselhado por seu

\footnotetext{
${ }^{207}$ COELHO, N. N. Op. cit., 1985, p. 81.

208 Idem, p. 82.
} 
ursinho Teddy (uma espécie de "grilo falante"), passa boa parte do filme em busca da Fada Azul, que o transformaria em um "menino de verdade" para que ele pudesse recuperar o amor de sua mãe adotiva ${ }^{209}$.

É também a busca de um ideal na figura de uma madrinha o mote utilizado por Lygia Bojunga Nunes em $A$ casa da madrinha ${ }^{210}$, em cujo enredo a autora traça a trajetória de Alexandre, menino pobre que sai da favela onde morava no Rio de Janeiro em busca do conforto que encontraria na casa de sua madrinha "misteriosa". O protagonista toma conhecimento da tal madrinha no seguinte diálogo com o irmão Augusto:

- Sabe, Alexandre? eu nunca te contei: você tem uma madrinha.

- Eu sei. Mamãe às vezes fica dizendo que eu preciso ir lá na Dona Zefa que foi ela que me batizou, que ela pergunta por que eu não vou lá, que ela isso, que ela aquilo, mas eu acho ela tão chata.

- Não! Não to falando da Dona Zefa, não. Tô falando da outra.

- Que outra?

- A outra madrinha que você tem.

- E pode? Duas?

- Pode, ué. Ainda mais uma morando aqui e a outra bem longe ${ }^{211}$.

A partir dessa conversa com o irmão mais velho, e da descrição da casa onde a madrinha morava, Alexandre decide ir atrás desse lugar mágico. Embora também não se trate de um órfão propriamente dito, o protagonista é abandonado pelo irmão mais velho e seu melhor amigo (Augusto) e pelo pai, um alcoólatra. Assim, insatisfeito com sua condição, Alexandre segue a sina dos solitários, almejando encontrar uma vida melhor na "casa da madrinha".

Em uma de suas paradas pelo caminho, ele encontra Vera, uma menina de classe econômica melhor, com quem compartilha seus sonhos,

\footnotetext{
${ }^{209}$ Outros dados sobre este filme podem ser obtidos no Capítulo 3 desta dissertação, quando trataremos do órfão no cinema.

${ }^{210}$ NUNES, L. B. A casa da madrinha. 19. ed. Rio de Janeiro, Casa Lygia Bojunga, 2003.

${ }^{211}$ Idem, pp. 67-68.
} 
cujos pais, porém, não acreditam nem um pouco na existência daquela madrinha:

- Mas tá na cara que você não tem madrinha nenhuma! Aquilo foi história que o Augusto inventou para você dormir. (...)

- Foi teu pai e tua mãe que falaram que tá na cara que eu não tenho madrinha nenhuma?

- Foi.

- Aaaaaaah bom! (...) Já tinham me avisado que gente grande tem uma inveja danada de madrinha de gente pequena (...) O Augusto já tinha me avisado dessa história. E é só bater a inveja que eles começam a querer sumir com a madrinha da gente ${ }^{212}$.

De fato, na narrativa criada por Lygia Bojunga Nunes, a "casa da madrinha" nada mais é do que a simbologia de um sonho, atrás do qual o protagonista viaja durante todo o seu percurso. Trata-se do o contraponto entre a hostilidade e a pobreza do mundo em que ele vive e a possibilidade de existir algo melhor. Além disso, pode ser vista como a metáfora da segurança, da magia e do conforto a que todas as crianças deveriam ter direito.

Existindo de fato ou apenas na sua fantasia, a madrinha de Alexandre é a responsável pela sua saída de casa na busca desse novo lugar, e é nesse "atalho" que ele encontra a amizade e a alegria, no contato com outras pessoas e seres da sua imaginação.

Sendo assim, na ausência de uma fada ou de uma madrinha propriamente dita, outras figuras podem desempenhar esse papel, seja um amigo, um ser mágico, um animal ou amuleto da sorte, que interpelam o herói em sua trajetória com o único objetivo de facilitar sua caminhada. O último item deste capítulo abordará esses importantes atalhos no percurso solitário da personagem órfã.

${ }^{212}$ Idem, pp. 128-130. 


\title{
2.2.2 Os amigos e a ajuda sobrenatural: amuletos e objetos mágicos
}

Os amigos, seres mágicos e os amuletos são outros atalhos que ajudam a tornar mais amena e segura a trajetória da personagem órfã.

Quando se encontra sozinho - e na falta de uma madrinha -, o órfão é freqüentemente "adotado" por amigos, seres fantásticos, amuletos da sorte ou animais, que o ajudam a tomar as decisões e muitas vezes lhe ensinam a melhor forma de enfrentar os desafios que o esperam.

Um dos mais conhecidos exemplos para ilustrar essa situação é a presença dos anões em Branca de Neve. Abandonada na floresta pelo caçador encarregado de tirar-Ihe a vida, a princesa consegue escapar e se esconder na casa de sete anões, que permitem sua presença em troca de trabalho doméstico, tornando-se seus amigos e protetores.

Para Bruno Bettelheim, os anos que a heroína órfã passa em companhia dos anões servem não só para protegê-la dos perigos da floresta, mas são fundamentais para que ela cresça e se desenvolva como pessoa:

\begin{abstract}
Em alguns contos de fadas, o herói tem de procurar, viajar, e sofrer vários anos de existência solitária antes de estar preparado para encontrar, salvar e reunir-se a outra pessoa numa relação que dá significado permanente às duas vidas. Em "Branca de Neve" são os anos que passa com os anões que representam o período de dificuldades, de elaboração dos problemas, seu período de crescimento ${ }^{213}$.
\end{abstract}

Mesmo depois que a órfã cai na armadilha da madrasta e come a maçã envenenada, os fiéis anões não a abandonam e protegem-na com um caixão de vidro. É a partir dessa atitude dos amigos que Branca de Neve tem a possibilidade de encontrar o príncipe e alcançar sua felicidade.

${ }^{213}$ BETTELHEIM, B. Nas terras das fadas. São Paulo, Paz e Terra, 1997, p. 50. 
Já no conto Cinderela, além e contar com a fada-madrinha, a órfã é ajudada por aves que separam os grãos das cinzas em seu lugar. Na versão da Disney para o cinema, os ratos (que depois serão transformados em cavalos para puxar sua carruagem) também auxiliam a Borralheira nos serviços domésticos e na tentativa de fazer uma roupa para que a heroína pudesse ir ao baile.

Assim como no caso da recorrência do tema da madrasta e das irmãs ciumentas, também a ajuda "sobrenatural" tem presença no mito grego sobre Eros e Psiquê. A partir do momento que Vênus impõe provas à protagonista, Psiquê conta com uma ajuda externa para cumprir as tarefas que, sozinha, provavelmente não conseguiria desempenhar. Nesse rol apresentamse como "amigos" a formiga, o caniço, a águia e até uma torre ${ }^{214}$. No episódio da separação dos grãos, é a formiga quem ajuda Psiquê a cumprir sua tarefa a contento da deusa:

\begin{abstract}
Depois de assim ter designado o montão de grãos de várias espécies, Vênus foi a uma festa de casamento. (...) Então a formiga, o humilde animalejo dos campos, medindo as dificuldades da tarefa, teve compaixão da companheira do grande deus e maldiçoou a crueldade da sogra. Correndo ativamente de um lado para outro, convocou e reuniu todo o exército das formigas vizinhas. (...) Vaga sobre vaga, desfilou todo o polvilho de seis patas e, cada qual mais diligente, todas separaram grão por grão, repartiram, agruparam por espécies, depois se apressaram a desaparecer ${ }^{215}$.
\end{abstract}

Nas ações subseqüentes, a jovem desventurada ganha outras provas, e sempre é ajudada, seja pelo conselho do caniço, pelas garras da águia real de Júpiter ou pela sabedoria da torre. A partir do cumprimento

\footnotetext{
${ }^{214}$ APULEIO, L. Op. cit., pp. 95-99.

${ }^{215}$ Idem, p. 95.
} 
dessas provas é então perdoada e salva por Eros, sendo, por fim, aceita como esposa do deus.

No conto popular, muitas vezes o amigo pode ser um animal, um ser encantado, uma velha ou feiticeira disfarçada, que oferece amuletos ao órfão e ensina-Ihe palavras mágicas em troca de um favor ou simplesmente por amizade ou solidariedade.

É o que ocorre, por exemplo, no conto O espelho mágico, analisado no primeiro capítulo desta dissertação ${ }^{216}$, no qual os amigos do protagonista são todos animais: formiga, carneiro, peixe e pássaro, a quem o órfão ajuda:

O rapaz, órfão de pai e mãe, saiu pelo mundo para ganhar a vida. la por um caminho quando viu uma pedra tapando a boca de um formigueiro e as formigas lutando para arredá-la. O moço, que tinha bom coração, abaixou-se e tirou a pedra com cuidado para não matar as formigas. Quando acabou, uma formiguinha falou:

- Se você se encontrar em dificuldades, diga: "Valha-me o rei das formigas".

O rapaz seguiu sua estrada e adiante encontrou um carneiro com uma pata enganchada num arame, Soltou o bichinho, $\mathrm{O}$ carneiro disse:

- Quando você tiver uma dificuldade, diga: "Valha-me o rei dos carneiros" ${ }^{217}$.

A partir desses encontros, o órfão põe-se a caminho para conquistar a princesa e apela para os amigos, que em vão tentam lhe ajudar. No final, tem sua vida salva pelo último animal a quem recorre, a formiga.

Também no conto popular africano $O$ rapaz do $C$ nhho ${ }^{218}$ o órfão obtém ajuda graças às suas boas ações. Ao partir para tentar conquistar a princesa por meio de sua astúcia, o jovem Nziwaeka depara-se no caminho com três velhas, uma a cada noite de viagem, às quais presta auxílio. Como

\footnotetext{
${ }^{216}$ Todos os contos populares analisados no primeiro capítulo fazem parte do Apêndice no final desta dissertação.

${ }^{217}$ CASCUDO, L. C. Op. cit., p. 88.

${ }^{218}$ ROSÁRIO, L. Op. cit., pp. 214-217.
} 
forma de gratidão, todas Ihe dão presentes: a primeira, uma caixinha mágica; a segunda, um animal; e a terceira ensina-lhe palavras mágicas. Embora sejam de naturezas bastante distintas, todos os presentes servem como atalhos para que Nziwaeka possa retornar de sua viagem com sua missão cumprida, e finalmente casar-se com a princesa.

Apenas para citar outros contos em que a boa ação do órfão é premiada com amizade e ajuda incondicional, temos ainda Os três homenzinhos do bosque ${ }^{219}$, em que a órfã é recompensada por suas ações enquanto a filha da madrasta é castigada, o mesmo ocorrendo em $O$ sapatinho de cetim $^{220}$, em que as fadas presenteiam a órfã em troca da sua boa vontade para com a cadela e na arrumação da casa, castigando sua meia-irmã, que agiu de forma oposta.

Já no conto Almofadinha de ouro ${ }^{221}$, a jovem protagonista recebe de sua madrinha um objeto mágico: a "almofadinha" que dá nome ao conto. Desse modo, quando estivesse em apuros ou precisasse de alguma coisa, bastava recorrer a ele:

Ficando sozinha, a moça tomou banho, penteou-se e pediu à almofadinha de ouro que lhe desse um vestido cor do campo com suas flores e uma carruagem com criados. Apareceu, incontinente, o pedido, e a moça vestiu-se e compareceu à festa, causando um assombro pela sua formosura e lindeza do traje ${ }^{222}$.

O amuleto faz, nesse conto, o papel da própria madrinha em outros, fornecendo à órfã os vestidos para que ela fosse ao baile no palácio, como ocorre em Cinderela.

\footnotetext{
${ }^{219}$ GRIMM, J. \& GRIMM, W. Op. cit., pp. 505-10.

${ }^{220}$ BRAGA, T. Op. cit., pp. 292-94.

${ }^{221}$ CASCUDO, L.C. Op. cit., pp. 67-70.

222 Idem, p. 68.
} 
Em A gata Borralheira, outro conto popular analisado no primeiro capítulo, desta vez pertencente ao repertório russo, a menina órfã tem como aliada uma vaquinha, que, mesmo depois de morta, ajuda-a a passar pelas agruras impostas pela família que a criou:

Um dia, a menina foi para o campo com a vaquinha malhada e contou-Ihe todas as misérias da vida a que estava sujeita, dizendoIhe:

- Ah, vaquinha, ah, mamãe! Batem-me, ralam-me, não me dão um bocadinho de pão, e ainda por cima não me deixam chorar. Para amanhã tenho que fiar, colar e tecer cinco puds de lã.

A vaquinha respondeu-lhe:

- Linda menina! Entra-me por um dos ouvidos e sai pelo outro, e tudo estará feito ${ }^{223}$.

Nesse conto, o animal (vaca) ajuda a menina órfã a passar pelas provas impostas pela família que a adotou do mesmo modo que os pássaros e as formigas ajudam Cinderela e Psiquê, respectivamente.

Também no conto português $O$ sapatinho de cetim, a menina órfã conta com a ajuda de uma vaquinha. Assim como na versão russa, mesmo depois de sacrificada, a vaca consegue auxiliá-la, conduzindo-a, neste caso, para o encontro da "casa das fadas", onde obteria ainda mais ajuda:

A vaquinha com os pauzinhos tirava o miolo do pão para a menina comer, e quando bebia água tornava a encher-lhe a bilha com a sua baba. Deste feitio enganavam a ruindade da madrasta.

Vai um dia adoeceu a ruim mulher, e quis que se matasse a vaquinha para the fazer caldos. A menina chorou, chorou antes de matar a sua querida vaquinha, e depois foi lavar as tripas ao ribeiro; vai senão quando, escapou-lhe uma tripinha da mão, e correu atrás dela para a apanhar. Tanto andou que foi dar a uma casa de fadas, que estava em grande desarranjo, e tinha lá uma cadelinha a ladrar, a ladrar ${ }^{224}$.

Ainda nesse conto, depois de seguir a "tripinha" da vaca, a menina órfã arruma a casa de fadas e, como prêmio, é agraciada com mais beleza e

\footnotetext{
${ }^{223}$ MOUTINHO, J. V. Op. cit., p. 95.
}

224 BRAGA, T. Op. cit., p. 117. 
formosura, levando para sua casa uma varinha de condão mágica que lhe daria, mais tarde, vestidos para que ela pudesse ir aos bailes do príncipe e encantá-lo, como a madrinha faz por Cinderela.

Além de objetos e palavras mágicas e de animais comuns (formiga, vaca, cachorro...), o repertório da literatura infantil está repleto de amigos quase ou tão famosos quanto o próprio órfão a quem ajudam. É o caso, por exemplo, do Grilo Falante, em As aventuras de Pinóquio ${ }^{225}$, que em vão tenta desviar o boneco dos tortuosos caminhos por onde é levado, ou da personagem-título, em $O$ Gato de $B_{0}{ }^{226}$, responsável por ajudar o órfão a obter riqueza e um bom casamento. Neste último caso, o "amigo" é tão importante na trama que passa a ser o protagonista, deixando a figura do órfão em segundo plano.

Na literatura infantil e juvenil moderna também há bons exemplos de seres mágicos e sobrenaturais que auxiliam a personagem órfã.

No romance $A$ história sem fim, clássico da literatura infantil alemã de Michael Ende $(1979)^{227}$, por exemplo, é possível verificar de forma constante e bastante numerosa a presença de amigos atuando como importantes atalhos no enredo.

Na primeira metade do livro, o protagonista - o menino órfão Atreiú tem a missão de salvar o reino Fantasia do "Nada". Para conseguir alcançar seu objetivo, o herói é ajudado por vários entes mágicos, entre eles o dragão da sorte Fuchur, a "voz" Uiulala, os gnomos Urgl e Enguivuck, entre outros,

${ }^{225}$ COLLODI, C. Op. cit., pp. 17-19.

${ }^{226}$ GRIMM, J. \& GRIMM, W. Op. cit., pp. 462-7.

${ }^{227}$ ENDE, M. A história sem fim. Trad. Maria do Carmo Cary e João Azenha Jr. 8. ed. São Paulo, Martins Fontes, 2001. O livro ganhou uma adaptação para o cinema em 1984 (The neverending story, Warner Bros, 1984). 
além do amuleto Aurin, oferecido pela Imperatriz Criança para guiá-lo e protegê-lo durante a sua jornada.

Na segunda metade do livro, o leitor-personagem e também órfão Bastian - que perdera a mãe e sofria com o desprezo do pai - é chamado para dentro do livro, onde vive outras peripécias e, do mesmo modo que Atreiú, é guiado e auxiliado por criaturas mágicas, como o leão Graograman, o gênio Illuan e o próprio Atreiú, que participa dessa segunda parte agora como amigo e não mais protagonista.

Ao final de sua aventura, com a ajuda de todo o reino de Fantasia, o órfão Bastian passa a aceitar melhor suas limitações físicas e reconquista o amor do pai, o que era na verdade seu grande desafio.

Na literatura infantil brasileira contemporânea, podemos citar ainda o breve romance do maravilhoso metafórico de Lúcia Pimentel Góes, A flauta do sótão ${ }^{228}$, em que o protagonista órfão e mudo Reinaldo - ou simplesmente Rê - conta-nos, em uma narrativa em primeira pessoa, como conseguiu sair de seu mundo de silêncio e solidão com a ajuda de dois amigos inseparáveis: o cão Aloê e a flauta Dô. No decorrer da narrativa, outros amigos aparecem, como a igualmente muda Léa, a cadela Sissy e o flautim Dom.

Assim como Bastian, em A História sem fim, o menino Reinaldo também tem no final da história um emocionante reencontro com o pai, que só se tornou possível por meio de Dô, a flauta encantada:

Nisso, alguém abriu caminho pelos curiosos que nos ouviam. Era um homem alto, de cabelos um pouco brancos.

Pára espantado, escutando, olhando muito para mim. De repente corre, me abraça, dizendo:

- Filho, filho! Tenho certeza, você é meu filho, mas como cresceu! Essa flauta foi minha.

- Pai? É você o meu pai?

${ }^{228}$ GÓES, L. P. A flauta do sótão. 2. ed., São Paulo, Paulus, 2005. 
- Pois não é o Rê e vive com a vó Tonha?

- Sou. Quanto tempo que a gente não se via, pai...

Ele quase me sufoca no abraço. Choramos nem sei bem por quê: de tanta emoção e de tanta felicidade. Aí ele explica:

- Passava por aqui quando ouvi a música Ela tocou-me o coração (...)

- Pai, a flauta é a Dô. Ela é encantada. Tão encantada que me fez a surpresa de achar você ${ }^{229}$.

Em muitas narrativas, os amigos fazem o papel de importantes pontes entre pai e filho, entre o órfão e sua futura esposa, entre a órfã e o príncipe encantado, entre o herói e o objetivo a ser alcançado.

Sem esses atalhos, provavelmente os órfãos se sentiriam ainda mais solitários e ficariam à mercê dos incontáveis desvios que se apresentam em seu caminho.

No capítulo a seguir poderemos ver mais minuciosamente como esses desvios e atalhos atuam de forma decisiva na trajetória de três personagens órfãs contemporâneas.

${ }^{229}$ Idem, pp. 37-38. 
CAPÍTULO 3

O ÓRFÃO NA ATUALIDADE EM TRÊS DIFERENTES MÍDIAS:

LITERATURA, QUADRINHOS E CINEMA 
Mais de dois séculos se passaram desde que os Irmãos Grimm fizeram sua inestimável viagem pelo interior da Alemanha recolhendo contos e memórias. Nesses duzentos anos, as carruagens que lhes serviram de transporte foram sendo gradativamente substituídas por modernas e velozes máquinas; as penas com que escreviam passaram por diversas transformações até entrarem em desuso pelos escritores, que hoje vêem seus textos fluírem diretamente de suas mentes para a tela de um computador; e boas histórias não são mais contadas por velhos sábios em sessões vespertinas ao redor do fogo, mas ganharam novos suportes e auditórios sofisticados, com som digital e tecnologia de última geração.

No entanto, seja nas páginas globalizadas da literatura moderna, na agilidade e na destreza dos quadrinhos ou na ilusão audiovisual do cinema, a temática da personagem órfã, com todos os seus desvios e atalhos, continua a fazer parte do repertório infantil e juvenil com a mesma intensidade de antes.

Neste capítulo será realizada uma análise do percurso de três personagens órfãs contemporâneas - Harry Potter ${ }^{230}$, Peter Parker ${ }^{231}$ e Luke Skywalker ${ }^{232}$-, nascidas inicialmente em três diferentes mídias: literatura, quadrinhos e cinema, respectivamente. Para isso tomaremos três fases de suas trajetórias: partida, iniciação e retorno, e, em cada uma delas, tentaremos situar seus desvios e atalhos. Antes disso, porém, faremos um breve histórico sobre a presença do órfão como personagem nesse extenso universo formado pelos três suportes aqui avaliados.

\footnotetext{
${ }^{230}$ Harry Potter (literatura). Criação de J. K. Rowling - Harry Potter and the philosopher's stone, 1997.

${ }^{231}$ Peter Parker (quadrinhos). Criação de Stan Lee - The amazing fantasy, 1962.

${ }^{232}$ Luke Skywalker (cinema). Criação de George Lucas - Star Wars, 1977.
} 


\subsection{Presença do órfão em diferentes mídias}

Um conto de fadas é o mito para a criança. Há mitos certos para cada estágio da vida. À medida que envelhece, você precisa de uma mitologia mais consistente. $(\text { Joseph Campbell })^{233}$

Três grandes fontes de cultura e entretenimento têm contribuído para perpetuar o engendramento do arquétipo do órfão em enredos bastante similares aos vividos por protagonistas de contos populares ou de contos de fadas. Literatura, Quadrinhos e Cinema foram os meios escolhidos nesta dissertação para que um paralelo entre personagens órfãs concebidas inicialmente para diferentes suportes pudesse ser delineado.

O intuito dessa diversificação de suportes é o de verificar a coexistência de temas similares no livro infantil e nas tecnologias mais recentes e supostamente mais atraentes ao público jovem.

Quando a Internet, os e-books e a mídia digital começaram a surgir e a fazer parte da vida cotidiana de milhares de leitores iniciantes, muito se discutiu a respeito da inevitável decadência do livro "de papel", cujos dias estariam "contados". Depois de cerca de uma década de quando foram divulgadas essas premissas, o que se viu foi um saudável intercâmbio entre diferentes suportes e a coexistência "pacífica" entre os tradicionais livros impressos e outros gêneros apoiados em recursos mais visuais, como os quadrinhos, as animações e os filmes.

${ }^{233}$ CAMPBELL, J. O poder do mito. 20. ed. Trad. Carlos Felipe Moisés. São Paulo, Palas Athena, 1990, p. 147. 


\title{
3.1.1 O órfão na literatura
}

Como já enfatizado nos capítulos precedentes, existe na literatura um vasto repertório de narrativas que trazem personagens órfãs como protagonistas, sendo a literatura inglesa do século XIX uma das mais efetivamente profusas na abordagem dessa temática.

Eileen Simpson, em seu livro Orphans - real and imaginary, insinua que muitas das conhecidas histórias de órfãos desse período talvez tenham sido inspiradas na vida de seus próprios autores, sem apresentar obrigatoriamente, porém, o compromisso com a verdade que uma autobiografia requer:

\begin{abstract}
Autores de autobiografias são limitados pelo esquecimento daquilo que ocorreu na infância e pela repressão de acontecimentos demasiadamente dolorosos para serem lembrados. (...) Escritores de obras de ficção, poesia e peças de teatro estão desimpedidos para criar. Guiados pela intuição e também pelas próprias experiências de certa forma relacionadas com as dos órfãos, sentem-se livres para dar asas à sua imaginação. $E$ quando imaginam com genialidade, são capazes de ampliar nosso conhecimento sobre a realidade ${ }^{234}$.
\end{abstract}

Simpson complementa seu argumento afirmando que a biografia de Charles Dickens (1812-1870), por exemplo, começa como um de seus livros, uma vez que, aos doze anos de idade, o autor vive na própria pele o abandono dos pais. De fato, uma das características mais marcantes de dois dos mais importantes romances de Dickens é a orfandade de seus heróis, protagonistas que dão nome às obras: Oliver Twist (1838) e David Copperfield (1850):

\footnotetext{
${ }^{234}$ SIMPSON, E. Op. cit., p. 200. ["Autobiographers are limited by amnesia for what occurred in infancy, and by repression of events from childhood too painful to recall. (...) Writers of fiction, poetry, and plays are unencumbered. Guided by intuition, guided also by experiences in their own lives that approximate the orphan's, they are free to imagine. When they imagine with genius, they extend our knowledge of reality"].
} 
Com o desenvolvimento do romance como gênero literário, órfãos tornaram-se heróis e heroínas capazes de despertar identificação nos sentimentos dos leitores, e cuja orfandade não era meramente declarada (como nas peças de Shakespeare ou contos picarescos), mas descrita de modo visceral, vinda do âmago da personagem. Assim como as ruas de Londres do século XIX fervilhavam de órfãos, o mesmo ocorria na ficção desse período, que os retratava de modo bastante evidente, sobretudo na obra de Dickens.

A biografia de Dickens começa como um de seus romances, quando, com doze anos de idade, ele mesmo se sente abandonado pelos pais ${ }^{235}$.

Segundo Simpson, "críticos sugeriram que Oliver Twist deveria ser lido não como um romance realista, mas como um conto de fadas" ${ }^{236}$. A autora acrescenta sua opinião, afirmando que seria ainda melhor se essa obra fosse lida como "uma coleção de pesadelos e sonhos de um órfão", ou, de fato, como "uma coleção de pesadelos e sonhos de todas as crianças"237.

O próprio Charles Dickens, no prefácio da terceira edição do romance, declara que Oliver Twist nasceu para contar aos leitores como uma criança, mesmo atravessando toda sorte de dificuldades, consegue manter-se íntegra e fiel a seus princípios, triunfando no final ${ }^{238}$. De fato, Oliver é maltratado, humilhado, abandonado, e nem por isso deixa de ter coragem para se reerguer. Contornando todos os desvios que aparecem em seu caminho - e não são poucos -, vencendo os obstáculos mais difíceis, desde a fome e a miséria até as tentações da vida fácil e as injustiças cometidas contra ele, o

\footnotetext{
${ }^{235}$ Idem, pp. 200-1. ["With the development of the novel as a genre, orphans became heroes and heroines whose feelings readers could identify with, whose orphanhood was not merely stated (as it is in Shakespeare's plays and in picaresque tales), but described as if from the inside. As the streets of nineteenth-century London swarmed with orphans, so, too, did the fiction of the period, supremely, of course, in the works of Dickens. Charles Dickens's biografy begins to read like a Dickens's novel when, at age twelve, he felt himself abandoned by his parents".]

${ }^{236}$ Idem, p. 203. ["Critics have suggested that Oliver's story should be read not as a realistic novel but as a fairy tale"].

237 Idem, ibidem. ["Even better, I found, was to read it as a collection of nightmares and daydreams of orphan children, or indeed of all children"].

${ }^{238}$ DICKENS, C. Oliver Twist. [Prefácio]. Nova York, Airmont Publishing, 1963. ["I wished to show in Oliver the principle of good surviving through every adverse circumstance and triumphing at last".]
} 
menino órfão é capaz de cativar a cumplicidade do leitor, que invariavelmente "torce" para sua felicidade depois de tanto sofrimento.

Quanto a David Copperfield, Simpson acredita que o romance deveria ter como subtítulo "Orphans All, por conter "uma verdadeira antologia dos vários graus do estado do órfão"239. Exemplifica e justifica esse pensamento afirmando que David é primeiramente órfão de pai, que morrera antes mesmo de seu nascimento. A mãe - que abre mão dos cuidados para com o filho em prol do segundo casamento - morre logo em seguida, deixando o menino à mercê das crueldades do padrasto e de outros adultos que atravessam seu caminho. Também personagens secundários, como Ham e Emily, entre outros amigos de David, são órfãos. Ou seja, embora esteja sozinho, o mundo de David Copperfield está povoado de outros órfãos, fato que, de certa forma, o torna mais preparado para enfrentar seus obstáculos.

Voltando a abordar o tema da fusão entre o real e o imaginário, Simpson atesta que, entre todos os romances de Charles Dickens, David Copperfield é o "mais obviamente autobiográfico de todos":

Pode-se ver como essa experiência traumática [o abandono] subsidiou a ficção de Dickens em Oliver Twist (1838) e no mais obviamente autobiográfico de todos os seus romances, David Copperfield (1850), para citar apenas dois com o tema do órfão ${ }^{240}$.

A autora esclarece que Dickens não foi o único autor a sobressair-se no cenário inglês do século XIX ao desenvolver o tema do órfão. Da mesma época de Oliver Twist e David Copperfield, outro romance - Jane Eyre (1847),

${ }^{239}$ SIMPSON, E. Op. cit., p. 204. ["The book (David Copperfield) might have had for subtitle, Orphans All, for it contains a veritable anthology of degrees of the parentless state"].

240 Idem, pp. 200-1. ["How this traumatic experience informed Dickens's fiction we can see in Oliver Twist (1838) and in the most obviously autobiographical of his novels, David Copperfield (1850), to take just two with the orphan theme".]. 
de Charlotte Brontë (1816-1855) - traz em seu cerne essa figura solitária, desta vez personificada em uma menina.

Assim como as obras de Dickens, Jane Eyre também considera muitos aspectos da orfandade do período, buscando confrontar a realidade da pobreza e o triste abandono dos sonhos infantis da protagonista.

Para compor a personagem central, a escritora teria procurado alguns elementos em sua própria história de vida. Órfã de mãe desde os cinco anos de idade, Charlotte foi criada até os nove anos por uma irmã mais velha, Maria, que veio a falecer logo depois. Assim como a autora, a protagonista Jane Eyre também é órfã ${ }^{241}$ e sofre igualmente uma segunda perda quando sua melhor amiga, Helen Burns, morre em seus braços. Eileen Simpson acredita que essa personagem secundária de Charlotte Brontë tenha sido inspirada em Maria, sua irmã, assim como o modelo de orfanato onde Jane Eyre passou oito anos de sua vida teria sido baseado em um internato freqüentado pela autora e por sua irmã durante dez meses.

O fato de Charlotte Brontë ter recorrido a vários subsídios de sua própria vida para compor Jane Eyre, assim como Charles Dickens, em relação a David Copperfield, não significa, porém, que todos os romances da época que trazem órfãos como protagonistas foram de certo modo autobiográficos. Um exemplo é o romance Kim (1901), do escritor britânico Joseph Rudyard Kipling $(1865-1936)^{242}$.

${ }^{241}$ A principal diferença no caso seria o fato de a autora ter sido órfã apenas de mãe, enquanto a personagem Jane Eyre era órfã de pai e mãe.

242 Escritor britânico nascido em Bombaim, Índia. Aos seis anos de idade, Rudyard Kipling foi afastado de seus pais e levado juntamente com sua irmã para um asilo em Southsea, Inglaterra, onde viveu anos de muito sofrimento. Essa experiência de vida pode ser lida em seu conto Ovelha Negra (Baa, baa, Black Sheep), de 1888. 
Embora - como Dickens - seu autor tenha sido um "órfão temporário", o enredo de Kim é bem mais alegórico e distante da realidade em que vivem os protagonistas de Oliver Twist, David Copperfield e Jane Eyre, principalmente devido ao fato de o cenário escolhido para o desenrolar dos acontecimentos ser um país "exótico" e de costumes tão diferentes como a Índia. O livro narra a história do filho de um sargento irlandês que vivia na Índia, o menino Kimball O'hara, cujos pais morreram quando ele ainda era criança. Deixado aos cuidados de uma tia, Kim aprende com seus amigos nativos a língua e os costumes indianos e passa a usar da sua astúcia e esperteza para conseguir aquilo que quer, contornando os desvios que aparecem em seu caminho.

Também de autoria de Kipling e ainda mais fantasioso do que Kim, o clássico The jungle book (1894) - O livro da selva, mais conhecido no Brasil como Mogli, o menino-lobo - traz a história de um menino órfão indiano criado por lobos desde bebê, que aprende a sobreviver na floresta em meio a feras "boas" e "más".

Quase duas décadas depois, o americano Edgar Rice Burroughs (1875-1950) usaria tema semelhante para compor sua novela Tarzan of the Apes (Tarzan dos macacos), em que o bebê órfão desta vez é criado por uma família de macacos ${ }^{243}$.

\footnotetext{
${ }^{243}$ Nascido na literatura, Tarzan apareceu pela primeira vez em 1912, na novela Tarzan of the Apes. Depois deste mais de vinte títulos foram publicados com aventuras do "Rei das Selvas", ou "Filho das Selvas", como ficou conhecido. Além dos livros, muitos filmes, seriados, animações e quadrinhos foram protagonizados pelo herói. O primeiro filme estreou em 1918, trazendo Elmo Lincoln no papel principal, e em 1929 aparecem os primeiros quadrinhos. Tarzan é certamente um dos heróis mais filmados de toda a história, tendo protagonizado mais de 40 filmes, vividos por diferentes atores. Recentemente, a Disney lançou a animação Tarzan (1999), que ganhou o Oscar de melhor canção. Com o sucesso do longa-metragem, foram feitas as continuações Tarzan e Jane (2003) e Tarzan 2 (2005), somente para VHS e DVD.
} 
Nessa época já haviam sido difundidos, nos Estados Unidos, especialmente nas bibliotecas para rapazes, outros livros de aventuras cujos protagonistas eram órfãos. Entre essas obras podemos destacar duas, que alcançam muito sucesso: As aventuras de Tom Sawyer (1876) e As aventuras de Huckleberry Finn (1884), ambos de Mark Twain (1835-1910).

Ao analisar essas duas obras, Eillen Simpson lança a seguinte pergunta: "Por que Mark Twain fez ambos - Tom e Huck - serem órfãos?" Ela mesma responde, acreditando que heróis órfãos são personagens perfeitas para histórias de aventuras, uma vez que não têm a quem dar satisfações de seus atos:

Um menino sem pais é um protagonista ideal para uma estória de aventura (assim como mostram os ainda mais aventureiros Tarzan e Super-Homem). O órfão é livre como não podem ser aqueles que vivem com suas famílias ${ }^{244}$.

Eileen Simpson acrescenta ainda o fato de Mark Twain - assim como outros autores citados anteriormente - também ter ficado órfão precocemente (o pai morreu quando ele tinha apenas doze anos de idade) e ter usado um pouco dessa experiência de liberdade e falta de uma disciplina mais rígida em casa para criar suas personagens, especialmente a de Tom Sawyer.

Para finalizar esta breve análise de heróis órfãos nascidos em literaturas de língua inglesa, vale a pena lembrar outros dois grandes clássicos infantis, recentemente trazidos para as telas do cinema ${ }^{245}$ : A Princesinha

${ }^{244}$ SIMPSON, E. Op. cit., p. 216. ["a boy without parents is an ideal protagonist for an adventure story (as those far more adventurous orphans Tarzan and Superman show). The orphan is free in the way those living with their families cannot be"].

${ }^{245}$ A princesinha (A little princess), adaptado para o cinema em 1995, teve várias versões anteriores, sendo a mais famosa a de 1939; O jardim secreto (The secret garden), 1993, ganhou uma continuação (De volta ao jardim secreto - Back to the secret garden) em 2004. 
$(1888)^{246}$ e O Jardim Secreto (1909), ambos da escritora Frances Hodgson Burnett $(1849-1924)^{247}$.

O primeiro narra a história de Sara Crewe, órfã de mãe, que é enviada para um colégio interno americano quando o pai é convocado para a guerra. $O$ segundo traz entre as personagens centrais a menina Mary Lennox, que após a morte dos pais é trazida da Índia para viver com o tio solitário em um casarão inglês que guarda alguns mistérios, entre eles um "jardim secreto". Em ambos os livros, as protagonistas demonstram grande apelo à fantasia, à criatividade $\mathrm{e}$ aos sonhos típicos da infância, que usam com propriedade para combater os maus tratos ou a realidade crua e sem graça do mundo em que vivem.

Assim como outros autores ingleses que se valeram da própria experiência com a orfandade para criar seus protagonistas, Frances Burnett que também ficou órfã de pai aos cinco anos de idade - vivenciou um capítulo talvez ainda mais trágico em sua vida: a morte prematura de seu filho.

É difícil de se prever o quanto uma experiência pessoal pode influenciar a ficção de um autor, mas certamente esses elementos "reais" contribuem pelo menos em parte para a construção de suas famosas personagens.

$\mathrm{Na}$ literatura portuguesa não observamos a mesma profusão de enredos que focalizem de modo categórico a temática do órfão como na literatura inglesa, apesar de grandes autores lusos terem vivido na pele a

${ }^{246}$ Inicialmente publicado com o título Sara Crew; existe certa controvérsia quanto ao ano em que teria primeiramente aparecido o título $A$ little princess, mas certamente entre $1888 \mathrm{e}$ 1909.

247 Nascida em Manchester, na Inglaterra, após a morte do pai, a escritora Frances Hogdson Burnett mudou-se para os Estados Unidos, onde passou a dedicar-se à literatura. 
orfandade ${ }^{248}$, entre eles Camilo Castelo Branco $(1825-1890)^{249}$, talvez o principal a se destacar por diferentes abordagens sobre a criança desamparada.

Um de seus enredos mais marcantes sobre o tema é o de Maria Moisés (1875) ${ }^{250}$, uma novela dividida em duas partes: na primeira parte, conta-se a história da mãe, Josefa da Lage, moça de poucos recursos que fica grávida de um fidalgo. Na tentativa de fuga com o bebê, escapa-Ihe na correnteza do rio Tâmega o cestinho que levava a criança, e, ao tentar resgatálo, a pobre acaba desfalecendo, e morre. A segunda parte do livro começa justamente onde termina a primeira, quando um pescador recolhe o cestinho com a menina recém-nascida, dando-Ihe o nome de Maria "Moisés", em alusão à personagem bíblica que teria sido encontrada em situação semelhante. A órfã cresce saudável e, na sua juventude, promete dedicar sua vida a cuidar de crianças enjeitadas. Apenas no final da novela Maria vem a conhecer seu verdadeiro pai.

Eça de Queirós (1845-1900) ${ }^{251}$ é outro autor que aborda o tema da orfandade em alguns de seus romances e contos, como por exemplo em $O$ crime do padre Amaro (1875) e em A relíquia (1877): o primeiro narra a história de Amaro, órfão desde os seis anos de idade e criado por uma marquesa, que

${ }^{248}$ Por exemplo, Teófilo Braga (1843-1924): escritor, pesquisador e político português, viveu durante a infância em um ambiente hostil após a morte prematura da mãe, quando ele tinha apenas três anos de idade. Esse ambiente e o relacionamento com a madrasta tornaram-no um inconformista, como sua vida política veio comprovar mais tarde; Mário de Sá-Carneiro (1890-1916): poeta e novelista, filho de um coronel de engenharia, ficou órfão de mãe aos dois anos, sendo relegado para os cuidados de duas criadas e de uma ama.

${ }^{249}$ Filho ilegítimo, Camilo Castelo Branco teve uma vida repleta de acontecimentos trágicos, entre eles a perda da mãe, quando ele tinha dois anos incompletos, e a perda do pai, aos dez.

${ }^{250}$ Maria Moisés faz parte das Novelas do Minho, publicadas entre 1875 e 1877.

${ }^{251}$ Também filho ilegítimo como Camilo Castelo Branco, embora não seja órfão, José Maria de Eça de Queirós passa a infância afastado dos pais. Criado pelos avós, aos dez anos é enviado ao colégio. 
também vem a falecer quando o rapaz tem apenas treze anos, deixando uma indicação para que ele seja educado em um seminário; o segundo traz as aventuras de Teodorico, órfão desde criança criado por uma tia rica a quem ele tenta ludibriar. Embora nos dois casos os protagonistas sejam órfãos, a temática não é tão determinante como em Maria Moisés, uma vez que o enredo focaliza a juventude dos rapazes, e não a sua infância.

$\mathrm{Na}$ literatura brasileira, também temos alguns exemplos de contos e romances cujos protagonistas são órfãos, ou seguem a sina dos solitários e abandonados.

Considerado o primeiro representante da prosa romântica brasileira, o romance Memórias de um sargento de milícias (1854), de Manuel Antônio de Almeida (1831-1861), traz como protagonista o menino Leonardo, "filho de uma pisadela e de um beliscão", expressão que se refere ao modo como os pais se conheceram em um navio ${ }^{252}$. Nascido de uma união ilegítima e abandonado ainda criança pelos pais, Leonardo é criado pelo padrinho e torna-se um verdadeiro "anti-herói".

Nas primeiras décadas do século $X X$, outras personagens órfãs chamam a atenção no cenário da literatura brasileira. Uma delas é a personagem-título de Monteiro Lobato no conto Negrinha (1920) ${ }^{253}$, cujo enredo traz a história de uma escrava órfã maltratada e humilhada pela patroa, que resiste aos piores castigos físicos e morais, mas não sobrevive à desilusão de voltar à realidade após conhecer o lado "bom" da vida.

${ }^{252}$ ALMEIDA, M. A. Memórias de um sargento de milícias. São Paulo, Klick, 1997, pp. 14-15.

${ }^{253}$ MONTEIRO LOBATO, J. B. Negrinha. 9. ed. São Paulo, Brasiliense, 1959. (O conto "Negrinha" foi publicado pela primeira vez em 1920 em coletânea homônima, que trazia também outros contos, entre os quais: "Fitas da vida", "O drama da geada", "O bugio moqueado", "O jardineiro Timóteo" e "O colocador de pronomes"). 
Do próprio Monteiro Lobato, podemos citar os "órfãos por circunstância" Narizinho e Pedrinho, que protagonizam as aventuras do Sítio do Picapau Amarelo. Enquanto há apenas algumas referências sobre os pais de Pedrinho na obra, Narizinho é criada pela avó.

Outro órfão bastante marcante no panorama da literatura brasileira é o menino Carlos, protagonista dos romances Menino de engenho (1932) ${ }^{254}$ e Doidinho (1933) ${ }^{255}$, ambos de José Lins do Rego (1901-1957) ${ }^{256}$, que narram, respectivamente, as aventuras do menino no engenho do avô e no colégio interno, para o qual é enviado.

Quatro anos depois da publicação de Doidinho, outro romance novamente contempla o tema da criança abandonada. Desta vez os protagonistas são meninos de rua - os Capitães da Areia $(1937)^{257}$-, grupo de pequenos ladrões e assaltantes que dão título à obra de Jorge Amado (19122001).

As pegadas deixadas pelos capitães da areia "sob o trapiche abandonado" foram seguidas de perto e décadas depois surgiram alguns desdobramentos, como o livro Pivete, de Henry Correa de Araújo $(1977)^{258}$, para crianças, e o filme Pixote, a lei do mais fraco, de Hector Babenco $(1981)^{259}$, para adultos. O tema do menor abandonado é ainda hoje explorado na literatura para crianças e jovens, como o recente Balada (2000), de Heloísa

\footnotetext{
${ }^{254}$ REGO, J. L. Menino de Engenho. 10. ed., Rio de Janeiro, José Olympio,1966.

${ }^{255}$ REGO, J. L. Doidinho. 19. ed., Rio de Janeiro, José Olympio, 1979.

${ }^{256}$ Nascido em um engenho de uma cidadezinha da Paraíba, e criado por uma tia devido à morte precoce da mãe, José Lins do Rego passou três anos de sua infância em um internato de sistema bastante rígido. Sendo assim não seriam meras coincidências as correlações entre a sua vida e a de seu protagonista, que também é criado por uma tia no engenho do avô após o assassinato da mãe, e enviado para o colégio interno, onde vive amargas experiências.

${ }^{257}$ AMADO, J. Capitães da Areia, 45. ed., Rio de Janeiro, Record, 1978.

${ }^{258}$ ARAÚJO, H. C. Pivete. Belo Horizonte, Comunicação, 1977.
} 
Prieto $^{260}$, e Esmeralda, por que não dancei $(2000)^{261}$, assinado pelo sociólogo e escritor Gilberto Dimenstein e por Esmeralda Ortiz, ex-menina de rua.

Assim como alguns exemplos encontrados na literatura inglesa do século XIX - como os já citados Oliver Twist, Jane Eyre, entre outros -, essas obras mais realistas procuram estender ao universo literário alguns aspectos da orfandade do mundo atual, buscando confrontar a desiludida realidade da pobreza e do abandono dos sonhos infantis inerentes a qualquer criança.

Um outro exemplo desse tipo de literatura é o romance africano $A s$ aventuras de Ngunga $(1973)^{262}$, de Pepetela $\left({ }^{*} 1941\right)^{263}$, que narra as peripécias de um jovem órfão aprendiz de guerrilheiro na conturbada Angola em meio à guerrilha.

$\mathrm{Na}$ verdade tanto obras de cunho mais social e humanitário como aquelas de caráter aventuresco e fantástico têm-se valido da personagem órfã como uma infalível "isca" para atrair a condescendência e a cumplicidade do leitor.

Embora freqüentemente destemidas, essas personagens são frágeis, solitárias, requerem atenção e ajuda, evocam complacência, altruísmo, solidariedade. Talvez por isso estejam há tanto tempo povoando as prateleiras das livrarias e bibliotecas e sejam tão recorrentes na imaginação de leitores e escritores em todo o mundo.

${ }^{259}$ Roteiro de Hector Babenco e Jorge Durán, baseado no livro de José Louzeiro (Embrafilme, 1981).

260 PRIETO, H. Balada. São Paulo, Brinque-Book, 2000.

261 DIMENSTEIN, G. \& ORTIZ, E. Esmeralda, por que não dancei. São Paulo, Ática/ SENAC, 2000.

${ }^{262}$ PEPETELA. As aventuras de Ngunga. Lisboa, Edições 70, 1977.

263 Artur Carlos Maurício Pestana dos Santos, mais conhecido como Pepetela (Pestana na língua umbundu), seu nome utilizado durante a guerra, é um dos mais importantes autores de Angola dos nossos dias. 
Nos últimos anos, duas séries reavivaram o protótipo do órfão na literatura infanto-juvenil contemporânea: Harry Potter, criação da britânica J. K. Rowling, que no final do século $X X$ mudou o cenário mundial da literatura infanto-juvenil ao resgatar, em milhões de crianças, jovens e adultos, o prazer e a descoberta da leitura, e as Desventuras em série, do americano Lemony Snicket, pseudônimo de Daniel Handler, que contam de modo irônico e tragicômico a triste história de Violet, Klaus e Sunny, três irmãos órfãos.

O grande diferencial da obra britânica sobre a americana talvez resida no fato de a primeira apropriar-se de um universo formado por elementos mágicos e míticos, seguindo um caminho aberto cerca de meio século atrás pelas Crônicas de Nárnia ${ }^{264}$, de C. S. Lewis $(1898-1963)^{265}$, e pela trilogia 0 Senhor dos Anéis ${ }^{266}$, de J. R. R. Tolkien (1892-1973) ${ }^{267}$.

${ }^{264}$ As Crônicas de Nárnia é o nome dado à série composta por sete livros: $O$ sobrinho do mago; O leão, a feiticeira e o guarda-roupa; O cavalo e seu menino; Príncipe Caspian; $A$ viagem do peregrino da alvorada; $A$ cadeira de prata; $A$ última batalha. Todos os livros foram publicados entre 1950 e 1956. Em 2005 foi realizada pela Disney a primeira versão para o cinema, baseada no segundo livro da série, O leão, a feiticeira e o guarda-roupa e recentemente foi publicada uma edição única com todas as crônicas em português, pela Martins Fontes. A referência da obra completa está na bibliografia desta dissertação.

${ }^{265}$ Clive Staples Lewis, escritor nascido na Irlanda, mais conhecido como C. S. Lewis, mudouse ainda pequeno para a Inglaterra, tornando-se professor de literatura em Oxford e foi amigo pessoal de Tolkien na juventude. Aos dez anos de idade ficou órfão de mãe e, embora não trate do tema do órfão propriamente dito nas Crônicas de Nárnia, seus heróis humanos - Peter, Edmond, Susan e Lucy - são temporariamente afastados dos pais devido à guerra, ficando "livres" para participar de suas aventuras maravilhosas.

${ }^{266}$ Estima-se que a saga $O$ senhor dos anéis tenha sido escrita entre 1937 e 1949. A obra é composta por três livros, que têm, além do título central - $O$ Senhor dos Anéis - os seguintes subtítulos: Volume I - A sociedade do Anel; Volume II - As duas torres (ambos publicados em 1954) e Volume III - O retorno do Rei (publicado em 1955). A referência completa sobre esses livros pode ser conferida na bibliografia.

267 John Ronald Reuel Tolkien nasceu na África do Sul e aos três anos de idade mudou-se para a Inglaterra com a mãe. O pai veio a falecer logo a seguir e oito anos mais tarde, Tolkien tornou-se também órfão de mãe, tendo sido criado por uma tia. Os núcleos familiares presentes em sua obra são sempre incompletos, formados por exemplo por tio/ sobrinho (Bilbo/ Frodo e Théoden/ Éomer), pai/ filha (Elrond/ Arwen e Théoden/ Éowyn), pai/ filhos (Denethor /Boromir e Faramir). 
Seguindo essa mesma trilha de sucesso, apoiada em um repertório mágico e nostálgico ${ }^{268}$, acaba de ser publicado o primeiro livro da série "Jack Ferrell", do escritor Jean Angelles. Jack Ferrell e a ordem do templo ${ }^{269}$ inicia a saga de mais um órfão, o menino Jack, que juntamente com o avô tentará desvendar alguns mistérios que cercam o assassinato de seu pai.

Porém para representar a literatura na análise comparativa que faremos a seguir, elegemos a personagem Harry Potter, que contém os elementos necessários a um estudo pormenorizado e vertical, e equivale às personagens provenientes das outras mídias, que também serão estudadas.

${ }^{268}$ A nostalgia aqui se refere aos elementos do passado presentes nessas obras, como por exemplo o uso de pergaminhos e penas para escrever, ou as espadas, escudos e outras armas antigas, numa clara referência àquelas utilizadas pelos cavaleiros medievais.

${ }^{269}$ ANGELLES, J. Jack Farrell e a Ordem do Templo. Brasília, LGE, 2005. 


\subsubsection{Harry Potter e a literatura - o suporte original}

A cada volume, o combate com as trevas vai se misturando mais com os pesadelos, a depressão e as incômodas mudanças que a adolescência impõe ao herói. A cada passo da saga, mais se mescla o terror externo com o interno de Potter, afinal ele tem uma bagagem triste de lembranças, uma vida solitária de órfão.

(Diana e Mário Corso) $^{270}$

Harry Potter é sem dúvida um grande fenômeno mundial no que se refere à Literatura Infantil e Juvenil de todos os tempos. Estima-se que, com os seis volumes da série até agora publicados, o número de exemplares vendidos ultrapasse a casa dos trezentos milhões. Só a primeira edição do sexto livro em inglês teve uma tiragem de dez milhões e meio de unidades e, antes mesmo do seu lançamento, 750 mil cópias já haviam sido vendidas. Harry Potter bateu inúmeros recordes de venda, entre eles o número de semanas nas listas de best sellers em todo o mundo, e o número de traduções realizadas (Figura $1)^{271}$

J. K. Rowling ( $\left.{ }^{*} 1965\right)$ pensou de forma grande e ousada quando planejou a série Harry Potter em sete livros de conteúdo expressivo e volumoso. A versão em língua portuguesa do quinto e mais extenso de todos os tomos até agora publicados contém 702 páginas impressas em tipos

${ }^{270}$ CORSO, D. \& CORSO, M. Fadas no divã. São Paulo, Artmed, 2006, p. 256.

271 Devido a todos esses números e ao marketing realizado em torno de cada novo lançamento, muitos críticos rebaixaram os romances a uma literatura de consumo, colocando em dúvida seu valor literário. Somente o tempo dirá, porém, se Harry Potter continuará a figurar na galeria das grandes personagens órfãs mundiais de todos os tempos. 
pequenos - como obras para adultos - e desprovidas de ilustrações.

Somando-se todos os volumes da obra, mais de duas mil e oitocentas páginas $^{272}$ foram necessárias para criar o mundo dos bruxos que abriga as aventuras do órfão Harry Potter e sua turma.
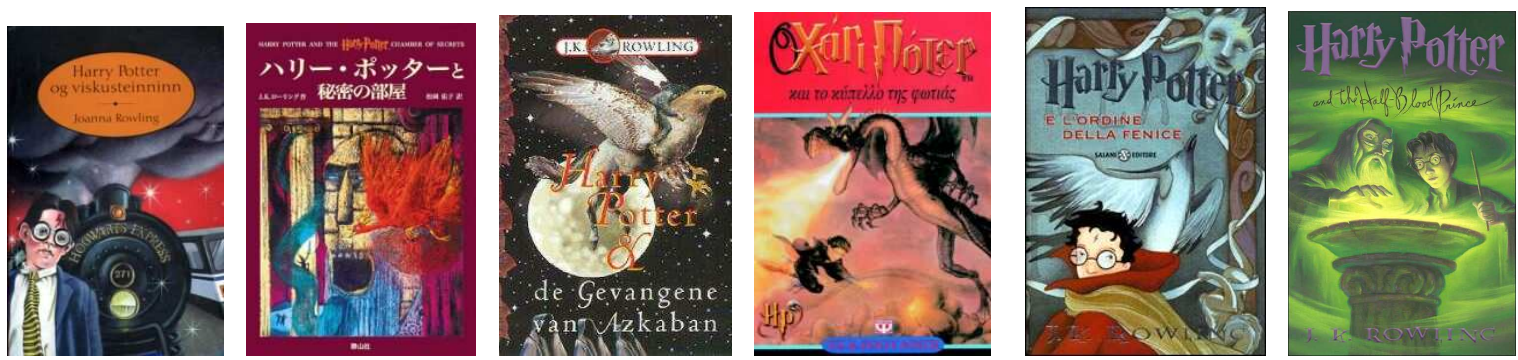

Figura 1 - Capas dos livros 1 a 6 publicadas em diferentes países: Irlanda, Japão, Holanda, Grécia, Itália e Estados Unidos, respectivamente.

Em uma entrevista registrada em 2001 no livro Conversations with J.

K. Rowling ${ }^{273}$, a autora conta como surgiu a idéia de escrever a série e afirma

que o sétimo volume será o maior de todos:

Foi numa viagem de trem de Manchester a Londres, depois de um fim de semana procurando um apartamento, que Harry Potter surgiu. (...) Eu não sabia então que seria um livro para crianças Eu sabia apenas que eu tinha esse menino, Harry ${ }^{274}$.

$(\ldots)$

Era uma questão de descobrir por que Harry estava onde estava, por que seus pais tinham morrido. Eu estava inventando isso, mas era como se fosse uma pesquisa. No final daquela viagem de trem, eu sabia que seria uma série de sete livros. Eu sei que isso parece extremamente arrogante para alguém que nunca havia publicado nada antes, mas foi como isso surgiu. Eu levei cinco anos para planejar a série, para esquematizar como seriam os sete livros ${ }^{275}$.

$(\ldots)$

${ }^{272}$ Número de páginas dos livros, em ordem: 263, 287, 348, 583, 702, 652 (publicação em inglês - Harry Potter and the Half-Blood Prince).

${ }^{273}$ FRASER, L. Conversations with J. K. Rowling. Londres, Scholastic, 2001.

274 Idem, p. 37. ["It was during the train journey back from Manchester to London, after a weekend looking for a flat, that Harry Potter made his appearance. (...) I didn't know then that it was going to be a book for children - I just knew that I had this boy, Harry"].

275 Idem, pp. 39-40. ["It was a question of discovering why Harry was where he was, why his parents were dead. I was inventing it, but it felt like research. By the end of that train journey I knew it was going to be a seven-book series. I know that's extraordinarily arrogant for somebody who had never been published, but that's how it came to me. It took me five years to plan the series out, to plot through each of the seven novels"]. 
Eu acho que o sétimo livro será o maior, como um volume da Enciclopédia Britânica, porque eu estarei me despedindo ${ }^{276}$.

\subsubsection{A obra}

Diferentemente de outras séries em que as aventuras se desenrolam em uma situação atemporal, em Harry Potter a cada novo volume passa-se um ano na vida das personagens. Assim, no início do primeiro livro o protagonista completava onze anos de idade; no segundo, doze; no terceiro, treze, e assim por diante. O sétimo livro, que pretende ser o último, contará com o herói já entrando na casa dos dezessete anos, a maioridade no mundo dos bruxos.

O enredo em cada um dos livros sempre tem início no intervalo entre um ano letivo e outro, coincidentemente no mês de aniversário de Harry $(\text { julho })^{277}$. Essa proposta faz sentido uma vez que a maioria das "peripécias" vividas pelo herói tem como cenário a escola de bruxos.

Ao final de cada um dos livros, Harry Potter retorna à casa dos tios, onde é criado. Todos os volumes contêm uma aventura completa ${ }^{278}$, mas vários "ganchos" são deixados para serem resgatados nos livros seguintes, dando prosseguimento à trama sem que se perca o interesse pela continuação do enredo.

\footnotetext{
276 Idem, p. 85. ["I think book seven will be (the biggest). Seven's going to be like the Encyclopaedia Britannica, because l'm going to say goodbye"].

277 Como a história se passa na Inglaterra, esse período compreende os meses de julho e agosto, correspondentes ao verão europeu. $\mathrm{O}$ ano letivo inglês tem início em setembro e termina em junho.

${ }^{278}$ Diferentemente da saga de O Senhor dos Anéis, de J. R. Tolkien, por exemplo, em que um livro é continuação do outro e a história só se completa com os três volumes juntos, a série Harry Potter traz "capítulos" completos de uma única aventura e os volumes podem ser lidos de forma independente, embora a falta de ordem na leitura obscureça alguns detalhes importantes, especialmente após o quarto livro.
} 
Até agora foram publicados seis diferentes títulos:

> Harry Potter e a pedra filosofal (1997)

> Harry Potter e a câmara secreta (1998)

> Harry Potter e o prisioneiro de Azkaban (1999)

$>$ Harry Potter e o cálice de fogo (2000)

> Harry Potter e a Ordem da Fênix (2003)

> Harry Potter e o enigma do Príncipe (2005)

O último livro - ainda sem título definido - deve ser lançado entre 2006 e 2007, completando a saga.

\subsubsection{O enredo}

O enredo da série poderia ser resumido da seguinte forma: Harry Potter é um menino órfão que vive com os tios em um pacato subúrbio de uma cidade da Inglaterra e sofre com maus tratos tanto por parte dos tios, que o desprezam, como por parte do primo, que o humilha. Porém assim que completa onze anos de idade, Harry descobre que é um bruxo e é levado para Hogwarts, uma escola de magia e bruxaria situada em um castelo de estilo medieval, com torres, masmorras e passagens secretas. Lá ele conhece muitos outros bruxos, entre amigos e professores, e tem acesso à verdadeira história de seus pais, assassinados pelo cruel Voldemort, o Bruxo das Trevas. Harry Potter passará então a lutar contra esse vilão de várias formas, protagonizando inúmeras aventuras. 


\section{Livro 1}

O primeiro capítulo de Harry Potter e a pedra filosofal é reservado para contar como os pais do pequeno herói sucumbiram à ação do maldoso Lord Voldemort (ou "Aquele-que-não-deve-ser-nomeado"), e como o bebê Harry, o único que fora até então capaz de sobreviver a um ataque do terrível vilão, teve como destino a casa dos detestáveis tios. A narração não é linear e os acontecimentos vão sendo esclarecidos por meio de diálogos e conversas ouvidas pela personagem Válter ${ }^{279}$, tio do protagonista. No segundo capítulo, dez anos se passam, e Harry, às vésperas de completar onze anos de idade, começa a receber cartas que o convidam para freqüentar Hogwarts, a escola de bruxaria onde seus pais também estudaram. Tem início nesse momento a jornada do herói, quando ele assume sua condição de bruxo e - juntamente com os amigos Rony ${ }^{280}$ e Hermione - passa a viver perigosas aventuras. No final do primeiro livro, revela-se finalmente o paradeiro do terrível Bruxo das Trevas, quando Harry o enfrenta sozinho em um compartimento secreto da escola. Nesse ponto da narrativa o vilão nada mais é do que um espírito maligno à procura de forças para se reerguer, fato que ocorrerá somente ao final do quarto volume.

\section{Livro 2}

No segundo livro, Harry Potter e a câmara secreta, entra em cena outro vilão, Lucius Malfoy, seguidor de Lord Voldemort e pai de Draco Malfoy, colega e principal oponente de Harry na escola. Lucius Malfoy consegue introduzir em Hogwarts o diário de Lord Voldemort, um artefato maligno que

\footnotetext{
${ }^{279}$ Vernon, no original.

${ }^{280}$ Ron, no original.
} 
ameaça alunos e liberta um gigantesco basilisco que habitava há tempos o castelo. Ajudado por objetos e seres mágicos, Harry Potter consegue vencer o monstro e destruir o diário, e é cada vez mais admirado por Dumbledore, o mais poderoso bruxo do seu mundo, e diretor de Hogwarts.

\section{Livro 3}

No terceiro livro da série, Harry Potter e o prisioneiro de Azkaban, as atenções se voltam para uma nova personagem secundária na trama: Sirius Black, o padrinho de Harry. Procurado pela polícia, Black é na verdade um bruxo "bom", acusado injustamente de um crime que não cometeu. O herói órfão descobre a existência de seu padrinho e a injustiça cometida contra ele, porém não consegue livrá-lo das falsas acusações. Além disso, o maldoso Rabicho $^{281}$ - um dos mais fiéis seguidores de Lord Voldemort - consegue escapar e promete juntar-se novamente ao seu mestre. Sirius Black é obrigado a fugir, deixando, contudo, a esperança de que Harry nunca mais estaria só.

\section{Livro 4}

Harry Potter e o cálice de fogo traz o herói já entrando na adolescência, mostrando-se apaixonado por uma menina (Cho Chang) e às voltas com inimigos de toda espécie. Neste livro há a inserção de várias personagens novas, vindas de outros países e encontrando-se no castelo de Hogwarts para uma importante competição entre os bruxos. Harry Potter é inscrito no torneio contra sua vontade e, após passar por várias situações de risco, consegue finalmente chegar à taça, que, para sua surpresa, era uma

${ }^{281}$ Wormtail, no original. 
armadilha para capturá-lo. Ao tocar o troféu de campeão, Harry é transportado magicamente do castelo de Hogwarts para um cemitério, onde Lord Voldemort o aguardava para que seu sangue pudesse fazer parte de um ritual, de onde ressurgiria o Bruxo das Trevas. Apesar da desgastante batalha travada contra o vilão, Harry consegue escapar, mas não é capaz de evitar o retorno de Voldemort ao mundo dos bruxos.

\section{Livro 5}

O quinto livro é um dos mais sombrios da série, e o maior até agora publicado (702 páginas). Em Harry Potter e a Ordem da Fênix, o herói - agora em plena adolescência - vê seus primeiros desejos amorosos frustrados, tem a vida escolar atormentada pelos professores Snape e Umbridge, além de pouco contar com a ajuda do mago Dumbledore, seu protetor. Para seu desespero, vê seu único refúgio - o padrinho e amigo Sirius Black - ser atacado e morto por uma das seguidoras de Voldemort. Sentindo-se culpado pela morte do padrinho, Harry Potter vive um dos piores momentos de sua vida, porém finalmente o mundo dos bruxos começa a acreditar em sua palavra, admitindo o ressurgimento do vilão e preparando-se para a batalha contra as artes das trevas.

\section{Livro 6}

Em Harry Potter e o enigma do Príncipe, uma boa parte da narrativa acontece em flashback. Por meio de pequenas e esparsas lembranças guardadas em um lugar mágico - uma penseira -, de onde é possível resgatálas, Harry Potter tem acesso a vários episódios da infância e da adolescência 
de seu pior inimigo, Lord Voldemort. É por meio dessas lembranças e da reconstrução do percurso do vilão que Dumbledore - neste livro, bem mais presente do que no anterior - pretende ensinar a Harry a melhor maneira de se defender. Harry e Dumbledore descobrem que o Bruxo das Trevas dividiu sua própria alma em sete fragmentos e somente voltará a ser mortal quando todas essas frações tiverem sido destruídas. No entanto, enquanto investiga o passado de Voldemort, Dumbledore descuida-se do presente e cai em uma armadilha montada por Draco Malfoy e Snape, a serviço do Bruxo das Trevas. Dumbledore é assassinado na presença de Harry, que, imobilizado, nada pôde fazer. Nem o amor correspondido de sua namorada, Gina Wesley ${ }^{282}$, aplaca seu sofrimento por mais uma perda. Mais órfão do que nunca, ao herói resta apenas a quase impossível missão de derrotar de uma vez por todas seu pior inimigo, desta vez sem contar com nenhum tipo de proteção.

\section{Livro 7 - Expectativas}

O sétimo livro da série Harry Potter estava destinado a trazer o sétimo e último ano de Harry na escola de magia e bruxaria Hogwarts. Porém há um suspense deixado pela autora ao final do sexto livro: se a escola reabrirá ou não, após a morte do diretor, Dumbledore. Tudo leva a crer, porém, que, neste derradeiro capítulo, Harry vença de uma forma definitiva o maldoso Lord Voldemort; que complete seus estudos em Hogwarts, que possa enfim assumir o amor verdadeiro ao lado de Gina Wesley e, como um bom conto de fadas, que todos vivam "felizes para sempre". É o que se espera, no entanto algumas surpresas podem ter sido reservadas pela autora. É provável, por exemplo, que

\footnotetext{
${ }^{282}$ Giny, no original.
} 
haja outras mortes no caminho de Harry, como uma forma de enaltecer ainda mais a vitória do herói. Há quem acredite que o próprio Harry Potter possa morrer no capítulo final ao enfrentar e derrotar o vilão, como um auto-sacrifício em prol de um bem comum, o que - embora não seja freqüente em obras destinadas à infância e à juventude - não seria de todo atípico para o destino de um herói à moda antiga.

\subsubsection{Desdobramentos}

Inspirados nos quatro primeiros romances da série, quatro longasmetragens já foram realizados até agora. Embora contestados por alguns fãs mais fervorosos, os filmes trazem os episódios mais importantes de cada um dos respectivos livros, e têm recebido boas críticas tanto da mídia quanto da própria autora, que faz questão de supervisionar o trabalho de adaptação.

Para todos os filmes, o elenco principal de atores mirins foi mantido, o que é um fato interessante visto que os atores cresceram e deixaram de ser crianças para se tornarem adolescentes encorpados, assim como também acontece com seus personagens nos livros (Figura 2).
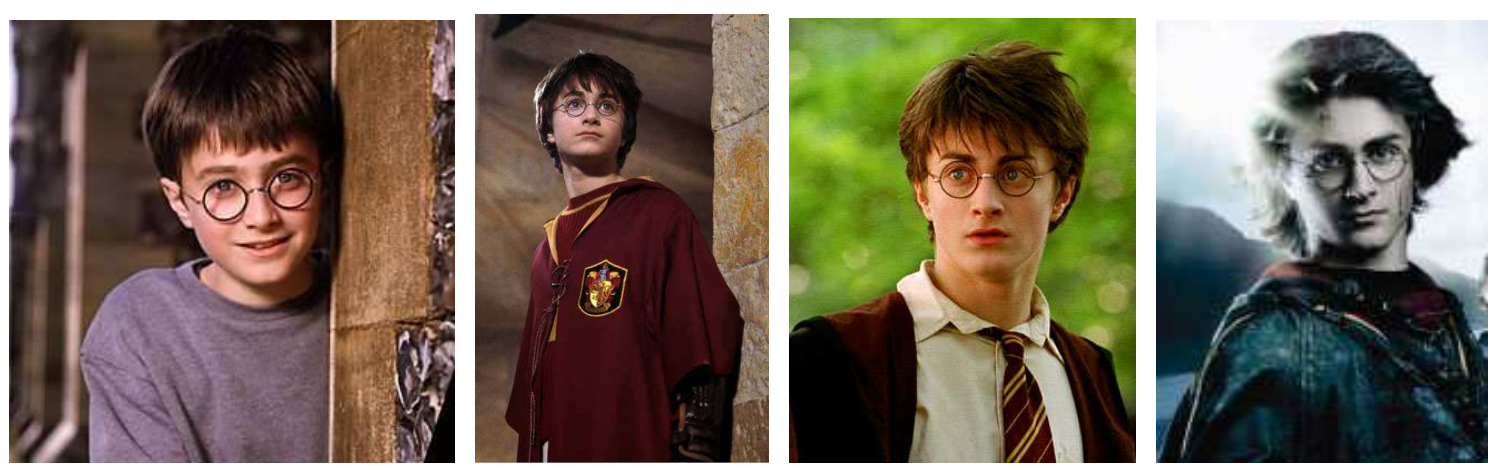

Figura 2 - Daniel Hadcliff (Harry Potter): crescendo juntamente com o personagem (alusão aos quatro primeiros livros da autora J.K. Rowling: Harry Potter e a pedra filosofal, 2001; Harry Potter e a câmara secreta, 2002; Harry Potter e o prisioneiro de Azkaban, 2004, e Harry Potter e o cálice de fogo, 2005). 
Além dos longas-metragens, quatro games também já foram lançados no mercado, baseados nos quatro primeiros livros e filmes. A "marca" Harry Potter expandiu-se ainda para brinquedos, roupas, acessórios e uma profusão de materiais escolares e outros produtos.

Apesar da grande divulgação e difusão desses produtos de consumo, cada vez mais os críticos e os leigos têm voltado atrás e atribuído significativo valor literário à criação de Rowling, que não por acaso tem alcançado patamares jamais imaginados para uma literatura destinada ao público jovem:

É preciso desconhecer totalmente os meandros do fenômeno para pensar que seus leitores o escolheram apenas graças à publicidade ou à benevolência da mídia. Não se pode esquecer que não houve uma campanha publicitária prévia que tivesse alçado esses livros à condição de objetos de consumo desejáveis. Os responsáveis iniciais foram os leitores. Depois de constatado o imenso impacto de público, o mercado acordou e absorveu o fenômeno, então vieram os brinquedos, os filmes e os produtos com a marca da série $^{283}$.

Classificado algumas vezes como um "conto de fadas moderno", Harry Potter tem sido alvo de estudos e ensaios que justifiquem ou tentem explicar o seu grande sucesso.

Em um desses estudos, Isabelle Smadja, autora do livro Harry Potter: as razões do sucesso, tenta encontrar respostas para essa questão, partindo do seguinte ponto de vista:

Harry Potter não é uma obra que faz a apologia do mistério ou do irracional, mas também não é um livro que se apóia, para expor sua moral, somente na racionalidade. Harry Potter é um conto de fadas, mesmo que a autora tenha preferido trocar o disfarce da fada pela capa do mágico. E, como em um conto de fadas, o ensinamento que transmite baseia sua matéria nos mistérios do inconsciente e do imaginário ${ }^{284}$.

${ }^{283}$ CORSO, D. \& CORSO, M. Op.cit., p. 254.

${ }^{284}$ SMADJA, I. Harry Potter: as razões do sucesso. Trad. Ângela R. Viana e Antônio M. Guimarães. Rio de Janeiro, Contraponto, 2004, p. 10. 
Nas considerações finais desta dissertação, após a análise de personagens provenientes de outras mídias, procuraremos retomar o debate acerca das "razões do sucesso" da série e discutir esse ponto de vista. 


\subsubsection{O órfão nos quadrinhos}

As histórias em quadrinhos (HQ) surgiram nas primeiras décadas do século XX como "tiras" em jornais e tinham uma função meramente cômica, além de um espaço reduzido. Para resolver em parte o problema da limitação gráfica foram criadas as "tiras seriadas", como se fossem capítulos de uma única HQ. Em 1929 apareceram os primeiros comic books (revistas em quadrinhos), e começou a ser veiculado o gênero de aventura, com $\mathrm{HQ}$ mais elaboradas, contendo cenários mais realistas e desenhos menos caricaturados, protagonizadas por heróis:

O gênero da aventura vem substituir as histórias em quadrinhos com desenhos caricaturais e histórias cômicas, infantis e/ ou familiares que predominam até o final da década de 20. (...) O novo gênero traz um desenho realista que é necessário com a renovação temática ocorrida. (...) O crescimento do número de personagens, os ambientes em que se desenrolam as aventuras, os atributos físicos típicos dos heróis e vilões, entre outros elementos, promovem a necessidade de um desenho realista. (...) O gênero aventura se caracteriza pela aventura, uma narrativa seqüencial longa, realizada por um herói, um indivíduo com capacidades humanas extraordinárias (força física, atributos morais, etc.), que deve realizar uma missão: lutar pela justiça ${ }^{285}$.

Os Estados Unidos foram os pioneiros na criação desse novo gênero, a HQ de aventura. Um dos primeiros heróis a "estrear" nesse suporte foi o já citado Tarzan ${ }^{286}$, de Edgard Rice Burroughs:

${ }^{285}$ VIANA, N. "A era da aventura no mundo dos quadrinhos". IN: Revista Espaço Acadêmico, n. 35. Abril, 2004, pp. 1-4. Disponível em <http://www.espacoacademico.com.br/035/35cviana. $\mathrm{htm}>$ Acesso em 11/12/2005.

${ }^{286}$ Nascido na literatura em 1912, já havia sido adaptado para o cinema em 1918 e ganhou a primeira versão em quadrinhos em 1929. 
Em 1929, aparece, nos EUA, Tarzan e Buck Rogers. Nos anos seguintes vão surgindo novos heróis: Príncipe Valente, Dick Tracy, Flash Gordon, Zorro (Cowboy), Mandrake, Fantasma, entre outros $^{287}$.

A partir daí muitos heróis de quadrinhos passaram a ter habilidades e talentos especiais, além de assumirem identidades secretas. Por essas características, acabaram por receber o prefixo "super".

A personagem mais emblemática e precursora dos chamados "superheróis" é, sem dúvida, o "Homem de Aço", mais conhecido como Superman ou "Super-Homem", criado em $1938^{288}$, que até hoje - quase setenta anos depois - continua a fazer parte do imaginário, das brincadeiras e fantasias de crianças em todo o mundo.

Morris \& Morris, em seu livro Super-heróis e a filosofia ${ }^{289}$, afirmam que "um dos mais notáveis desenvolvimentos na cultura pop da atualidade é o forte ressurgimento do super-herói como ícone cultural e de entretenimento". Acrescentam ainda:

Não são muitos os personagens fictícios que alcançaram o reconhecimento internacional do Super-Homem e do Batman. Esses dois titãs dos quadrinhos inspiraram programas de rádio e de televisão, filmes e musicais desde que surgiram, no fim da década de 1930. Em quase todo o mundo você pode ver alguém usando uma camiseta do Super-Homem ou do Batman, e nas mais extraordinárias circunstâncias ${ }^{290}$.

Para os autores, esse reconhecimento público ao herói dos quadrinhos deve-se em parte pelo fato de essas personagens e histórias não representarem apenas mero entretenimento, mas por trazerem em seu âmago

\footnotetext{
${ }^{287}$ VIANA, N. Op. cit., p. 5.

${ }^{288}$ Mais à frente outras informações serão fornecidas a respeito do Super-Homem.

${ }^{289}$ MORRIS, T. \& MORRIS, M. Super-heróis e a filosofia. Trad. Marcos Leal. São Paulo, Madras, 2005.

${ }^{290}$ Idem, pp. 9-10.
} 
questões referentes à ética, à justiça, às virtudes clássicas, como por exemplo

a coragem, entre outros temas importantes:

Até o observador mais casual sabe que essas histórias são cheias de ação, aventura, suspense e um incrível trabalho de arte. Mas pouquíssimas pessoas percebem que elas também merecem séria atenção intelectual, por suas fascinantes apresentações de temas e idéias com profundidade filosófica. (...) As melhores histórias em quadrinhos de super-heróis, além de divertirem, introduzem e abordam de forma vívida algumas das questões mais interessantes e importantes enfrentadas por todo ser humano - questões referentes à ética, à responsabilidade pessoal e social, à justiça, ao crime e ao castigo, à mente e às emoções humanas, à identidade pessoal, à alma, à noção de destino, ao sentido de nossa vida, ao que pensamos da ciência e da natureza, ao papel da fé na aspereza deste mundo, à importância da amizade, ao significado do amor, à natureza de uma família, às virtudes clássicas como coragem e muitos outros temas importantes. Já estava na hora de pelo menos as melhores histórias em quadrinhos serem reconhecidas também pelo intrigante modo como levantam e debatem essas prementes questões humanas ${ }^{291}$.

Entre essas "prementes questões humanas", sem dúvida a orfandade é um dos temas mais recorrentes nas HQ cujos protagonistas são super-heróis. Como apontado na análise do órfão na literatura, na ausência dos pais, o herói tem mais liberdade de ação e de escolha; sente-se impelido a agir sem retaliação ou censura, pode tomar decisões por conta própria sem ter que dar satisfações a ninguém. Por outro lado, porém, reside no órfão um sentimento de abandono, de solidão, de isolamento, de alguém que tem de buscar um sentido para a vida fora de si mesmo, uma vez que the foram "roubados" os alicerces de sua morada, a sua sustentação. Muitas dessas personagens refugiam-se em cavernas e esconderijos secretos, fazem uso de máscaras e reinventam sua própria identidade, talvez como uma forma de renascimento para a vida após um grande trauma sofrido.

${ }^{291}$ Idem, p. 11. 
Porém ao contrário de muitos dos heróis da literatura analisados no capítulo anterior, a grande maioria dos super-heróis aparece para o leitor já na idade adulta (ou próximo dela). Em alguns casos há menção da orfandade do herói somente por meio de flashbacks ou de diálogos entre personagens. O fato é que a orfandade do super-herói - salvo exceções - ocorre de maneira geral na sua infância, ocasionando profundas mudanças em seu modo de ser, que se refletirão mais tarde em suas atitudes e na postura que o órfão toma frente a um desafio ou obstáculo.

Para Loeb \& Morris, um dos fatores que aproxima os super-heróis de seus leitores e faz com que as $H Q$ de aventura permaneçam entre as preferências de leitura de muitas crianças, jovens e adultos até hoje é a maneira como o medo e outros sentimentos difíceis de serem lidados são abordados nessas narrativas:

Não precisamos dizer que os quadrinhos de super-heróis têm a intenção de ser instrutivos ou de natureza moralista. Às vezes, são só divertidos. Mas é sensato sugerir que os super-heróis existem há tanto tempo e continuam sendo tão populares, em parte, porque falam à nossa natureza, bem como às nossas aspirações e aos nossos medos. Todos nós queremos ser importantes, ter algum impacto neste mundo e ser reconhecidos por esse impacto. Os super-heróis mantêm viva a chama em nosso coração, na medida em que ponderamos o sentido de sua missão e os vemos vivê-la. Mas suas histórias também falam aos nossos medos, e de modo igualmente importante ${ }^{292}$.

A partir do momento em que o super-herói encontra adversidades e consegue superá-las, apesar de todos os obstáculos possíveis que são colocados em seu caminho, esse triunfo pode servir de inspiração para muitas pessoas agirem da forma correta, mesmo que esse não seja, necessariamente, o caminho mais fácil.

${ }^{292}$ LOEB, J. \& MORRIS, T. "Heróis e Super-heróis" in: MORRIS \& MORRIS, Op. cit., p. 28. 
Loeb \& Morris acreditam que, muitas vezes, não são os superpoderes que fazem diferença na vida do super-herói, mas suas virtudes "clássicas", como determinação, coragem, persistência, autoconfiança e criatividade:

Eles não aceitam derrota. Nunca desistem. Eles acreditam em si mesmos e em sua causa, e não medem esforços para atingir suas metas. Mostrando-nos que até pessoas muito poderosas têm de lutar e se empenhar na luta para vencer, eles nos ajudam a lidar com os medos que enfrentamos em relação às nossas perspectivas no mundo 293 .

Assim como o herói do conto popular, muitos super-heróis iniciam sua trajetória rumo ao estabelecimento da justiça após uma desgraça, podendo essa "desgraça" se resumir, inclusive, na morte ou desaparecimento dos próprios pais $^{294}$. É o que acontece, por exemplo, com o Fantasma, com Batman e Robin, com o Homem-Aranha, apenas para citar alguns. Iniciaremos, então, este breve histórico dos super-heróis de HQ por um dos maiores ícones dessa categoria de personagens, o também órfão Super-Homem.

A publicação da primeira $H Q$ do Super-Homem (1938) inaugurou "uma nova era nas histórias em quadrinhos: a era dos super-heróis"295. Nascido no planeta Kripton, o Super-Homem, ainda bebê, é colocado por seu pai em um foguete rumo à Terra, momentos antes da explosão do planeta. A criança é encontrada e adotada por um casal de idade, e ganha o nome de Clark Kent. Ainda menino, começa a mostrar seus superpoderes, como sua força descomunal, velocidade, visão de raios-x, capacidade para voar, entre outros.

\footnotetext{
${ }^{293}$ Idem, ibidem.

294 Como analisamos no primeiro capítulo desta dissertação, em muitos contos populares o fator que desencadeia a ação da personagem central é o estabelecimento de uma desgraça, que pode ser, como citamos, a própria orfandade do herói.

295 Superman, publicado em junho de 1938 na revista Action Comics, da Nacional, foi criado por dois jovens universitários, Jerome Siegel (textos) e Joe Shuster (desenhos). CAVALCANTI, I. A. Esses incríveis heróis de papel. São Paulo, Mater, s/d, p. 108.
} 
São essas e outras características que o fazem super. Porém é a integridade, o altruísmo e o desprendimento com relação à glória pessoal que o fazem herói.

Batman (1939) $)^{296}$ - que aparece no cenário das HQ um ano depois de Super-Homem - já não possui tantos poderes inatos. É forte e corajoso, possui utensílios inteligentes que lhe conferem habilidade fora do comum, mas não é sobre-humano como seu precedente. Mais do que a justiça, o que impulsiona primeiramente o Homem-Morcego para o combate ao crime é a vingança. A história do super-herói começa quando o então menino Bruce Wayne presencia o assassinato dos pais (Figura 3). Naquela idade, porém, o órfão assustado e medroso não demonstrava qualquer semelhança com a figura forte e destemida que iria se tornar mais tarde.

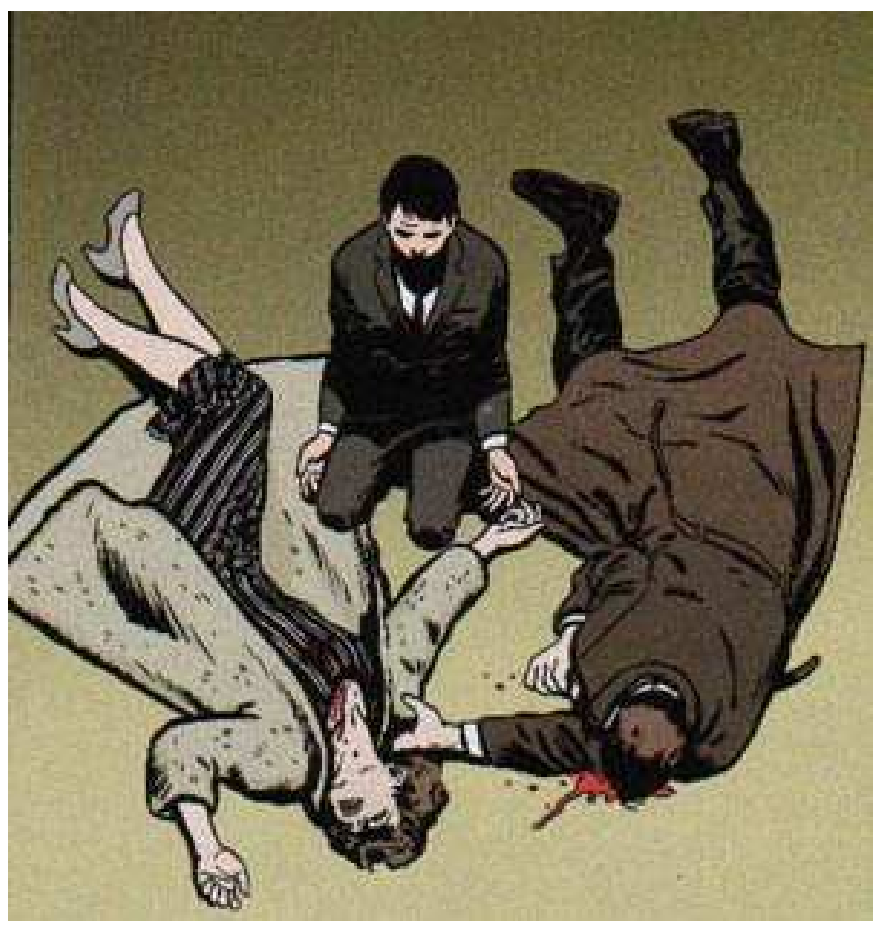

Figura 3 - llustração que representa o assassinato dos pais de Bruce Wayne - Batman -, testemunhado pelo menino (In: MILLER, F. \& MAZZUCCHELLI, D. Batman Ano Um. Rio de Janeiro, Panini, 2005).

${ }^{296}$ Batman, ou o Homem-Morcego, nome que não vingou no Brasil, foi lançado nos EUA em maio de 1939 na revista Detective Comics da National. Com texto de Bill Finger e desenhos de Bob Kane, Batman teria sido inspirado no herói Bat Black, criação de Murray Leinster, um justiceiro das revistas policiais americanas dos anos 30 (CAVALCANTI, I. A. Op. cit., pp. 16-17). 
No ano seguinte ao da estréia de Batman nos quadrinhos, aparece seu inseparável companheiro, o também órfão Dick Grayson, sob o pseudônimo de Robin:

A história original de Robin começou no circo. John e Mary Grayson, conhecidos como "Os Graysons Voadores", estavam fazendo um número no trapézio quando a corda quebrou, eles caíram e morreram. O filho do casal, Dick Grayson, testemunhou a morte dos pais, como acontecera com Bruce Wayne quando era criança. Bruce estava na platéia quando o acidente ocorreu e logo sentiu muita pena de Dick. O jovem órfão não tinha para onde ir, e Bruce foi magnânimo e adotou-o. Dick logo descobriu que a morte de seus pais não fora acidental, mas planejada. Bruce sentiu que a resultante raiva, tristeza e confusão de Dick pelo terrível crime deveriam ser concentradas em uma direção positiva. Para orientar a vida do rapaz nos passos certos ele revelou-lhe sua identidade como Batman e ofereceu-se para treinar Dick no combate ao crime. E foi assim que Dick Grayson se tornou Robin ${ }^{297}$.

Apesar da amizade entre os dois e da eficiência da dupla no combate ao crime, Batman ainda é considerado um dos mais solitários entre os superheróis $^{298}$. Segundo Morris, essa característica do herói está diretamente ligada à sua orfandade:

O que impede Batman de ter o que Aristóteles considerava uma amizade completa? Não são seus altos padrões. Não é uma falha das outras pessoas. Uma boa parte da responsabilidade parece estar bem diante de seu nariz. Uma amizade assim requer um grande envolvimento pessoal. Isso é quase impossível para Batman depois da promessa que ele fez a seus pais mortos. Ele dedica tanto tempo e esforço à missão de combater o crime que não tem muito tempo para os amigos (...) No recente filme Hush, Batman confessa à Mulher-Gato sua incapacidade de manter amizades íntimas (...): “ Eu... Eu não sou muito bom nisso. Ter amigos. Parceiros. Tudo termina em traição e morte. Se é que algum dia eu já tive isso, perdi na noite em que meus pais foram assassinados ${ }^{299}$.

\footnotetext{
${ }^{297}$ MORRIS, M. "Batman e amigos: Aristóteles e o círculo interno do cavaleiro das trevas" IN: MORRIS, T. \& MORRIS, M. Op. cit, p. 110.

${ }^{298}$ Idem, p. 108.

${ }^{299}$ Idem, pp. 118-9.
} 
Ainda anterior a Batman e Super-Homem, o Fantasma ${ }^{300}$ também traz em suas aventuras o estigma do órfão. $\mathrm{Na} H Q$ original, o navio onde um importante lorde inglês viajava com seu filho é abordado por piratas e não resiste ao ataque, submergindo na costa da Índia. Único sobrevivente do naufrágio, o jovem Walker jura, com a caveira do pai nas mãos, dedicar toda a sua vida ao combate à pirataria e ao crime. Promete ainda que seus filhos e netos, geração após geração, seguirão a mesma sina, não deixando esmorecer a dinastia "Fantasma". Ao contrário de outros super-heróis, o Fantasma não possui superpoderes e deve, além de lutar pela justiça, constituir sua própria família, de modo a garantir a continuidade da "lenda". Como cada sucessor usa sempre a mesma vestimenta e habita o mesmo lugar - uma caverna cuja entrada tem a forma de uma caveira -, há quem acredite ser o Fantasma "imortal". Embora sempre abrigando diferentes identidades sob a máscara e a roupa justa, o Fantasma é sempre órfão, uma vez que herda a sina do pai.

Muitos outros super-heróis poderiam também fazer parte desse rol, como por exemplo o Demolidor (Daredevil, 1940) (01, $^{301}$ pseudônimo do jovem órfão e cego Matt Murdock, que tem o pai assassinado quando ainda é menino (Figura 4) ou o Capitão Marvell (Captain Marvell, 1940) ${ }^{302}$, pseudônimo do órfão Billy Batson e conhecido pelo inconfundível grito "SHAZAM" ${ }^{303}$.

300 The Phantom. Publicada pela primeira vez como tira em fevereiro de 1936 no American Journal, com textos de Lee Falk e desenhos de Ray Moore, a série fez enorme sucesso, ganhando sua própria revista e adaptações para o cinema e televisão (CAVALCANTI, I. A. Op. cit., p. 52).

301 Daredevil, criação de Jack Cole, esta HQ teve uma recente adaptação para o cinema (Demolidor, o homem sem medo, 2003).

302 Captain Marvell, criação de Otto e Earl Binder.

${ }^{303}$ O grito "SHAZAM" é uma referência aos deuses e heróis da mitologia clássica: Salomão (sabedoria), Hércules (força); Atlas (resistência); Zeus (poder); Aquiles (coragem); Mercúrio (velocidade). (CAVALCANTI, I. A. Op. cit., p. 29). 


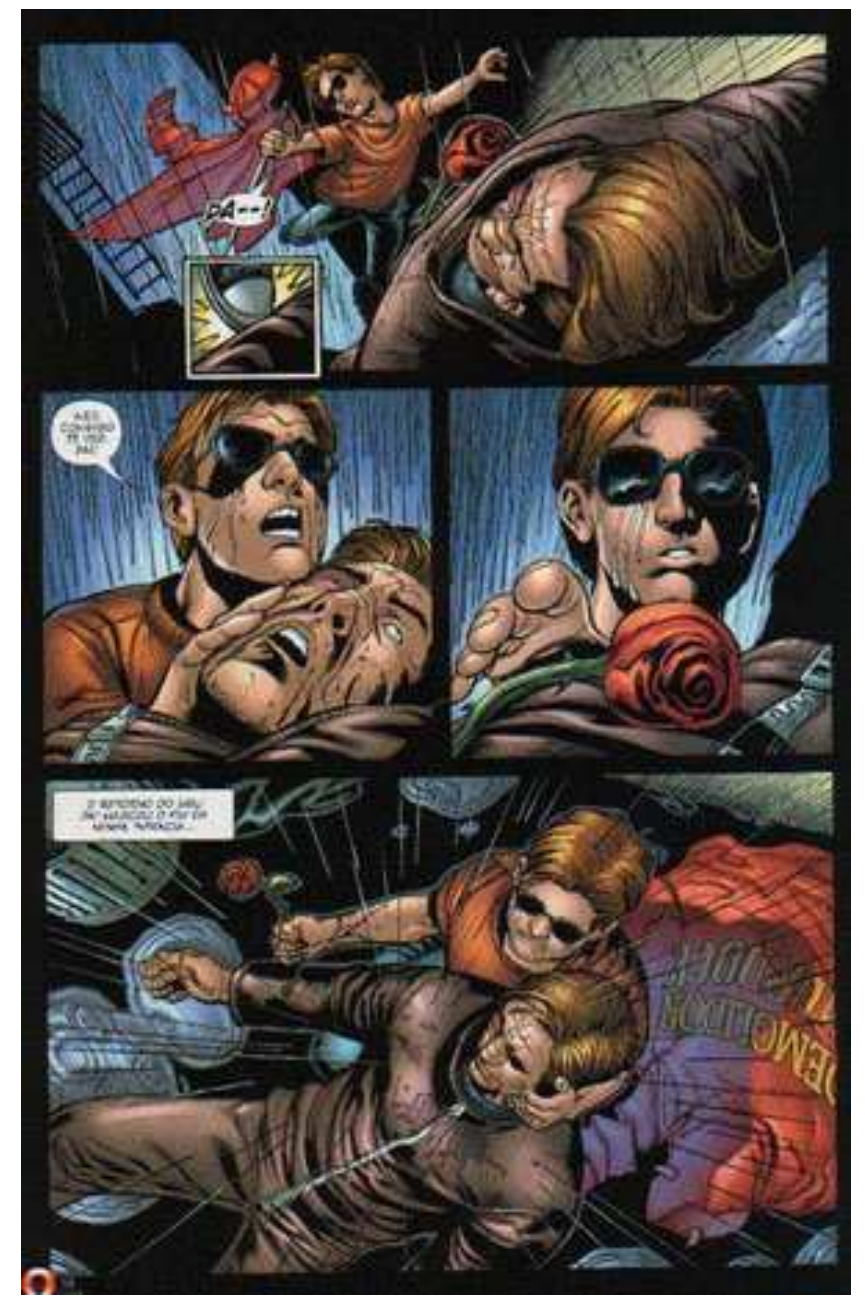

Figura 4 - Seqüência de quadrinhos baseada no longa-metragem de 2003 em que o menino cego Matt Murdock - futuro Demolidor - encontra o pai assassinado (In: JONES, B.; GARCIA, M. \& HANNA, S. D. Demolidor - O homem sem medo. Rio de Janeiro, Panini, 2003).

Porém o super-herói escolhido para representar essa categoria de personagens $^{304}$ na análise que faremos a seguir é por muitos considerado um "super-anti-herói”, uma vez que, apesar de todos os superpoderes que possui, lida com um sem-número de problemas pessoais típicos da adolescência: o Homem-Aranha, ou Spiderman (1962) ${ }^{305}$, pseudônimo de Peter Parker.

${ }^{304}$ Limitamos este histórico do órfão nos quadrinhos aos super-heróis, não desprezando o fato de haver muitas outras personagens passíveis de análise, como por exemplo as criações Disney, e o universo de Maurício de Sousa, entre outras, que fogem, porém, ao escopo desta dissertação.

${ }^{305}$ Criação de Stan Lee, com desenhos originais de Steve Ditko. Outras informações sobre o Spiderman serão dadas nas páginas seguintes. 


\subsubsection{Peter Parker e os quadrinhos - o suporte original}

Nem todos os heróis possuem a relativa serenidade do Super-Homem. Talvez seja por isso que os quadrinhos e os filmes do Homem-Aranha tenham um sucesso extraordinário. O Homem-Aranha nos oferece um super-herói com quem nos podemos identificar - Peter Parker é um jovem que luta contra as tentações humanas comuns, bem como os entraves da adolescência.

(C. Stephen Evans) $)^{306}$

Após criar personagens de bastante sucesso, como o Quarteto Fantástico (1961), o poderoso Thor (1962), e o incrível Hulk (1962), Stan Lee $\left({ }^{*} 1922\right)^{307}$ resolveu enfrentar a incredulidade de seus editores e apostar no sucesso de um herói às avessas, baseado na figura de um adolescente desajeitado e inseguro, cheio de dúvidas e frustrações. Nascia, desse modo, em agosto de 1962, Spiderman, ou o Homem-Aranha, destinado a ser o superherói preferido de muitas crianças e jovens, durante muitas gerações.

O próprio Stan Lee comenta os motivos que levaram alguns de seus amigos a desencorajá-lo da criação da personagem, entre eles o fato de que um herói teria que ser necessariamente forte e bonito; não poderia apresentar problemas pessoais, nem ser um adolescente confuso e atrapalhado, além do fato de as pessoas geralmente sentirem repulsa por aranhas ${ }^{308}$. No entanto os prognósticos não se confirmaram e o Homem-Aranha mostrou-se um sucesso

${ }^{306}$ EVANS, C. S. "Por que os super-heróis devem ser bons? Homem-Aranha, os X-Men e o duplo perigo de Kierkegaard" IN: MORRIS, M. \& MORRIS, T. Op. cit., p. 161.

307 Stanley Martin Lieber, conhecido como Stan Lee, nasceu em Nova York em fevereiro de 1922.

${ }^{308}$ LEE, S. "Introduction" in: LEE, S. \& DITKO, S. The amazing fantasy. Nova York, Marvel, 1987. 
que perdura até hoje, mais de quarenta anos depois do seu primeiro aparecimento.

A $\mathrm{HQ}$ que trazia a primeira aventura do Homem-Aranha foi veiculada no último número da revista Amazing Fantasy da Marvel, em agosto de 1962. Devido ao sucesso imediato, a personagem ganhou sua própria revista já no início do ano seguinte, The amazing Spider-Man, com roteiro de Stan Lee, e ilustrações de Steve Ditko. Foram lançadas em 1963 seis revistas bimestrais, tendo participado das primeiras edições os argumentistas Johnny Dee, Art Simek, John Duffy e S. Rosen. Os roteiros incluíram também a presença de outros heróis, como o já criado Quarteto Fantástico (Stan Lee, 1961) e vários vilões, como o Dr. Octopus e o Homem-Areia (Sandman).

\subsubsection{A obra}

Tratando-se de uma personagem concebida para HQ, a continuidade da série depois de seu lançamento, em 1962, era esperada e a saga de Peter Parker não esmoreceu.

Após a primeira seqüência de publicações de sucesso, as $H Q$ do super-herói foram retomadas em 1966, ganhando novos argumentos e contando com uma recém-formada equipe de desenhistas e roteiristas. Alguns anos mais tarde, surgiram outras duas séries, em 1972 e em 1976, esta última com o título Peter Parker, o espetacular Homem-Aranha. No final da década de 80, o desenho ganhou mais agilidade e realismo, tornando-se o principal produto de vendas da Marvel Comics.

Hoje, no Brasil, a revista em quadrinhos Homem-Aranha é editada pela Panini Comics e tem periodicidade mensal. 


\subsubsection{O enredo}

Diferentemente dos heróis da literatura, em que há um enredo planejado e "fechado", mesmo que composto por vários capítulos ou volumes, como em Harry Potter, os heróis dos quadrinhos fazem parte das histórias seriadas, em que não há um enredo único, uma vez que o protagonista sempre participará de uma nova aventura, até que o ciclo se encerre, em decorrência da "aposentadoria" ou morte de um autor ou do fim premeditado da personagem, por opção de seus criadores.

\section{$H Q$ original}

O cenário utilizado para construir a história de Peter Parker não é uma cidade imaginária como Gotham City, nem planetas distantes como Kripton ${ }^{309}$, mas a conhecida Nova York dos anos 1960.

O primeiro quadrinho de Homem-Aranha apresenta-nos o adolescente Peter Parker sendo alvo de comentários maldosos e gozações por parte dos colegas. O segundo, mostra o seu contraponto: o cuidado de tio Ben e tia May para com o sobrinho órfão de quem cuidam como se fosse seu próprio filho.

A partir dessas primeiras cenas constrói-se o perfil da personagem: um adolescente estudioso, mas considerado "nerd" ${ }^{310}$ pelos colegas; um jovem que busca sua auto-afirmação sem contar com nenhuma qualidade especial: não é do tipo atlético ou atraente, pelo contrário, é "baixinho", usa óculos; não tem dinheiro, roupas bonitas ou ao menos um carro para se exibir para as

${ }^{309}$ Gotham City é uma cidade inventada onde vive Batman; Kripton é o planeta imaginário onde nasceu Super-Homem.

${ }^{310}$ No original, muitas vezes os colegas referem-se a Peter Parker como "bookworm" (traça de livros/ aficionado por livros), que poderia ser traduzido em português como "C.D.F.". Hoje, no entanto, é mais comum entre os jovens o termo "nerd", utilizado para designar aqueles que só pensam em estudar sem dar muito valor à vida social e também aos indivíduos considerados "chatos", de quem todos preferem se afastar. 
meninas. Além disso parece não saber dançar e, diferentemente de sua turma, mostra entusiasmo e aplicação nos estudos.

Para tentar fazer amizades, Peter Parker convida os colegas para uma mostra científica, mas sua idéia é logo desprezada por todos. Mesmo sozinho e chateado, ele vai à exposição, e justamente ali sucede o fato que mudaria para sempre sua vida: durante um experimento, uma aranha despercebidamente é exposta a uma superdosagem de radiação e antes de morrer pica a mão do jovem Peter Parker. Sentindo-se estranho, o adolescente vai para casa, e já no caminho começa a perceber mudanças em seu corpo: ganha habilidade para escalar paredes, sua visão fica perfeita e sua força e agilidade tornam-se incomuns.

Sentindo-se satisfeito com sua nova forma de ser, o órfão começa a imaginar como usar seus novos atributos para o seu próprio bem, e, principalmente, como poderia ganhar dinheiro com eles. Para testar seus poderes, Peter inscreve-se para participar de uma luta livre cujo vencedor ganharia cem dólares. Para não ser reconhecido, usa roupas velhas e uma espécie de lenço sobre o rosto. Com o sucesso na luta, além do dinheiro, o adolescente ganha também um convite para protagonizar um show em uma emissora de televisão. Já em casa, decide incrementar sua personagem, desenvolvendo um mecanismo que se prende aos pulsos para conseguir soltar uma "teia" e confeccionando uma nova máscara e uma fantasia completa, atribuindo a si mesmo o nome "Spiderman".

Já no primeiro show o misterioso mascarado impressiona o auditório e é assediado por repórteres e curiosos. Sentindo-se superior às outras pessoas, Peter Parker esnoba seus fãs e se recusa a atender o segurança do local, 
quando este pede sua ajuda para prender um ladrão em fuga. Peter torna-se egoísta e vingativo, procurando tirar vantagens de seus novos poderes e decidindo não se importar com mais nada, além de seu próprio sucesso e bemestar.

Em uma das noites seguintes, porém, ao voltar do seu show, Peter depara-se com um carro da polícia em frente a sua casa. O policial dá ao rapaz a triste notícia da morte de seu tio, que teria surpreendido um assaltante dentro de casa e, por isso, fora baleado. Desesperado, o jovem coloca suas vestes de Homem-Aranha e sai em busca do culpado, a quem encontra rapidamente. Para sua surpresa e arrependimento, ele reconhece no assassino do tio o ladrão que deixara escapar dias antes, por conta de sua arrogância e insolência.

Os últimos quadrinhos da primeira $\mathrm{HQ}$ de Spiderman (Figura 5) mostram o sentimento de culpa que cresce dentro do jovem, aumentando sua solidão e sua responsabilidade ("com grande poder também deve vir grande responsabilidade"311).

O episódio da morte do tio promove, assim, a transformação de um jovem exibicionista em um legendário super-herói, que a cada nova aventura tentará provar seu valor. O narrador termina a $\mathrm{HQ}$ original com a frase: "assim nasce uma lenda e um novo nome é adicionado à galeria daqueles que fazem o mundo da fantasia o reino mais extraordinário de todos" ${ }^{312}$.

\footnotetext{
311 "At last that in this world, with great power there must also come - great responsibility". (LEE, S. \& DITKO, S. The amazing fantasy. Nova York, Marvel, 1987, p. 13).

312 "And so a legend is born and a new name is added to the roster of those who make the world of fantasy the most exciting realm of all". (LEE, S. \& DITKO, S. The amazing fantasy. Nova York, Marvel, 1987, p. 13).
} 


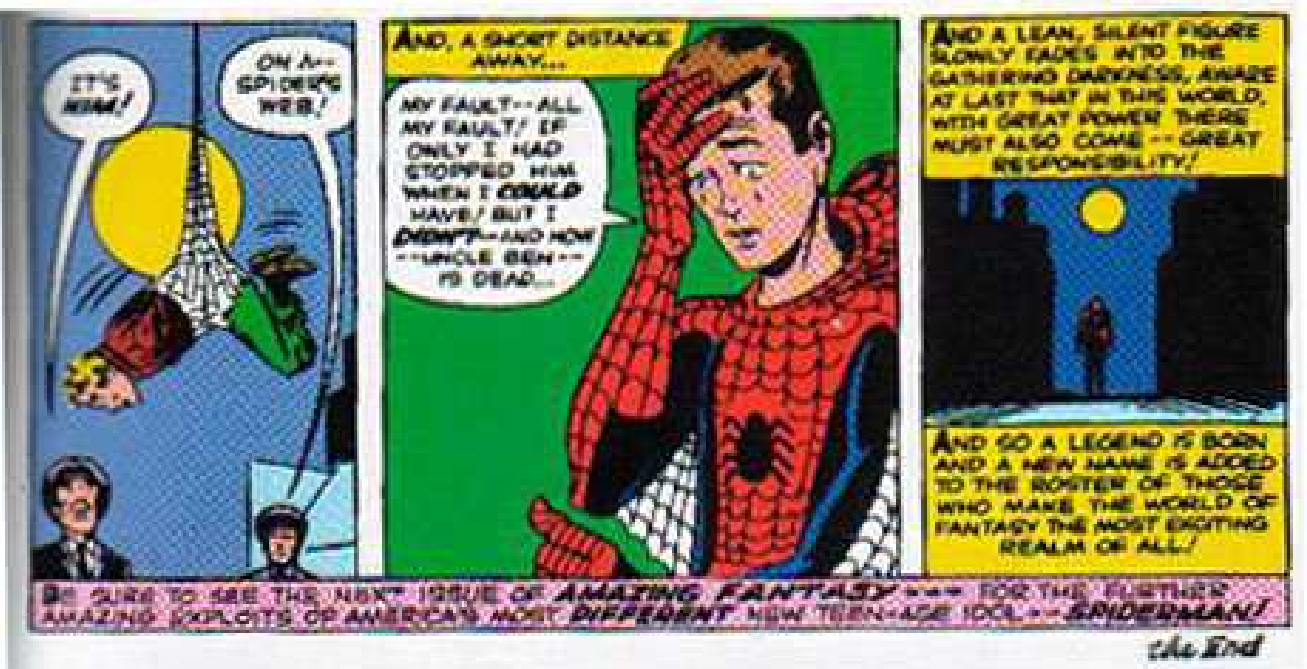

Figura 5 - Seqüência de quadrinhos em que Peter Parker entrega o assassino do tio à polícia e reconhece seu erro, sofrendo com as conseqüências (In: LEE, S. \& DITKO, S. The amazing fantasy. Nova York, Marvel, 1987, p. 13). Reedição do original de 1962.

\section{Segundo episódio}

O primeiro número de The Amazing Spiderman traz duas $\mathrm{HQ}$ completas de Homem-Aranha. Na primeira - intitulada apenas como "SpiderMan”313 - é feita uma rápida retrospectiva de como Peter Parker ganhou seus poderes especiais e de como se deu a morte de tio Ben.

Na seqüência, é mostrada a angústia do adolescente, em ver a tia idosa em situação financeira difícil, e sua decisão em ajudá-la, com suas apresentações na televisão. No entanto, Peter Parker logo se depara com dois problemas: como não pode sacar o cheque em nome de "Spiderman", e também não abre mão da identidade secreta, o jovem não consegue receber nada pelas apresentações. E, para piorar sua situação, J. Jameson, o editor de um jornal sensacionalista, inicia uma verdadeira campanha para acusá-lo de "ameaça à população".

${ }^{313}$ Na própria revista não há padronização quanto à escrita "Spider-Man" ou “Spiderman”. 
Sem dinheiro e sem perspectivas de continuar a explorar seus poderes em exibições para a televisão, Peter Parker tem seu primeiro "trabalho" como super-herói justamente quando o filho de Jameson, um jovem astronauta, tem problemas para controlar sua nave recém-lançada ao espaço. O Homem-Aranha oferece-se para ajudá-lo e, fazendo-se valer de seus superpoderes, consegue salvar a vida do rapaz. Como "recompensa", porém, o herói é novamente acusado por Jameson em seu jornal como sabotador e inimigo da população.

\section{Terceiro episódio}

Ainda na mesma revista, há mais uma $\mathrm{HQ}$ - "Spider-Man versus The Chameleon" ${ }^{314}$-, em que aparece o primeiro inimigo do Homem-Aranha, um bandido chamado "Camaleão", cuja principal arma reside em seus inúmeros disfarces. Também pela primeira vez o novo herói contracena com outros super-heróis: os integrantes do Quarteto Fantástico ${ }^{315}$, também criação de Stan Lee. Após muitos problemas e contratempos, devido à falta de confiança da imprensa e dos artifícios lançados pelo Camaleão, que se faz passar por um falso Homem-Aranha, o super-herói consegue finalmente capturar o bandido e esclarecer a verdade, porém nunca é totalmente compreendido e seus atos são tidos como "tolos" ou "confusos".

Dessa forma o Homem-Aranha vai aos poucos se mostrando um super-herói muito diferente de seus precursores, como os fortes e imbatíveis Super-Homem, Batman ou o próprio Quarteto Fantástico.

\footnotetext{
314 "Homem-Aranha versus O Camaleão"

315 O Quarteto Fantástico (The Fantastic Four, 1961), conhecido também pela sigla FF, é composto, como o próprio nome diz, por quatro integrantes: Reed, que pode transformar-se em qualquer coisa, O Coisa, O Tocha-humana e A Mulher Invisível.
} 
Muitos atribuem o sucesso dessa personagem exatamente à sua fragilidade e ao seu modo modesto e "humano" de ser, seja como o desajeitado adolescente Peter Parker ou como o desafortunado Homem-Aranha.

\section{Outras seqüências}

As $\mathrm{HQ}$ que seguiram essa primeira série mantiveram sempre um roteiro parecido, tendo o herói confrontado não somente seus inimigos, mas também o povo, a mídia, e seus próprios conflitos interiores, entre eles seu profundo sentimento de culpa pela morte do tio e pela situação financeira da tia. A cada nova $\mathrm{HQ}$ criada, novos inimigos do Homem-Aranha foram aparecendo: Dr. Octopus (The Amazing Spiderman, n.3, julho de 1963), Homem-Areia (The Amazing Spiderman, n.4, setembro de 1963), Dr. Doom (The Amazing Spiderman, n.5, outubro de 1963), entre outros.

As revistas lançadas nos últimos anos no Brasil pela Panini Comics têm novo formato, desenhos muito mais complexos e ágeis, que extrapolam a moldura dos quadrinhos e mostram cenas com diferentes tomadas, sob diversos ângulos. Os roteiros são mais elaborados, mesclando personagens antigas como o Diabo Verde, Dr. Octopus e o Homem-Areia e monstros alienígenas criados mais recentemente. O cenário muitas vezes foge da Nova York que conhecemos, dando lugar a ambientes ermos e inóspitos. Os temas são muitas vezes mais voltados ao público adulto jovem do que propriamente ao infanto-juvenil ${ }^{316}$. Os fascículos mensais trazem HQ incompletas (divididas em quatro ou cinco partes), o que "obriga" de certa forma os leitores a comprarem o número seguinte para terem acesso à continuação da história.

\footnotetext{
${ }^{316}$ Na revista de Dezembro/ 2005, na história "Reviravolta", parte 2/5, por exemplo, há uma grande seqüência de quadrinhos com uma clara tentativa de estupro entre monstros alienígenas (pp. 54-72).
} 
Devido à impossibilidade de abordarmos o enredo de forma integral devido à sua extensão, para o estudo do percurso desta personagem que faremos a seguir, restringiremos nossa análise à $\mathrm{HQ}$ original de $\mathrm{O}$ HomemAranha, além de alguns episódios avulsos de outras revistas cuja problemática seja pertinente ao escopo do nosso trabalho.

\subsubsection{Desdobramentos}

Há muito o Homem-Aranha transpôs as molduras traçadas pelos quadrinhos em 1962 para ganhar outras mídias: em 1967, surgiu a primeira série de desenhos animados, realizada nos estúdios Hanna-Barbera. Em 1978, foi ao ar o primeiro seriado para a televisão, retomado em 1985.

Além dos quadrinhos, animações, filmes, seriados e games, uma série de produtos relacionados ao super-herói começou a fazer parte da vida de crianças e jovens: são brinquedos, roupas, acessórios, objetos de decoração, material escolar, fantasias, entre outros.

Recentemente, a HQ ganhou novas adaptações para o cinema. Os longas-metragens Homem-Aranha - o filme (2002) e Homem-Aranha 2 (2004) bateram vários recordes de bilheteria em todo o mundo, na transposição do herói dos quadrinhos para a magia e os efeitos da grande tela, contando com todos os recursos da computação gráfica (Figura 6). 

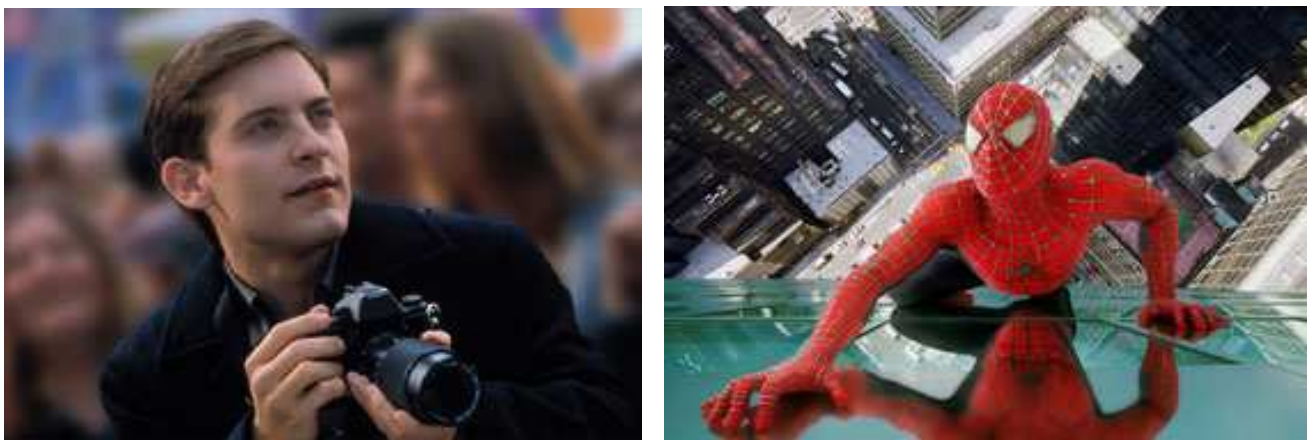

Figura 6 - $\mathrm{O}$ ator Tobey Maguire como o fotógrafo Peter Parker (à esquerda) e mostrando a agilidade do super-herói, como Homem-Aranha (à direita) - Cenas do filme Spiderman, 2002

Embora bastante modificado com relação ao enredo da $\mathrm{HQ}$ original, o primeiro filme traz na essência o drama do adolescente órfão e seu tortuoso caminho em busca de si mesmo. Frases escritas por Stan Lee há mais de quarenta anos - como, por exemplo, "Grande poder traz grande responsabilidade" - ganham novo valor e novo significado na voz do ator Tobey Maguire, protagonista e narrador do filme.

O segundo filme exacerba os conflitos interiores do herói, a ponto de ele sentir-se impelido a abandonar seu destino de super-herói para primeiramente se reencontrar como Peter Parker. Porém a tentativa não dá certo e ele é obrigado a voltar a ser Homem-Aranha para proteger e salvar as pessoas a quem ele ama (Figura 7).
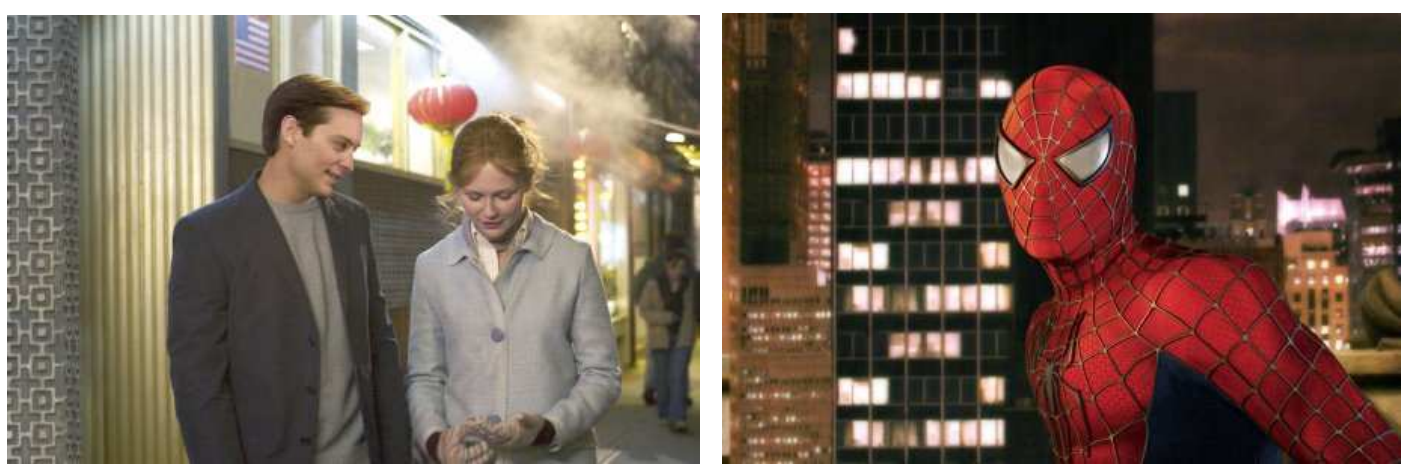

Figura 7 - Peter Parker dividido entre o amor de Mary Jane (à esquerda) e o compromisso como Homem-Aranha (à direita) - Cenas do filme Spiderman 2, 2004 
Devido ao grande sucesso de público alcançado pelos dois filmes, o terceiro Homem-Aranha já está em fase de produção, para ser lançado em meados de $2007^{317}$.

317 O site oficial responsável pela divulgação dos filmes (http://spiderman.sonypictures.com) traz inclusive a contagem regressiva para a estréia do filme, mesmo ainda estando a mais de um ano de sua estréia (programada para o dia 4 de maio de 2007). 


\subsubsection{O órfão no cinema}

Assim como a literatura e os quadrinhos, também o cinema tem sido suporte para vários enredos cujos protagonistas são órfãos. Harry Potter e Homem-Aranha são apenas dois exemplos recentes entre inúmeras adaptações de sucesso que abordam essa temática. Iniciaremos, porém, este breve histórico analisando primeiramente algumas personagens do repertório das animações ${ }^{318}$.

Entre roteiros originais e recriações de contos de fadas ou de clássicos infantis que ganharam som e movimento em animações para 0 cinema há, curiosamente, um significativo número de órfãos como protagonistas. A relação dos longas-metragens com essa característica vai desde a primeira animação da Disney (Branca de Neve e os sete anões) ${ }^{319}$ até o recente Galinho Chicken Little (2005), incluindo personagens já conhecidas da literatura, como Pinóquio e Cinderela, e outras que acabaram ganhando destaque nas telas de cinema, como Bambi e Simba.

Em alguns casos, como Branca de Neve (1937), Cinderela (1950), A Bela e a Fera (1991) ou mesmo nos recentes Lilo \& Stitch (2002) e O Galinho Chicken Little (2005), as personagens centrais são sabidamente órfãs desde o princípio do enredo, sendo a orfandade um fato consumado.

Porém em outros, a morte da mãe ou do pai (ou de ambos) ocorre com o filme já em andamento, configurando momentos de muita "tensão" nessas tramas. É o caso, por exemplo, de Bambi (1943), O rei leão (1994),

318 Serão chamadas "animações" as produções cinematográficas elaboradas a partir de imagens em movimento provenientes de desenhos, bonecos ou quaisquer objetos filmados ou desenhados quadro a quadro.

${ }^{319}$ Branca de Neve e os sete anões foi determinante na história da animação do cinema, sendo o primeiro longa-metragem animado produzido na América. 
Tarzan (1999) e Procurando Nemo (2003), sobre os quais nos deteremos um pouco mais a seguir.

Embora não tenha sido o cinema sua fonte original, a personagem Bambi ficou conhecida no mundo todo devido à adaptação de Walt Disney realizada em 1943 para o conto do australiano Felix Salten (1869-1945), publicado vinte anos antes em Viena com o título Bambi, ein Leben im Walde (Bambi, uma vida na floresta, 1923).

O enredo narra um ciclo completo na vida de um veado, desde o seu nascimento até o nascimento de seu filho, enquanto o cenário vai-se modificando de acordo com as estações do ano.

Logo no início do filme, Bambi é apresentado a outros animais da floresta por sua mãe. Aos poucos o filhote aprende a equilibrar-se e alimentarse, e é constantemente alertado pela mãe sobre o perigo dos caçadores, que estão sempre rondando a floresta. Em uma das cenas mais impactantes da animação, o pequeno veado e sua mãe fogem dos tiros em meio à neve. Quando Bambi percebe que está sozinho e chama pela mãe, embora o filme não mostre de forma explícita, não é difícil deduzir o que lhe havia acontecido (Figura 8).

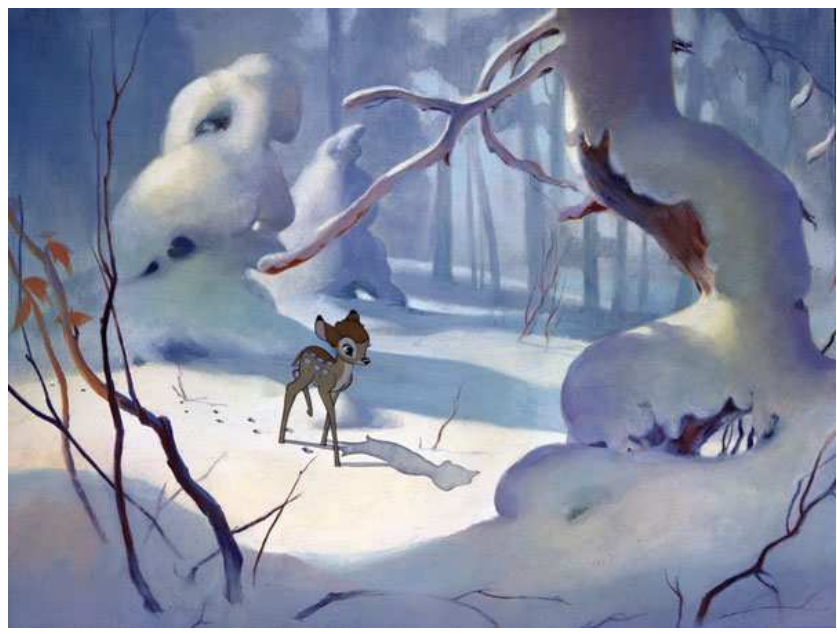

Figura 8 - Órfão, Bambi deve aprender a sobreviver sozinho. Cena do filme Bambi, 1943. 
A partir desse momento, o pequeno veado tem que aprender a sobreviver sem sua guia e protetora, contando, para isso, com a ajuda de amigos da floresta, entre eles o coelho Tambor e o gambá Flor. O tempo passa, os animais amadurecem, encontram seus pares e, com a chegada de uma nova primavera, o ciclo da vida se reinicia, quando Bambi constitui sua própria família.

Embora sozinho o órfão tenha aprendido a tirar proveito das dificuldades para relacionar-se socialmente, fazendo amigos e encontrando uma fêmea, a morte de sua mãe não deixa de ser uma experiência angustiante tanto para ele, como para os espectadores do filme.

O escritor Luís Fernando Veríssimo, por exemplo, em recente crônica publicada em $O$ Estado de $S$. Paulo, faz menção à morte da mãe do Bambi como um "trauma" difícil de ser superado:

Num recente encontro de escritores na França, um americano (...), Jerome Charyn, revelou que a grande tragédia da vida dele, o que marcou sua personalidade e provavelmente sua literatura para sempre, foi a morte da mãe do Bambi. Muitos riram, mas eu entendi imediatamente o que ele queria dizer. Temos mais ou menos a mesma idade. Somos da geração que nunca se recuperou da morte da mãe do Bambi. Todos os nossos parâmetros de maldade, injustiça e perda vêm desta experiência. A descoberta de que mãe também morre é um trauma comum a todas as espécies, desde o primeiro bicho, mas só quem assistiu à morte da mãe do Bambi no cinema com uma idade impressionável teve uma evidência gráfica, arrasadora, deste fato. (...) Culpa do Walt Disney, que ainda nos traria a imagem do elefante Dumbo sendo embalado pela tromba da sua mãe presa numa jaula de circo, para acabar de vez com todas as nossas ilusões sobre a vida ${ }^{320}$.

${ }^{320}$ VERISSIMO, L. F. "A morte da mãe do Bambi" in O ESTADO DE S. PAULO, Caderno 2, 15/12/2005, p. D14. 
Outra animação que aborda de forma enfática a questão da morte de um dos progenitores de modo a intensificar a orfandade do protagonista é $O$ Rei Leão (1994).

Diferentemente de Bambi e de outras dezenas de recriações que o antecederam, ao que tudo indica, O Rei Leão foi o primeiro longa-metragem da Disney baseado em um roteiro original para cinema, sem ter sido adaptado de contos clássicos ou histórias conhecidas ${ }^{321}$. Talvez por isso mesmo alguns críticos se refiram a esse filme como o "Bambi africano", pelo fato de o tema abordar um animal órfão e a África ser o cenário escolhido para a nova produção.

Porém é possível notar mais diferenças que semelhanças entre os enredos, a primeira delas sobre a própria questão da orfandade: enquanto em Bambi a relação mais forte do filho era com a mãe, e por isso sua perda lhe é grande e dolorosa, em $O$ Rei Leão o pequeno Simba, herdeiro do trono, procura espelhar-se no pai, o poderoso Mufasa, rei dos animais.

Vítima da inveja e da ganância do seu tio Scar e da sua própria inexperiência e ingenuidade, Simba é atraído para uma armadilha que visava acabar com pai e filho de uma só vez. Em um ato de coragem, Mufasa consegue salvar seu filho, mas não escapa da ira do irmão, que o joga do alto de um penhasco. Vendo seu plano em parte fracassado, Scar convence o pequeno Simba a fugir, atribuindo-Ihe a culpa pela queda do rei. Acreditando ter sido ele mesmo o responsável pela morte do pai, Simba foge e somente depois de muito tempo voltaria para reocupar seu lugar.

${ }^{321}$ Existe a hipótese de que o filme teria sido inspirado na animação japonesa Kimba, the White Lion, criação de Osamu Tezuka, porém não há qualquer referência a essa obra nos originais da Disney. 
O ciclo da vida presente de maneira implícita na narrativa de Bambi é retomado nesta produção da Disney de forma mais categórica e intencional, uma vez que, além de o filme também começar e terminar com o nascimento de um filhote, a música-tema do longa-metragem ("Ciclo da vida") ${ }^{322}$ - que acompanha esses dois momentos - torna explícito o tema da renovação:

É um ciclo sem fim

Que nos guiará

A dor e a emoção

Pela fé e o amor

Até encontrar o nosso caminho

Neste ciclo, neste ciclo sem fim

Alguns diálogos esporádicos que ocorrem durante o filme também abordam o tema, levantando o fato de a própria cadeia alimentar ser um "ciclo sem fim". Para o protagonista Simba, esse ciclo se completa com o nascimento de seu filho. Assim como em Bambi, a orfandade do pequeno leão só é compensada quando ele consegue constituir sua própria família, deixando de ser filho para tornar-se pai (Figura 9).
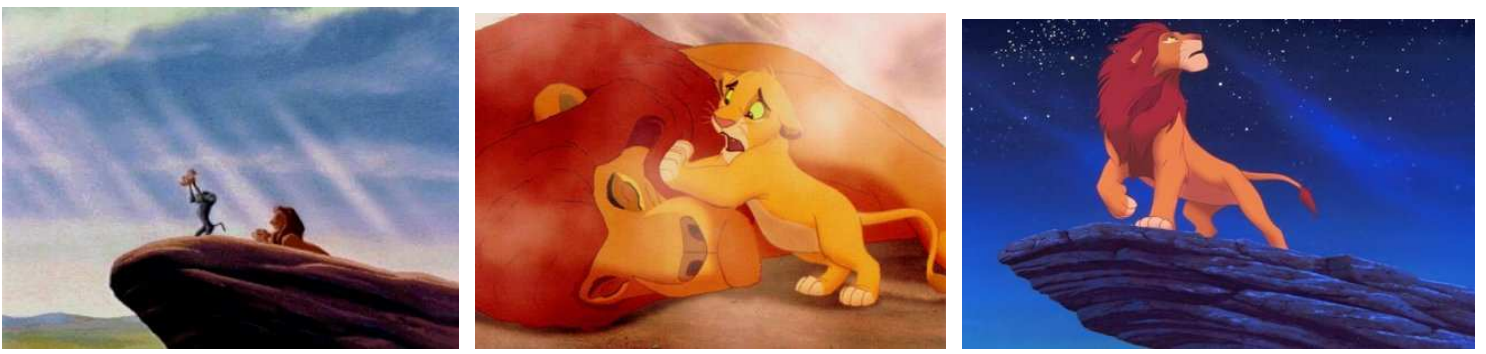

Figura 9 - Simba é apresentado ao povo como herdeiro do rei Mufasa (à esquerda); a morte de Mufasa, testemunhada pelo filho (ao centro); Simba finalmente ocupa o lugar do pai (à direita). Três cenas do filme $O$ rei leão, 1994.

322 "Circle of life" (música de Elton John, letra de Tim Rice) faz parte da trilha sonora original para o filme. Letra original em inglês: "It's the circle of life / And it moves us all / Through despair and hope / Through faith and love / Till we find our place / On the path unwinding / In the circle / The circle of life". 
Tanto em Bambi como em $O$ Rei Leão, a morte de um dos progenitores traz grande sofrimento para os protagonistas. No entanto, não é o que se verifica em outro clássico da Disney - Tarzan (1999) -, em que há a morte de pai e mãe da personagem. A recente animação realizada para a conhecida série de Edgar Rice Burroughs mostra logo nos primeiros minutos do filme o pequeno bebê órfão sendo encontrado por uma família de gorilas após o ataque de um leopardo ${ }^{323}$ ao acampamento onde ele vivia com seus pais. Único sobrevivente, Tarzan não chega a sofrer com a perda dos pais, uma vez que ele é muito pequeno e logo é adotado pela gorila Kala.

Também em Procurando Nemo (2003), a morte prematura da mãe não é motivo de sofrimento para o filhote de peixe-palhaço do título, uma vez que ele ainda nem havia saído de seu ovo quando o fato aconteceu ${ }^{324}$. No entanto, o que realmente incomoda o protagonista durante o filme é a perda temporária do pai, que ocorre quando Nemo é capturado por um mergulhador e passa a viver em um aquário juntamente com outras espécies marinhas.

O tema da separação temporária dos pais não é novidade entre as animações para o cinema, uma vez que já havia sido explorado em diversas outras adaptações, como Dumbo $(1940)^{325}$, Pinóquio (1940) ${ }^{326}$, A era do gelo

${ }^{323}$ No original de Edgar Rice Burroughs é um gorila quem ataca e mata os pais de Tarzan.

${ }^{324}$ Quando Nemo era ainda um embrião em seu ovo, o coral onde a família vivia sofre o ataque de um peixe maior, do qual restam apenas Marlin, o pai, e um único ovo do qual nasce Nemo. O tempo passa e pai e filho vivem felizes, até o dia em que Nemo é capturado por um mergulhador. Vencendo os próprios medos, Marlin sai em busca do filho perdido, vivendo as aventuras de um enredo paralelo. O reencontro entre pai e filho se dará apenas no final do filme.

325 Para proteger seu filhote Dumbo das gozações que ele sofria por causa das grandes orelhas, a elefanta Jumbo joga água nas pessoas e é considerada "louca" pelos donos do circo. Dumbo tem então que aprender a viver sozinho, sem o carinho e o cuidado da mãe. Somente no final do filme dá-se o reencontro, quando Dumbo aprende a voar e passa a ser a estrela do circo.

${ }^{326}$ A conhecida história do boneco de madeira mentiroso ganhou uma adaptação da Disney que é por muitas pessoas mais conhecida do que o próprio original de Collodi. Embora nunca tenha tido "mãe", Pinóquio passa quase todo o enredo do filme afastado de seu "pai" Gepetto, a quem desobedece. Depois de muito errar em seu caminho, Pinóquio vai à 
$(2002)^{327}$ ou Robôs $(2005)^{328}$, apenas para citar algumas. Em todos esses filmes o herói tem que aprender a se defender sozinho enquanto os pais - por motivos diversos - ficam temporariamente afastados.

Um outro aspecto da orfandade encontrado em animações é o da criança enjeitada criada por outra família, que não a sua própria. É o caso, por exemplo, das adaptações para o cinema das histórias de Hércules (Hércules, Disney, 1997) e Moisés (O príncipe do Egito, Dreamworks, 1998). Em ambos os casos, o herói, ainda bebê, é abandonado à própria sorte e encontrado por uma família que o adota, e apenas na adolescência vem a conhecer a verdadeira história de sua vida.

Porém o tema da orfandade em longas-metragens originais ou recriados a partir de outros meios não é exclusividade das animações. Muitas adaptações de contos maravilhosos, clássicos infantis, romances consagrados e $\mathrm{HQ}$, ou ainda argumentos criados especialmente para o cinema, que trazem órfãos como personagens, têm sido registrados desde os tempos em que o cinema era desprovido de cores ou de efeitos sonoros e visuais.

Um dos roteiros originais mais antigos e conhecidos em que a criança abandonada ganha destaque, chegando a "roubar" algumas cenas do protagonista, é o clássico O Garoto (The Kid, 1921), com roteiro, direção, produção e música de Charles Chaplin (1889-1977) - que também atua no filme (Figura 10a).

procura do pai, encontrando-o dentro de uma baleia. Salvando Gepeto da morte, finalmente Pinóquio vira um "menino de verdade" e pode usufruir novamente de um lar ao lado de seu pai.

${ }^{327}$ Nesta animação da Fox em parceria com a Blue Sky, animais pré-históricos encontram uma criança perdida após um ataque ao acampamento dos pais e pretendem devolvê-la à família. O reencontro acontece somente no final do filme.

${ }^{328}$ Também dos estúdios Fox/ Blue Sky, essa recente animação conta as aventuras de um robô inventor que decide partir do lugar onde vive com os pais para conhecer seu maior 
No enredo, um bebê abandonado pela mãe no banco de trás de um carro é encontrado por um vagabundo (Charles Chaplin), que começa a viver um verdadeiro dilema entre abandoná-lo à própria sorte ou adotá-lo definitivamente.

Já uma das primeiras e mais recorrentes adaptações de uma obra originária de outro meio chegava às telas cerca de três anos antes do lançamento de $O$ Garoto: Tarzan dos macacos, já citada sob o ponto de vista literário, dos quadrinhos e da animação, cuja primeira versão cinematográfica estreou em 1918, com Elmo Lincoln ${ }^{329}$ no papel principal e direção de Scott Sidney (Figura 10b).
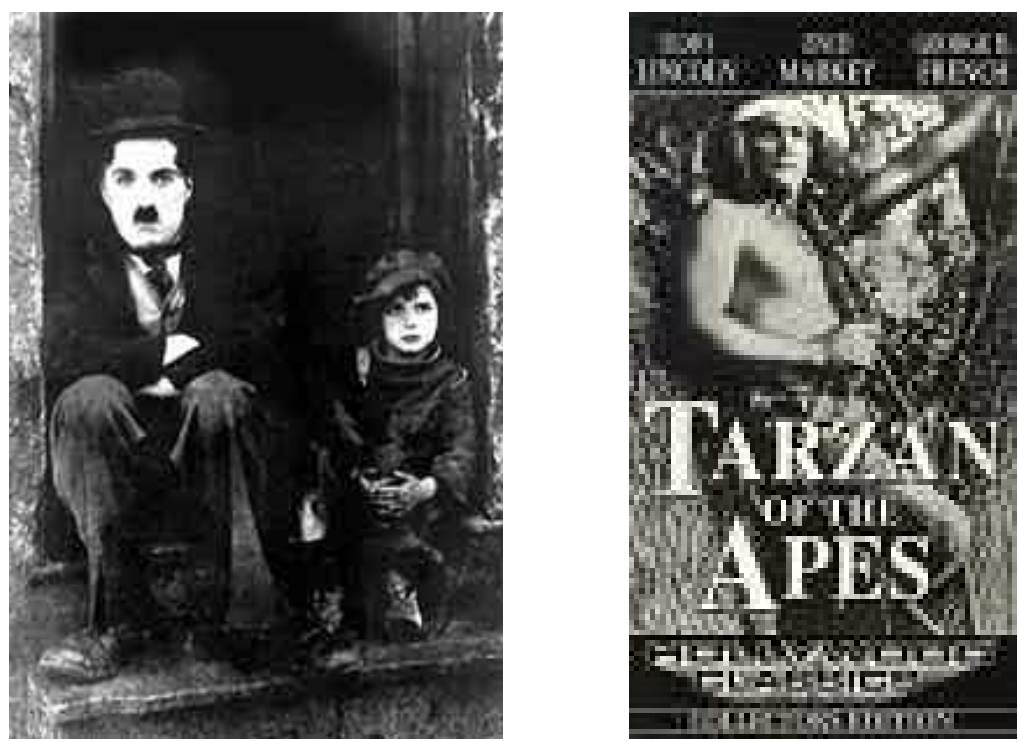

Figura 10 - a) À esquerda, fotografia de divulgação do filme $O$ garoto, com Charles Chaplin no papel de "vagabundo" e Jackie Coogan no papel de "garoto" (1921); b) À direita, reprodução do pôster da primeira adaptação de Tarzan of the Apes, clássico de Edgar Rice Burroughs, com Elmo Lincoln no papel principal (1918).

ídolo e tentar uma vida melhor. Temporariamente órfão, somente nas cenas finais do filme o robô volta a encontrar seus pais.

${ }^{329}$ Depois dele outros dezesseis atores protagonizaram o papel, entre eles o nadador olímpico Johnny Weissmuller, tendo sido uma das personagens mais populares do cinema de todos os tempos. O último Tarzan foi interpretado pelo ator Christopher Lambert em 1983 (www.guiadoscuriosos.com.br acessado em 20/12/2005). 
Inúmeros outros romances e novelas tiveram suas várias transposições para as telas de cinema, e muitos atores incorporaram na pele protagonistas órfãos de obras clássicas, como Oliver Twist, David Copperfield, Jane Eyre, A princesinha, entre outros (Figura 11) ${ }^{330}$.
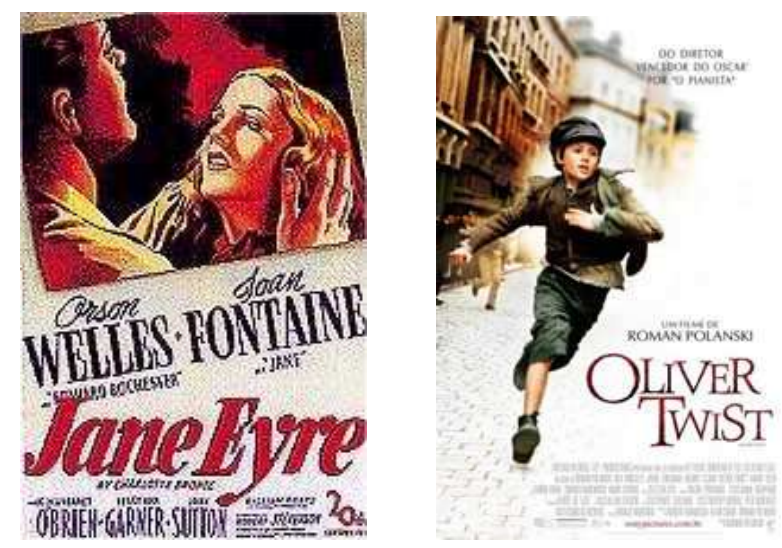

Figura 11 - Reprodução do pôster de uma das mais aclamadas adaptações de Jane Eyre (1944), com Orson Welles, e da mais nova transposição para o clássico de Charles Dickens (Oliver Twist, 2005), do diretor Roman Polanski.

Um exemplo mais recente de uma adaptação de sucesso é o filme Regras da Vida (The cider house rules, 1999) ${ }^{331}$, baseado no romance homônimo de Jonh Irving ( $\left.{ }^{*} 1942\right)$, que conta a história do órfão Homer Wells desde o seu nascimento e sua criação em um orfanato até sua partida para conhecer melhor o mundo e suas "regras".

Enredos menos realistas também ganharam adaptações de sucesso quando transportados para o cinema, como por exemplo Inteligência Artificial (A.I. Artificial Inteligence, 2001) ${ }^{332}$, o último filme de Stanley Kubrick, realizado em pareceria com Steven Spielberg e baseado no conto de Brian Aldiss (*1925), Superbrinquedos duram o verão todo (Supertoys Last All Summer

${ }^{330}$ Todas as obras aqui citadas foram analisadas nos capítulos precedentes.

${ }^{331}$ O livro foi publicado pela primeira vez em 1985. O próprio John Irving adaptou-o para o cinema, recebendo o Oscar em 2000 por roteiro adaptado.

332 Já citado no segundo capítulo desta dissertação, quando abordados os atalhos no caminho do herói órfão, mais particularmente a questão das madrinhas. 
Long and Other Stories of Future Time, 1969), cujo argumento se desenvolve entre a adoção e o abandono de uma criança-robô ${ }^{333}$.

Os recentes destaques da literatura contemporânea que apresentam órfãos como protagonistas também têm inspirado versões cinematográficas quase imediatas, como o já citado Harry Potter - que conta até agora com quatro longas-metragens ${ }^{334}$, estando o quinto já em produção - e a primeira adaptação das Desventuras em série ( $A$ series of unfortunated events, 2004), que também promete continuações.

Outro gênero que tem sido freqüentemente transposto para o cinema é o das $\mathrm{HQ}$ protagonizadas por heróis órfãos, que na última década contou com várias adaptações novas ${ }^{335}$.

Porém para representar o cinema na análise comparativa que faremos a seguir, elegemos o herói Luke Skywalker, protagonista da primeira trilogia de Guerra nas Estrelas (Star Wars, 1977/ 1980/ 1983) - criação original para o cinema do roteirista, produtor e diretor George Lucas - e cujo perfil equivale ao dos heróis da literatura e dos quadrinhos previamente selecionados.

${ }^{333}$ No filme, a história é ambientada no ano 2141. O menino-robô David é adotado por um casal que vivia o drama de ter um filho natural desenganado. A mãe reluta em aceitar o robô, e, com a recuperação do filho legítimo, cresce cada vez mais sua rejeição por David. Quando percebe que seu verdadeiro filho poderia correr perigo ao lado do robô, a mãe abandona David numa floresta, onde ele terá que aprender com outros seres desprezados a sobreviver num mundo selvagem. Muitos críticos consideraram esse filme como uma versão moderna de Pinóquio, principalmente por causa da referência à Fada Azul que o órfão faz durante o enredo.

${ }^{334}$ Harry Potter e a pedra filosofal, 2001; Harry Potter e a câmara secreta, 2002; Harry Potter e o prisioneiro de Azkaban, 2004 e Harry Potter e o cálice de fogo, 2005.

335 Homem-Aranha (2002); Hulk (2003); Demolidor (2003); Homem-Aranha 2 (2004); Batman Begins (2005). 


\subsubsection{Luke Skywalker e o cinema - o suporte original}

Luke é uma personagem comum que atinge a estatura de herói; seu inimigo supremo é um destruidor que almeja devorar tudo, e sua maldade está direcionada pessoal e especificamente para acabar com o próprio herói. No final, o herói deve enfrentar esse monstro sozinho, em um confronto fora do controle das forças organizadas do bem.

(Mary Henderson) $)^{336}$

O filme original da primeira trilogia de Guerra nas Estrelas (Star Wars, 1977) - ou Episódio IV: Uma nova Esperança, como depois foi chamado apresenta-nos a personagem Luke Skywalker, um jovem órfão criado pelos tios no longínquo e inóspito planeta Tatooine, distante de todos os acontecimentos importantes da "Galáxia". As seqüências, Episódios V e VI, mostram o caminhar desse herói solitário e seus confrontos com as terríveis forças do mal.

Somente vinte e dois anos depois da primeira aparição de Luke nas telas teríamos acesso à história de seu pai, Anakin Skywalker, quando a segunda trilogia de Guerra nas Estrelas era lançada (Episódio I - $A$ ameaça fantasma, 1998).

A primeira imagem de Guerra nas Estrelas que se repete a cada novo episódio fornece-nos uma chave de leitura para toda a saga: "Há muito tempo, em uma galáxia muito, muito distante...”337. A frase solta sobre o fundo negro, precedendo qualquer outra imagem ou som do filme, remete o espectador a um adormecido acesso ao imaginário, a um familiar "Era uma vez"...

\footnotetext{
${ }^{336}$ HENDERSON, M. Star Wars - The magic of myth. Nova York, Bantam Books, 1997, p. 198. Texto original em inglês: "Luke is an ordinary character who grows to heroic stature; the supreme enemy is a destroyer who would devour all, and his malice is directed personally and specifically at the hero himself. Ultimately, the hero must face this monster alone, in a confrontation that takes place outside the organized forces for good".

${ }^{337}$ Original em inglês: "A long time ago in a galaxy far, far away...."
} 
Assim como J. K. Rowling, o produtor, diretor e cineasta George Lucas não foi nada modesto ao imaginar e planejar a saga que iria mudar a história do cinema moderno. O primeiro Guerra nas Estrelas foi pioneiro na arte de efeitos especiais jamais realizados antes, e os filmes que deram seqüência à primeira trilogia não ficaram atrás. Todo o trabalho de bastidores realizado por George Lucas para tornar possível a produção e execução de seus filmes pode ser visto em O Império de Sonhos - A história da Trilogia Star Wars, ${ }^{338}$ um documentário de duas horas e meia de duração que relata detalhes pormenorizados das filmagens, produção e montagem dos filmes, bem como as dificuldades encontradas e o valor inestimável da obra para o panorama do cinema mundial.

Embora tenha feito diversas alterações em seu roteiro original - e mesmo antes de lançar Guerra nas Estrelas, em 1977 -, George Lucas pretendia realizar seguimento à série. Tanto que, ao rebatizar o primeiro filme como Episódio IV - Uma nova esperança, abriu precedentes para dar continuidade à trama tanto para frente, com os episódios $\mathrm{V}$ e VI, quanto para trás, com os Episódios I, II e III. Ao terminar os Episódios V e VI, respectivamente em 1980 e 1983, porém, muitos acreditavam que o ciclo de Guerra nas Estrelas estava concluído. No entanto, dezesseis anos depois do lançamento do último longa-metragem ( $O$ retorno de Jedi), chegava às telas de cinema de todo o mundo Episódio I - A ameaça fantasma (1999), seguido por Episódio II - Ataque dos Clones (2002) e Episódio III - A vingança dos Sith (2005). Completava-se, então, uma das sagas cinematográficas de maior sucesso de todos os tempos.

${ }^{338}$ Império dos sonhos: a história da Trilogia Star Wars. Direção de Edith Becker e Kevin Burns. Los Angeles, Prometheus Entertainment/ Fox Television Studios /Lucas Film Ltda. 


\subsubsection{A obra}

Guerra nas estrelas foi muitas vezes definida como "um conto de fadas espacial", talvez porque traga em seu âmago a eterna luta entre o bem e o mal, representados respectivamente pelos Cavaleiros Jedi e os vilões Sith ${ }^{339}$.

Ed Singer, roteirista do documentário O Império de Sonhos, afirma que "com esse conto de fadas galáctico, Lucas esperava reinventar um gênero clássico". Cita como um dos mentores da obra de Lucas o erudito e educador Joseph Campbell, a quem o cineasta teria feito várias consultas e pedido conselhos.

Led Brandy, historiador cultural e professor de História da Universidade do Sul da Califórnia, acredita que Lucas baseou-se nas idéias de Campbell sobretudo no interesse do estudioso sobre as ligações entre mitos de diferentes proveniências, no qual ele procura estabelecer os "fios comuns que costuram juntas essas culturas distintas" ${ }^{\text {340 }}$. O próprio George Lucas dá o seguinte depoimento:

Pesquisei tentando condensar tudo em temas que fossem universais. Devo muito do sucesso aos fundamentos psicológicos que existem há milhares de anos, mas ainda causam a mesma reação nas pessoas quando elas ouvem estórias. (...) É a história tradicional e ritualística do amadurecimento ${ }^{341}$.

Ed Singer conclui seu argumento sobre o sucesso de Guerra nas Estrelas da seguinte maneira:

Distribuição: Star Wars Trilogia - Disco Bônus, DVD/Vídeo, 2004. Son., color., 180 min.

339 Jedi (pronúncia: "Jedai") é o termo usado para Cavaleiros que defendiam a República na Galáxia na série Star Wars. Sith é a denominação utilizada para designar aqueles que dominam o "lado negro da força", do qual fazem parte sempre um mestre e seu aprendiz (na trilogia original - Episódios IV a VI - os vilões são representados pelo Imperador Palpatine (mestre) e Darth Vader (seu aprendiz).

340 Op. cit. Nota 338.

${ }^{341}$ Idem, ibidem. 
Não era uma história de culturas ou nacionalidades; não era uma história de geografia. Era uma história da humanidade fugindo de seu ambiente para uma vida que todos esperam que aconteça e que George Lucas conseguiu ilustrar para nós. Foi isso que deu este sucesso mundial ao filme ${ }^{342}$.

\subsubsection{O enredo}

Dos três enredos analisados neste capítulo da dissertação, sem dúvida o de Guerra nas Estrelas é o mais complexo de todos. A começar pelo fato de George Lucas ter invertido a ordem cronológica dos acontecimentos, iniciando seu projeto pela história do jovem Luke Skywalker, na primeira trilogia (Episódios IV, V e VI), para depois contar a história do pai, Anakin Skywalker, na segunda trilogia (Episódios I, II e III). Além disso, para compor sua saga, Lucas criou uma profusão de estrelas e planetas, além de dezenas de espécies de alienígenas. A linha do tempo de seu enredo central percorre 40 anos, entre a descoberta do menino Anakin (Episódio I) e a morte do Imperador (Episódio VI). Porém como o que nos interessa nesta dissertação é a história do filho - e não a do pai -, nossa abordagem será direcionada aos três episódios finais da saga.

\section{Episódio IV}

Luke Skywalker é um jovem órfão criado pelos tios fazendeiros que não o maltratam como ocorre em Harry Potter, mas exigem que o rapaz trabalhe na colheita e "prendem-no" de certa forma em um lugar distante dos principais acontecimentos da Galáxia. O sonho de Luke é sair do Planeta Tatooine para cursar a Academia e tornar-se um piloto estelar; no entanto, o jovem vê sua vida dar uma reviravolta quando seus tios são assassinados por

${ }^{342}$ Idem, ibidem. 
guardas do Império e ele descobre, por meio de um velho ermitão - o mestre Jedi exilado Obi-Wan Kenobi - alguns fatos que lhe foram omitidos sobre a "verdadeira" história de seu pai ${ }^{343}$. Luke parte então com Obi-Wan para uma importante missão: resgatar a Princesa Léia. Nos confrontos que se seguem, Obi-Wan é morto pelo vilão Darth Vader, fiel discípulo do Imperador e pertencente ao "Lado Negro da Força". Com a ajuda do amigo Han Solo, Luke consegue fugir e destruir a mais poderosa arma do Império: a Estrela da Morte.

\section{Episódio V}

Luke Skywalker agora faz parte da Aliança Rebelde, que luta contra as forças do Império. No início do Episódio, Luke ouve a voz de Obi-Wan, que o aconselha a procurar Yoda, o único Jedi que restara na Galáxia, para que o velho mestre possa treiná-lo. Luke segue o conselho de Obi-Wan e inicia seu treinamento, mas pressentindo o perigo por que passam Han Solo e Léia, abandona Yoda para poder ajudá-los.

A captura de Han e Léia era na verdade uma armadilha para atrair Luke. Na batalha final com Darth Vader, o jovem Jedi descobre que o vilão é na verdade seu pai, que quando jovem cedera às tentações do Lado Negro da Força. Vader convida Luke a juntar-se a ele e o herói, mesmo ferido, consegue escapar com a ajuda de Léia. No entanto, seu amigo, Han Solo, é feito prisioneiro.

\footnotetext{
${ }^{343} \mathrm{Na}$ verdade o velho Obi-Wan omite de Luke a principal verdade sobre seu pai: o fato de ele ter-se transformado em seu principal inimigo, Darth Vader. Esse fato somente será revelado ao herói no Episódio V, O Império contra-ataca.
} 


\section{Episódio VI}

Mesmo sem ter completado seu treinamento, Luke Skywalker assume a condição de Cavaleiro Jedi e volta a Tatooine, o planeta onde foi criado, para ajudar o amigo Han Solo. Usando os poderes da mente que aprendera com Yoda e ajudado por amigos, Luke consegue resgatar Solo e os rebeldes partem para uma nova missão: destruir a segunda Estrela da Morte, recémconstruída pelo Império. Antes de assumir seu papel no combate, Luke volta a encontrar-se com Yoda, que confirma a identidade de Darth Vader como Anakin Skywalker, seu pai, e acrescenta o fato de Léia ser sua irmã gêmea. Doente e sem forças para treinar seu aprendiz, Yoda afirma que Luke só será realmente um Cavaleiro Jedi quando derrotar Vader. Com a morte de Yoda, Luke reúne-se novamente aos rebeldes e todos partem para o confronto final. Enquanto seus amigos unem esforços para destruir a arma mortal do Império, Luke entrega-se a Vader e planeja convertê-lo novamente para o "lado bom" da Força. Mais uma vez trava-se a batalha entre pai e filho mas, desta vez, é Luke quem consegue vencer. Após a derrota de seu mais poderoso aprendiz, o Imperador tenta converter e em seguida matar o jovem herói, mas Darth Vader o impede, atirando o poderoso Sith em um precipício, redimindo-se com o filho. Enquanto isso a Aliança Rebelde destrói a nova Estrela da Morte, e a saga termina com a união de Han Solo e Léia, e muita festa em todos os planetas da Galáxia. 


\subsubsection{Desdobramentos}

Muito antes de a segunda trilogia ter sido sequer iniciada, o universo de Guerra nas Estrelas há muito já se havia expandido em diferentes direções: o primeiro suporte a ser explorado pela indústria que mantinha os direitos do filme foi a literatura, traçando-se um caminho inverso do que é o mais usual (da literatura para o cinema). Porém a difusão da saga não se esgotou na simples transposição dos roteiros dos três filmes para o âmbito literário, mas foram criadas "continuações" inéditas para o enredo, entre elas Heir to the Empire (1992), Dark Force Rising e The Last Command (1993) ${ }^{344}$ de autoria de Timothy Zahn $\left({ }^{*} 1951\right)^{345}$ com a supervisão de George Lucas, que ficaram conhecidas como "a trilogia de Trawn" ${ }^{446}$ (Figura 12). Nessa continuação, novas personagens foram acrescentadas, entre elas a futura esposa de Luke (Mara Jade) e os filhos de Han Solo e Léia (Jacen e Jayna), além de novos cavaleiros Jedi e novas forças do mal, dando-nos a idéia de que uma história nunca tem um verdadeiro fim.
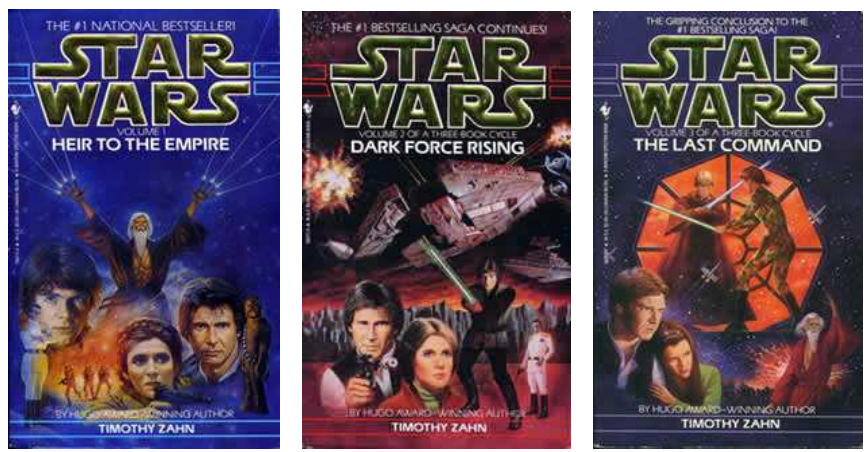

Figura 12 - Livros que compõem a “Trilogia de Trawn” (1992-1993).

${ }^{344}$ No Brasil, os livros não alcançaram o mesmo sucesso, mas, mesmo assim, foram traduzidos. Os títulos em português para a trilogia são: Herdeiro do Império, O despertar da Força Negra e Última ordem.

345 Timothy Zahn foi o primeiro, mas não o único escritor a criar histórias baseadas na saga de Guerra nas Estrelas.

${ }^{346}$ A trilogia de Trawn, escrita por Timothy Zahn, foi um sucesso imediato, figurando em primeiro lugar na lista dos mais vendidos do New York Times. A trama começa cinco anos após a derrota do Imperador e a destruição da segunda Estrela da Morte. Ao contrário do que se esperava, o Império continuava vivo mesmo após a morte de Darth Vader. 
Depois do sucesso obtido com a continuação da saga, foi realizado um trabalho ainda mais ambicioso, que previa preencher as lacunas entre os episódios, uma vez que existia um intervalo real de tempo entre eles ${ }^{347}$. Assim nasceu, em maio de 1996, o projeto Shadows of the Empire (Sombras do Império), composto por livro ${ }^{348}, \mathrm{HQ}$, game, trilha sonora, brinquedos e cards situados entre os Episódios V e VI (Figura 13).
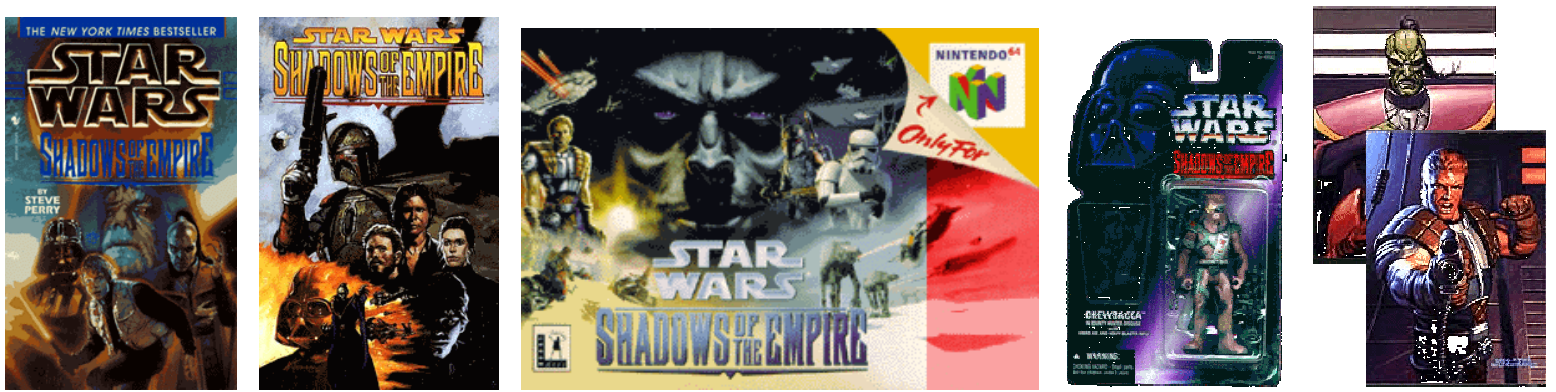

Figura 13 - Livro, HQ, game, brinquedo e cards do projeto Shadows of Empire, 1996.

Com o caminho aberto por Shadows of the Empire, os quadrinhos ganharam cada vez mais espaço dentro do "universo expandido" de Guerra nas Estrelas. Lançados em parceria com a Editora Dark Horse e com a Marvel Comics (a mesma de Homem-Aranha), primeiramente as $\mathrm{HQ}$ eram destinadas para narrar os fatos que continuariam a saga dos Jedi a partir do Episódio VI, por meio da série Dark Empire I e Il; no entanto, depois da estréia da segunda trilogia, as HQ passaram a privilegiar o episódio das "Guerras Clônicas", ocorridas cronologicamente entre os filmes $O$ ataque dos clones (2002) e $A$ vingança dos Sith (2005).

\footnotetext{
${ }^{347}$ Para situar o espectador no enredo e relembrar os episódios anteriores, a cada novo filme eram descritos em poucos parágrafos os últimos acontecimentos.

${ }^{348}$ O livro é de autoria de Steve Perry, sob a supervisão de George Lucas.
} 
Essa lacuna entre os episódios II e III tem sido também bastante utilizada por outra mídia - as animações -, que além de séries para a televisão também conta com criações inéditas para DVD.

Faz parte ainda do "universo expandido" de Guerra nas Estrelas uma infinidade de games, brinquedos, jogos, roupas, acessórios, objetos de decoração e outros adereços relacionados aos temas e às personagens marcantes da saga. 



\subsection{Percurso do órfão na atualidade: um estudo das trajetórias de Harry Potter, Peter Parker e Luke Skywalker}

Não precisamos correr sozinhos o risco da aventura, pois os heróis de todos os tempos a enfrentaram antes de nós. O labirinto é conhecido em toda a sua extensão. Temos apenas de seguir a trilha do herói... e lá, onde pensávamos estar sós, estaremos na companhia do mundo todo.

$(\text { Joseph Campbell })^{349}$

Para Joseph Campbell, "a façanha convencional do herói começa com alguém a quem foi usurpada alguma coisa, ou que sente estar faltando algo entre as experiências normais franqueadas ou permitidas aos membros da sociedade"350. Campbell afirma que "essa pessoa parte numa série de aventuras que ultrapassam o usual, quer para recuperar o que tinha sido perdido, quer para descobrir algum elixir doador da vida"351.

Do menino órfão Harry Potter foi tirada a oportunidade de viver entre os seus, quando ainda bebê teve os pais brutalmente assassinados. Levado para a casa dos perversos tios, o jovem bruxo tem uma verdadeira vida de "Gata Borralheira" até o dia em que completa onze anos, quando importantes verdades the são reveladas.

Ao adolescente órfão Peter Parker faltavam os atributos mínimos para que ele pudesse sentir-se parte de um grupo e viver a experiência da autoafirmação. O jovem foi ainda privado da convivência com seu querido tio Ben, assassinado, fato que impulsiona seu desejo de enfrentar os inimigos e lutar pela justiça.

\footnotetext{
${ }^{349}$ CAMPBELL, J. Op. cit., 1990, p. 131.

${ }^{350}$ Idem, ibidem.

${ }^{351}$ Idem, pp. 131-132.
} 
Do jovem sonhador Luke Skywalker foi escondida sua verdadeira origem, como filho do mais poderoso Cavaleiro Jedi que existira na Galáxia. Embora seu desejo fosse o de viver em uma realidade diferente da que lhe fora reservada, ele aguarda o momento de partir, mas ainda tem tempo de presenciar o extermínio dos tios e a destruição de seu lar.

Para Campbell, a aventura do herói "normalmente perfaz-se num círculo, com a partida e o retorno"352. Veremos, pois, como se estruturam esses círculos nas trajetórias de nossos três heróis órfãos ${ }^{353}$.

${ }^{352}$ Idem, p. 132.

${ }^{353}$ Harry Potter é apresentado como órfão já no primeiro capítulo de Harry Potter e a pedra filosofal, seu suporte original. Ainda nesse capítulo do livro o leitor é informado de que seus pais, Lílian e Tiago Potter - Lily e James, no original - foram assassinados, e seu lar, destruído, restando apenas o pequeno bebê de um ano. Até os onze anos de idade, vivendo com os tios, Harry acredita que seus pais tinham morrido em um acidente de carro, quando então a verdade lhe é revelada.

Peter Parker também é apresentado como órfão já nos primeiros quadrinhos da $\mathrm{HQ}$ original. Não há qualquer menção sobre seus verdadeiros pais. Ainda na primeira $\mathrm{HQ}, 0$ herói ficaria duplamente órfão, ao perder seu tio Ben, assassinado.

Luke Skywalker é criado pelos tios. Em uma conversa inicial sobre Obi-Wan Kenobi, Owen, tio de Luke, fala pela primeira vez sobre o pai do herói: "Ele (Obi-Wan) morreu na mesma época que seu pai" ("He died about the same time as your father"). Quando Luke tenta aprofundar o assunto, o tio desconversa, deixando claro que não era de seu agrado falar sobre o passado. Um pouco adiante na narrativa, o jovem vem a saber que Obi-Wan não só estava vivo, como tinha sido grande amigo e companheiro de seu pai, Anakin Skywalker. Quando Luke pergunta a Obi-Wan sobre a morte do pai, o velho mestre afirma que Darth Vader o matou. Somente no segundo Episódio da primeira trilogia Luke descobrirá - assim como o espectador - que Darth Vader é na verdade o próprio Anakin Skywalker, que passara para o "lado negro" na tentativa de evitar a morte de sua esposa, Padmé Abdalla (de quem teremos notícia apenas na segunda trilogia - Episódios I, II e III). Assim como Peter Parker, também Luke torna-se duplamente órfão logo no início da saga, quando seus tios são exterminados e seu lar, destruído. 


\subsubsection{Partida}

Ignoranti, quem portum petat, nullus suus ventus est.

Nenhum vento é favorável para aquele que não sabe onde aportar.

(Sêneca)

A partida é o primeiro passo do herói rumo à aventura. É geralmente quando ele deixa de pisar em terreno firme e seguro para lançar-se ao desconhecido. Joseph Campbell denomina esse primeiro momento, "o chamado para a aventura" ${ }^{354}$, como uma passagem por um "limiar":

O horizonte familiar da vida foi ultrapassado; os velhos conceitos, ideais e padrões emocionais já não são adequados; está próximo o momento da passagem por um limiar (...) Esse primeiro estágio da jornada mitológica - que denominamos aqui "o chamado para a aventura" - significa que o destino convocou o herói e transferiu-lhe o centro de gravidade do seio da sociedade para uma região desconhecida ${ }^{355}$.

Nos contos de fadas e contos populares, a partida do órfão se dá no momento em que ocorre um desequilíbrio, induzindo o protagonista a iniciar sua trajetória; ou, ainda, como citado no primeiro capítulo desta dissertação, quando a "tranqüilidade épica" é abalada por uma "desgraça" ${ }^{\text {"356 }}$. Veremos de que maneira esse desequilíbrio inicial acontece nas três trajetórias aqui analisadas.

\footnotetext{
${ }^{354}$ CAMPBELL, Op. cit., 2002, p. 59.

${ }^{355}$ Idem, pp. 61-66.

${ }^{356}$ Cf. Cap. 1, p. 54.
} 
Das três personagens órfãs selecionadas para ilustrar este capítulo, Harry Potter é a que recebe o "chamado" de forma mais precoce, às vésperas de completar onze anos de idade. Na verdade é o único que recebe literalmente um chamado, por meio de uma carta, pela qual ele é convidado a matricular-se na Escola de Bruxaria de Hogwarts:

\author{
Prezado Sr. Potter \\ Temos o prazer de informar que V. Sa. tem uma vaga na Escola \\ de Magia e Bruxaria de Hogwarts. Estamos anexando uma lista \\ dos livros e equipamentos necessários. \\ $\mathrm{O}$ ano letivo começa em $1^{\circ}$ de setembro. Aguardamos sua coruja \\ até 31 de julho, no mais tardar ${ }^{357}$.
}

Porém antes que a carta-convite pudesse chegar a seu destinatário, os tios do pequeno bruxo - Valter e Petúnia -, responsáveis pela sua criação desde bebê, e que atuam em todo o enredo como "desvios" em seu caminho, tentam interceptar o "chamado" de diversas maneiras, usando artifícios pouco convencionais, como por exemplo lacrar a entrada de cartas da casa ou mesmo viajar com a família para uma ilha deserta para evitar - ou pelo menos retardar - a partida do herói:

O envelope era grosso e pesado, feito de pergaminho amarelado e endereçado com tinta verde-esmeralda. Não havia selo. Quando virou o envelope, com a mão trêmula, Harry viu um lacre de cera púrpura com um brasão; um leão e uma águia, um texugo e uma cobra circulando uma grande letra "H". (...) Harry ia desdobrar a carta, escrita no mesmo pergaminho grosso que o envelope, quando tio Valter arrancou-a de sua mão ${ }^{358}$.

\title{
(...)
}

Na sexta-feira chegaram nada menos de doze cartas para Harry. Como não passavam pela portinhola da correspondência tinham sido empurradas por baixo da porta, metidas pelos lados e algumas até forçadas pela janelinha do banheiro no térreo. Tio Valter ficou em casa de novo. Depois de queimar todas as cartas, apanhou martelo e pregos e fechou com tábuas as

\footnotetext{
${ }^{357}$ ROWLING, J. K. Harry Potter e a pedra filosofal, p. 49.

${ }^{358}$ Idem, pp. 34-35.
} 
frestas em volta das portas da frente e dos fundos, de modo que ninguém pudesse sair ${ }^{359}$.

(...)

No sábado as coisas começaram a fugir ao seu controle. Vinte e quatro cartas acabaram entrando em casa, enroladas e escondidas nas duas dúzias de ovos que o leiteiro, muito confuso, entregara à tia Petúnia pela janela da sala de estar. Enquanto tio Valter dava telefonemas furiosos para o correio e a leiteria tentando encontrar alguém a quem se queixar, tia Petúnia picava as cartas no processador de alimentos ${ }^{360}$.

Apesar de todo o esforço dos tios para evitar que o "chamado para a aventura" fosse atendido, Harry Potter consegue finalmente receber a carta de Hogwarts alguns dias depois pelas mãos do gigante Hagrid, que, de modo inverso ao dos tios de Harry, atua como importante "atalho" na jornada do novo herói.

Já Peter Parker não tem um chamado para a aventura autêntico. No início da HQ original, o jovem é apresentado como um adolescente rejeitado e alvo fácil de zombaria na escola. Sofre com o descaso de seus colegas e principalmente das garotas, pelo fato de não possuir atributos que o façam "especial"; pelo contrário, não é um tipo atlético, tem baixa estatura, usa óculos, e além disso tem a fama de "nerd"361. Por outro lado, diferentemente de Harry Potter, Peter Parker desfruta em casa do amor e do carinho dos tios - Ben e May - que o criam.

O "chamado para a aventura" ocorre somente quando Peter Parker encontra o tio assassinado por um tiro e descobre que o autor do disparo foi o mesmo ladrão que ele, com auxílio de seus poderes, poderia ter detido dias antes.

\footnotetext{
${ }^{359}$ Idem, p. 39.

${ }^{360}$ Idem, ibidem.

${ }^{361}$ A expressão usada pelos colegas no original é "bookworm" (traça de livros), que poderia ser traduzida também pela sigla C.D.F. (Cf. nota 310, p. 156).
} 
No último quadrinho do primeiro episódio de Homem-Aranha ${ }^{362}$, o

narrador revela ao leitor a entrada do jovem no rol dos super-heróis:

E uma figura fraca e silenciosa vagarosamente desaparece na escuridão, consciente pelo menos de que, neste mundo, um grande poder implica também grande responsabilidade! E assim nasce uma lenda e um novo nome é adicionado à galeria daqueles que fazem do mundo da fantasia o reino mais extraordinário de todos! $!^{363}$.

Como ocorre com Harry Potter e Peter Parker, também Luke Skywalker é criado por tios - Owen e Beru ${ }^{364}$. Na primeira cena em que o herói aparece no filme original criado por George Lucas, Episódio IV - Uma nova esperança (1977), encontramos o jovem órfão ajudando o tio na compra de andróides. É por meio de um desses andróides que Luke vem a conhecer a princesa Léia, mais tarde revelada como sua irmã.

Em casa, Luke não é desprezado como Harry Potter, mas não é tão adulado como Peter Parker. É um rapaz trabalhador e responsável, cujo maior desejo é cursar a Academia e tornar-se um piloto estelar. No roteiro original, a descrição de Luke é a de um adolescente - "um jovem fazendeiro, com aspirações heróicas, que parecia bem mais novo do que seus dezoito anos"365.

${ }^{362}$ Cf. Fig. 5, p. 159.

${ }^{363}$ Stan, L. \& DITKO, S. Op. cit., p. 13. ("And a lean, silent figure slowly fades into the gathering darkness, aware at last that in this world, with great power ther must also come - great responsability! And so a legend is born and a new name is added to the roster of those who make the world of fantasy the most exciting realm of all!")

${ }^{364} \mathrm{Na}$ última cena do último filme da segunda trilogia (Episódio VI - A vingança do Sith), o bebê Luke recém-nascido é entregue por Obi-Wan aos cuidados dos tios, Owen e Beru, que o criarão.

${ }^{365}$ Texto original do roteiro onde encontramos a descrição de Luke: "The tremendous heat of two huge twin suns settle on a lone figure, Luke Skywalker, a farm boy with heroic aspirations who looks much younger than his eighteen years. His shaggy hair and baggy tunic give him the air of a simple but lovable lad with a prize-winning smile" [grifo nosso]. Disponível em <http://www.blueharvest.net/scoops/anh-script.shtml> Acesso em 12/11/05. 
Em Guerra nas estrelas, o chamado para a aventura do herói é feito por meio do mestre Obi-Wan Kenobi, quando Luke é convidado pelo velho

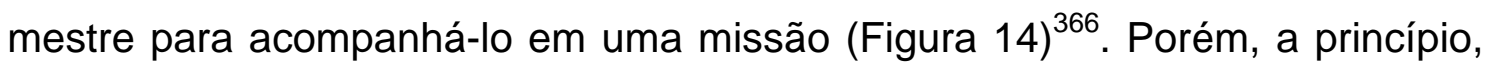
não querendo deixar os tios e suas responsabilidades, o jovem recusa o chamado:

- Você precisa aprender sobre a Força, Luke, se quiser me acompanhar a Alderaan!

- Alderaan! Eu não vou para Alderaan. Eu nem sei onde fica Alderaan. Eu tenho que voltar para casa. Está tarde (...)

- Eu preciso de sua ajuda, Luke. (...) Estou muito velho para esse tipo de coisa.

- Eu não posso me envolver! Eu tenho meu trabalho! Não que eu goste do Império, eu o odeio, mas não há nada que eu possa fazer. Isso não tem nada a ver comigo...

- Você parece seu tio falando...

(...)

- Olhe, eu poderia levá-lo até Anchorhead. Lá você pegaria uma condução para Mos Eisley, ou para onde quiser ${ }^{367}$.

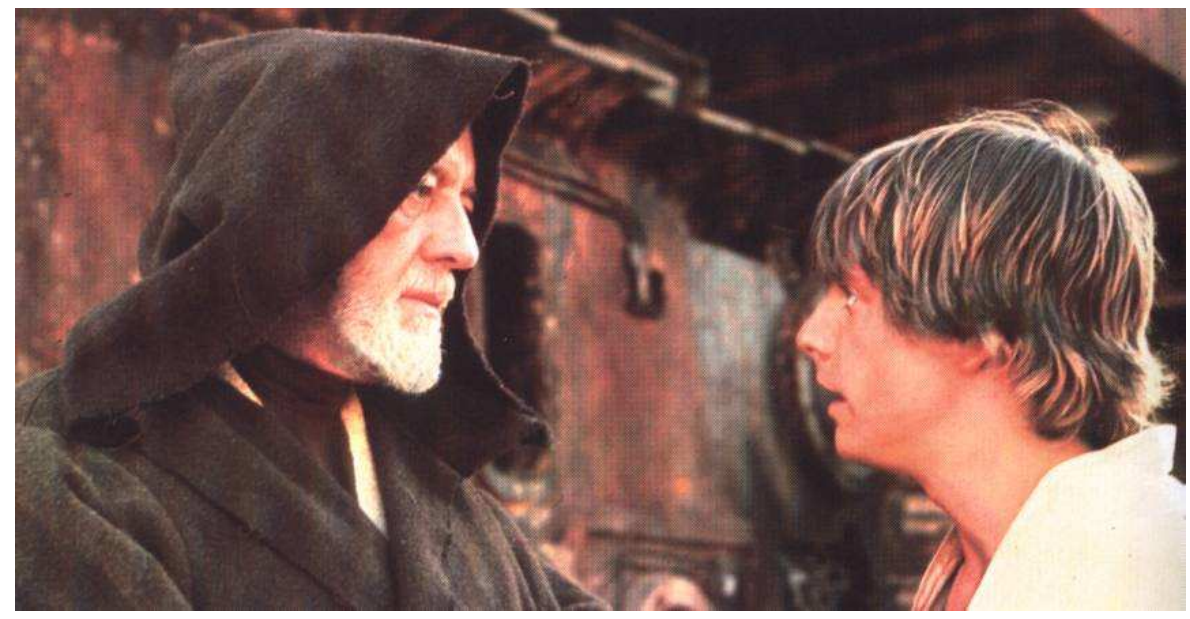

Figura 14 - Luke recebe o "chamado para a aventura" por meio de Obi-Wan Kenobi em Guerra nas estrelas - Episódio IV - Uma nova esperança, 1977.

${ }^{366}$ No início do filme, Obi-Wan é conhecido como Ben, um ermitão. Apenas mais tarde sua verdadeira identidade é revelada; no entanto Luke sempre se refere a ele como "Ben".

${ }^{367}$ Cena transcrita do filme Guerra nas Estrelas - Episódio IV - Uma nova esperança, 1977 (diálogo entre Luke Skywalker e Obi-Wan Kenobi). ["BEN: You must learn the ways of the Force if you're to come with me to Alderaan. LUKE: Alderaan? I'm not going to Alderaan. I've got to go home. It's late (...). BEN: I need your help, Luke. (...). I'm getting too old for this sort of thing. LUKE: I can't get involved! I've got work to do! It's not that I like the Empire. I hate it! But there's nothing I can do about it right now. It's such a long way from here. BEN: That's your uncle talking. (...) LUKE: Look, I can take you as far as Anchorhead. You can get a transport there to Mos Eisley or wherever you're going"]. Roteiros disponíveis em $<$ http://www.blueharvest.net/scoops/anh-script.shtml>. Acesso em 30/11/2005. 
Joseph Campbell explica essa recusa do chamado da seguinte maneira:

Com freqüência, na vida real, e com não menos freqüência, nos mitos e contos populares, encontramos o triste caso do chamado que não obtém resposta; pois sempre é possível desviar a atenção para outros interesses. A recusa à convocação converte a aventura em sua contraparte negativa. Aprisionado pelo tédio, pelo trabalho duro ou pela "cultura", o sujeito perde o poder da ação afirmativa dotada de significado e se transforma numa vítima a ser salva ${ }^{368}$.

A seguir, ao explicar em linhas gerais o "chamado para a aventura", Campbell afirma que o herói pode agir por vontade própria na realização da aventura ou "pode ser levado ou enviado para longe por algum agente benigno ou maligno"369.

No caso de Harry Potter, o pequeno bruxo é conduzido de forma "benigna" para longe da família que o criou, e é por vontade própria que se dá sua partida. Também Luke Skywalker parte por vontade própria, depois do assassinato de seus tios, acompanhando seu mestre e tutor Obi-Wan Kenobi. Apenas Peter Parker não é realmente "conduzido" por ninguém, sendo - nesse momento inicial - o mais solitário entre os três heróis.

Campbell acrescenta ainda outras características comuns no início da trajetória do herói, afirmando ser o lugar para onde ele se dirige geralmente "habitado por seres estranhamente fluidos e polimorfos, tormentos inimagináveis, façanhas sobre-humanas e delícias impossíveis”370.

\footnotetext{
${ }^{368}$ CAMPBELL, J. Op. cit., 2002, pp. 66-67.

369 Idem, p. 66.

${ }^{370}$ Idem, ibidem.
} 
Nada é mais parecido com essa definição do que a jornada de Harry Potter para a imprevisível realidade dos bruxos: deixando para trás a "normalidade" em que foi criado, o pequeno aprendiz passa a descobrir um mundo paralelo, começando pelo Beco Diagonal, a "rua dos bruxos", localizada em Londres, até a chegada ao castelo de Hogwarts, cujo acesso é possível por meio de um trem que parte da Plataforma $912^{371}$, um lugar invisível aos olhos humanos normais e inatingível para aqueles que não são bruxos. Nessa nova realidade, Harry Potter passará a conviver com duendes, gigantes, elfos, magos, ogros e uma infinidade de animais e seres mitológicos, como por exemplo o unicórnio, a fênix e o centauro.

Também Luke Skywalker deixa para trás uma vida banal e pacata no planeta desértico Tatooine para embarcar na nave Falcon rumo a Alderaan, com a missão de resgatar a Princesa Léia das mãos do Império e restituir-lhe os planos roubados da Estrela da Morte. No seu caminho, Luke encontrará muitos alienígenas, alguns "benignos", outros "malignos", entre eles, Ewoks e Jawas.

Dos três heróis, Peter Parker é o que menos se distancia de seu lar primitivo a partir do chamado para a aventura. A real transformação em sua rotina se dá pela variedade de seres com quem passa a conviver. Como um jovem comum, Peter Parker apenas contracenava com outros adolescentes e adultos. Como Homem-Aranha, passa a conviver com toda sorte de heróis e inimigos, como Quarteto-Fantástico, Duende Verde, Dr. Octopus, Dr. Cobbwell, Dr. Doom, Homem-Areia, entre outros.

${ }^{371}$ Em inglês, Platform 933/4. 
Para finalizar essa análise sobre "a partida”, é também interessante pormenorizar o início da jornada do herói nesses três enredos a partir do chamado para a aventura.

$\mathrm{Na}$ análise de contos populares realizada no primeiro capítulo desta dissertação, vimos que a própria orfandade do herói pode configurar esse chamado $^{372}$.

A aventura de Harry Potter tem início quando ele cruza o limiar entre o real e o maravilhoso na Plataforma 91/2. Ao deixar a estação King's Cross para trás, o jovem órfão parte no Expresso de Hogwarts para tentar encontrar, como o Patinho Feio, sua verdadeira identidade e seu lugar no mundo. A orfandade do herói não é, portanto, o motivo de sua partida, mas a falta de amor em seu lar não o faz titubear em aceitar prontamente o chamado.

Porém tanto no caso de Luke como no de Peter Parker não é primeira orfandade que estimula a partida dos heróis, mas a segunda. No início de ambos os enredos, diferentemente do que ocorre em Harry Potter, os órfãos não são maltratados ou sofrem de privações. Pelo contrário, têm como arrimo familiar tios "bons"373, que, inesperadamente, são assassinados e tirados de seu convívio ${ }^{374}$, fato que deixa os jovens duplamente órfãos. Nos dois casos analisados, é essa segunda orfandade o principal motivo que leva os heróis agora ainda mais solitários - a aceitarem o desafio do chamado para a aventura.

${ }^{372}$ Cf. Cap. 1, p. 43.

373 Tanto para Peter como para Luke, os tios poderiam ser considerados "atalhos" em sua trajetória, uma vez que são do tipo "protetores" e cuidam dos órfãos na ausência dos pais; não é o que acontece com Harry Potter, por exemplo, cujos tios fazem papel de "desvios", como as madrastas dos contos de fadas (Sobre os termos "desvios" e "atalhos", cf. Cap. 2).

${ }^{374}$ No caso de Peter Parker, apenas o tio é assassinado; enquanto Luke perde ambos os tios, além de sua casa, em um incêndio criminoso. 
Se para Peter Parker a presença do tio não configurava um problema para ele agir como Homem-Aranha, para Luke, essa presença era um empecilho real para sua partida, como é possível perceber no primeiro diálogo entre o herói e Obi-Wan (Figura 14):

- Você parece seu tio falando...

- Oh, Deus, meu tio! Como eu vou explicar isso a ele? ? $^{375}$

Porém a partir do momento em que encontra em casa tudo destruído e seus tios, mortos, o jovem Luke torna a ir ao encontro do seu futuro mestre e reconsidera o chamado, não tendo mais motivos para deixar de partir:

- Irei com você para Alderaan. Não me resta mais nada aqui. Eu quero aprender sobre a Força e me tornar um Jedi como meu $\mathrm{pai}^{376}$.

A partir do "chamado para a aventura" - ou da "recusa do chamado" Campbell propõe o próximo passo para a jornada do herói: "o auxílio sobrenatural":

Para aqueles que não recusaram o chamado, o primeiro encontro da jornada do herói se dá com uma figura protetora (que com freqüência é uma anciã ou um ancião), que fornece ao aventureiro amuletos que o protejam contra as forças titânicas com que ele está prestes a deparar-se ${ }^{377}$.

\footnotetext{
${ }^{375}$ Cena transcrita do filme Guerra nas Estrelas - Episódio IV - Uma nova esperança, 1977 (diálogo entre Luke Skywalker e Obi-Wan Kenobi). ["BEN: That's your uncle talking. LUKE: (sighing) Oh, God, my uncle. How am I ever going to explain this?"] Disponível em: <http://www.blueharvest.net/scoops/anh-script.shtml>. Acesso em 25/10/05.

${ }^{376}$ Cena transcrita do filme Guerra nas Estrelas - Episódio IV - Uma nova esperança, 1977. (diálogo entre Luke Skywalker e Obi-Wan Kenobi). Diálogo original em inglês: "LUKE: I want to come with you to Alderaan. There's nothing here for me now. I want to learn the ways of the Force and become a Jedi like my father". Disponivel em <http://www.blueharvest.net/ scoops/anh-script.shtml>. Acesso em 25/10/05.

${ }^{377}$ CAMPBELL, J. Op. cit., 2002, p. 74.
} 
Dos três heróis avaliados neste capítulo, apenas Peter Parker não tem um protetor em sua jornada, tampouco amuletos ou armas especiais, além de seus superpoderes.

Harry Potter e Luke Skywalker contam, respectivamente, com as figuras protetoras de Hagrid $^{378}$ e Obi-Wan. São eles os responsáveis por conduzirem os órfãos no momento da partida e por meio deles os heróis começam a tomar contato com algumas "verdades" sobre sua nova realidade.

Um exemplo disso é o fato de Hagrid e Obi-Wan serem os primeiros a desmentir as histórias inventadas pelos tios de Harry e Luke, respectivamente, acerca da morte de seus pais, fazendo as revelações iniciais aos heróis.

Em Harry Potter e a pedra filosofal, em uma discussão entre Hagrid e os tios, Petúnia é coagida pelo gigante a contar ao órfão toda a verdade sobre o passado de seus pais:

- Então ela conheceu Potter na escola e eles saíram de casa, casaram e tiveram você, e é claro que eu sabia que você ia ser igual, esquisito, anormal, e então ela vai e me faz o favor de se explodir e nos deixar entalados com você!

Harry ficara muito branco. Assim que encontrou a voz, disse:

- Se explodir? Você me disse que eles morreram num acidente de carro!

- ACIDENTE DE CARRO! - rugiu Hagrid (...) - Como é que um acidente de carro poderia matar Lílian e Tiago Potter! Isso é um absurdo! Um escândalo! E Harry Potter não conhecer a própria história, quando qualquer garoto no nosso mundo conhece o nome dele! $!^{379}$

Um pouco adiante, o próprio Hagrid esclarece ao herói um pouco

mais a respeito da morte de seus pais:

Ora, sua mãe e seu pai eram os melhores bruxos que eu já conheci. Primeiros alunos em Hogwarts no seu tempo! Suponho que o mistério era por que Você-Sabe-Quem nunca tentou convencer os dois a se aliar a ele antes... provavelmente sabia que eram muito chegados a Dumbledore para querer alguma

\footnotetext{
${ }^{378}$ A figura de Hagrid é mais tarde substituída pela de Dumbledore, que passa a desempenhar o papel de protetor do herói após o ingresso de Harry Potter em Hogwarts.

${ }^{379}$ ROWLING, J. K. Harry Potter e a pedra filosofal, p. 51.
} 
coisa com o lado das Trevas. (...) Só o que sabemos é que ele apareceu na vila em que vocês estavam morando, num dia das bruxas, faz dez anos. Na época você só tinha um ano de idade. Ele foi a sua casa e... e... (...) Você-Sabe-Quem matou os dois! ! $^{380}$

Em Guerra nas estrelas, depois de muito tempo acreditando em uma realidade bem diferente, Luke tem o primeiro acesso à história de seu pai por meio de Obi-Wan:

- Meu pai não lutou na Guerra. Ele era piloto de um cargueiro.

- Isso é o que seu tio lhe contou. Ele não concordava com os ideais de seu pai. Achou melhor ficar aqui e não se envolver...

- Você lutou nas Guerras Clônicas?

- Sim, eu era um Cavaleiro Jedi, como seu pai.

- Eu gostaria de tê-lo conhecido...

- Ele era o melhor piloto em toda a Galáxia. Um guerreiro astucioso... Eu soube que você também se tornou um bom piloto. $\mathrm{E}$ ele era um bom amigo... ${ }^{381}$

Também Luke demonstra interesse por conhecer a verdadeira história

do pai, e pede a Obi-Wan mais detalhes sobre a sua morte. Como viremos a saber mais tarde, o velho mestre não conta tudo o que sabe ao herói, poupando-o da dos verdadeiros fatos, de que ele só teria conhecimento mais tarde $e^{382}$ :

- Como meu pai morreu?

- Um jovem Jedi chamado Darth Vader, que foi meu aprendiz antes de passar para outro lado, ajudou o Império a perseguir e a destruir todos os Cavaleiros Jedi. Ele traiu e matou seu pai. Agora os Jedi estão quase todos extintos... Vader foi atraído pelo lado negro da Força $^{383}$.

${ }^{380}$ Idem, pp. 52-53.

${ }^{381}$ Cena transcrita do filme Guerra nas estrelas - Episódio IV - Uma nova esperança, 1977 (diálogo entre Luke Skywalker e Obi-Wan Kenobi). [ "LUKE: No, my father didn't fight in the wars. He was a navigator on a spice freighter. BEN: That's what your uncle told you. $\mathrm{He}$ didn't hold with your father's ideals. Thought he should have stayed here and not gotten involved. LUKE: You fought in the Clone Wars? BEN: Yes, I was once a Jedi Knight the same as your father. LUKE: I wish I'd known him. BEN: He was the best star-pilot in the galaxy, and a cunning warrior. I understand you've become quite a good pilot yourself. And he was a good friend"]. Disponível em <http://www.blueharvest.net/scoops/anh-script.shtml>. Acesso em 25/10/05.

382 Apenas no Episódio V Luke descobre a verdade sobre seu pai, Anakin Skywalker, que cedeu ao lado negro da Força e tornou-se Darth Vader, seu maior inimigo.

${ }^{383}$ Cena transcrita do filme Guerra nas Estrelas - Episódio IV - Uma nova esperança, 1977. (diálogo entre Luke Skywalker e Obi-Wan Kenobi). ["LUKE: How did my father die? BEN: A young Jedi named Darth Vader, who was a pupil of mine until he turned to evil, helped the Empire hunt down and destroy the Jedi Knights. He betrayed and murdered your father. Now 
É também por meio de seus "protetores" que Harry e Luke irão obter as poderosas armas com as quais passarão a lutar para vencer seus inimigos. Enquanto Hagrid conduz Harry à loja do Sr. Olivaras para adquirir sua varinha, a arma dos bruxos, Obi-Wan entrega a Luke um sabre de luz, a "espada" dos Cavaleiros Jedi, que pertencera a seu pai (Figura 15).
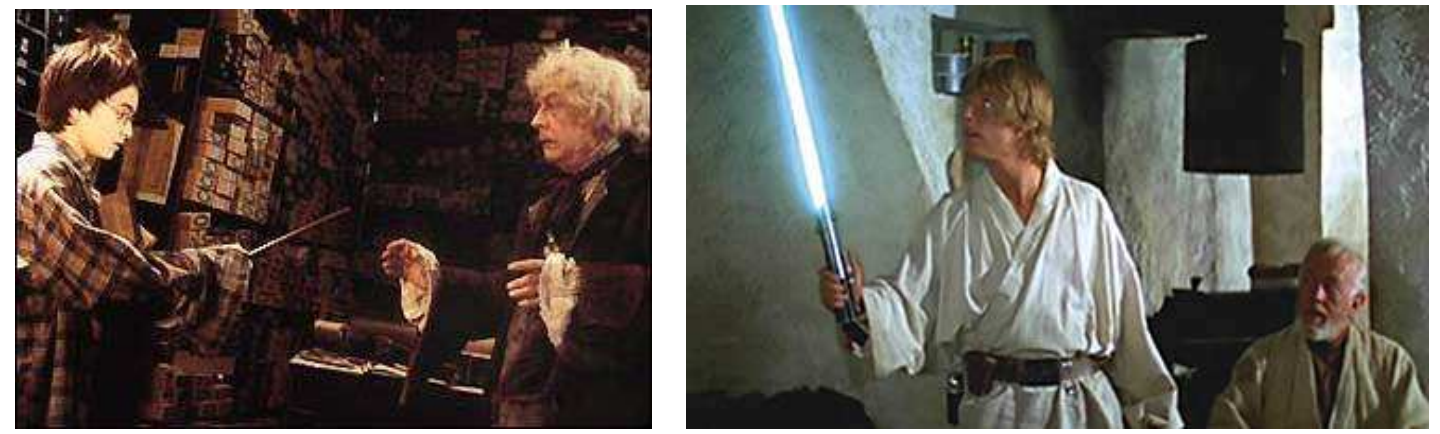

Figura 15 - Harry testa sua varinha na loja de Olivaras, em cena do filme Harry Potter e a pedra filosofal (à esquerda); Luke recebe o sabre de luz que foi de seu pai das mãos de Obi-Wan Kenobi em Guerra nas estrelas - Episódio IV - Uma nova esperança, 1977 (à direita).

Ainda com a ajuda de seus protetores, os heróis órfãos ultrapassam a barreira do "primeiro limiar"384. Em Harry Potter, essa barreira é representada pela Plataforma 91/2, de onde partirá o trem para Hogwarts. Em Guerra nas estrelas, pela nave Falcon, que conduz Luke e Obi-Wan para longe de Tatooine.

Uma vez dado o primeiro passo, caberá agora ao herói prosseguir em sua trajetória rumo ao desconhecido e às "trevas inexploradas".

the Jedi are all but extinct. Vader was seduced by the dark side of the Force"]. Disponível em <http://www.blueharvest.net/scoops/anh-script.shtml>. Acesso em 25/10/05.

384 Campbell considera o "primeiro limiar" o limite entre o mundo conhecido e a área caracterizada "pelas trevas, pelo desconhecido e pelo perigo" (CAMPBELL, J. Op. cit., 2002, p. 82). 


\subsubsection{Iniciação}

Non est ad astra mollis e terris via.

Não há caminho fácil entre a terra e as estrelas.

(Sêneca)

A sabedoria popular enfatiza a importância de se dar o "primeiro passo", não importando a dimensão da jornada. Diz um provérbio chinês: "Uma caminhada de mil léguas começa sempre com o primeiro passo". Bastante semelhante é a filosofia de Lao-Tsé: “Uma longa viagem começa com um único passo"385.

Ao herói, porém, após o "chamado para a aventura" e sua partida, restará ainda um longo caminho pela frente, repleto de provas, desvios e atalhos. Tanto na mitologia, como na literatura, nos quadrinhos ou no cinema, quanto mais árdua sua trajetória, maiores os feitos e as glórias do herói.

Quando Harry Potter parte pela primeira vez no Expresso de Hogwarts $^{386}$ para um mundo novo a ser descoberto, ainda não faz idéia de que seria submetido a uma enorme quantidade de provas, além dos exames finais propostos por seus professores ${ }^{387}$. As mais importantes dessas provas - os confrontos com o vilão Voldemort -, apesar de deixarem marcas psicologicamente indeléveis no herói, tornam-no mais capacitado para

385 Disponível em <http://www.joselaerciodoegito.com.br/tao_verso_64.htm>. Acesso em 31/12/05.

${ }^{386}$ ROWLING, J. K. Harry Potter e a pedra filosofal, pp. 80-100.

${ }^{387}$ Como Hogwarts é, acima de tudo, uma escola, é normal os alunos esperarem que haja exames como forma de avaliação de seu desempenho durante o ano. 
prosseguir em sua jornada, fortalecendo-o e criando a situação ideal para a grande batalha, que ocorrerá sem dúvida no capítulo final da saga (Livro 7) ${ }^{388}$.

Já Peter Parker, após ter assumido uma nova identidade como Homem-Aranha, tem crescentes provas a realizar e diferentes inimigos a enfrentar. A cada novo episódio de sua $H Q$, os vilões tornam-se mais fortes e cada vez mais ousados, desafiando a coragem e o expediente do super-herói, e impedindo o jovem adolescente que existe por trás da máscara de levar uma vida "normal".

Também Luke Skywalker vê a sua vida mudar radicalmente após sua partida. Aos poucos descobre o poder da Força e aprende a usar o sabre de luz, a arma dos Cavaleiros Jedi. Guiado por seu mestre, Obi-Wan Kenobi, o herói parte para várias aventuras, entre elas o resgate de uma princesa e inúmeras batalhas espaciais. Porém as maiores de todas as suas provas são, sem dúvida, os duelos travados com seu pai, o temível Darth Vader, que ocorrem no final dos Episódios $\mathrm{V}$ e $\mathrm{VI}{ }^{389}$.

Campbell define a segunda parte da jornada como um período de "iniciação" ${ }^{390}$, no qual haverá as provas a serem vencidas entre outros temas recorrentes, como o auxílio "sobrenatural", o resgate da princesa ou o "encontro com a mulher amada", compreendendo principalmente um período de auto-afirmação para o herói.

${ }^{388}$ Embora o sétimo livro ainda não tenha título definido nem data de lançamento (estima-se que seja publicado entre o final de 2006 e meados de 2007), é bastante provável que o epílogo da saga de Harry Potter traga um duelo definitivo entre o herói e o vilão.

${ }^{389}$ No final do Episódio V - O Império contra-ataca -, Luke enfrenta Darth Vader sozinho em um duelo. Embora ferido, o herói consegue escapar com a ajuda de seus amigos. É nesse confronto que o vilão revela a Luke sua verdadeira identidade. No final do Episódio $\mathrm{VI}-\mathrm{O}$ retorno de Jedi -, Luke novamente enfrenta o pai, vencendo-o. Antes de morrer nos braços do filho, Darth Vader salva-o da fúria do Imperador, redimindo-se.

${ }^{390}$ CAMPBELL, J. Op. cit., 2002, pp. 102-194. 
Começaremos a análise desse período de iniciação por meio dos atalhos que conduzem o herói por seu "caminho de provas".

Harry Potter chega a Hogwarts com o rótulo de "o menino que sobreviveu". Desse modo, ao mesmo tempo que desperta admiração e respeito de colegas e professores, é alvo de inveja e ciúme por parte de outros.

Peter Parker também é amado e odiado ao mesmo tempo na pele de Homem-Aranha. Enquanto várias pessoas creditam ao herói as glórias pelas façanhas que realiza, outras o perseguem e o acusam, colocando sempre em dúvida seu caráter e suas reais intenções.

Entre os três heróis aqui analisados, Luke Skywalker é o menos contestado de todos, adquirindo pouco a pouco a consideração e o respeito tanto de seus amigos, como de seus inimigos. É um típico aprendiz que, em meio a seus acertos e erros, e mesmo após a morte de Obi-Wan, seu guia e protetor, não esmorece e não abandona seus objetivos.

Campbell acredita que, nesses primeiros movimentos no período de iniciação, o herói é muitas vezes conduzido por auxílio de amuletos ou objetos mágicos, possivelmente aqueles mesmos oferecidos a ele antes de sua passagem pelo primeiro limiar:

Tendo cruzado o limiar, o herói caminha por uma paisagem onírica povoada por formas curiosamente fluidas e ambíguas, na qual deve sobreviver a uma sucessão de provas. (...) O herói é auxiliado, de forma encoberta, pelo conselho, pelos amuletos e pelos agentes secretos do auxiliar sobrenatural que havia encontrado antes de penetrar nessa região. Ou, talvez, ele aqui descubra, pela primeira vez, que existe um poder benigno, em toda parte, que o sustenta em sua passagem sobre-humana ${ }^{391}$. 
Harry Potter - até pelo fato de ser um bruxo e viver em um ambiente em que impera a magia - talvez seja a personagem que conta com mais objetos mágicos a seu dispor. Após sua entrada no mundo dos bruxos, além dos acessórios que já havia adquirido com a ajuda inicial de Hagrid, Harry assim como Luke - recebe como presente algo que pertencera a seu pai: a capa da invisibilidade, que lhe será muito útil em diversas ocasiões.

Outro objeto mágico com o qual Harry é presenteado é uma vassoura voadora, oferecida pela bruxa Minerva. Todos esses "amuletos" iniciais, somados aos que vão aparecendo durante os outros livros da série - como, por exemplo, a espada de Gryffindor (livro 2) ${ }^{392}$ ou o mapa do maroto ${ }^{393}$ e o viratempo (livro 3) $)^{394}$ - auxiliam o herói a superar seus obstáculos e suas dificuldades, transformando-se em importantes atalhos na busca de seus objetivos.

Ao contrário de Harry Potter, Peter Parker é a personagem que menos conta com objetos mágicos, talvez pelo fato de ser um super-herói e não precisar de nada além de seus próprios poderes (boa visão, agilidade, habilidade para subir em paredes, força e velocidade). Seu único "acessório" contra os inimigos é um mecanismo que ele mesmo constrói para soltar uma "teia"395, utilizado tanto para sua própria fuga e locomoção como para capturar os bandidos (Figura 16).

\footnotetext{
${ }^{392}$ ROWLING, J. K. Harry Potter e a câmara secreta, pp. 269-280.

${ }^{393}$ ROWLING, J. K. Harry Potter e o prisioneiro de Azkaban, pp. 152-173.

${ }^{394}$ Idem, pp. 316-318.

${ }^{395}$ No filme Spiderman (2002), a habilidade de soltar teia faz parte do conjunto de "sintomas" ligados ao aracnídeo que o herói adquire quando é picado. Nos quadrinhos, é o próprio Peter Parker quem confecciona o mecanismo que "solta" a teia.
} 

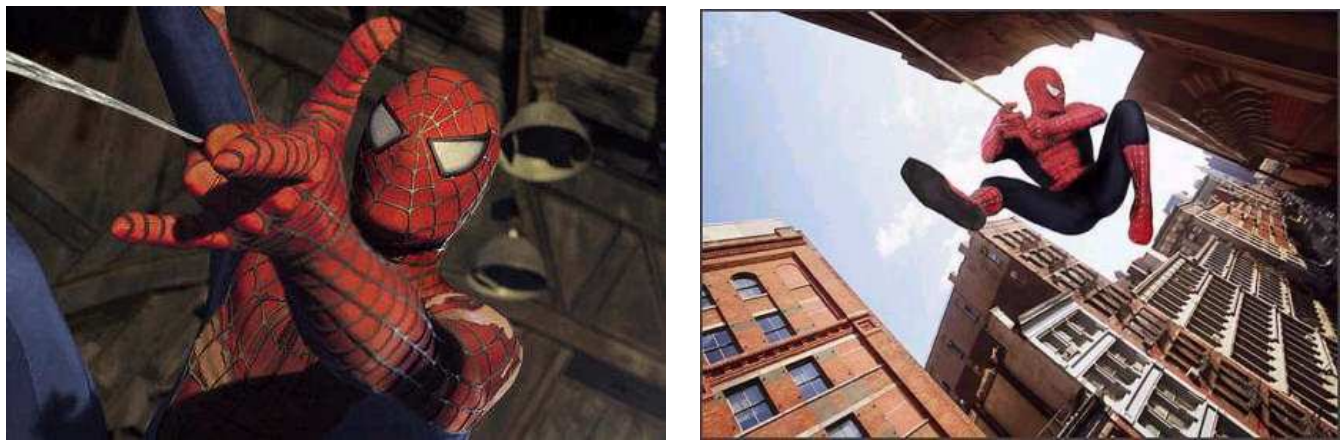

Figura 16 - Peter Parker como Homem-Aranha usa sua teia para atacar os inimigos (esquerda) e se locomover (direita), em cenas do filme Sipderman 2, 2004.

Para Luke Skywalker, o sabre de luz que fora de seu pai é o único objeto mágico que acompanha o órfão desde a sua partida. A arma Jedi é uma poderosa espada e sua lâmina a laser, além de cortar, desvia raios e balas provenientes de armas de fogo, servindo como arma e escudo ao mesmo tempo.

A partir da passagem pelo primeiro limiar, Luke começa a conhecer mais sobre a Força, "uma energia positiva que emana de todos os seres vivos e mantém a Galáxia unida”396, segundo a definição do próprio Obi-Wan Kenobi em Episódio IV - Uma nova esperança. A Força passa então a ser para Luke um novo e importante atalho em seu longo caminho de provas.

Outro fator bastante recorrente como atalho na jornada do herói é a presença de amigos verdadeiros e leais. Das personagens aqui analisadas, novamente é Peter Parker quem mais se distancia das outras duas, não contando com amigos propriamente ditos logo nos primeiros episódios ${ }^{397}$.

396 ["The Force is what gives a Jedi his power. It's an energy field created by all living things. It surrounds us and penetrates us. It binds the galaxy together"]. Disponível em <http://www.blueharvest.net/scoops/anh-script.shtml >. Acesso em 25/10/05.

397 Mais tarde registramos o aparecimento de personagens que podem ser consideradas amigos - e atalhos - na vida do super-herói; porém como estamos analisando aqui somente os episódios iniciais, esse fato não será relevado. 
Mais uma vez é Harry Potter aquele que mais usufrui desse importante atalho em seu caminho. Em seu rol de amigos, estão o gigante Hagrid, seu primeiro protetor, o mago Dumbledore, que a cada livro torna-se uma peça mais importante na vida do herói, a família Wesley, que o "adota”398, além dos bruxos Sirius e Lupin (a partir do livro 3), apenas para citar algumas personagens que desempenham esse papel. Porém os exemplos mais fiéis de amigos inseparáveis do pequeno bruxo são os colegas Rony e Hermione, companheiros para (quase) todas as aventuras e perigos (Figura 17).
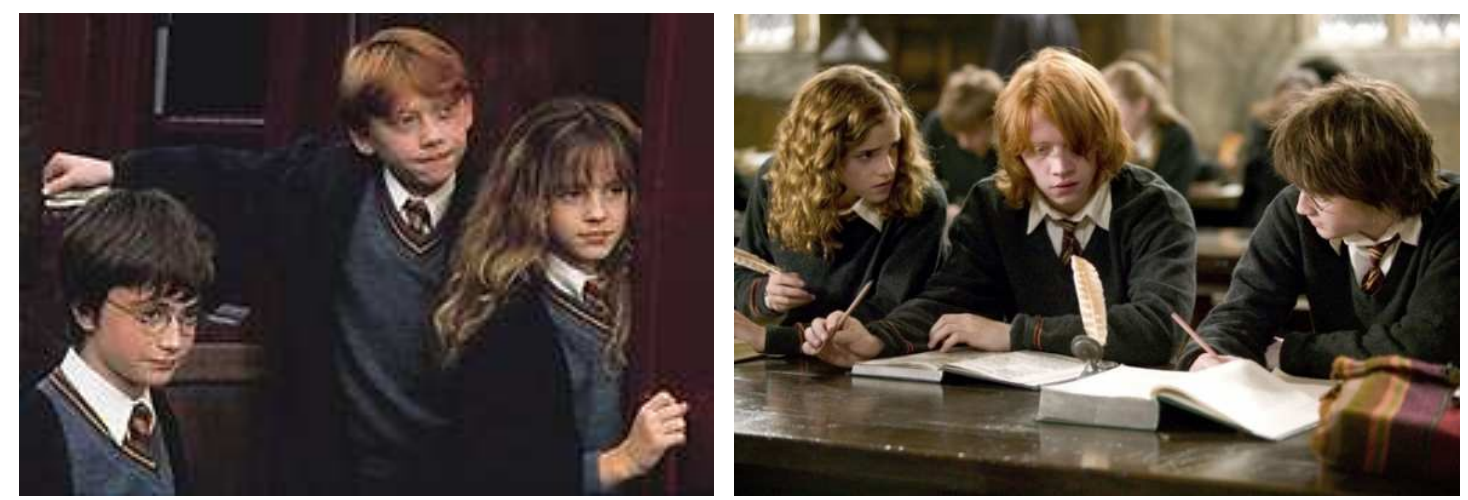

Figura 17 - Os atores Daniel Hadcliff, Rupert Grant e Emma Watson interpretam, respectivamente, Harry Potter e seus amigos Rony e Hermione. Cenas dos filmes Harry Potter e a pedra filosofal (2001), quando ainda eram crianças (à esquerda), e Harry Potter e o cálice de fogo (2005), já como adolescentes (à direita).

Rony é na verdade o primeiro colega com quem Harry faz amizade, logo que o herói cruza o primeiro limiar de sua trajetória, dentro do trem que leva os alunos a Hogwarts. É Rony também o companheiro escolhido por Harry para confidências e aventuras, para dividir alegrias e tristezas. Algumas vezes Rony sente ciúmes de Harry, pelo fato de o herói ser sempre alvo das

${ }^{398}$ A família Wesley a que nos referimos são os pais de Rony - Arthur e Molly - e seus irmãos, entre eles os gêmeos Fred e Jorge, que facilitam a vida de Harry ao presenteá-lo com o "mapa do maroto" (em ROWLING, J. K. Harry Potter e o prisioneiro de Azkaban) e Gina, a irmã caçula que despertará o amor do pequeno bruxo no sexto livro da série (Harry Potter e o enigma do príncipe). Usamos o termo "adota" no sentido figurado e sentimental, uma vez que Molly Wesley manifesta sentimentos maternais para com o órfão e o presenteia da mesma forma que faz com os filhos. 
atenções $^{399}$, porém o inverso também é verdadeiro, pois muitas vezes Harry desejou ter uma família completa e saudável como a do amigo.

Já Hermione é uma amiga do tipo mais útil ao herói. Extremamente estudiosa e responsável, a menina é fundamental para tirar Harry das mais difíceis situações, como por exemplo para escapar das armadilhas que protegiam a pedra filosofal (livro 1) ${ }^{400}$, na preparação da poção polissuco (livro $2)^{401}$, no uso do vira-tempo (livro 3) ${ }^{402}$, apenas para citar alguns exemplos.

O trio de amigos formado no primeiro livro provavelmente continuará junto até o final da saga, exceto se a autora reservar para o herói uma perda ainda maior do que as que ele já vem sofrendo até este ponto da narrativa ${ }^{403}$.

Outro trio que se constrói em um relacionamento de amizade é o formado por Luke, Léia e Han Solo em Guerra nas estrelas (Figura 18). No final do Episódio IV, quando ambos, Luke e Han Solo, são condecorados pela princesa, existe uma expectativa de que haveria um triângulo amoroso formado pela mocinha, o herói e o "amigo".

${ }^{399}$ Como por exemplo em Harry Potter e o cálice de fogo, quando Rony se sente traído e desprezado pelo amigo quando Harry é escolhido para competir em um torneio (ROWLING, J. K. Harry Potter e o cálice de fogo, pp. 228-286).

400 Após passar pelo cão de três cabeças, para conseguir a pedra filosofal, Harry Potter enfrenta uma série de provas, para as quais conta com a ajuda inestimável de Rony e, principalmente, de Hermione, sem a qual não teria conseguido chegar à pedra, e salvá-la das mãos de Voldemort (ROWLING, J. K. Harry Potter e a pedra filosofal, pp. 235-244).

${ }^{401}$ Para conseguir pistas sobre o monstro que assombrava o castelo, Harry e Rony disfarçamse de Crabbe e Goyle, amigos de Malfoy, mas para isso contam com a habilidade de Hermione em preparar a poção polissuco (ROWLING, J. K. Harry Potter e a câmara secreta, pp. 183-193).

402 Para conseguir salvar Bicuço e Sirius da morte, Harry e Hermione voltam no tempo com a ajuda do vira-tempo, objeto que somente a astuciosa menina sabia usar (ROWLING, J. K. Harry Potter e o prisioneiro de Azkaban, pp. 152-173).

403 Conforme Harry vai crescendo aumentam seus poderes e sua responsabilidade, e aos poucos ele deixa de contar com aqueles que o protegiam, como por exemplo o padrinho Sirius (que morre no final do livro 5) e o mago Dumbledore (que morre no final do livro 6). Há quem aposte que outras mortes ocorrerão no último livro, incluindo a morte do próprio herói ou de seus amigos mais próximos. 
No entanto, à medida que a história evolui, Luke parte para seu treinamento como Jedi, deixando o caminho livre para Solo. O enredo não poderia ter tomado melhor direção, uma vez que, apenas no Episódio VI, Léia e Luke tomam conhecimento de que, na verdade, eram irmãos.
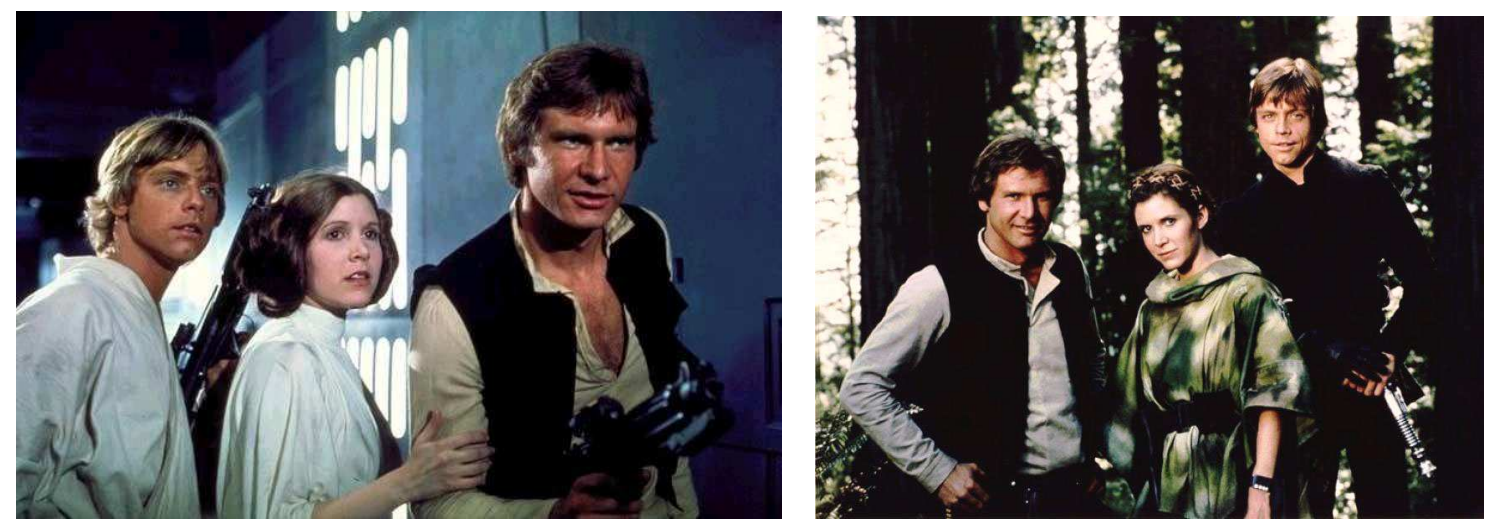

Figura 18 - Aliança rebelde liderada por Luke Skywalker, Léia Organa e Han Solo (interpretados por Mark Hamil, Carrie Fisher e Harrison Ford, respectivamente) em cena do Episódio IV - Uma nova esperança, 1977 (à esquerda); o trio comemora a vitória sobre o Império no último Episódio de Guerra nas Estrelas (Foto de divulgação do Episódio VI - O retorno de Jedi, 1983, à direita).

Mary Henderson, autora de Star Wars: the magic of myth, acredita que "o parceiro do herói é tão antigo quanto a primeira aventura de um herói”404, referindo-se à mitologia grega. Sobre Guerra nas estrelas, acrescenta:

Para encontrar seus parceiros ideais, Ben e Luke têm que descer das ruas de Mos Eisley para o mundo escuro e misterioso da taverna, um lugar escuso para piratas do espaço e aventureiros $^{405}$.

Han Solo aparece pela primeira vez no Episódio IV como um autêntico anti-herói, cuja única função é a de conduzir Luke e Obi-Wan em sua missão para Alderaan. No entanto, com a destruição do planeta, os planos são

\footnotetext{
${ }^{404}$ HENDERSON, M. Op. cit., p. 39. ["The hero partner is as old as the first written hero tale"].

${ }^{405}$ Idem, ibidem. ["To find their hero partners, Ben and Luke must descend from the streets of Mos Eisley into the dark, mysterious world of the cantina, a gathering place for sapceborne pirates and adventurers"].
} 
alterados e o foco da missão se direciona para o resgate da princesa Léia, por quem o aventureiro se apaixona. Mesmo demonstrando as fraquezas típicas de um mercenário arrogante e sem caráter, Han Solo conquista a simpatia do público e o reconhecimento dos heróis por sua valentia e audácia. Nos Episódios V e VI sua participação no enredo é ainda maior, sendo o "amigo" um atalho fundamental para que o herói possa atingir seus objetivos.

Léia Organa aparece pela primeira vez como refém de Darth Vader, a quem Luke e Obi-Wan devem resgatar. Ao contrário da fragilidade encontrada nas princesas de contos de fadas, os principais atributos da jovem são sua coragem, astúcia e lealdade. Diferentemente de Han Solo, que a princípio age em prol de Luke apenas por interesse, Léia torna-se rapidamente uma amiga e companheira que compartilha dos mesmos ideais do herói e, por isso, não titubeia em ajudá-lo, participando de suas aventuras e correndo riscos por ele. No último episódio da trilogia original, Luke e Léia finalmente descobrem que são irmãos gêmeos, e passam a compreender melhor por que a Força era tão intensa entre eles.

Apesar do fato de Luke e Léia serem irmãos, a aventura do "resgate da princesa" ocorre em Guerra nas estrelas como nos contos de fadas clássicos ou na mitologia, em que o tradicional triângulo "herói-monstroprincesa" é formado ${ }^{406}$. Mary Henderson, ao analisar essa passagem do Episódio IV, argumenta:

O tradicional triângulo nas antigas estórias de heróis consiste em "herói-monstro-mulher", no qual o herói deve passar pelo monstro para resgatar a dama. Léia, prisioneira de Darth Vader, é agora refém do "dragão" da Estrela da Morte. Compatível com

${ }^{406}$ HENDERSON, M. Op. cit., p. 47. 
uma estória do século $\mathrm{XX}$, o dragão é um monstro high-tech, mas ainda solta fogo e destrói tudo em seu caminho ${ }^{407}$.

Como na mitologia grega, o herói deve penetrar no labirinto, resgatar a princesa e matar o monstro ${ }^{408}$. Em Guerra nas estrelas, Luke invade a Estrela da Morte, resgata a princesa Léia e, a seguir, destrói a arma mortal do Império.

Na terceira parte da trilogia, novamente o episódio de resgate iria se repetir (Figura 19a), sendo que, desta vez, o herói socorre a irmã, que havia sido capturada pelo repugnante Jabba, uma criatura gigantesca e perversa ${ }^{409}$.

Também na saga de Harry Potter há o tema do resgate, apesar de ambos, herói e "princesa", no caso, serem ainda duas crianças. O episódio ocorre no livro 2, em que um basilisco ${ }^{410}$ assombra o castelo de Hogwarts, ameaçando os estudantes.

O embate monstro-herói ocorre quando Gina, irmã mais nova de Rony, é aprisionada na câmara secreta, esconderijo do basilisco ${ }^{411}$ (Figura 19b). Contando com a ajuda de uma espada e de uma fênix, Harry Potter consegue derrotar o monstro e salvar a menina, por quem mais tarde ele iria apaixonar-se $\mathrm{e}^{412}$

407 Idem, ibidem. ["The tradicional triangle in ancient hero stories consists of 'hero-monsterwoman', in which the hero must overcome a monster in order to rescue a maiden. Leia, taken captive by the knight Darth Vader, is now guarded by the 'dragon' of the Death Star. As is suitable for a twentieth-century story, the dragon is a high-tech monster, but it can still breathe fire and destroy everything in its path"].

${ }^{408}$ Como acontece no triângulo Teseu-Minotauro-Ariadne, da mitologia grega (VICTORIA, L. A. P. Dicionário básico de Mitologia. São Paulo, Ediouro, 2000).

${ }^{409}$ Para salvar Han Solo das mãos do sórdido Jabba, Léia é feita sua prisioneira e escrava, porém Luke consegue salvá-la.

410 Uma cobra gigantesca capaz de matar apenas com o olhar.

${ }^{411}$ Por meio de um velho diário enfeitiçado colocado propositalmente entre o material escolar de Gina, Voldemort consegue entrar em Hogwarts manipular as ações da menina, fazendoa cometer atos insanos, como por exemplo abrir a câmara secreta para que o basilisco pudesse sair. No capítulo final da aventura, Voldemort aprisiona Gina na câmara secreta para atrair Harry Potter e colocá-lo frente a frente com seu poderoso monstro, não contando provavelmente com a sorte e a coragem do pequeno herói.

412 No livro 6 da saga, Harry Potter descobre que está apaixonado por Gina e é correspondido. A menina, que já mostrava interesse pelo herói desde o livro 2, passa a ser então sua primeira namorada. 

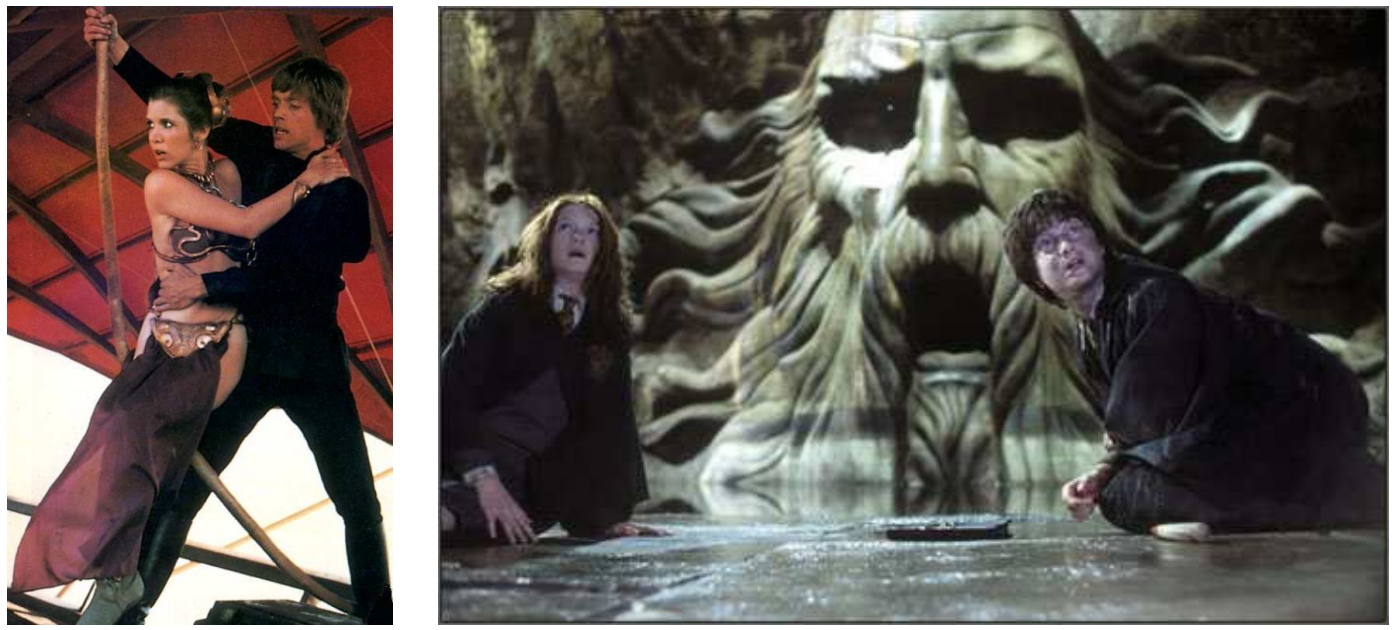

Figura 19 - a) Luke Skywalker resgata mais uma vez a princesa Léia Organa em Episódio VI - $O$ retorno de Jedi, 1983 (à esquerda); b) Harry Potter entra na câmara secreta e enfrenta o basilisco para resgatar Gina, irmã de seu melhor amigo, Rony, em cena do filme Harry Potter e a câmara secreta (2002), baseado no romance homônimo de J. K. Rowling (à direita).

Das nossas três personagens órfãs, talvez Peter Parker seja aquela que mais resgates de "princesas" tem a fazer ao longo de suas inúmeras aventuras, uma vez que faz parte das funções de um super-herói perseguir bandidos e proteger "mocinhas indefesas". No entanto, nos primeiros três episódios de quadrinhos analisados e descritos neste capítulo, a única "missão de resgate" do Homem-Aranha é a de um astronauta, ocorrida na segunda $H Q^{413}$.

Porém outros episódios na longa jornada deste super-herói podem ser lembrados quando o assunto é o triângulo: herói-vilão-mocinha. Peter Parker (ou o Homem-Aranha) demonstra uma especial fraqueza quando inocentes são seqüestrados ou feitos reféns nas ações de bandidos, principalmente nos casos em que, entre esses reféns, estão mulheres indefesas, como suas namoradas ou sua velha tia May. Cientes dessa vulnerabilidade tipicamente

${ }^{413}$ LEE, S. \& DITKO, S. Op. cit., pp. 21-28. Cf. Cap. 3, pp. 159-160. 
humana do herói, essa artimanha sempre que possível é usada pelos vilões para atraí-lo.

Porém o Homem-Aranha não é um super-herói invencível, e nem sempre suas ações têm resultados favoráveis. Um exemplo disso é justamente o episódio de um resgate frustrado, do qual resultou a morte de sua primeira namorada, Gwen Stacy ${ }^{414}$.

Publicada na revista Amazing Spiderman, n.122, em julho de 1973 (Figura 20), a HQ traz um dos vários duelos entre o Homem-Aranha e o Duende Verde. No enredo, o vilão prende Gwen Stacy, então namorada de Peter Parker, no alto da ponte George Washington (Brooklin Bridge, NY), a fim de atrair o Aranha, cuja identidade secreta ele já conhecia. Em meio à luta, o Duende solta a moça do alto da ponte e, na tentativa de resgatá-la, o herói consegue capturá-la no ar com sua teia, mas não evita sua morte, ocorrida devido ao impacto da freada na queda.

Assim como a morte de tio Ben logo na primeira $\mathrm{HQ}$ da série, esse episódio marcaria muito a vida e o destino do super-herói e do jovem Peter Parker, que terá de aprender a lidar com mais essa perda, e, sobretudo, com mais um sentimento de culpa.

Já nas recentes adaptações das $\mathrm{HQ}$ para o cinema, Spiderman (2002) e Spiderman 2 (2004), os triângulos formados por herói-vilão-mocinha são outros: a figura do vilão é representada, respectivamente, por dois inimigos do Aranha nascidos nos quadrinhos, o próprio Duende Verde e o Dr. Octopus, enquanto a mocinha a ser resgatada é a futura esposa de Peter Parker, Mary

\footnotetext{
${ }^{414}$ Muitos consideram esse episódio como um dos mais traumáticos na vida do herói, ao lado do primeiro, em que há a morte do tio Ben. Disponível em < http://www.graphiqbrasil.com /clássicos/ gwenstacy.html> Acesso em 12/12/05. e em < http://www.omelete.com.br /quadrinhos/artigos/base_para_artigos.asp?artigo=774> Acesso em 12/12/05.
} 
Jane Watson (Figura 21), que nos quadrinhos substitui Gwen Stacy como

namorada do herói.

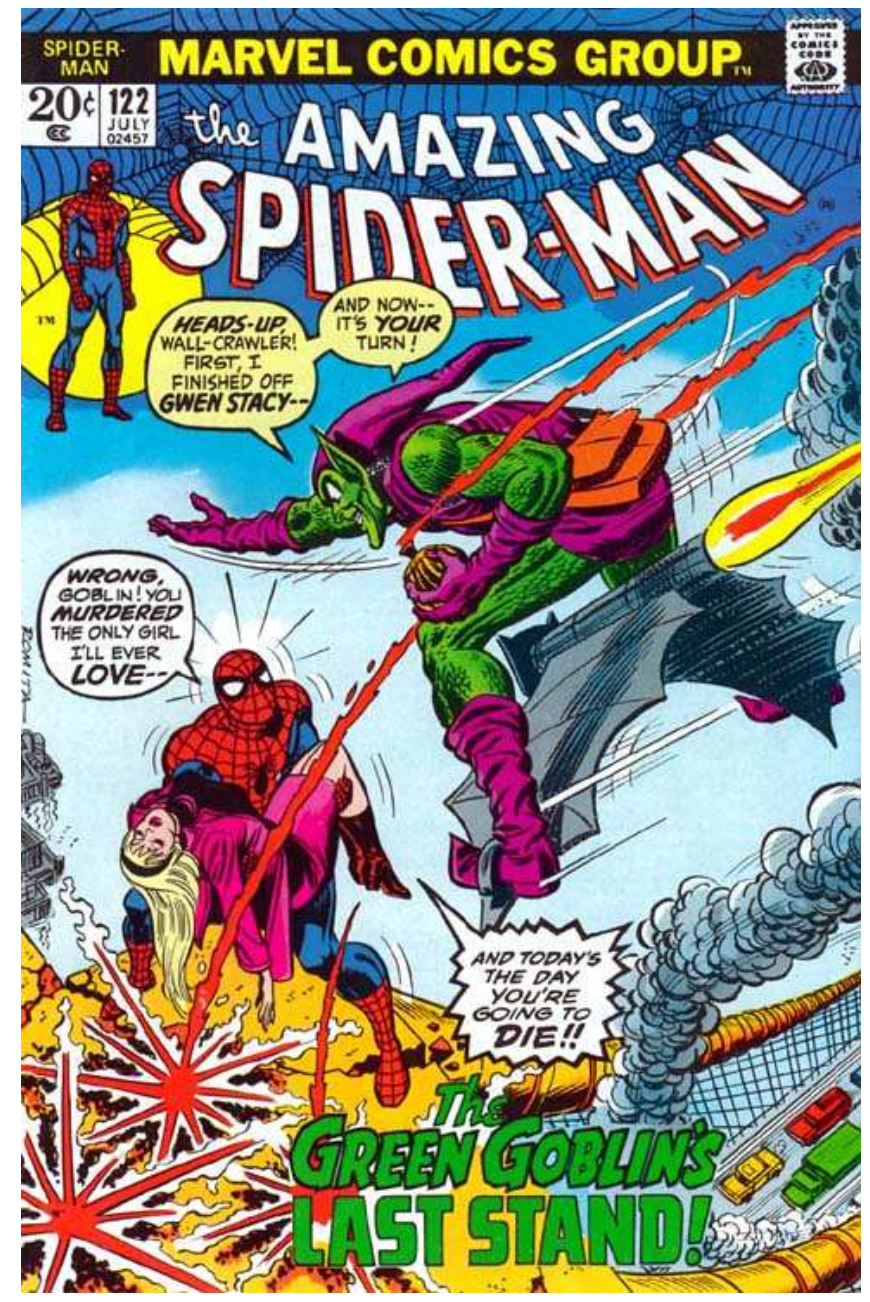

Figura 20 - Capa da revista Amazing Spiderman, n. 122 (1973), em que ocorre a morte de Gwen Stacy, namorada de Peter Parker. Na ilustração o Homem-Aranha carrega a sua amada e promete a morte do vilão, o que de fato acontece ainda na mesma revista.
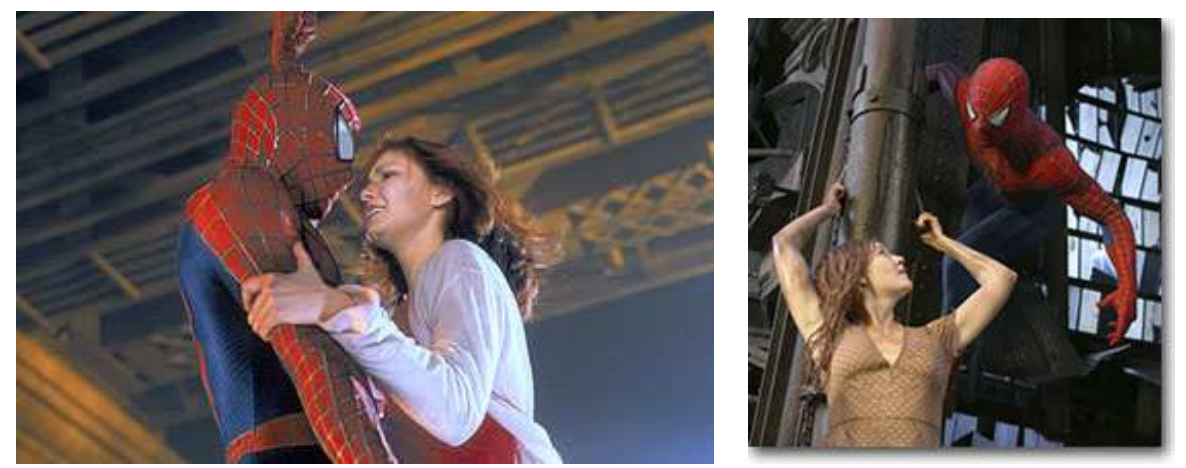

Figura 21 - À esquerda, Homem-Aranha salva Mary Jane, presa na Ponte George Washington pelo Duende Verde em cena que faz alusão ao episódio ocorrido com sua primeira namorada, Gwen, nos quadrinhos (Spiderman, 2002); à direita, Homem-Aranha tenta resgatar Mary Jane das mãos do Dr. Octopus em cena de Spiderman 2 (2004). 
Para finalizar nossa análise sobre o período de iniciação, abordaremos ainda dois aspectos da trajetória do herói: a perda do guia, mentor ou protetor, e o confronto final com o vilão.

Dos três heróis analisados, Peter Parker é o único que não parte acompanhado por um guia ou protetor; por isso mesmo suas "perdas" são de outra natureza, como por exemplo a citada morte de sua namorada.

Já Harry Potter tem como primeiro guia o gigante Hagrid, responsável por lhe entregar o "chamado para a aventura" e por conduzi-lo até o primeiro limiar de sua jornada. Ao entrar no mundo dos bruxos, porém, o herói passa a contar com outros guias e protetores, como alguns professores de Hogwarts e, principalmente, seu diretor, Alvo Dumbledore. A partir do livro 3, quando o bruxo Sirius apresenta-se como padrinho de Harry, essa personagem passa a dividir com Dumbledore a importante função de proteger o pequeno órfão.

No entanto, à medida que o herói cresce e deixa de ser uma criança, aos poucos vão aumentando as dificuldades em sua trajetória, e, para isso, são subtraídas de seu caminho as pessoas com quem ele mais contava: no livro 5, Harry perde o padrinho ${ }^{415}$, que morre em um confronto com Belatriz, uma das seguidoras de Voldemort; no livro 6, é a vez de o jovem bruxo perder Dumbledore ${ }^{416}$, o mais poderoso mago que ele conhecera até então.

Embora a perda de Sirius tenha sido mais dolorosa para o menino, do ponto de vista afetivo, uma vez que o órfão se afeiçoara muito ao padrinho, a

${ }^{415}$ Em um dos capítulos finais do livro 5, Harry Potter, alguns colegas e outros componentes da Ordem da Fênix enfrentam os poderosos "Comensais da Morte", seguidores de Voldemort. Em um dos duelos travados entre membros da Ordem e Comensais, o padrinho de Harry, Sirius Black, é atingido por Belatriz, fiel seguidora de Voldemort, e morre.

${ }^{416}$ Vítima de uma armadilha realizada por Draco Malfoy e por Severo Snape, Dumbledore não resiste aos feitiços do ex-professor de Hogwarts e morre. Harry Potter presencia a cena, mas nada pode fazer por estar enfeitiçado. 
de Dumbledore é mais significativa, pois agora Harry estará totalmente só para o confronto final com o vilão.

Bastante semelhante à morte de Dumbledore para Harry é a perda de Obi-Wan para Luke. Ao final do primeiro episódio da trilogia original, o mestre Jedi sucumbe em um duelo de sabre de luz com Darth Vader. Sem poder contar com seu guia, Luke terá de enfrentar o vilão sozinho, como acontece nos episódios V e VI. Embora Obi-Wan volte a aparecer como "espírito" nos capítulos subseqüentes $^{417}$, orientando Luke em algumas de suas ações, sua ausência física é bastante sentida pelo órfão, que tem de superá-la com sua própria ascensão como herói.

Ainda não sabemos se Dumbledore voltará de alguma forma para ajudar Harry em seu duelo final com o vilão Voldemort, porém essa possibilidade existe, uma vez que, obras da mesma natureza trazem a recorrência do episódio da "ressurreição" do líder ${ }^{418}$.

Com relação ao confronto final entre herói e vilão, é provavelmente o Homem-Aranha aquele que mais duelos tem a fazer, não havendo uma batalha final única.

Para cada antagonista criado, há vários embates importantes para o herói, porém podemos aqui nos limitar a citar dois, significativos em especial pelas conseqüências que trazem: o primeiro ocorre em Amazing Spiderman, n. 90 (1970), no epílogo entre o super-herói e o Dr. Octopus. Nesse último

\footnotetext{
${ }^{417}$ Em um dado momento do duelo entre Obi-Wan e Darth Vader, o mestre Jedi afirma que, mesmo se o vilão o atingisse, ele não morreria. De fato é o que acontece: ao ser tocado pelo sabre de luz de Vader, o corpo de Obi-Wan desaparece e ele volta mais tarde para orientar Luke em uma outra dimensão, como um "fantasma" ou um espírito.

${ }^{418}$ Além de Obi-Wan em Guerra nas estrelas, temos, por exemplo, a volta do mago Gandalf no segundo livro da saga de $O$ Senhor dos Anéis (TOLKIEN, J.R.R.), As duas torres, após sua suposta morte no primeiro livro, $A$ sociedade do Anel; o mesmo ocorre com o líder Aslam no segundo volume de As crônicas de Nárnia, O leão, a feiticeira e o guarda-roupa (LEWIS, C.
} 
confronto, um dos braços mecânicos do vilão cai do alto de um prédio e acaba atingindo mortalmente o Capitão George Stacy, pai de Gwen, então namorada de Peter Parker. No final desse episódio, o Homem-Aranha acaba sendo responsabilizado pela morte do capitão, inclusive pela própria filha, que desconhecia então a dupla identidade de seu namorado. Outro embate que tem conseqüências bastante trágicas para o herói é o já citado duelo final com o Duende Verde, quando este, antes de sucumbir, causa a morte de Gwen, sua amada.

Em Guerra nas estrelas há três confrontos principais, além dos paralelos, ao final de cada um dos filmes: Obi-Wan x Darth Vader, "vencido" por Vader ${ }^{419}$; Luke $x$ Darth Vader, vencido por Vader ${ }^{420}$ e um novo confronto Luke x Darth Vader, vencido por Luke ${ }^{421}$ (Figura 22). Há ainda o confronto final entre Luke e o Imperador, vencido por Luke com a ajuda de Vader, quando o vilão se redime perante o filho.
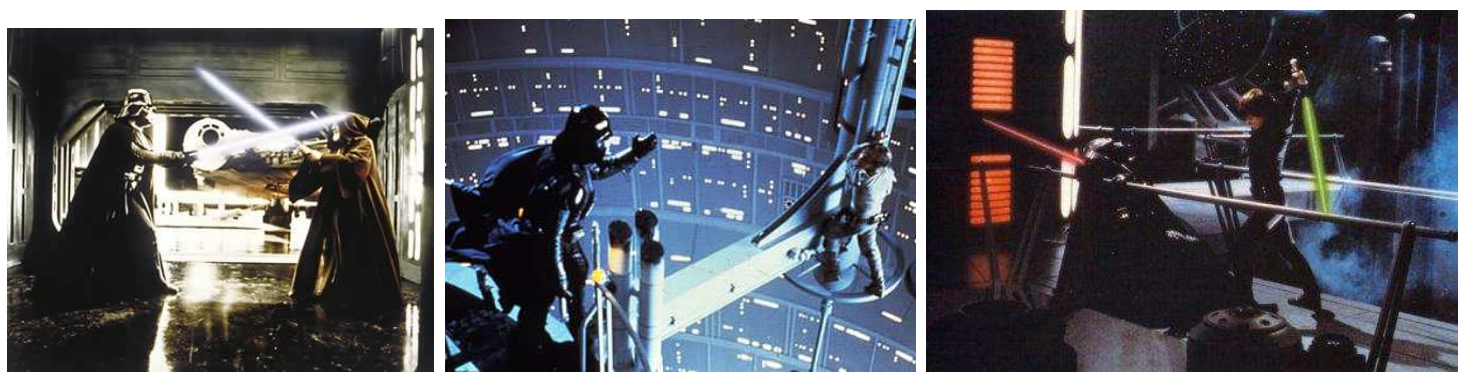

Figura 22 - Três confrontos entre vilão e herói: à esquerda, Darth Vader x Obi-Wan, em Episódio IV; ao centro, Darth Vader $\mathrm{x}$ Luke, em Episódio V, e à direita Darth Vader $\mathrm{x}$ Luke, em Episódio VI.

S.), quando o leão é sacrificado e morto, mas volta como um "imortal", sem qualquer ferida pelo corpo.

419 Episódio IV - Uma nova esperança, 1977. Ao final deste duelo, o corpo de Obi-Wan desaparece e, embora chocado, Luke consegue fugir com seus amigos da Estrela da Morte; a seguir a aliança rebelde consegue destruir a arma mortal do Império, mas Darth Vader escapa.

420 Episódio V - O Império contra-ataca, 1980. No primeiro duelo entre pai e filho, Vader consegue desarmar Luke, cortando sua mão direita. Luke consegue fugir com a ajuda de Léia.

${ }^{421}$ Episódio VI - O retorno de Jedi, 1983. Finalmente Luke consegue derrotar Vader, que se redime. 
Já Harry Potter traz uma série de confrontos entre o herói e o maquiavélico vilão Voldemort, em quase todos os livros da série: no livro 1, Harry enfrenta Quirrel, professor de Hogwarts que portava o espírito de Voldemort; no livro 2, o herói enfrenta o basilisco, que agia sob ordens de Voldemort; no livro 4, há talvez o duelo mais importante entre herói e vilão, quando Harry presencia o renascimento de Voldemort e o enfrenta em um duelo de varinhas sem vencedor; no livro 5, novamente Harry enfrenta Voldemort, mas com a ajuda de Dumbledore consegue escapar mais uma vez. Espera-se que o livro 7 traga o derradeiro confronto entre os dois, e que o herói - como nos melhores contos de fadas - possa sair vitorioso. 


\subsubsection{Retorno}

Gubernatorem in tempestate intellegas; in acie militem.

É na tempestade que se conhece o piloto; na luta que se conhecem os heróis.

(Sêneca)

Segundo Campbell, o último capítulo da saga do herói é marcado por seu retorno ${ }^{422}$. Fazendo o caminho inverso ao da partida, o herói vai-se despindo dos amuletos, auxílios e guias que obteve durante sua jornada para efetuar "a passagem pelo limiar do retorno":

Trata-se da paradoxal e supremamente difícil passagem do herói pelo limiar do retorno, que o leva do reino místico à terra cotidiana. Seja resgatado com ajuda externa, orientado por forças internas ou carinhosamente conduzido pelas divindades orientadoras, o herói tem de penetrar outra vez, trazendo a bênção obtida, na atmosfera há muito esquecida na qual os homens, que não passam de frações, imaginam ser completos. Ele tem de enfrentar a sociedade com seu elixir, que ameaça o ego e redime a vida, e receber o choque do retorno, que vai de queixas razoáveis e duros ressentimentos à atitude de pessoas boas que dificilmente o compreendem ${ }^{423}$.

A figura que cruza esse limiar já não é mais a mesma que partira tempos atrás. Após atravessar o período de iniciação e realizar o caminho de provas, aquele ser frágil e imaturo - que muitas vezes careceu de guia, conselhos e ajuda - volta ao lar com a plenitude e o status de herói, mais apto a guiar do que a ser guiado, a proteger do que a ser protegido.

${ }_{422}$ CAMPBELL, J. Op. cit., 1990, pp. 195-240.

${ }^{423}$ CAMPBELL, J. Op. cit., 2002, p. 213. 
Harry Potter deixa pela primeira vez o lar onde foi criado com 0 pensamento cheio de sonhos e ilusões. Aos onze anos de idade, parte para um mundo desconhecido onde cresceria não apenas em idade, mas em conhecimento, em coragem, em responsabilidade. Ao final do último livro terá quase dezoito anos, e nesses sete anos de percurso terá vivido provavelmente o período mais importante e significativo de sua vida.

Quando é picado pela aranha radioativa, e adquire seus superpoderes, Peter Parker é um adolescente em busca de afirmação. À medida que se desenvolvem as seqüências de $\mathrm{HQ}$, a personagem deixa de ser um estudante sem responsabilidades para tornar-se um jovem trabalhador; deixa de ser um aspirante a super-herói para tornar-se uma realidade. Nas revistas atuais, Peter Parker é um homem casado, que volta à escola onde estudou não mais como um aluno dedicado, mas como um conceituado professor $^{424}$.

A primeira vez que deixa Tatooine seguindo os passos de Obi-Wan Kenobi, Luke Skywalker é um jovem fazendeiro que jamais deixara o planeta desértico onde fora criado. Aos poucos descobre suas virtudes, suas habilidades, seu poder em controlar a Força; aumentam suas responsabilidades. Quando retorna ao seu planeta de infância, Luke não é mais um adolescente; é um Cavaleiro Jedi, e volta em uma missão de resgate. Já não carece de guia nem de proteção. Pelo contrário: ele vem para guiar e para proteger.

Campbell acredita que o regresso do herói - assim como ocorre na partida e na iniciação - é um capítulo marcado por algumas etapas, entre as

${ }^{424}$ Revista Homem-Aranha, n. 48, dezembro de 2005. Publicada no Brasil pela Panini Comics. 
quais: "a recusa do retorno", "o retorno com auxílio externo", "a fuga mágica" e "a passagem pelo limiar de retorno".

Após analisar pontos paralelos e divergentes nas trajetórias de nossos três heróis órfãos, desde a partida até o final do período de iniciação, veremos de que maneira é construída esta última etapa de suas jornadas.

Os livros da série Harry Potter são cíclicos: começam e terminam com o herói no mundo "normal". Do mesmo modo que no início de cada volume o herói parte para Hogwarts, passando pela barreira para o mundo dos bruxos, na Plataforma 91/2, no final ele regressa para casa, cruzando o limiar de retorno.

Ao atravessar o primeiro limiar, no livro 1, Harry mal sabia quem era e o que era capaz de fazer. Seu maior receio era decepcionar aqueles que acreditavam em seu potencial sem ao menos conhecê-lo. Logo nos primeiros minutos após sua chegada ao castelo, o frágil herói demonstrava claramente toda a sua insegurança ao saber que os alunos novos iriam passar por uma espécie de seleção:

O coração de Harry deu um pulo terrível. Um teste? Na frente da escola toda? Mas ele ainda nem conhecia mágica nenhuma que diabo teria que fazer? Não previra nada do gênero assim logo na chegada. (...) Nunca se sentira tão nervoso, nunca... ${ }^{425}$.

Em contrapartida, no final do livro 6, Harry Potter não é mais uma criança de onze anos de idade; é um adolescente maduro, com vivências e responsabilidades próprias de um adulto, e seus medos e receios são muito diferentes daqueles que ele demonstrava ao entrar pela primeira vez em

${ }^{425}$ ROWLING, J. K. Harry Potter e a pedra filosofal, p. 102. 
Hogwarts. Em seu último retorno ${ }^{426}$, o jovem tem apenas um objetivo: prepararse para o confronto final com seu maior inimigo.

Outro aspecto apontado por Campbell e presente por mais de uma vez na obra de J. K. Rowling é a "recusa do retorno"427. O autor analisa essa recusa do herói afirmando que:

O primeiro problema do herói que retorna consiste em aceitar como real, depois de ter passado por uma experiência da visão de completeza, que traz satisfação à alma, as alegrias e tristezas passageiras, as banalidades e ruidosas obscenidades da vida. Por que voltar a um mundo desses? ${ }^{428}$.

Todas as vezes que se vai aproximando do momento de retornar à casa onde vive com os tios, por meio de suas reações, Harry Potter demonstra oposição ao regresso, como é possível notar, por exemplo, nas passagens abaixo, que fazem parte dos capítulos finais dos livros 4 e 5, respectivamente:

O resto da viagem foi bem agradável; Harry na verdade desejou que ela pudesse ter continuado pelo verão afora, e que nunca chegassem à King's Cross... Mas como aprendera a duras penas aquele ano, o tempo não desacelerava quando alguma coisa desagradável estava à espera da gente, e logo, logo o Expresso de Hogwarts estaria entrando na plataforma nove e meia $^{429}$.

Quando o trem começou a diminuir a velocidade, próximo à estação de King's Cross, Harry pensou que nunca tivera tão pouca vontade de desembarcar. Chegou a considerar por um momento o que aconteceria se ele simplesmente se recusasse a sair e insistisse em continuar sentado ali, até o dia primeiro de setembro, quando o trem o levaria de volta a Hogwarts ${ }^{430}$.

${ }^{426}$ O livro 6 é o único da série cujos parágrafos finais não relatam o desembarque dos alunos em King's Cross, mas a idéia de retorno fica clara nos diálogos desenvolvidos neste último capítulo.

${ }^{427}$ CAMPBELL, J. Op. cit., 2002, p. 195.

${ }^{428}$ Idem, p. 215.

${ }^{429}$ ROWLING, J. K. Harry Potter e o cálice de fogo, p. 582.

${ }^{430}$ ROWLING, J. K. Harry Potter e a Ordem da Fênix, p. 699. 
O desejo de Harry de prolongar a viagem (livro 4) ou de permanecer no trem durante todo o verão (livro 5) enfatiza a recusa do retorno à velha rotina que o esperava assim que ele cruzasse o limiar da Plataforma 91/2, desembarcando do Expresso de Hogwarts.

Outra etapa do retorno que aparece em Harry Potter é a "fuga mágica", com exemplos em pelo menos dois dos seis volumes analisados. Um deles é o que ocorre no livro 4, quando, no clímax de sua jornada, antes de retornar para casa após o confronto final com o vilão, o herói consegue escapar de uma armadilha com a ajuda de um objeto mágico, a "Chave do Portal’431:

Ele ouviu o grito de fúria de Voldemort no mesmo instante em que sentiu o solavanco no umbigo que significava que a Chave do Portal fora acionada... ele se afastou em alta velocidade num turbilhão de vento e cor, levando Cedrico junto... os dois estavam voltando... ${ }^{432}$

No livro 6, após participarem de uma difícil etapa para resgatar um objeto mágico, Harry Potter e o mestre Dumbledore são obrigados a fugir o mais rápido possível do lugar onde estavam, para que o mago pudesse tomar um antídoto para a poção envenenada que havia ingerido. Nesse episódio, ocorre uma curiosa inversão de papéis: Harry Potter, antes o protegido e guiado por seu mestre, passa a protegê-lo e guiá-lo durante a "fuga mágica":

"Não fale agora", disse Harry, (...) "Economize sua energia, Senhor... Logo estaremos fora daqui"... (...) "Tudo vai ficar bem, Senhor", Harry disse outra e outra vez, mais preocupado com o silêncio de Dumbledore do que com a fraqueza em sua voz. "Estamos quase lá... Eu posso nos aparatar de volta... Não se preocupe..."

${ }^{431}$ No original, Portkey. Nos livros de Rowling, a "Chave do Portal" é um objeto comum previamente enfeitiçado com o objetivo de transportar uma pessoa de um lugar para outro pré-determinado.

${ }^{432}$ ROWLING, J. K. Harry Potter e o cálice de fogo, p. 532. 
"Eu não estou preocupado Harry", disse Dumbledore, sua voz um pouquinho mais forte, apesar da água gelada. "Eu estou com você", $^{, 33}$.

Embora Harry Potter tenha conseguido trazer Dumbledore de volta, seu esforço não é suficiente para evitar a morte do mestre, em uma armadilha preparada por seguidores de Voldemort.

A perda de seu mais precioso guia nesse momento de sua trajetória confere a Harry, no entanto, o estímulo que Ihe faltava para o confronto final com seu inimigo, que ocorrerá provavelmente apenas no final do livro 7,0 último da saga, quando teremos ciência dos fatos que comporão o derradeiro retorno do herói.

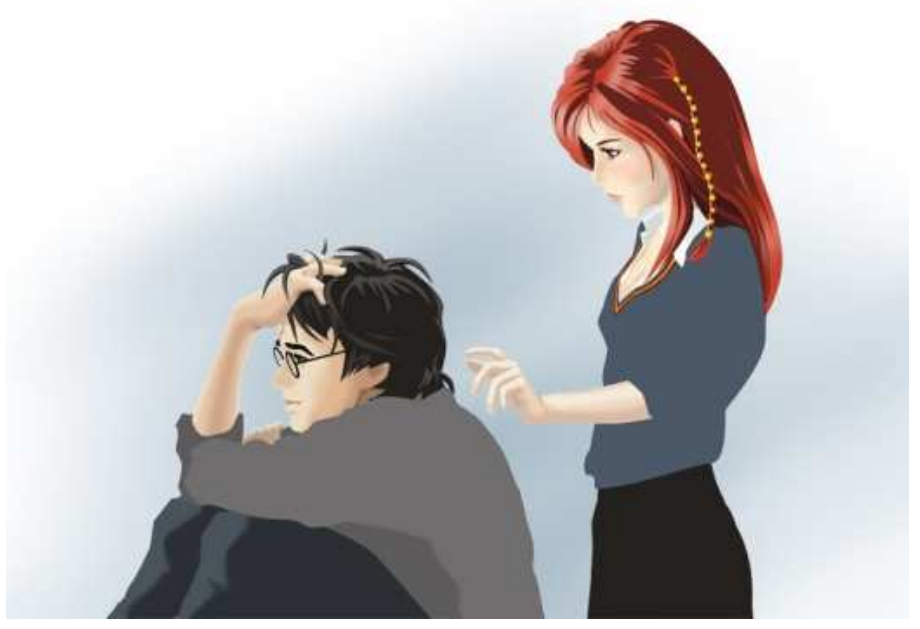

Figura 23 - llustração para Harry Potter e o enigma do príncipe, em que o herói é consolado por sua namorada Gina após a perda do grande mestre e amigo Dumbledore. A recusa do retorno é bastante recorrente em toda a saga, uma vez que, ao final de cada livro, Harry deve voltar ao mundo real para passar as férias de verão com os tios.

${ }^{433}$ ROWLING, J. K. Harry Potter and the half-blood prince, p. 578. ["Don't talk now", said Harry (...) "Save your energy, sir... We'll soon be out of here..." (...) "It's going to be all right, sir" Harry said over and over again, more worried by Dumbledore's silence than the had been by his weakened voice. "We are neraly there... I can Apparate us both back... Don't worry..." "I am not worried, Harry", said Dumbledore, his voice a little stronger despite the freezing water. "I am with you".] 
Também em Guerra nas estrelas é possível analisar algumas características recorrentes quanto ao retorno do herói e suas aventuras mais significativas.

No Episódio IV, por exemplo, há a recusa do retorno por parte do herói, após o resgate da princesa. Na cena em questão, vendo seu mestre em perigo, Luke nega-se a embarcar na nave Falcon para regressar, insistindo em permanecer a bordo da Estela da Morte para ajudar Obi-Wan. Pressentindo uma ação repentina do jovem, que provavelmente viria ao seu encontro para tentar salvá-lo, o velho mestre Jedi deixa-se abater por Darth Vader, desobrigando o herói de uma arriscada missão e "permitindo" sua fuga.

É interessante notar, no percurso de Luke durante o primeiro Episódio, que tanto sua partida como seu retorno são motivados por uma situação de perda ou morte: no início do filme, quando é convidado por ObiWan para acompanhá-lo no resgate de Léia, o jovem somente aceita o chamado para a aventura após perder tios assassinados e ter seu lar destruído; no final do filme, Luke recusa-se a retornar sem seu mestre, porém não Ihe resta alternativa quando ele percebe que Obi-Wan sacrificou-se para protegê-lo.

Uma outra característica do retorno do herói citada por Campbell e presente em Guerra nas estrelas é o "retorno com auxílio externo".

Um bom exemplo é a seqüência de fatos que ocorre no final do Episódio V, quando Luke, derrotado por Vader, ferido, desarmado e sem meios para escapar, é socorrido por Léia e somente consegue retornar graças à ajuda de sua irmã. 
Como em Harry Potter, também em Guerra nas estrelas o espectador acompanha o crescimento e o desenvolvimento do herói ao longo dos três episódios que compõem a trilogia original (Figura 24).

Mary Henderson, ao analisar o perfil da personagem, afirma:

Luke é uma personagem comum que atinge a estatura de herói; seu inimigo supremo é um destruidor que almeja devorar tudo, e sua maldade está direcionada pessoal e especificamente para acabar com o próprio herói. No final, o herói deve enfrentar esse monstro sozinho, em um confronto fora do controle das forças organizadas do bem ${ }^{434}$.

Ou seja, para atingir a "estatura" de herói, Luke deve "enfrentar o monstro sozinho", e para isso tem de crescer e abrir mão de seus sonhos e seu modo simples de ser; deve transformar o pacato adolescente aprendiz de fazendeiro em um poderoso Cavaleiro Jedi, o “escolhido” para salvar a Galáxia.
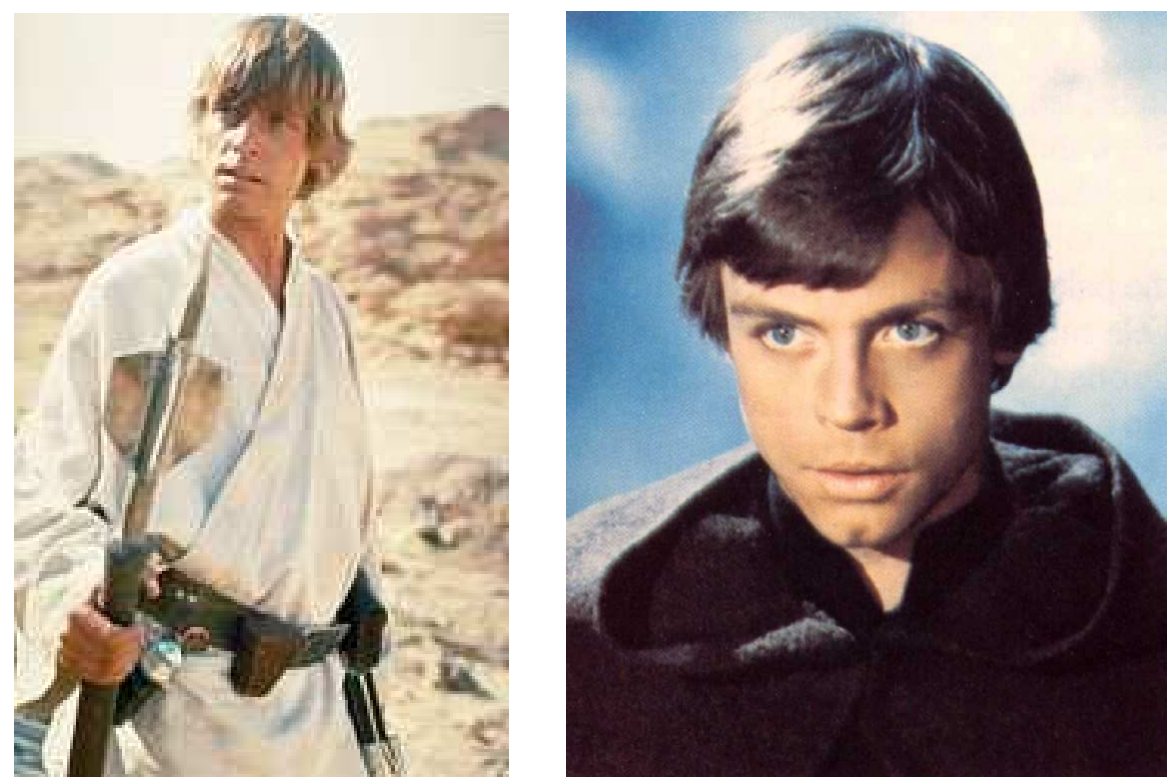

Figura 24 - À esquerda, o herói Luke Skywalker antes de iniciar sua jornada (Episódio IV) e, à direita, já como Cavaleiro Jedi (Episódio VI). A mudança em seu figurino (do branco para o negro) contribui para a caracterização do crescimento interior do herói, em sabedoria e em domínio das próprias emoções.

${ }^{434}$ HENDERSON, M. Op. cit., p. 198. Texto original em inglês: "Luke is an ordinary character who grows to heroic stature; the supreme enemy is a destroyer who would devour all, and his malice is directed personally and specifically at the hero himself. Ultimately, the hero must face this monster alone, in a confrontation that takes place outside the organized forces for good". 
No final do último episódio, Luke é, sem dúvida, um herói bastante diferente daquele que partiu de Tatooine com Obi-Wan na nave Falcon, ultrapassando as fronteiras de seu primeiro limiar. Após arriscar a vida em diversas missões e enfrentar perdas significativas em seu caminho, como a morte de seus mestres Obi-Wan e Yoda, antes de seu retorno Luke tem de conformar-se com sua real orfandade, ao presenciar o definhamento e a morte do pai, que em seus últimos minutos de vida conquista o amor do filho.

Em seu derradeiro retorno - não por acaso em um episódio intitulado "O retorno de Jedi" -, Luke traz em seus braços o corpo já sem vida do vilão Darth Vader, a fim de proporcionar-Ihe um funeral.

Talvez para o herói, a mais importante conquista em toda a sua jornada não tenha sido a derrota do Império ou a volta da democracia na Galáxia, mas a redenção de seu pai, que possibilitou o reencontro de Anakin Skywalker com os extintos Cavaleiros Jedi, em uma outra dimensão (Figura 25).

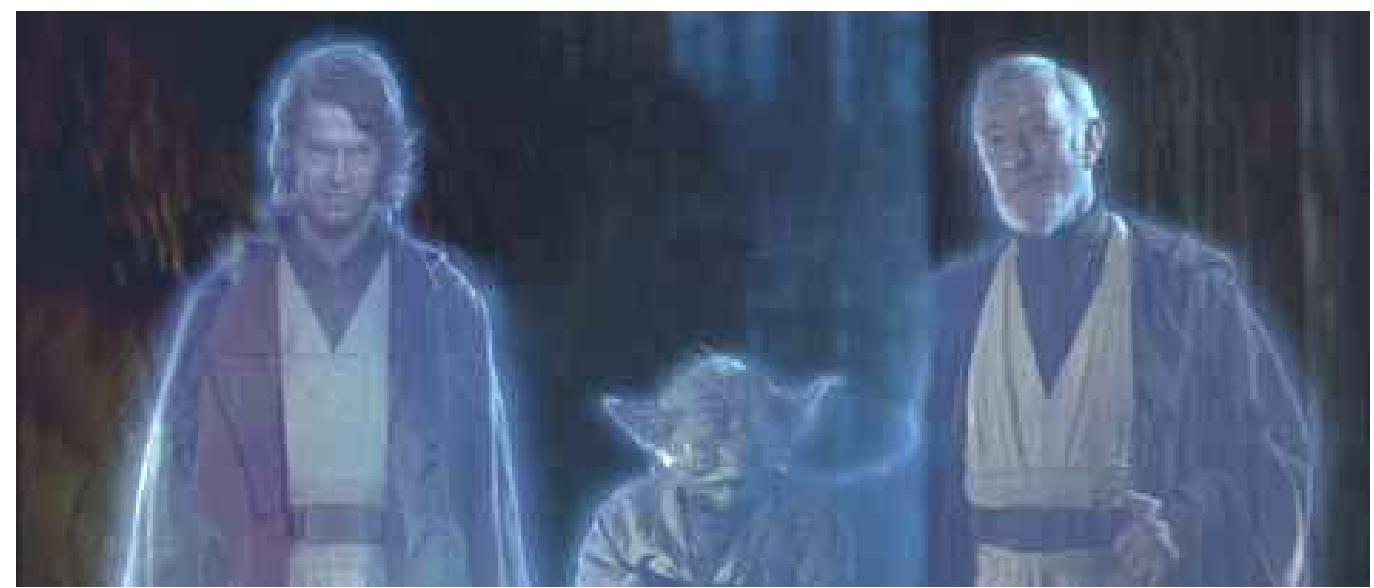

Figura 25 - Após a morte e redenção de Darth Vader, Anakin Skywalker, pai de Luke, junta-se aos velhos cavaleiros Jedi - Yoda e Obi-Wan Kenobi - em uma outra dimensão (Episódio VI - $O$ retorno de Jedi). 
Assim como Harry Potter e Luke Skywalker, também Peter Parker desenvolve-se e cresce como herói no decorrer das HQ que lhe servem de suporte. O adolescente fraco e inexperiente dos primeiros quadrinhos publicados em Amazing Fantasy no início da década de 1960 nada tem de semelhante com o homem forte e robusto em que o herói se transformou ao longo dos anos (Figura 26).
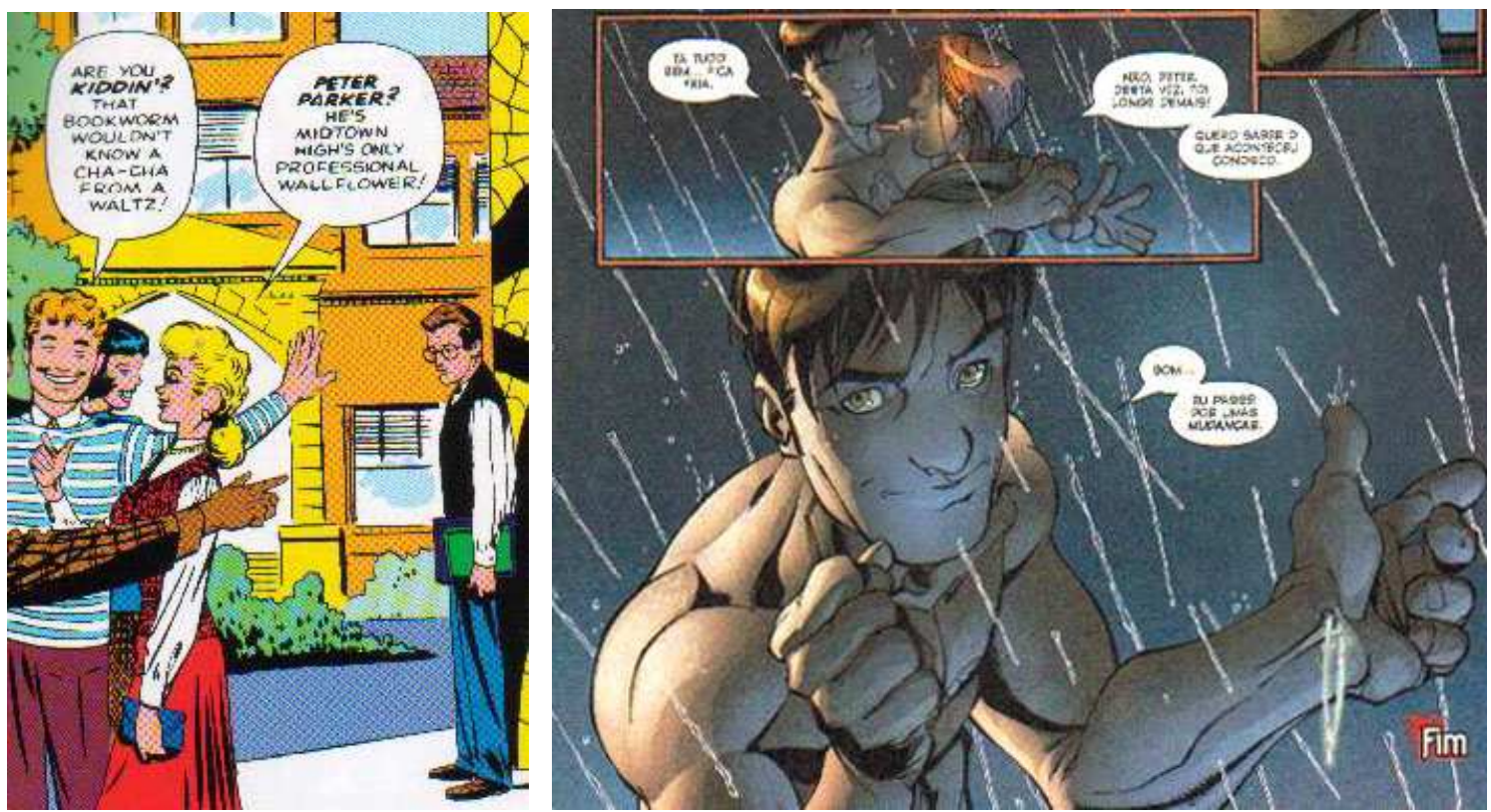

Figura 26 - À esquerda, o primeiro quadrinho de "Spider-Man!", HQ original publicada em agosto de 1962 na revista Amazing Fantasy, em que o jovem Peter Parker é alvo de gozações de seus colegas; à direita, a cena final do episódio "Transformações" (Parte IV, publicado na revista mensal Homem-Aranha, Panini Comics, dezembro de 2005, p.49) No último quadrinho a fala do herói é: "Bom... Eu passei por umas mudanças".

No entanto não é apenas fisicamente que o herói aparenta mudanças.

Embora continue sempre renovando o sentimento de culpa que carrega pela morte de seu tio Ben e de sua antiga namorada Gwen, e ainda pelos constantes seqüestros e ameaças de morte de sua tia May e de sua esposa, Mary Jane, Peter Parker demonstra uma maior maturidade para lidar com essas questões. 
Apesar das transformações ocorridas na personagem decorrentes de seu próprio crescimento físico e emocional, e também no que se refere ao refinamento da técnica utilizada para a confecção das HQ modernas, o herói mantém características constantes e atitudes coerentes, nesses quarenta e quatro anos de existência.

Assim como não tem um autêntico "chamado para a aventura", Peter Parker também não protagoniza um retorno derradeiro, uma vez que não há um enredo "fechado" para a personagem e suas aventuras não seguem necessariamente uma ordem cronológica precisa.

As revistas atuais, por exemplo, são compostas por quatro ou cinco episódios de $\mathrm{HQ}$ diferentes, não havendo qualquer relação entre elas ${ }^{435}$. No entanto, é possível perceber algumas recorrências no que concerne ao aqui denominado "retorno" do herói.

Desde sua primeira aparição nos quadrinhos - e diferentemente de outros super-heróis como Batman ou Super-Homem -, Peter Parker demonstra fragilidade e seu retorno após uma aventura é muitas vezes marcado por um "fracasso", mesmo quando tenha "vencido" um inimigo ou realizado alguma proeza.

Bons exemplos desses retornos são os episódios já citados da morte do Capitão Stacy (Figura 27) e de sua filha, Gwen, que ocorrem respectivamente após os duelos com o Dr. Octopus e o Duende Verde, ambos "vencidos" pelo Aranha ${ }^{436}$.

${ }^{435}$ Por exemplo, na revista Homem-Aranha, n. 48, publicada em dezembro de 2005 pela Panini Comics, há quatro episódios incompletos, pertencentes a quatro HQ diferentes: "Herói da Resistência" (parte II de IV); "Transformações" (parte IV de IV); "Reviravolta" (parte II de V) e "À flor da pele" (parte I de IV).

${ }^{436}$ Cf. Cap. 3 pp. 209-213. 


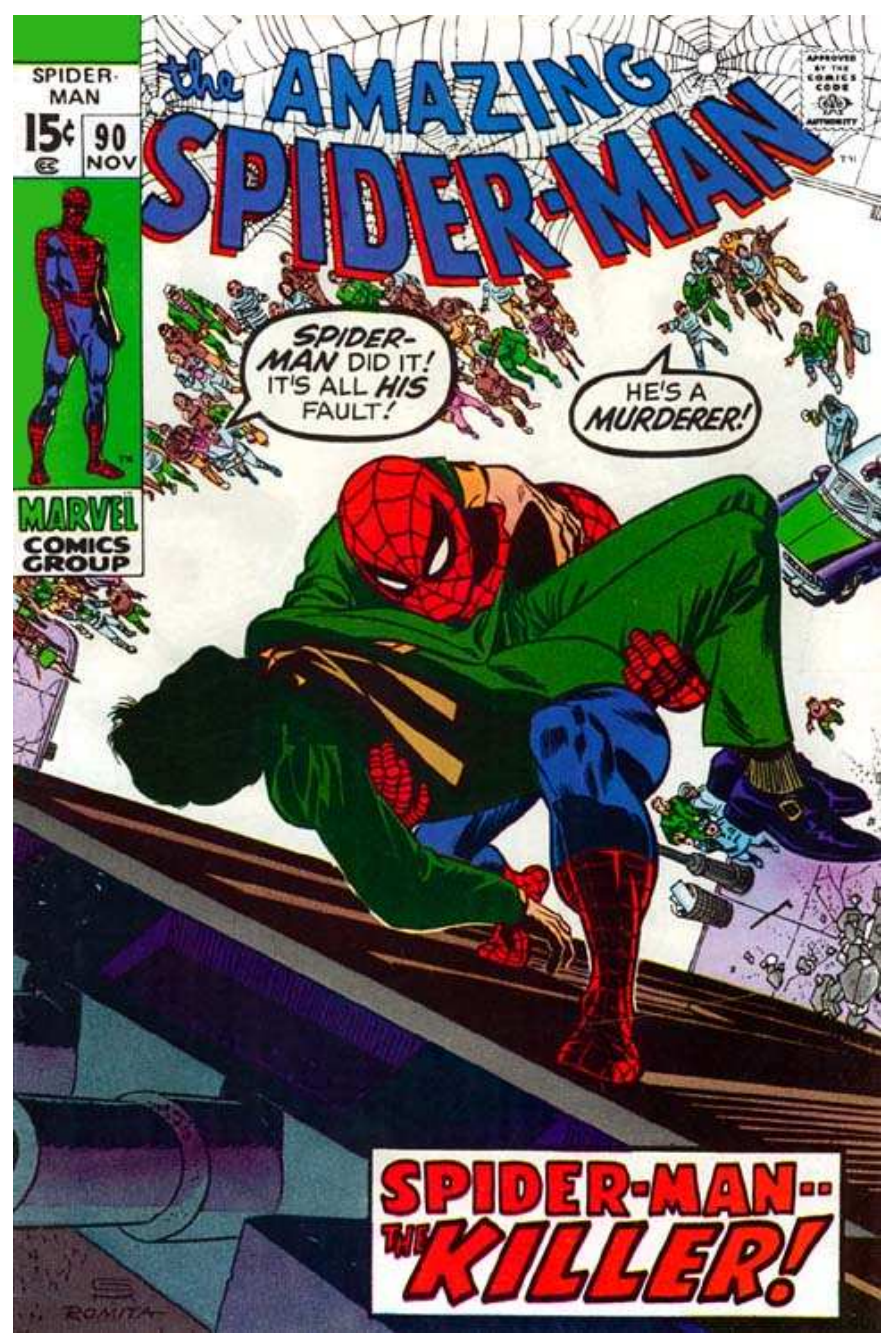

Figura 27 - Capa da revista Amazing Spiderman, n. 90 (1970), em que o herói, após ter vencido o duelo contra o Dr. Octopus, é responsabilizado pela morte do Capitão Stacy, atingido por um dos braços mecânicos do vilão que se desprende durante a luta.

Outros retornos frustrados do herói podem ser encontrados logo nas primeiras HQ publicadas.

$\mathrm{Na}$ aventura original, por exemplo, o retorno do herói para casa é desolador: mesmo após a captura do assassino do tio, Peter Parker não se conforma por ter permitido a fuga do bandido dias antes, fato que poderia ter evitado a morte de Ben. O último quadrinho retrata a figura do jovem solitário cabisbaixo em seu primeiro retorno ${ }^{437}$.

${ }^{437}$ Cf. Fig. 5, p. 159. 
No segundo episódio de que participa, intitulado "Spider-Man Freak! Public Menace!', o herói é acusado por um jornal sensacionalista de ser uma ameaça à população. Mesmo após ter conseguido salvar o filho do editor-chefe do jornal, continua a ser perseguido e é tratado por muitos como inimigo e antiherói. Em seu segundo retorno para casa, Peter Parker sofre ainda ao perceber que terá de enfrentar muito mais do que vilões para convencer o povo a respeito de suas boas intenções, uma vez que vê sua própria tia dar crédito às calúnias publicadas no jornal.

$\mathrm{Na}$ terceira $\mathrm{HQ}$ da série, Peter Parker enfrenta seu primeiro antagonista, o "Camaleão". Após uma série de acontecimentos, novamente o herói encontra problemas ao retornar para casa, sendo confundido com o bandido por policiais e tendo de fugir para não ser capturado por engano.

Outros inúmeros exemplos poderiam ser citados, porém é importante ressaltar que, uma vez que os quadrinhos são por natureza "narrativas seriadas", o retorno de um episódio muitas vezes é construído propositalmente para induzir uma nova partida.

Em Homem-Aranha, no entanto, cada vez que Peter Parker se despe das vestes de super-herói e volta a ser o "pacato" adolescente, independentemente de esse fato situar-se no início, no meio ou no fim de uma $H Q$, há a passagem do herói pelo limiar de retorno, completando-se o ciclo daquela aventura. Diferentemente do que ocorre para Harry Potter e Luke Skywalker, o retorno de Peter Parker é apenas um passo à frente, para que uma nova aventura seja iniciada. 
CONSIDERAÇÕES FINAIS 
O órfão é livre como não podem ser aqueles que vivem com suas famílias.

(Eileen Simpson) $^{438}$

Três foram os principais propósitos que motivaram o desenvolvimento desta pesquisa: 1) investigar a recorrência do tema - o órfão como personagem de ficção -, tendo como ponto de partida as narrativas provenientes da oralidade; 2) estabelecer paralelos e divergências entre as figuras secundárias que cruzam de forma sistemática o caminho do órfão nessas narrativas; e, por fim, 3) analisar comparativamente o percurso de três personagens órfãs contemporâneas, oriundas inicialmente de três diferentes mídias (literatura, quadrinhos e cinema), em três momentos de suas trajetórias: partida, iniciação e retorno.

Sendo assim, o texto principal da presente dissertação foi dividido em três capítulos centrais, cada um deles visando atender a uma das metas propostas.

$\overline{438}$ SIMPSON, E. Op. cit., p. 216. ["The orphan is free in the way those living with their families cannot be"]. 
No primeiro capítulo foi realizado um breve retrospecto sobre conto popular e conto de fadas, por se acreditar que esse vasto e fecundo repertório proveniente da oralidade constitui a "célula-mater" ${ }^{\prime 39}$ da literatura infantil e juvenil.

Tomando como exemplo dez diferentes contos populares ${ }^{440}$ que trazem órfãos como protagonistas, foi possível constatar, sobretudo no que concerne à primeira etapa da jornada do herói, que: 1) a orfandade muitas vezes é o fator que impulsiona o herói a partir em busca de novos objetivos de vida, ou ainda, 2) que a morte dos pais torna o ambiente do órfão insustentável, facilitando ou forçando sua partida ${ }^{441}$.

É possível perceber que essas mesmas fórmulas são utilizadas em inúmeros outros contos populares e contos de fadas, sendo mais comum, na primeira hipótese, o protagonista ser um rapaz, e, na segunda, uma moça. Em ambos os casos, porém, a orfandade é a condição primordial que "permite" ao herói sua saída de casa, legitimando sua partida.

Eileen Simpson, em citação reproduzida no terceiro capítulo desta dissertação, afirma que "um menino sem pais é um protagonista ideal para uma estória de aventura"442. Ao analisarmos os contos populares e contos de fadas sob esse mesmo ponto de vista, podemos concordar que toda "estória de aventura" deveria ser protagonizada por um herói solitário, pois ao mesmo tempo em que a orfandade e o luto consistem em doloroso fardo para o órfão, também lhe concedem a liberdade e o desprendimento necessários para que

\footnotetext{
${ }^{439}$ Expressão utilizada por COELHO, N. N. Op. cit., 1998, p.12.

440 Selecionamos dez contos provenientes de diferentes fontes, dentre os quais procuramos privilegiar o repertório da literatura oral em língua portuguesa.

${ }^{441}$ C.f. Cap. 1, p. 43.

${ }^{442}$ SIMPSON, E. Op. cit., p. 216. ["a boy without parents is an ideal protagonist for an adventure story"] C.f. Cap. 3, p. 126.
} 
ele possa reafirmar-se no mundo que o cerca, e consagrar-se como herói.

Porém, em sua jornada, o órfão raramente está só. Devido ao grande número de personagens secundárias recorrentes que permeiam o caminho do herói, no segundo capítulo desta dissertação, procuramos nos afastar do protagonista para nos aproximarmos dessas figuras que ora ajudam, ora desviam o órfão de seus propósitos. É o caso, por exemplo, das madrastas, das madrinhas, dos irmãos, dos amigos, dos interesseiros, dos seres mágicos, entre tantas outras personagens que classificamos ora como "desvios", ora como "atalhos" no caminho do herói, pelo fato de alterarem seu destino e colaborarem para tornar sua jornada mais árdua ou mais aprazível, dependendo de seu papel na trama.

Dentre as personagens rotuladas como "desvios", sem dúvida uma das figuras mais recorrentes é a da madrasta, que ganhou papel de destaque em diversos contos populares e contos de fadas como antagonista e principal responsável pelas contristações do herói, sobretudo da heroína órfã. Outras figuras secundárias importantes que analisamos como "desvios" foram os irmãos ciumentos e os amigos interesseiros, que muitas vezes levam o órfão para bem longe de seus objetivos, sendo necessários vários "atalhos" para que ele retome a direção de seus passos.

Classificamos, então, como "atalhos" as personagens que ajudam de certa forma o órfão em seu caminho. Alguns exemplos podem ser encontrados nas madrinhas (ou "fadas-madrinhas"), nos amigos fiéis e nos seres mágicos que cruzam o caminho do herói para facilitar sua empreitada, tornando mais leve seu fardo; mais curta a distância a seguir; mais viáveis as provas a que é submetido; enfim, tornando sua jornada menos solitária. 
No terceiro capítulo desta dissertação, propusemo-nos a analisar três personagens órfãs contemporâneas, concebidas para três diferentes mídias literatura, quadrinhos e cinema -, mas cujo trânsito para outros suportes ocorreu logo depois de seu primeiro surgimento na mídia original.

Antes disso, porém, foi realizado um breve histórico sobre a presença do órfão em cada uma das três mídias analisadas. A partir desse retrospecto, situamos as personagens escolhidas nas obras que lhe serviram primeiramente de suporte - da literatura tomamos o bruxo Harry Potter (Harry Potter and the philosopher's stone, 1997); dos quadrinhos, o adolescente Peter Parker, mais conhecido como "Homem-Aranha" (Amazing Fantasy, 1962), e do cinema o jovem Jedi Luke Skywalker, da primeira trilogia de Guerra nas estrelas (Star Wars, 1977) - e acompanhamos sua trajetória nas três partes que compõem a jornada do herói, segundo Joseph Campbell: partida, iniciação e retorno.

Durante o percurso que fizemos neste terceiro capítulo, não foi difícil perceber que, seja nos contos de fadas, na literatura infantil ou na literatura mundial para adultos e jovens, ou ainda em outras mídias, como os quadrinhos e o cinema, os heróis solitários sempre tiveram seu espaço.

$\mathrm{Na}$ mídia escrita, a literatura inglesa é uma das mais profusas em romances e contos cujos protagonistas são órfãos, especialmente no período situado entre o final do século XIX e o início do século XX. Ao analisarmos alguns autores e obras, foi interessante notar que muitos escritores que se destacaram na concepção de conhecidas personagens órfãs, como Charles Dickens e Charlotte Brontë, por exemplo, traziam a orfandade em sua própria história de vida, fato que, de uma forma ou de outra, pode ter influenciado sua criatividade na composição de seus protagonistas. 
Um exemplo disso é a recente entrevista concedida ao periódico britânico The Daily Telegraph ${ }^{443}$ pela autora J. K. Rowling, na qual ela afirma que a morte de sua própria mãe foi um fato determinante para a caracterização da orfandade da personagem Harry Potter.

Com relação aos quadrinhos, a recorrência da figura solitária é ainda mais evidente. Para ilustrar esta dissertação tomamos para estudo alguns super-heróis criados ao longo do século XX, precursores das HQ de aventura, não ignorando, porém, que o suporte contém inúmeras outras possibilidades de análise, como as personagens Disney, por exemplo. A partir do corpus estabelecido, não foi difícil constatar que os principais super-heróis são órfãos, por vezes duplamente órfãos, como o Super-Homem e o Homem-Aranha, que perdem seus pais verdadeiros e os adotivos no decorrer de suas jornadas. Outros vários super-heróis órfãos foram elencados nesse retrospecto, como Hulk, Fantasma, Batman e Robin, o Demolidor, entre outros. Essa recorrência pode ser explicada pela mesma citação de Eileen Simpson com relação aos heróis da literatura: "O órfão é livre como não podem ser aqueles que vivem com suas famílias" 444 .

Para Loeb \& Morris, um dos fatores que aproxima os super-heróis de seu público, tendo oferecido sobrevida a essas personagens durante várias décadas é a maneira como alguns sentimentos difíceis de serem tratados, a exemplo do medo, da insegurança e da solidão, aparecem nessas narrativas $^{445}$. Porém são esses mesmos sentimentos que, muitas vezes,

\footnotetext{
${ }^{443}$ Entrevista concedida em 10/01/2006. Disponível em <http://www.telegraph.co.uk/news/main. jhtml?xml=/news/2006/01/10/nrowl10.xml. Acesso em 11/01/2006.

${ }^{444}$ SIMPSON, E. Op. cit., p. 216. ["The orphan is free in the way those living with their families cannot be"]

445 LOEB, J. \& MORRIS, T. "Heróis e Super-heróis" in: MORRIS, M. \& MORRIS, T. Op. cit., p. 28.
} 
movem o jovem que existe por trás da máscara a agir em defesa da humanidade, buscando talvez, por meio dessa atitude, superar suas próprias frustrações.

Dos três suportes analisados, talvez o cinema seja atualmente o mais utilizado para a propagação de heróis órfãos, uma vez que mescla adaptações de romances ou $\mathrm{HQ}$ conhecidas, que já trazem essas personagens como protagonistas, com roteiros concebidos originalmente para essa mídia.

Assim, a partir da década de 1930, quando as primeiras animações ganharam as grandes telas, os longas-metragens para cinema têm revivido a saga do órfão em diversas criações originais e recriações de narrativas conhecidas, desde aquelas provenientes dos contos de fadas e dos clássicos infantis, como Branca de Neve, Cinderela e Pinóquio, até as oriundas das mais recentes produções, como Procurando Nemo, Lilo \& Stitch e Chicken Little, entre outras ${ }^{446}$

Além das animações, o cinema tem sido suporte para inúmeras adaptações de romances e $\mathrm{HQ}$, e para roteiros originais criados especialmente para essa mídia, como por exemplo as duas trilogias de Guerra nas estrelas, que contêm duas sagas distintas cujos protagonistas são órfãos ${ }^{447}$.

Embora tendo como aliados os modernos recursos da tecnologia digital, muitas vezes as salas de cinema nos remetem a um tempo em que grupos de pessoas se reuniam ao redor do fogo para ouvir as aventuras de um herói, possivelmente de um herói órfão, que saíra pelo mundo à procura de seu espaço.

\footnotetext{
${ }^{446}$ Cf. Cap. 3, pp. 165-166.

${ }^{447}$ Cf. Cap. 3, p. 176.
} 
Segundo Nelly Novaes Coelho, "vivemos num limiar histórico: em nossos tempos, uma nova era está em gestação. Daí o aparente caos reinante: a ordem racional e progressista defronta-se com a ordem mágico-poética"448. A autora vai além, afirmando que:

\begin{abstract}
Mesmo os "distraídos", se quiserem, podem perceber facilmente que uma das características mais significativas do nosso século é a coexistência, pacífica ou não, entre a inteligência racional/ cientificista, altamente desenvolvida, e o pensamento mágico que dinamiza o imaginário. Isso porque (...) a primeira, representante da lógica tradicional herdada, é desafiada pela nova lógica, seja cibernética (descoberta pela Ciência), seja mágico-poética (inventada pela Arte), que tenta reencontrar as fontes originais da vida e da humanidade através dos escombros daquela racionalidade, que foi brilhante e hoje está esclerosada ${ }^{449}$.
\end{abstract}

Um pouco adiante, a autora ainda acrescenta que: "o maravilhoso, o onírico, o fantástico... deixaram de ser vistos como pura fantasia ou mentira, para ser tratados como portas que se abrem para determinadas verdades humanas" ${ }^{\prime 450}$.

Talvez por isso a jornada do herói permaneça entre os temas mais fascinantes de todos os tempos, independentemente do suporte que a conduza.

Joseph Campbell afirma que "seja o herói ridículo ou sublime, grego ou bárbaro, gentio ou judeu, sua jornada sofre poucas variações no plano essencial” $^{451}$. E complementa:

Os contos populares representam a ação heróica do ponto de vista físico; as religiões mais elevadas a apresentam do ponto de vista moral. Não obstante serão encontradas variações surpreendentemente pequenas na morfologia da aventura, nos papéis envolvidos, nas vitórias obtidas ${ }^{452}$.

\footnotetext{
${ }^{448}$ COELHO, N. N. Op. cit., 1998, p. 7

449 Idem, ibidem.

450 Idem, p. 9.

${ }^{451}$ CAMPBELL, J. Op. cit., 2002, p. 42.

452 Idem, ibidem.
} 
Tomando como base essa premissa, o autor propõe a análise de três episódios capitais da trajetória do herói: partida, iniciação e retorno. Analogamente a esse percurso, assim também dividimos a presente dissertação, reconstruindo nos capítulos centrais três momentos da jornada do órfão: no primeiro capítulo - o começo, ou a partida -, buscamos resgatar as origens da literatura infantil, o órfão e suas raízes, o arquétipo que serviu de modelo e inspiração para tantos outros heróis; no segundo capítulo, o meio, os percalços, os desvios e atalhos desse caminho a ser percorrido; a iniciação do herói e suas transformações; suas lutas, seu crescimento, seu triunfo; no terceiro capítulo, o derradeiro, o fim que é também um recomeço; um capítulo igualmente dividido em três - três personagens, três mídias, três enfoques diferentes -, porém todos com alguma coisa em comum, como se o mesmo herói portasse diferentes vestimentas, disfarces ou amuletos, ora com capa e espada, ora com poderes e máscaras, ora com varinhas e objetos mágicos. Como um retorno às origens, fechando-se um ciclo. Concluímos, pois, esta dissertação com os dizeres de Ovídio:

Tudo está em mudança; nada morre. O espírito vagueia, ora está aqui, ora ali, e ocupa o recipiente que lhe agradar (...) Pois o que existiu já não é, e o que não existiu começou a ser; e assim todo ciclo de movimento se reinicia ${ }^{453}$.

${ }^{453}$ OVIDIO, As metamorfoses. Livro XV APUD CAMPBELL, J. Op. cit., 2002, p. 35. 
BIBLIOGRAFIA 
Almeida, Manuel Antonio De. Memórias de um sargento de milícias. São Paulo, Klick, 1997.

AMADO, JoRge. Capitães da Areia, 45. ed., Rio de Janeiro, Record, 1978.

ANDERSEN, HANS CHRISTIAN. The complete fairy tales. Londres, Wordworth, 1997. "O patinho feio" IN: Estórias Maravilhosas. Adapt. Arnaldo de Oliveira Barreto. São Paulo, Melhoramentos, 1965.

ANGELLES, JEAN. Jack Farrell e a Ordem do Templo. Brasília, LGE, 2005.

APULEIO, LúcIO. O asno de ouro. Trad. Ruth Guimarães. São Paulo, Ediouro, s/d.

araúJo, Henry Correa de. Pivete. Belo Horizonte, Comunicação, 1977.

ARIÈS, PHILIPPE. História social da criança e da família. Trad. Dora Flaksman. 2. ed., Rio de Janeiro, LTC, 1981.

ARROYO, LEONARDO. Literatura Infantil brasileira. São Paulo, Melhoramentos, 1968.

AZEVEDO, RicARDo José DufF. “Como o ar não tem cor, se o céu é azul?" Vestígios dos contos populares na Literatura Infantil. Dissertação de Mestrado. Universidade de São Paulo. São Paulo, EECLLP-USP, 1998.

. Histórias de bobos, bocós, burraldos e paspalhões.

Porto Alegre, Projeto, 2001.

BASILE, GiAmBATTISTA. The pentamerone. Londres, John Lane the Bodley Head, 1932 APUd BETTELHEIM, BRuno. A psicanálise dos contos de fadas. Trad. Arlene Caetano. 15. ed. São Paulo, Paz e Terra, 1980.

BAYARD, JeAn-PierRe. História das lendas. Trad. Jeanne Marillier. São Paulo, Difusão Européia do Livro, 1957.

BETTElheim, Bruno. A psicanálise dos contos de fadas. Trad. Arlene Caetano. 15.ed. São Paulo, Paz e Terra, 1980.

Terra, 1997.

Na terra das fadas. Trad. Arlene Caetano. São Paulo, Paz e 
BRAGA, TEÓFILO. Contos tradicionais do povo português, Vol. I. 5. ed., Lisboa, Dom Quixote, 1999.

. Contos tradicionais do povo português. Vol. II., 4. ed., Lisboa, Dom Quixote, 1995.

BRAIT, Beth. A personagem. 7. ed., São Paulo, Ática, 2000.

BREDSDORFF, EliAS. Hans Christian Andersen - the story of his life and work. Londres, Souvenir Press, 1975.

BRUNEL, PIERRE. (org.) Dicionário de Mitos Literários. Rio de Janeiro, José Olympio, 1997.

BÜHLER, C. El desarollo espiritual del niño. Madri, 1934, pp. 324-6 APUD SOSA, Jesualdo, A literatura infantil. Trad. James Amado. São Paulo, Cultrix, 1978.

CALVINO, ITALO. Fábulas italianas. São Paulo. Cia. das Letras, 2000.

CALVINO, ITALO. Fiabe italiane. Milão, Mondadori, 1993.

Perché leggere i classici. Milão, Mondadori, 1995.

Sulla fiaba. Milão, Mondadori, 1996.

CAMPBELL, JosePh. O herói de mil faces. Trad. Adail Ubirajara Sobral. 7. ed., São Paulo, Cultrix, 2002.

O poder do mito. Trad. Carlos Felipe Moisés. 20. ed., São Paulo, Palas Athena, 1990.

CANDIDO, ANTONIO. "A personagem do romance" In: A personagem de ficção. São Paulo, Perspectiva, 1981.

CASCUDO, Luís da CÂMARA. Contos tradicionais do Brasil. 11. ed., Rio de Janeiro, Ediouro, 1998.

. Literatura oral no Brasil. 3. ed., São Paulo, EDUSP, 1984.

CAVALCANTI, IONALDO A. Esses incriveis heróis de papel. São Paulo, Mater, s/d.

CHKLOVSKI, V. "A construção da novela e do romance" In: VÁRIOS AUTORES. Teoria da Literatura: Formalistas russos. 4.ed., Porto Alegre, 1978. 
COElHo, Nelly Novaes. Panorama histórico da Literatura Infantil/Juvenil. 4.ed., São Paulo, Ática, 1991.

O conto de fadas, 3.ed., São Paulo, Ática, 1998.

Dicionário crítico da literatura infantil e juvenil brasileira.

São Paulo, EDUSP, 1995.

COLBERT, DAVID. O mundo mágico de Harry Potter. Trad. Rosa Amanda Strausz. Rio de Janeiro, Sextante, 2001.

COLLODI, Carlo. Le avventure di Pinocchio, 6. ed., Milão, Mondadori, 2001.

As aventuras de Pinóquio. Trad. Marina Colasanti. São Paulo, Cia. das Letrinhas, 2002.

CORSO, DIANA L. \& CORSO, MÁRIO. Fadas no divã: psicanálise nas histórias infantis. Porto Alegre, Artmed, 2006.

COUSTEL. Reglès de l'education des enfants, 1687 APUD ARIÈS, PHILIPPE. História social da criança e da família. Trad. Dora Flaksman. 2. ed., Rio de Janeiro, LTC, 1981.

CUNHA, MARIA ANTONIETA ANTUNES. Literatura Infantil - teoria e prática. 16. ed., São Paulo, Ática, 1997.

DIMENSTEIN, GILBERTO \& ORTIZ, ESMERALDA. Esmeralda, por que não dancei. São Paulo, Ática/ SENAC, 2000.

DONATO, HERNANI. "O folclore - base da literatura infantil". In: Curso de Literatura Infantil. São Paulo, Santos de Oliveira, s/d.

ENDE, Michael. A história sem fim. Trad. Maria do Carmo Cary e João Azenha Jr. 8. ed., São Paulo, Martins Fontes, 2001.

ESTÉS, C. P. Mulheres que correm com os lobos. Trad. Waldéa Barcellos. 12. ed., Rio de Janeiro, Rocco, 1999.

EVANS, C. STEPHAN. "Por que os super-heróis devem ser bons? Homem-Aranha, os X-Men e o duplo perigo de Kierkegaard" IN: MORRIS, MATT \& MORRIS, TOM. (ORG) Super-heróis e a filosofia. Trad. Marcos Leal. São Paulo, Madras, 2005. 
FAGUNDES, Antonio Augusto. Mitos e Lendas do Rio Grande do Sul. 7. ed., Porto Alegre, Martins Livreiro, 2000.

FERREIRA, JOAQUIM ALVES. Literatura popular de Trás-os-Montes e Alto Douro. Vol. V. Minerva Trasmontana, Vila Real, s/d.

FRASER, LINDSEY. Conversations with J. K. Rowling. New York, Scholastic, 2001.

GALIPEAU, STEVEn A. The journey of Luke Skywalker - An analysis of modern myth an symbol. Chicago, Open Court, 2001.

GIRARD, R. El Popol-Vuh, fuente histórica. Min. de Ed. Pública, Guatemala, 1952.

GÓES, LÚCIA PIMENTEL. Introdução à Literatura Infantil e Juvenil. São Paulo, Pioneira, 1984.

Em busca da Matriz. Contribuição para uma História da Literatura Infantil e Juvenil Portuguesa. São Paulo, Cliper, 1999.

A flauta do sótão. 2. ed., São Paulo, Paulus, 2005.

GONÇALVES, ANA CRISTINA C. Madrastas: do conto de fadas para o mundo real. São Paulo, Iglu, 1998.

GOTLIB, NÁDia Battella. Teoria do Conto. 10. ed., São Paulo, Ática, 2001.

GRIMM, JAKOB. Os contos de Grimm. Trad. Tatiana Belinky. 6. ed., São Paulo, Paulus, 1989.

GRIMM, JAKOB \& GRIMM, WILHELM. Contos de Grimm. Trad. David Jardim Júnior. Belo Horizonte, Itaitaia, 2000.

HENDERSON, MARY. Star Wars - the magic of the myth. New York, Bantam Books, 1997.

IRWIN, WILliam (ORG.). Harry Potter e a filosofia. Trad. Marcos e Martha Malvezzi Leal. São Paulo, Madras, 2004.

Star Wars e a filosofia. Trad. Marcos Malvezzi Leal. São Paulo, Madras, 2005.

JOLLES, ANDRÉ. Formas simples. Trad. Álvaro Cabral. São Paulo, Cultrix, 1930. 
JONES, BRuce; GARCIA, MANuel \& HANNA, Scott. Demolidor - O homem sem medo. Rio de Janeiro, Panini, 2003.

JUNG, C. G., ed. READ, HERBERT. The collected works. Londres, Routledge \& Kegan Paul, 1959, vol. 9 APUD SMITH, DONNA. Madrastas: mito e realidade. Trad. Rosaura Eichenberg. Porto Alegre, L\&PM, 1995.

KINDERSLEY, DORLING. Star Wars - The Power of myth. New York, DK, 1999.

LEE, Stan et al. Homem-Aranha. Rio de Janeiro, Marvel, 2002.

LEE, StAn \& DITKO, SteVe. The amazing fantasy. Nova York, Marvel, 1987.

LEGOUIS, ÉmILE. A short history of English Literature. 9. ed. Oxford, Clarendon, 1953.

LEWIS, Clive StAPLeS. The Lion, the Witch ande he Wardrobe - The Chronicles of Narnia. Nova York, HarperTrophy, 1994.

As crônicas de Nárnia. São Paulo, Martins Fontes, 2005.

LISBOA, HenRIQUetA. Literatura oral para a infância e a juventude. São Paulo, Peirópolis, 2002.

LOEB, JEPH \& MORRIS, TIM. "Heróis e Super-heróis" in: MORRIS, MATT \& MORRIS, TIM (ORG). Super-heróis e a filosofia. Trad. Marcos Leal. São Paulo, Madras, 2005, pp. 23-31.

LOPES NETO, JoÃo SIMÕES. Contos e lendas. Rio de Janeiro, Agir, 1957.

LUCAS, GeORgE. Star Wars - A new hope. Nova York, Ballantine, 1976.

. Star Wars - The star wars trilogy. Nova York, Ballantine, 1983.

Star Wars - Episode I: the phantom menace. Nova York, Ballantine, 1999.

. Star Wars - Attack of the clones. Nova York, Random House, 2002. 
MANGANELLI, GIorgıo. Pinóquio: um livro paralelo. Trad. Eduardo Brandão. São Paulo, Cia. das Letras, 2002.

MEIRELES, CeCíliA. Problemas de Literatura Infantil. 2. ed., São Paulo, Summus, 1979.

MILLER, Frank \& MAZZUCCHELLI, DAvid. Batman Ano Um. Rio de Janeiro, Panini, 2005.

MOISÉS, MASSAUD. A criação literária. 7. ed., São Paulo, Melhoramentos/ EDUSP, 1975.

MONTEIRO lobato, José Bento. Negrinha. 9. ed., São Paulo, Brasiliense, 1959. - A menina do narizinho arrebitado. São Paulo, Monteiro Lobato, 1920.

Reinações de Narizinho. 24. ed., São Paulo, Brasiliense, 1971.

MORRIS, MATT \& MORRIS, TIM (ORG). Super-heróis e a filosofia. Trad. Marcos Leal. São Paulo, Madras, 2005.

MOUTINHO, José VIALE (ORG.). Contos populares russos. São Paulo, Landy, 2000.

NUNES, Lygia Bojunga. A casa da madrinha. 19. ed., Rio de Janeiro, Casa Lygia Bojunga, 2003.

OPIE, IONA \& OPIE, PETER. The classic fairy tales. Oxford, Oxford University Press, 1974 APUD SMITH, DONNA. Madrastas: mito e realidade. Porto Alegre, L\&PM, 1995.

NEL, PHILIP. J. K. Rowling's Harry Potter novels. New York, Continuum, 2001.

OLIVEIRA, ANTENOR SANTOS. "A literatura infantil através dos tempos". In: Curso de Literatura Infantil. São Paulo, Santos de Oliveira, s/d.

ONG, WALTER. Oralidade e cultura escrita: a tecnologização da palavra. 11. ed., Campinas, Papirus, 1998.

PALlOtINI, RenATA. Dramaturgia - Construção do personagem. São Paulo, Ática, 1989. 
PALO, MARIA José \& OLIVEIRA, MARIA Rosa D. Literatura Infantil - Voz de criança. 2.ed., São Paulo, Ática, 1998.

PEPETELA. As aventuras de Ngunga. Lisboa, Edições 70, 1977.

PERRAUlt, Charles. Contos de Perrault. Trad. Regina Junqueira. 5. ed., Belo Horizonte, Villa Rica, 1999.

PINTO, Rolando MOREl. "Introdução a Doidinho" In: REGO, José LINS DO. Doidinho. 19. ed., Rio de Janeiro, José Olympio, 1979.

PRIETO, HeloísA. Balada. São Paulo, Brinque-Book, 2000.

Quer ouvir uma história? Lendas e mitos no mundo da criança. São Paulo, Angra, 1999.

PROPP, VLADIMIR. As raízes históricas do conto maravilhoso. Trad. Rosemary Costhek Abílio e Paulo Bezerra. 2. ed., São Paulo, Martins Fontes, 2002.

REGO, JosÉ LINS DO. Menino de Engenho. 10.ed., Rio de Janeiro, José Olympio,1966. . Doidinho. 19. ed., Rio de Janeiro, José Olympio, 1979.

ROSÁRIO, LoUREIRO. A narrativa africana de expressão oral. Luanda, Angolê, 1989. ROWLING, JoANNE K. Harry Potter e a pedra filosofal. Trad. Lia Wyler. Rio de Janeiro, Rocco, 2000.

Harry Potter e a câmara secreta. Trad. Lia Wyler. Rio de Janeiro, Rocco, 2000.

Harry Potter e o prisioneiro de Azkaban. Trad. Lia Wyler. Rio de Janeiro, Rocco, 2000.

Harry Potter e o cálice de fogo. Trad. Lia Wyler. Rio de Janeiro, Rocco, 2001.

Harry Potter e a Ordem da Fênix. Trad. Lia Wyler. Rio de Janeiro, Rocco, 2003. 
Harry Potter and the half-blood prince. Nova York, Scholastic,

2005.

SANTOS, ROBERTO ELísıo. Para reler os quadrinhos Disney - linguagem, evolução e análise de HQs. São Paulo, Paulinas, 2002.

SARMATZ, LEANDRO. "Um herói (quase) como a gente". Superinteressante. n. 177, 2002, pp. 36-42.

SILVA, Vitor Manuel de Aguiar. Teoria da Literatura. São Paulo, Martins Fontes, 1976.

SIMONSEN, MICHÈLE. O conto popular. São Paulo, Martins Fontes, 1987.

SIMPSON, EILEEN. Orphans: real and imaginary. Nova York, Penguin Books, 1990.

SMADJA, ISABelle. Harry Potter: as razões do sucesso. Trad. Ângela R. Viana e Antônio M. Guimarães. Rio de Janeiro, Contraponto, 2004.

SMITH, DonNA. Madrastas: mito e realidade. Trad. Rosaura Eichenberg. Porto Alegre, L\&PM, 1995.

SNICKET, LeMONY. Mau começo. Trad. Carlos Sussekind. São Paulo, Cia. das Letras, 2001.

A sala dos répteis. Trad. Carlos Sussekind. São Paulo, Cia. das Letras, 2001.

O lago das sanguessugas. Trad. Carlos Sussekind. São Paulo, Cia. das Letras, 2001.

- Serraria baixo-astral. Trad. Carlos Sussekind. São Paulo, Cia.

das Letras, 2002.

Inferno no colégio interno. Trad. Carlos Sussekind. São Paulo,

Cia. das Letras, 2002.

O elevador Ersatz. Trad. Carlos Sussekind. São Paulo, Cia. das

Letras, 2003

A cidade sinistra dos corvos. Trad. Carlos Sussekind. São Paulo, Cia. das Letras, 2003. 
. O hospital hostil. Trad. Carlos Sussekind. São Paulo, Cia. das

Letras, 2004.

- O espetáculo carnívoro. Trad. Carlos Sussekind. São Paulo,

Cia. das Letras, 2004.

O escorregador de gelo. Trad. Carlos Sussekind. São Paulo, Cia. das Letras, 2004.

SOSA, Jesualdo. A literatura infantil. Trad. James Amado. São Paulo, Cultrix, 1978.

VARGas, Maria ValíRIA A. DE Mello. Do Panchatantra a La Fontaine: tradição e permanência da fábula. Tese [doutorado]. São Paulo, FFLCH/USP, 1990.

TOLKIEN, J. R. R. The Lord of the Rings $-1^{\text {st }}$ Part: the fellowship of the Ring, 4. ed., Londres, Unwin Paperbacks, 1981.

The Lord of the Rings $-2^{\text {nd }}$ Part: the two towers, 4. ed., Londres, Unwin Paperbacks, 1981.

. The Lord of the Rings $-3^{\text {rd }}$ Part: the return of the King, 4. ed., Londres, Unwin Paperbacks, 1981.

VICtORIA, luiz Augusto Pereira. Dicionário básico de Mitologia. São Paulo, Ediouro, 2000.

WARNER, MARINA. Da fera à loira - sobre contos de fadas e seus narradores. Trad. Thelma Médici Nóbrega. São Paulo, Companhia das Letras, 1999.

WELLEK, RenÉ \& WARREN, Austin. Teoria da Literatura. Lisboa, Publicações Europa-América, s/d.

WREDE, PATRICIA C. Star Wars - Episode II - Attack of the clones. Nova York, Scholastic, 2002.

. Star Wars - Episode III - Revenge of the Sith. Nova York, Scholastic, 2005.

ZIPES, JACK. Fairy tale as myth - Myth as fairy tale. Kentucky, University Press, 1994. 


\section{FILMES E ANIMAÇÕES}

\section{FILMES:}

A PRINCESINHA (A little princess). Direção de Alfonso Cuarón. Los Angeles, Warner Bros./ Baltimore Pictures. Distribuição: Warner Bros., 1995. 1 filme (97 min.): son.; color.; $16 \mathrm{~mm}$.

A.I. INTELIGÊNCIA ARTIFICIAL (A. I. Artificial Inteligence). Direção de Steven Spielberg. Los Angeles, DreamWorks SKG / Warner Bros. / Stanley Kubrick Productions. Distribuição: DreamWorks Distribution L.L.C. / Warner Bros., 2001. 1 filme (128 min.): son.; color.; $16 \mathrm{~mm}$.

BATMAN BEGINS. Direção de Christopher Nolan. Los Angeles, Warner Bros./ Di Boaventura Pictures. Distribuição: Warner Bros., 2005. 1 filme (134 min.): son.; color.; $16 \mathrm{~mm}$.

DEMOLIDOR - O HOMEM SEM MEDO (Daredevil). Direção de Mark Steven Johnson. Los Angeles, $20^{\text {th }}$ Century Fox / Marvel Entertainment / New Regency Pictures / Horseshoe Bay Productions. Distribuição: $20^{\text {th }}$ Century Fox, 2003. 1 filme (101 min.): son.; color.; $16 \mathrm{~mm}$.

DESVENTURAS EM SÉRIE (Lemony Snicket's A Series of Unfortunate Events). Direção de Brad Silberling. Los Angeles, Paramount Pictures / DreamWorks SKG / Scott Rudin Productions / Nickelodeon Movies. Distribuição: Paramount Pictures / DreamWorks Distribution LLC / UIP, 2004. 1 filme (113 min.): son.; color.; 16mm.

GUERRA NAS ESTRELAS - EPISÓDIO IV: UMA NOVA ESPERANÇA (Star Wars - Episode IV: $A$ new hope). Direção de George Lucas. Los Angeles, LucasFilm. Distribuição: $20^{\text {th }}$ Century Fox Film Corporation, 1977. 1 filme (121 min.): son.; color.; 16mm.

GUERRA NAS ESTRELAS - EPISÓDIO V: O IMPÉRIO CONTRA-ATACA (Star Wars - Episode $V$ : The Empire strikes back). Direção de Irvin Kershner. Los Angeles, LucasFilm. Distribuição: $20^{\text {th }}$ Century Fox Film Corporation, 1980. 1 filme (124 min.): son.; color.; $16 \mathrm{~mm}$.

GUERRA NAS ESTRELAS - EPISÓDIO VI: O RETORNO DE JEDI (Star Wars - Episode VI: Return of the Jedi). Direção de Richard Marquand. Los Angeles, LucasFilm. Distribuição: $20^{\text {th }}$ Century Fox Film Corporation, 1983. 1 filme (131 min.): son.; color.; $16 \mathrm{~mm}$.

HARRY POTTER E A CÂMARA SECRETA (Harry Potter and the chamber of the secrets). Direção de Chris Columbus. Los Angeles, Warner Bros./ 1492 Pictures/ Heyday Films. Distribuição: Warner Bros., 2002. 1 filme (161 min.): son.; color.; $16 \mathrm{~mm}$.

HARRY POTTER E A PEDRA FILOSOFAL (Harry Potter and the sorcerer stone). Direção de Chris Columbus. Los Angeles, Warner Bros./ Heyday Films. Distribuição: Warner Bros., 2001. 1 filme (152 min.): son.; color.; $16 \mathrm{~mm}$.

HARRY POTTER E O CÁLICE DE FOGO (Harry Potter and the goblet of fire). Direção de Mike Newell. Los Angeles, Warner Bros./ Heyday Films. Distribuição: Warner Bros., 2005. 1 filme (157 min.): son.; color.; $16 \mathrm{~mm}$. 
HARRY POTTER E O PRISIONEIRO DE AZKABAN (Harry Potter and the prisioner of the Azkaban). Direção de Alfonso Cuarón. Los Angeles, Warner Bros./ 1492 Pictures/ Heyday Films. Distribuição: Warner Bros., 2004. 1 filme (139 min.): son.; color.; 16mm.

HOMEM-ARANHA (Spider-Man). Direção de Sam Raimi. Los Angeles, Columbia Pictures/ Sony Pictures Entertainment/ Marvel Entertainment. Distribuição: Columbia Pictures/ Sony Pictures Entertainment, 2002. 1 filme (128 min.): son.; color.; 16mm.

HOMEM-ARANHA 2 (Spider-Man 2). Direção de Sam Raimi. Los Angeles, Columbia Pictures/ Sony Pictures Entertainment/ Marvel Entertainment. Distribuição: Columbia Pictures/ Sony Pictures Entertainment, 2004. 1 filme (127 min.): son.; color.; 16mm.

HULK (The Hulk). Direção de Ang Lee. Los Angeles, Universal Pictures / Marvel Entertainment / Good Machine / Valhalla Motion Pictures / Pacific Western. Distribuição: Universal Pictures / UIP, 2003. 1 filme (135 min.): son.; color.; 16mm.

JANE EYRE. Direção de Robert Stevenson. Los Angeles, $20^{\text {th }}$ Century Fox. Distribuição: $20^{\text {th }}$ Century Fox Corporation, 1944. 1 filme (96 min.): son.; color.; $16 \mathrm{~mm}$.

O GAROTO (THE KID). Direção de Charles Chaplin. E.U.A., First National Pictures Inc., 1921. 1 filme (68 min.): p\&b.; $16 \mathrm{~mm}$.

O JARDIM SECRETO (The secret garden). Direção de Agnieszka Holland. Los Angeles, Warner Bros./ American Zoetrope. Distribuição: Warner Bros., 1993. 1 filme (101 min.): son.; color.; $16 \mathrm{~mm}$.

OLIVER TWIST. Direção de Roman Polanski. Inglaterra/ República Tcheca/ França/ Itália, Runteam Ltd. / ETIC Limited / Medusa Produzione / R.P. Productions. Distribuição: Sony Pictures Entertainment / TriStar Pictures, 2005. 1 filme (130 min.): son.; color.; $16 \mathrm{~mm}$.

REGRAS DA VIDA (The cider house rules). Direção de Lasse Hallström. Los Angeles, Miramax Films. Distribuição: Miramax Films, 1999. 1 filme (130 min.): son.; color.; $16 \mathrm{~mm}$.

STAR WARS - EPISÓDIO I: A AMEAÇA FANTASMA (Star Wars - Episode I: The Phantom Menace). Direção de George Lucas. Los Angeles, LucasFilm. Distribuição: $20^{\text {th }}$ Century Fox Film Corporation, 1999. 1 filme (131 min.): son.; color.; 16mm.

STAR WARS - EPISÓDIO II: ATAQUE DOS CLONES (Star Wars - Episode II: Attack of the clones). Direção de George Lucas. Los Angeles, LucasFilm/ JAK Productions. Distribuição: $20^{\text {th }}$ Century Fox Film Corporation, 2002. 1 filme (144 min.): son.; color.; $16 \mathrm{~mm}$.

STAR WARS - EPISÓDIO III: A VINGANÇA DOS SITH (Star Wars - Episode III: Revenge of the Sith). Direção de George Lucas. Los Angeles, LucasFilm. Distribuição: $20^{\text {th }}$ Century Fox Film Corporation, 2005. 1 filme (146 min.): son.; color.; $16 \mathrm{~mm}$. 


\section{ANIMAÇÕES:}

A ERA DO GELO (Ice Age). Direção de Chris Wedge. Los Angeles, Fox Animation Studios / Blue Sky Studios. Distribuição: $20^{\text {th }}$ Century Fox Film Corporation, 2002. Animação (115 min.): son.; color.; 16mm.

BRANCA DE NEVE E OS SETE ANÕES (Snow White and the Seven Dwarfs). Direção de David Hand. Los Angeles, Walt Disney Pictures. Distribuição: RKO Radio Pictures Inc. / Buena Vista Pictures, 1937. Animação (83 min.): son.; color.; 16mm.

LILO \& STITCH. Direção de Dean Deblois e Chris Sanders. Los Angeles, Walt Disney Productions. Distribuição: Buena Vista Pictures, 2002. Animação (85 min.): son.; color.; $16 \mathrm{~mm}$.

O GaLINHO (Chicken Little). Direção de Mark Dindal. Los Angeles, Walt Disney Productions. Distribuição: Buena Vista Pictures, 2005. Animação (77 min.): son.; color.; $16 \mathrm{~mm}$.

O PRÍNCIPE DO EGITO (The Prince of Egypt). Direção de Brenda Chapman, Simon Wells e Steve Hickner. Los Angeles, DreamWorks SKG. Distribuição: DreamWorks Distribution L.L.C. / UIP, 1998. Animação (98 min.): son.; color.; 16mm.

O REI LEÃO (The lion king). Direção de Roger Allers e Rob Minkoff. Los Angeles, Walt Disney Productions. Distribuição: Buena Vista Pictures, 1994. Animação (88 min.): son.; color.; $16 \mathrm{~mm}$.

PROCURANDO NEMO (Finding Nemo). Direção de Andrew Stanton. Los Angeles, Pixar Animation Studios / Walt Disney Productions. Distribuição: Buena Vista Pictures / Walt Disney Pictures, 2003. Animação (101 min.): son.; color.; 16mm.

ROBÔS (Robots). Direção de Chris Wedge. Los Angeles, Fox Animation Studios / Blue Sky Studios. Distribuição: $20^{\text {th }}$ Century Fox Film Corporation, 2005. Animação (90 min.): son.; color.; $16 \mathrm{~mm}$. 


\section{FONTES ELETRÔNICAS ONLINE}

Fontes eletrônicas online consultadas ou acessadas no formato/ protocolo: http (hypertext transfer protocol) usado pelo www (world wide web):

OliVEIRA, CRistiane MadANElo. "Presença da fada-madrinha nas versões do conto Cinderela" Disponível em <http://www.graudez.com.br/litinf/trabalhos/contosde fadas. htm> Acesso em 02/10/2005.

REUTERS. "Magia de Homem-Aranha completa 40 anos na Marvel". IN: Folha Online, 16/05/2002. Disponível em <http://www1.folha.uol.com.br/folha/reuters/ult112u 15950.shl> Acesso em 05/12/2005.

VIANA, N. "A era da aventura no mundo dos quadrinhos". IN: Revista Espaço Acadêmico, n. 35. Abril, 2004, pp. 1-4. Disponível em <http://www.espaco academico.com.br/035/35cviana.htm> Acesso em 11/12/2005.

\section{SITES CONSULTADOS - Acesso entre 30/05/2005 e 31/01/2006}

<http://adorocinema.cidadeinternet.com.br/filmes>

<http://dedalus.usp.br:4500/ALEPH/por/USP/USP/DEDALUS/START>

<http://en.wikipedia.org/wiki/List_of_The_Amazing_Spider-Man_comics>

$<$ http://harrypotter.warnerbros.com>

<http://home.freeuk.net/webbuk2/harrypotter.htm>

<http://nationalgeographic.abril.uol.com.br>

$<$ http://web.ipn.pt/literatura/letras>

<http://www.admbrasil.com.br/abnt.htm>

$<\mathrm{http}: / /$ www.agalaxia.com.br/cinema/resenhas $>$

$<$ http://www.blueharvest.net>

$<\mathrm{http}: / /$ www.britannica.com>

<http://www.burburinho.com/20020404.html>

$<$ http://www.cinepop.com.br/index.html>

<http://www.citi.pt/cultura/literatura/romance>

$<h t t p: / / w w w . d e v i r . c o m . b r>$ 
$<$ http://www.dobrasdaleitura.com/index.html>

<http://www.edukbr.com.br/artemanhas/cinema_orig.asp>

$<\mathrm{http}: / /$ epipoca.cidadeinternet.com.br >

<http://www.espacoacademico.com.br >

$<$ http://www.estadao.com.br>

<http://www.graphiqbrasil.com/clássicos/ gwenstacy.html>

<http://www.guiadoscuriosos.com.br>

$<$ http://www.iplb.pt>

$<$ http://www.marvelcomics.com>

<http://www.mundocultural.com.br>

<http://www.omelete.com.br/quadrinhos/artigos/base_para_artigos.asp?artigo=774>

$<$ http://www.online-literature.com>

<http://www.presidenciarepublica.pt/pt/palacio/presidentes/teofilo_braga.html>

<http://www.samruby.com/AmazingSpider-ManD>

<http://www.scholastic.com/harrypotter/home.asp>

$<$ http://www.sergeicartoons.com>

$<\mathrm{http}: / /$ www.starwars.com>

<http://www.toon.com/info/Disney_Classic.html>

<http://www.ufscar.br/ cinemais/artcinehq.html>

$<$ http://www.uweb.ucsb.edu>

<http://www.webcine.com.br/historia1.htm> 
APÊNDICE CONTOS POPULARES 
Neste Apêndice estão reproduzidos na íntegra os contos populares analisados no Capítulo 1 desta Dissertação, a saber:

I) O espelho mágico, recolha de Câmara Cascudo;

II) Almofadinha de ouro, recolha de Câmara Cascudo;

III) A gata borralheira, recontada por Viale Moutinho;

IV) A história de João, recontada por Henriqueta Lisboa;

v) As três casinhas, recolha de Italo Calvino;

vı) Os três órfãos, recolha de Italo Calvino;

VII) A madrasta, recolha de Teófilo Braga;

VIII) O sapatinho de cetim, recolha de Teófilo Braga;

IX) A princesa dos cabelos de oiro, recontada por Joaquim A. Ferreira;

x) O rapaz do Conho, recolha de Lourenço Rosário. 


\section{I) Recolha de Câmara Cascudo no Brasil, Rio Grande do Norte ${ }^{1}$}

\section{O ESPELHO MÁGICO}

O rapaz, órfão de pai e mãe, saiu pelo mundo para ganhar a vida. la por um caminho quando viu uma pedra tapando a boca de um formigueiro e as formigas lutando para arredá-la. O moço que tinha bom coração, abaixou-se e tirou a pedra com cuidado para não matar as formigas. Quando acabou, uma formiguinha falou:

- Se você se encontrar em dificuldades, diga: "Valha-me rei das formigas".

O rapaz seguiu sua estrada e adiante encontrou um carneiro com uma pata enganchada num arame. Soltou o bichinho. O carneiro disse:

- Quando você tiver uma dificuldade, diga: "Valha-me o rei dos carneiros!"

Lá mais longe o rapaz viu um peixe dentro duma poça d'água rasa, quase se acabando. O peixe estava com o lombo de fora, morrendo. O moço tirou-o da poça e sacudiu numa lagoa perto. O peixe mergulhou, foi embaixo, veio em cima, e falou:

- Quando você tiver uma dificuldade, diga: "Valha-me o rei dos peixes."

Quase avistando o reinado, o rapaz encontrou um gavião deitado no chão, seco de sede. Levou-o, deu-lhe um banho, deixou ele beber água e soltou. $\mathrm{O}$ gavião voou para um galho de pau e disse:

- Quando você tiver uma dificuldade, diga: "Valha-me o rei dos pássaros!"

Chegando no reinado, o rapaz soube que a princesa tinha um espelho mágico que mostrava todas as cousas escondidas. O espelho só tinha forças de meia-noite até o primeiro cantar do galo. Quem se escondesse e a princesa não descobrisse, casava com ela e, se ela achasse, perdia o homem a vida. $O$ pretendente tinha três noites para lograr sucesso. O rapaz foi se oferecer para essa aventura.

Na primeira noite, procurou um canto fora do reinado e disse: "Valha-me o Rei dos Carneiros!" O carneiro apareceu e o rapaz disse o que queria.

- Monte nas minhas costas! - O rapaz montou e o carneiro largou-se correndo, de mato a dentro, para umas brenhas fechadas onde havia uma gruta.

${ }^{1}$ CASCUDO, L. C. Op. cit., pp. 88-90. 
Deitou o rapaz na gruta e encheu os arredores de carneiros, uns por cima dos outros, que ninguém via outra cousa afora carneiro.

À meia-noite a moça puxou o espelho e procurou o rapaz, por todos os lados. Tanto virou que deu com a gruta e o espelho mostrou o rapaz deitado no chão, coberto de carneiros. A princesa tomou nota e foi dormir.

No outro dia, o rapaz se apresentou.

- Onde eu estava escondido?

- Deitado no chão, dentro de uma gruta, rodeado de carneiros!

- Era isso mesmo!

O rapaz apelou para o peixe. Foi à beira-mar e chamou: Valha-me o rei dos peixes! O peixe riscou na praia. O moço contou sua dificuldade. $O$ rei dos peixes mandou um tubarão engolir o rapaz e uma baleia engolir o tubarão e foi para o fundo do mar.

À meia-noite, a princesa foi consultar o espelho. Caçou na terra e nos ares e procurou nos mares, com tanto cuidado que descobriu onde o rapaz estava dormindo. Na manhã, o moço apareceu e perguntou:

- Onde eu passei a noite?

- Dentro de um tubarão, este numa baleia, no fundo do mar!

- Era isso mesmo!

Dessa vez o rapaz chamou o gavião e contou sua agonia. O gavião levou-o nas costas até em cima das nuvens e lá apareceu outro gavião ainda maior que cobriu o rei dos pássaros com suas asas.

À meia-noite, a princesa procurou o rapaz nas águas e na terra e não achou. Procurou nos ares e não viu. Tanto olhou e olhou que enxergou um pontinho escuro por cima das nuvens. Botou reparo e descobriu tudo. O rapaz, quando veio ao palácio, perguntou:

- Onde dormi a noite passada?

- Em cima de um gavião, coberto por outro, em cima das nuvens!

- Era isso mesmo!

Como era o terceiro dia, o rapaz foi condenado à morte mas a princesa ficou com pena dele e pediu ao rei para deixar o moço experimentar uma vez mais. O rapaz ficou contente e foi valer-se do rei das formigas. Esse ouviu a conversa toda e disse: 
- O espelho descobriu você na terra, na água e nos ares. Mas o espelho não pode ver a própria princesa. Eu vou virar você numa formiga e você suba para cima do vestido dela e esconda-se bem.

Dito e feito. O rapaz virou formiga, entrou no palácio, foi ao quarto da princesa e subiu pelo vestido acima, bem devagar para ela não pressentir, e escondeu-se na bainha da camisa.

À meia-noite, a princesa procurou o rapaz em toda parte, virou e mexeu, e nada de ver onde ele estava dormindo. Passou-se a hora das forças do espelho encantado e ela não viu cousa alguma. Amanheceu o dia e o rapaz voltou a ser gente e veio perguntar onde tinha dormido.

- Não sei onde você dormiu! Onde foi?

- Não digo enquanto não me casar com você!

Fizeram o casamento com muita festa e só depois de casado é que o moço tinha onde tinha passado a sua última noite de solteiro. 


\section{II) Recolha de Câmara Cascudo no Brasil, Rio Grande do Norte ${ }^{2}$}

\section{ALMOFADINHA DE OURO}

Era uma vez uma menina muito bonita e graciosa, filha única, e que teve a infelicidade de ficar órfã de mãe. Seu pai ainda ficou moço e casou novamente, com uma viúva que tinha uma filha, pondo-se mocinha e muito feia e orgulhosa. $A$ madrasta, na presença do marido, tratava a enteada bem, mas como esse vivia viajando, vingava-se, obrigando-a a trabalhos pesados, como lavar roupa, limpar a estrebaria, o galinheiro, a casa inteira, etc. A mocinha começou a viver amargurada e sofrendo toda a espécie de privações e insultos. De tanto padecer, perdeu a paciência e achou que o remédio era fugir daquele purgatório.

Antes de tomar essa decisão, a moça rezava todas as noites à Nossa Senhora, que era sua madrinha, pedindo que lhe ensinasse os caminhos do bom proceder. Nossa Senhora virou-se numa velhinha e falou com ela no caminho do rio, explicando tudo. Abençoou-a e the deu uma almofadinha de ouro que era encantada. Quando precisasse de alguma cousa, pedisse à almofadinha de ouro que fora dotada por Deus com poderes.

Deixando a casa, a moça andou muitos dias, com fome e sede, e acabou encontrando uma ocupação num palácio vistoso, residência de um príncipe solteiro e muito agradável.

A moça, para não causar suspeitas e despertar maldades, sujou o rosto e andava tão imunda que só lhe deram o serviço de tratar das galinhas e dos porcos, dormindo no fundo de um quintal, num quartinho escuro e isolado do palácio.

Dia vai e dia vem, anunciaram três dias de festas e toda a gente ficou influída para esse divertimento preparando as roupas novas, encomendando os arranjos e fazendo cálculos. O príncipe era um dos mais alegres e as moças da cidade desejavam que ele se engraçasse com uma delas e casasse, por ocasião das festas.

Chegando o primeiro dia, o príncipe foi para o baile e os empregados do palácio fugiram para ver as luzes e a entrada das pessoas que iam dançar. A princesa-velha, mãe do príncipe, foi também.

\footnotetext{
${ }^{2}$ Idem, pp. 67-70.
} 
Ficando sozinha, a moça tomou banho, penteou-se e pediu à almofadinha de ouro que lhe desse um vestido cor do campo com suas flores e uma carruagem com criados.

Apareceu, incontinenti, o pedido, e a moça vestiu-se e compareceu à festa, causando um assombro pela sua formosura e lindeza do traje. O príncipe largou todas as outras e só dançou com ela. Como lembrança do encontrou, fez-lhe presente de um anel. perto da meia-noite, a moça desapareceu, fugindo para casa onde trocou a roupa, o vestido e o carro sumiram.

no segundo dia aconteceu a mesma cousa. A moça levou um vestido cor do mar com todos os seus peixinhos e o príncipe ficou encantado por ela, dançando, servindo-a e conversando. Deu-lhe uns brincos. Antes da meia-noite, a moça não foi encontrada em parte alguma. já estava em casa, suja e feia como habitualmente parecia aos olhos de todos.

No terceiro dia, o mesmo sucedido. Desta vez o vestido era da cor do céu com todos os seus astros e a moça encandiava a vista pelo brilho das jóias. $\mathrm{O}$ príncipe só faltava gritar de contente. Presenteou-lhe um colar e ficou triste quando ela desapareceu, antes da meia-noite.

Passados os três dias, só se falava na cidade naquele assunto da moça desconhecida, com os três vestidos mais bonitos do mundo. O príncipe procuroua como um cego procura a luz e não a encontrou em parte alguma. Estava tão apaixonado que adoeceu de cama, trancou-se no quarto e só deixava entrar sua mãe. Todo mundo lastimava a doença do príncipe e os médicos não tinham mais remédio para aconselhar nem receita que servisse. O príncipe nem queria comer e a princesa-velha fazia as maiores promessas para que o filho se alimentasse, fosse como fosse.

Um dia a moça disse à princesa-velha que queria fazer um bolo para 0 príncipe doente. A princesa achou graça no atrevimento, mas tanto a moça pediu e rogou que obteve o consentimento. Preparou-se, foi para a cozinha e fez um bolo dourado, colocando dentro da massa o anel que o príncipe lhe dera na primeira noite do baile.

O príncipe nem queria ver a comida, mas sua mãe tanto pediu que ele cortou um pedaço do bolo e, ao levar à boca, reparou num objeto que aparecia na parte restante no prato. Puxou com o bico da faca e reconheceu o anel. Comeu todo o bolo, melhorando, e declarou que queria outro bolo feito pela mesma 
pessoa. A moça fez o outro bolo e neste mandou a pulseira, que o príncipe achou e ficou certo que a moça estava por perto. Pediu outro bolo e neste veio o colar. Então, sem ter mais dúvida, disse à princesa-velha que mandasse ao seu quarto quem fizera os três bolos. A princesa obrigou a moça a mudar de roupa, perfumar-se, para tirar o mau cheiro do galinheiro, e disse que se apresentasse ao seu filho.

A moça subiu a escada, com a almofadinha de ouro na mão, e assim que bateu na porta, pediu que lhe aparecesse no corpo o vestido do terceiro dia da festa, dos pés à cabeça. Quando a porta se abriu e ela entrou, o príncipe deu um grito de alegrai, levantou-se da coma, bonzinho de saúde, chamando pela mãe e mostrando a moça que estava mis bonita do que nas noites passadas.

Casaram-se imediatamente, contando a moça sua história, e foram felizes até a morte. 


\section{III) Versão russa de "A Gata Borralheira" recontada por Viale Moutinho}

\section{A GATA BORRALHEIRA}

Era uma vez uma menina pequenina, que já não tinha pai nem mãe. Ora uma família muito ruim encarregou-se de criá-la.

Quando estava crescida obrigaram-na a mourejar e a responder a todos por tudo. A patroa dela tinha três filhas. A mais velha chamava-se Um Olho, a do meio Dois-Olhos e a mais nova tinha o nome de Três-Olhos. Mas elas só sabiam estar à janela e a menina tinha de trabalhar pelas quatro, e ainda era maltratada.

Um dia, a menina foi para o campo coma a vaquinha malhada e contou-lhe todas as miséias da vida a que estava sujeita, dizendo-lhe:

- Ah, vaquinha, ah, mamãe! Batem-me, ralam-me, não me dão um bocadinho de pão, e ainda por cima não me deixam chorar. Para amanhã tenho que fiar, colar, tecer cinco puds de lã.

A vaquinha respondeu-lhe:

- Linda menina! Entra-me por um dos ouvidos e sai pelo outro, e tudo estará feito.

Assim foi. Quando a menina saiu do ouvido da vaca encontrou todo o trabalho pronto e levou-o à patroa.

A mulher olhou para o trabalho murmurando e guardou-o numa mala. Depois deu à menina ainda mais trabalho. A menina foi outra vez ter com a vaca e, entrando-Ihe por um ouvido e saindo pelo outro, encontrou tudo pronto. Depois levou a obra à patroa. Esta ficou admirada e disse para Um-Olho:

- Querida filha! Vai ver quem é que ajuda a órfã a fiar, dobrar e tecer a lã.

Um-Olho foi para o campo com a menina e esqueceu-se da ordem da mãe. Estendeu-se na erva ao sol, enquanto a menina cantava:

- Dorme, dorme, olhinho!

Um-Olho adormeceu. Entretanto, a vaca fez todo o trabalho. Ora como a patroa não soube de nada, mandou Dois-Olhos.

Esta também se estendeu na erva ao sole esqueceu-se da ordem da mãe. A menina cantou-lhe:

- Dorme, dorme, dois-olhinhos!

\footnotetext{
${ }^{3}$ MOUTINHO, V. Op. cit., pp. 95-98.
} 
Apanhando-a dormindo, a vaca fez o trabalho. Ele ficou pronto e a DoisOlhos não tinha ainda acordado. A velha zangou-se, e no terceiro dia, mandou Três-Olhos com a órfã, a quem deu ainda mais trabalho.

Três-Olhos fez como as irmãs mais velhas. Pulou, pulou e depois estendeu-se na erva.

A menina cantou-lhe:

- Dorme, dorme, dois-olhinhos!

Esqueceu-se do terceiro olho.

Dois olhos adormeceram, mas o terceiro olhava e via tudo. Assim ficou sabendo como a menina entrou num ouvido da vaca e saiu pelo outro, apanhando a obra feita. Três-Olhos contou depois à mãe tudo quanto tinha visto. A velha ficou muito contente e no dia seguinte disse ao marido:

- Mata a vaca malhada.

Ele não queria matá-la e disse para a mulher:

- Estás doida? A vaca ainda é tão nova e tão bonitinha!

A mulher retrucou-lhe:

- Mata-a e não quero saber do resto!

$O$ velho afiou uma faca, mas a menina foi depressa ter com a vaquinha e contou-lhe:

- Ah, vaquinha, ah, mamãe! Querem matar-te!

A vaca falou de novo:

- Pois bem, minha linda menina. Não comas a minha carne. Junta os meus ossos num lenço e planta-os no quintal. Mas não te esqueças de me regares todos os dias.

A menina fez tudo o que a vaquinha mandou, chegou a passar fome, mas não quis provar a carne. $E$ todos os dias, sem falta, regava os ossos no quintal.

Ora, dos ossos nasceu uma admirável macieira com folhas de ouro e ramos de prata. Quem passava pela macieira, parava e não se fartava de olhar para ela.

Aconteceu uma vez que as moças andavam brincando no quintal. Nisto passou um jovem rico fidalgo. Quando viu as maçãs disse para as moças:

- Meninas! Aquela de vós que me oferecer uma maçã casará comigo!

As três irmãs puseram-se a correr em direção à macieira. As maçãs pendiam muito baixo e parecia que se podiam alcançar só com o estender do 
braço. Mas quando as três irmãs chegaram junto da árvore, os ramos subiram que elas não tiveram possibilidades de colher os frutos. As irmãs ainda atiraram pedras às maçãs, mas as folhas tapavam-lhe os olhos. Quiseram subir com um escadote, mas os ramos afastavam-nas aos empurrões. Em suma, tudo o que fizessem lhes saía trocado.

Nisso chegou a menina, foi à árvore e colheu uma maçã, pois os frutos aproximaram-se dela. E assim o fidalgo casou com a órfã e viveram muito felizes. 


\section{IV) Conto popular recontado por Henriqueta Lisboa ${ }^{4}$}

\section{HISTÓRIA DE JOÃO}

Houve um homem que teve um filho chamado João; morrendo o pai, o filho herdou um gato, um cachorro, três braças de terra e três pés de bananeira. João deu o cachorro ao vizinho, vendeu as bananeiras e as terras, e comprou uma viola. Foi tocar no pastorador das ovelhas do rei; quando o pastor chegava, ele se escondia, e nunca o pastor podia ver quem tocava a viola. As ovelhas, já muito acostumadas com o som da viola, não queriam mais se recolher ao curral, e quando o vaquejador as perseguia elas se metiam pelo mato, e cada dia desaparecia uma cabeça. João as ia juntando e exercitando ao som da viola todas as manhãs e tardes, e acostumando-as com o gato seu companheiro. O rei, vendo as suas ovelhas sumidas, e pensando ser desmazelo do pastor, o despediu. Vindo João à feira fazer compras para levar para o mato, viu um criado do rei procurando um homem ou menino que quisesse ser pastejador de suas ovelhas. Logo que o criado viu a João, se agradou dele e disse:

- Amarelo, queres tu servir ao rei como seu pastor?

Respondeu João:

- Que qualidade de rei é este que não caça e pasta no mato e precisa de ser pastorado? Esse rei é de pena, pêlo ou cabelo?

O criado insultou-se e disse-lhe:

- Como te chamas?

João respondeu:

- O menino ditoso.

O criado tomou-lhe o nome e largou-se para o palácio, e contou ao rei o que se tinha passado. Logo o rei mandou buscar o Ditoso debaixo de prisão. Chegou João com a sua viola e o gato metido num saco, e disse:

- Deus salve, rei senhor, Nesta vossa monarquia! Salve a mim primeiramente E depois a companhia

\footnotetext{
${ }^{4}$ LISBOA, HenRIQUETA. Literatura oral para a infância e a juventude. São Paulo, Peirópolis, 2002, pp. 123-124.
} 
Disse o rei:

- Saibas que estás com sentença de morte, se não deres conta de todas as ovelhas que fugiram do rebanho.

Respondeu o Ditoso:

- Eu sei lá quantas ovelhas faltam ao rebanho!

Disse o rei:

- Fugiram mil, e quero todas aqui.

Retirou-se o João bem fresco; foi para o mato e deitou-se a dormir, e o gato foi caçar rolas para o jantar. Chegando a tarde, acordou o Ditoso e vou que nada ainda tinha feito, e pôs-se a tocar viola. Logo se reuniram todas as ovelhas, que eram duas mil e trezentas. Ele foi tocando a viola e seguindo para o palácio do rei, e as ovelhas foram acompanhando. O rei ficou espantado de ver tantas ovelhas, e disse-lhe:

- Como pudeste ajuntar tantas ovelhas?

Respondeu:

- Achei-as à toa.

- Serão todas minhas? - perguntou o rei.

- Quem sabe não sou eu: veja se as conhece, eu trouxe as que eu encontrei.

- Tu agora tomarás conta do rebanho, que agora és meu pastor.

No outro dia, antes de o Sol sair, o Ditoso pediu que batessem na porta do rei e dissessem que era tempo de seguirem para o mato. O rei acorda e chega à janela e diz:

- Vai, Ditoso, vai pastorar.

O Ditoso respondeu:

- Não posso sair sem rei, senhor, seguir no meio do rebanho, visto ser eu seu pastor, como disse.

- És o pastor das ovelhas do rei - disse este.

- Agora sim - respondeu João -, já me convenço de que o rei, meu senhor, não é de lã, nem de pena ou pêlo: é rei de cabelo.

Nisto seguiu com o gato e as ovelhas para o mato. 


\section{v) Conto italiano recolhido em Mântua por Italo Calvino ${ }^{5}$}

\section{AS TRÊS CASINHAS}

Ao morrer, uma pobre mulher chamou as três filhas e falou assim:

- Minhas filhas, dentro em pouco estarei morta e vocês vão ficar sozinhas no mundo. Quando eu não estiver mais aqui, façam assim: procurem seus tios e peçam que construam uma casa para cada uma. Queiram-se bem. Adeus. - E expirou. As três moças saíram chorando.

Puseram-se a caminho e encontraram um tio, fabricante de esteiras. Catarina, a mais velha, disse:

- Tio, nossa mãe morreu; o senhor, que é tão bom, faça uma casinha de esteiras para mim.

E o tio, fabricante de esteiras, fez a casinha de esteiras para ela.

As outras duas irmãs seguiram em frente e encontraram um tio, marceneiro. Disse Júlia, a do meio:

- Tio, nossa mãe morreu; o senhor, que é tão bom, faça uma casinha de madeira para mim.

E o tio, marceneiro, fez a casinha de madeira para ela.

Restou só Marieta, a caçula, e seguindo o seu caminho, encontrou um tio, ferreiro.

- Tio - disse-lhe -, mamãe morreu; o senhor, que é tão bom, faça uma casinha de ferro para mim.

E o tio, ferreiro, fez a casinha de ferro para ela.

À noite, apareceu o lobo. Foi à casinha de Catarina e bateu à porta. Catarina perguntou:

- Quem é?

- Sou um pobre pintinho, todo molhado; abra para mim por caridade.

- Vá embora; você é o lobo e quer me devorar.

O lobo deu um empurrão nas esteiras, entrou e devorou Catarina de uma só vez.

No dia seguinte, as duas irmãs foram visitar Catarina. Encontraram as esteiras arrancadas e a casinha vazia.

${ }^{5}$ CALVINO, I. Op. cit., 2000, pp. 84-87. 
- Oh, coitadas de nós! - disseram. - Certamente o lobo engoliu nossa irmã mais velha.

Ao anoitecer, reapareceu o lobo e foi à casa de Júlia. Bateu, e ela:

-Quem é?

- Sou um pobre pintinho desgarrado; dê-me abrigo, por piedade.

- Não, você é o lobo e quer me devorar como fez com minha irmã.

O lobo deu um empurrão na casinha de madeira, escancarou a porta e Júlia sumiu na goela dele.

De manhã, Marieta vai visitar Júlia, não a encontra e diz com seus botões: "O lobo a devorou! Pobre de mim, fiquei sozinha nesse mundo".

À noite, o lobo foi à casa de Marieta.

-Quem é?

- Sou um pobre pintinho gelado de frio, estou lhe implorando, deixe-me entrar.

- Vá embora, pois é o lobo e, do mesmo modo como devorou minhas irmãs, quer me devorar.

O lobo dá um empurrão na porta, mas a porta era feita de ferro como toda a casa e o lobo quebra um ombro. Urrando de dor, corre até o ferreiro.

- Conserte o meu ombro - disse-lhe.

- Conserto o ferro, não os ossos - disse o ferreiro.

- Acontece que arrebentei os ossos com o ferro, portanto é você quem deve me consertar - disse o lobo.

Então o ferreiro pegou o martelo e os pregos e lhe consertou o ombro.

O lobo voltou à casa de Marieta e se pôs a falar bem perto da porta:

- Escute, Marietinha, por sua culpa quebrei um ombro, mas gosto de você assim mesmo. Se sair comigo amanhã cedo, vamos colher grãos-de-bico num campo aqui perto.

Marieta respondeu:

- Sim, sim. Venha me buscar.

Mas, esperta como era, percebera que o lobo queria apenas fazÊ-la sair de casa pra devorá-la. Por isso, no dia seguinte, levantou-se antes da aurora, foi ao campo de grãos-de-bico e colheu um avental cheio. Voltou para casa, pôs os grãos-de-bico para cozinhar e jogou as cascas pela janela. Às nove, apareceu o lobo. 
- Marietinha, linda, venha comigo colher os grãos-de-bico.

- Não, não vou de jeito nenhum, tonto: já colhi os grãos-de-bico, olhe embaixo da janela e verá as cascas, cheire a fumaça que sai pela chaminé e sentirá o odor, a você só resta lamber os beiços.

O lobo estava danado de raiva, mas disse:

- Não faz mal, amanhã cedo venho buscá-la às nove e iremos colher tremoços.

- Sim, sim - disse Marieta -, eu o espero às nove.

Porém, levantou-se cedo outra vez, foi ao campo de tremoços, colheu um avental cheio deles e os levou para cozinhar. Quando o lobo veio buscá-la, mostrou-lhe as cascas fora da janela.

O lobo jurava vingança consigo mesmo, mas a ela disse:

- Espertinha, hein, me enganou! - mas continuo gostando muito de você! Amanhã você deve vir comigo a um campo que eu conheço. Lá vamos encontrar abóboras que são uma maravilha e faremos uma bela refeição.

- Mas é claro que vou - disse Marieta.

No dia seguinte correu ao campo das abóboras antes do amanhecer, porém dessa vez o lobo não esperou as nove; e correu também ao campo das abóboras para devorar Marieta de uma só vez.

Assim que Marieta viu o lobo ao longe, não sabendo para onde fugir, fez um buraco numa grande abóbora e se escondeu lá dentro. O lobo, que sentia cheiro de cristão, fareja as abóboras, mexe e remexe e não a encontra. Pensou então: “Já deve ter voltado para casa. Vou me fartar de abóboras sozinho". E começou a comer abóboras desbragadamente.

Marieta tremia ao sentir que o lobo se aproximava de sua abóbora, imaginando que a comeria com ela dentro. Mas quando chegou a vez da abóbora de Marieta, o lobo já estava saciado.

- Esta, que é tão grande - disse -, vou levá-la de presente para Marieta, para que se torne minha amiga. - Abocanhou a abóbora e segurando-a entre os dentes, correu até a casinha de ferro e a jogou pela janela.

- Minha Marietinha! - disse. - Olhe que lindo presente eu lhe trouxe.

Marietinha, já em segurança em sua casa, pulou fora da abóbora, fechou a janela e por trás da vidraça provocou o lobo com os dedos em forma de chifre. 
- Obrigada, amigo lobo - disse-Ihe -, eu estava escondida na abóbora e você me trouxe até em casa.

Ao ouvir isso, o lobo começou a bater a cabeça contra as pedras.

À noite, nevava. Marieta se aquecia junto à lareira, quando ouviu um barulho no tubo da chaminé. "É o lobo que vem me devorar", pensou. Pegou um caldeirão cheio de água e o colocou no fogo para ferver. Devagar, devagarinho, o lobo desce pela chaminé, dá um salto pensando que está saltando em cima da moça, mas cai na água fervendo e morre. Assim, a esperta Marieta se livrou do inimigo e viveu tranqüila por toda a sua vida. 


\section{vI) Conto italiano recolhido na região da Calábria por Italo Calvino ${ }^{6}$}

\section{OS TRÊS ÓRFÃOS}

Um homem com três filhos morreu de doença. Os três filhos se tornaram três órfãos. Certo dia o mais velho disse: - Irmãos, estou de partida. Vou em busca de fortuna. Chegou a uma cidade e começou a gritar pelas ruas:

\section{Quem me quer como empregado considere-me contratado!}

Um grande senhor se debruçou num balcão.

- Se fizermos um acordo, contrato-o como empregado.

- Sim, dê-me o que quiser.

- Mas eu quero obediência.

- E eu vou obedecê-lo em tudo.

De manhã, chamou-o e lhe disse:

- Tome, pegue esta carta, monte neste cavalo e parta. Mas em nenhum momento toque nas rédeas, pois, se tocar nelas, o cavalo retorna. Basta deixá-lo correr, porque ele sabe conduzi-lo até onde a carta deve ser entregue.

Montou no cavalo e partiu. Galopa que galopa, chegou à beira de um despenhadeiro. "Vou cair", pensou o órfão, e puxou as rédeas. O cavalo se virou e regressou ao palácio num piscar de olhos.

O patrão, vendo-o regressar, disse:

- Viu? Não foi aonde eu o tinha mandado! Está despedido. Vá até aquele monte de dinheiro, pegue o que quiser e desapareça.

O órfão encheu os bolsos e foi embora. Assim que saiu, rumou direto para o Inferno.

Vendo que o irmão mais velho não retornava, o segundo dos órfãos decidiu partir também. Percorreu o mesmo caminho, chegou à mesma cidade e também ele começou a gritar:

Quem me quer como empregado

considere-me contratado!

\footnotetext{
${ }^{6}$ Idem, pp. 292-94.
} 
Aquele senhor se debruçou na janela e o chamou. Puseram-se de acordo e, pela manhã, deu-lhe as mesmas instruções que ao irmão e o mandou com a carta. Também ele, assim que chegou à beira do despenhadeiro, puxou as rédeas e o cavalo retornou.

- Agora - disse o patrão -, pegue quanto dinheiro quiser e suma!

Ele encheu os bolsos e partiu. Partiu e foi direto para o Inferno.

Vendo que nem um nem outro irmão voltavam, o irmão caçula partiu também. Percorreu o mesmo caminho, chegou à mesma cidade, gritou "quem me quer como empregado considere-me contratado", aquele senhor se debruçou na janela, mandou-o subir e lhe disse:

- Dou-lhe dinheiro, de comer e o que quiser, desde que me obedeça.

O órfão aceitou e de manhã o patrão the deu a carta com todas as instruções. Tendo chegado à beira daquele despenhadeiro, o moço olhou para baixo, arrepiado, mas pensou: "Que Deus me proteja”, fechou os olhos e, quando os abriu, já estava do outro lado.

Galopa que galopa, chegou a um rio largo como o mar. Ele pensou; "Vou me afogar, o que posso fazer? De resto, estou nas mãos de Deus!". Nisso, a água se dividiu e ele atravessou o rio.

Galopa que galopa, viu uma enxurrada vermelha como sangue. Pensou: "É agora que me afogo. De resto, que Deus me proteja!", e se lançou para frente. Diante do cavalo, a água se dividia.

Galopa que galopa, viu um bosque, tão denso que por ele não passava nem sequer um passarinho. "Aqui me perco", pensou o órfão. "De resto, se eu me perco, perde-se também o cavalo. Que Deus me proteja!", e seguiu adiante.

No bosque, encontrou um velho que cortava uma árvore com um talo de aveia.

- Mas o que está fazendo? - perguntou-lhe. - Pretende cortar uma árvore com um talo de aveia?

E ele:

- Diga mais uma palavra e lhe corto também a cabeça.

O órfão fugiu a galope.

Galopa que galopa, viu um arco de fogo com dois leões, um de cada lado. "Agora, se passar pelo meio me queimo; mas, se eu me queimar, queima-se também o cavalo. Adiante, que Deus nos proteja!" 
Galopa que galopa, viu uma mulher ajoelhada numa pedra, rezando. Lá chegando, o cavalo parou de repente. O órfão entendeu que era àquela mulher que devia entregar a carta, e a entregou a ela. A mulher abriu a carta, leu, depois pegou um punhado de areia e o jogou para o alto. $O$ órfão montou de novo no cavalo e tomou o caminho de volta.

Quando chegou à casa do patrão, este, que era o Senhor, disse-Ihe:

- Saiba que o despenhadeiro era o barranco do Inferno; a água, as lágrimas de minha mãe; o sangue, o de minhas cinco chagas; o bosque, os espinhos de minha coroa; o homem que cortava a árvore com o talo de aveia era a Morte; o arco de fogo, o Inferno; os dois leões eram seus irmãos, e a mulher ajoelhada, minha mãe. Você me obedeceu: pegue quantas moedas de ouro quiser.

O órfão não queria nada, mas acabou pegando uma única moeda e se despediu do Senhor.

No dia seguinte, quando foi fazer compras, pagava e a moeda permanecia em seu bolso. Assim, viveu feliz e contente. 


\section{VII) Conto português recolhido na região do Porto por Teófilo Braga ${ }^{7}$}

\section{A MADRASTA}

Uma mulher tinha uma filha muito feia e uma enteada bonita como o Sol; com inveja tratava-a muito mal, e, quando as duas pequenas iam com uma vaquinha para o monte, à filha dava-lhe um cestinho com ovos cozidos, biscoitos e figos, e à enteada dava-lhe côdeas de broa bolorentas, e não passava algum dia sem lhe dar muita pancada. Estavam uma vez no monte e passou uma velha que era fada, e chegou-se a elas e disse:

- Se as meninas me dessem um bocadinho da sua merenda? Estou mesmo a cair de fome.

A pequena que era bonita e enteada da mulher ruim deu-lhe logo da sua codinha de broa; a pequena feia, que tinha o cestinho cheio de coisas boas, começou a comer e não lhe quis dar nada. A fada quis-lhe dar um castigo, e fez com que ela feia ficasse coma formosura da bonita; e que a bonita ficassem em seu lugar, com a cara feia. Mas as duas pequenas não o souberam; veio a noite e foram para casa. A mulher ruim, que tratava muito mal a enteada que era bonita, veio-Ihes sair ao caminho, porque já era muito tarde, e começou às pancadas com uma vergasta na própria filha, que estava agora com a cara da bonita cuidando que estava a bater na enteada. Foram para casa, e deu de comer sopinhas de leite e coisas boas à que era feia, pensando que era a sua filha, e a outra mandou-a deitar para a palha de uma loja cheia de teias de aranha, e sem ceia. Duraram as coisas assim muito tempo, até que um dia passou um príncipe e viu a menina da cara bonita à janela, muito triste e ficou logo a gostar muito dela, e disse-Ihe que queria vir falar com ela de noite ao quintal. A mulher ruim ouviu tudo, e disse à que estava agora feia e que cuidava que era a sua filha, que se preparasse e que fosse falar à noite com o príncipe, mas que não descobrisse a cara. Assim fez, e a primeira coisa que disse ao príncipe foi - que estava enganado, quer ela era muito feia. o príncipe dizia-Ihe que não, e a pequena descobriu então a cara; mas a fada deu-lhe naquele mesmo instante a sua formosura. O príncipe ficou mais apaixonado e declarou que queria casar com ela; a pequena foi-o dizer à que pensava que

\footnotetext{
${ }^{7}$ BRAGA, T. Op. cit., pp. 119-20.
} 
ela era sua filha. Fez-se o arranjo da boda, e chegou o dia em que vieram buscá-la para se ir casar; ela foi com a cara coberta com um véu e a irmã, que estava agora bonita, ficou fechada na loja às escuras.

Assim que a menina deu a mão ao príncipe e ficaram casados, a fada deu-lhe a sua formosura; foi então que a madrasta conheceu que aquela era a sua enteada e não sua filha. Corre à pressa a casa, vai à loja da palha ver a pequena que lá fechara, e dá com a sua própria filha, que desde a hora do casamento da irmã tornara a ficar com a cara feia. Ficaram ambas desesperadas e não sei como não arrebentaram de inveja. É bem certo o ditado: "Madrasta nem de pasta". 


\section{VIII) Conto português recolhido na região do Algarve por Teófilo Braga ${ }^{8}$}

\section{O SAPATINHO DE CETIM}

Era uma vez um homem viúvo e tinha uma filha; mandava-a à escola de uma mestra que a tratava muito bem e lhe dava sopinhas de mel. Quando a pequenita vinha para casa, pedia ao pai que se casasse com a mestra, porque ela era muito sua amiga. O pai respondia:

- Pois queres que case com a tua mestra? Mas olha que ela hoje te dá sopinhas de mel, e algum dia tas dará de fel.

Tanto teimou, que o pai casou com a mestra; ao fim de um ano teve ela uma menina, e tomou desde então grande birra contra a enteada, porque era mais bonita do que a filha. Quando o pai morreu é que os tormentos da madrasta passaram as marcas. A pobre da criança tinha uma vaquinha que era toda a sua estimação; quando ia para o monte, a madrasta dava-Ihe uma bilha de água e um pão, ameaçando-a com pancadas se ela não trouxesse outra vez tudo como tinha levado. A vaquinha com os pauzinhos tirava o miolo do pão para a menina comer, e quando bebia água tornava a encher-lhe a bilha com a sua baba. Deste feitio enganavam a ruindade da madrasta.

Vai um dia adoeceu a ruim mulher, e quis que se matasse a vaquinha para the fazer caldos. A menina chorou, chorou antes de matar a sua querida vaquinha, e depois foi lavar as tripas ao ribeiro; vai senão quando, escapou-lhe uma tripinha da mão, e correu atrás dela para a apanhar. Tanto andou que foi dar a uma casa de fadas, que estava em grande desarranjo, e tinha lá uma cadelinha a ladrar, a ladrar.

A menina arranjou a casa muito bem, pôs a panela ao lume, e deu um pedaço de pão à cadelinha. Quando as fadas vieram, ela escondeu-se detrás da porta, e a cadelinha pôs-se a gritar:

Ão, ão, ão

Por trás daquela porta

Está quem me deu pão

\footnotetext{
${ }^{8}$ Idem, pp. 292-94.
} 
As fadas deram com a menina, e fadaram-na para que fosse a cara mais linda do mundo, e que quando falasse deitasse pérolas pela boca, e também Ihe deram uma varinha de condão.

A madrasta assim que viu a menina com tantas prendas, perguntou-lhe a causa daquilo tudo, para ver se também as arranjava para a filha. A menina contou o sucedido, mas trocando tudo, que tinha desarrumado a casa, quebrado a louça, e espancado a cadelinha. A madrasta mandou logo a filha, que fez tudo à risca como a mãe lhe dissera tintim por tintim. Quando as fadas voltaram, perguntaram à cadelinha o que tinha sucedido; ela respondeu:

Ão, ão, ão

Por trás daquela porta está

Quem me deu com um bordão

As fadas deram com a rapariga, e logo a fadaram, que fosse a cara mais feia que houvesse no mundo; que quando falasse gaguejasse muito, e que ficasse corcovada. A mãe ficou desesperada quando isto viu, e dali em diante tratou ainda mais mal a enteada.

Houve por aquele tempo uma grande festa dos anos do príncipe; no primeiro dia foi a madrasta ao arraial com a filha, e não quis levar consigo a enteada que ficou a fazer o jantar. A menina pediu à varinha de condão que lhe desse um vestido da cor do céu e todo recamado com estrelas de ouro, e foi para a festa; todos estavam pasmados e o príncipe não tirava os olhos dela. Quando acabou a festa, a madrasta veio já achá-la em casa a fazer o jantar, e na se cansava de gabar o vestido que vira. No segundo dia foi a menina à festa, com o poder da varinha de condão, e com um vestido de campo verde semeado de flores. No terceiro dia, quando a menina viu que a madrasta já tinha ido para casa, partiu a toda a pressa, e caiu-lhe do pé um sapatinho de cetim. O príncipe assim que vou aquilo correu a apanhar o sapatinho, e ficou pasmado com a sua pequenez. Mandou deitar um pregão: que a mulher a quem pertencesse o sapatinho de cetim seria sua desposada. Correram todas as casas e a ninguém servia o sapatinho. Foi por fim à casa da mulher ruim, que apresentou a filha ao príncipe, mas o pé era uma patola e não cabia no sapatinho de cetim; perguntou-Ihe se não tinha mais alguém em casa. Quando a madrasta ia responder que não, abriu-se a porta da cozinha, e apareceu a enteada com o vestido do primeiro dia das festas e com um pezinho descalço, 
que serviu no sapatinho de cetim. O príncipe levou-a logo consigo, e à madrasta deu-lhe tal raiva, que se botou da janela abaixo e morreu arrebentada. 


\section{IX) Conto português recolhido na região de Trás-os-montes e alto Douro por Joaquim Alves Ferreira ${ }^{9}$}

\section{A PRINCESA DOS CABELOS DE OIRO}

Era uma vez uma princesa muito linda que tinha longas tranças de oiro e era o enlevo de seus pais. Mas, um dia, a mãe faleceu e o pai voltou a casar-se com uma mulher muito má que não gostava dela e fazia tudo para a tornar infeliz.

O seu ódio aumentou, quando Ihe nasceu uma filha. Então, conseguiu virar contra ela o próprio pai e, com o seu consentimento, mandou os criados arrastá-la para uma floresta. e abandoná-la, para ser comida pelas feras. Mas as feras não the fizeram qualquer mal. Pelo contrário, afeiçoaram-se à linda princesinha, que, passados alguns dias, pôde regressar à corte, em cima do dorso dum lobo seu amigo.

A madrasta, ao vê-la, ficou muito contrariada e mandou-a levar para um longínquo deserto, para aí morrer à fome e à sede. Mas também aí apareceu uma águia que a protegeu e conduziu de novo ao palácio real.

Furiosa com mais uma contrariedade, a madrasta ordenou que a enterrassem viva, no canto do jardim. Os criados fizeram uma cova muito funda e meteram lá dentro a pobre princesinha. Mas, antes que a cobrissem com terra, abriu-se misteriosamente, debaixo dos seus pés, um grande portão de bronze e a menina foi dar a um palácio doirado, onde vivia um príncipe muito rico, mas encantado sob a fora dum pavão, à espera duma princesa que o fosse desencantar.

Ao ver aquele pavão tão lindo, com penas verdes, azuis e amarelas, a menina acariciou-o com as suas mãozinhas e logo o pavão se transformou num jovem encantador, que lhe disse sorrindo:

- Obrigado, linda princesa, por me teres quebrado o encanto. Como prova da minha gratidão, serás, de hoje em diante, a dona deste palácio, se quiseres aceitar-me por seu esposo.

A princesa aceitou, naturalmente satisfeita, e tornou-se a rainha do palácio, com muitas aias à sua disposição para lhe satisfazerem todos os desejos.

\footnotetext{
${ }^{9}$ FERREIRA, J. A. Op. cit., pp. 239-40.
} 
Mas aquela felicidade inesperada não the fez esquecer o seu velho pai, que ela continuava a amar, apesar de todo o mal que the fizera. Por isso, cheia de saudade, todas as noites, mandava uma fada, com uma luzinha na mão, cantar uma música suave, sobre a cova, onde fora sepultada, para chamar a atenção da corte.

Quando el-rei deu conta daquele estranho fenómeno, mandou abrir a cova, para tentar descobrir-Ihe a causa. Os criados revolveram a terra e encontraram, bem lá no fundo da cova, o misterioso portão de bronze. Mas, quando o rei quis abri-lo, foi impedido por um dragão que lhe disse:

- Deixa a princesa descansada, nesta sua linda morada. E toma muita cautela, que ainda hás-de precisar dela.

O rei mandou tapar novamente a cova e regressou muito triste ao palácio, a pensar nas palavras do dragão. para agravar a sua tristeza, abateu sobre todo o reino um ano de fome e doenças que dizimavam a população.

Vendo-se incapaz de evitar aqueles flagelos e tomando-os por castigo do seu cruel procedimento para com a filha, cheio de remorsos e de arrependimento, não fazia senão chorar junto da sepultura.

E foi numa dessas circunstâncias que sentiu, estupefacto, a cova abrirse e sair dela uma linda menina que lhe enxugou carinhosamente as lágrimas, o tomou pela mão e conduziu ao palácio subterrâneo. Depois, levou-o à sala do trono, mostrou-lhe a rainha, com um manto de seda branca aos ombros e uma coroa de oiro e pedras preciosas na cabeça, e disse-lhe:

- Aquela rainha é a filha que tu mandaste enterrar. Mas não tenhas qualquer receio: foi ela que te mandou chamar, para te conceder o perdão e a ajuda necessária para salvares o teu reino.

Então o pai avançou para a filha, a filha desceu do trono e os dois caíram nos braços um do outro, a chorar de alegria.

Depois, a rainha apresentou ao pai o seu esposo, já desencantado, e os três saíram do palácio subterrâneo, com as aias e o tesouro, e regressaram, felizes, ao antigo palácio da princesa dos cabelos de oiro.

E, com eles, voltou a alegria ao palácio e a prosperidade a todo o reino justificando a sabedoria popular: há males que vêm por bem. 


\section{x) Conto africano recontado por Lourenço Rosário ${ }^{10}$}

\section{O RAPAZ DO CONHO}

Havia na povoação de Mopeia uma rapariga linda como a lua.

Chegada a altura de casar vieram rapazes das redondezas, dos mais valentes e aguerridos pedir aos pais que os deixassem casar com a rapariga. Todos os rapazes foram incapazes de resolver os problemas que o pai da rapariga ia colocando a cada um.

$\mathrm{Na}$ aldeia de Malulu vivia um pobre órfão, numa cabana abandonada. Tinha o corpo coberto de sarna, não comia nem bebia havia vários dias porque quando saía à rua os cães seguiam-no e lambiam-lhe o corpo. O nome desse rapaz era "Nziwaeka", que quer dizer "Sabe tudo".

Um dia Nziwaeka ouviu contar as belezas da rapariga e soube das provas exigidas. "Eu vou tentar, talvez tenha sorte". Os da aldeia de Malulu riram-se e zombaram dele: "Quem és tu, desgraçado, mal cheiroso. Nem sequer te deixarão aproximar para pedires uma prova". E faziam-lhe saber que os rapazes de todos os lados, desde Caia, Beira, Marromeu, até Chupanga, sem falar os da própria aldeia da rapariga, todos foram incapazes de ficar com a rapariga.

Mas Nziwaeka era teimoso e lá foi. A viagem de Malulu até Mopeia durou três dias e três noites. Na primeira noite, Nziwaeka encontrou uma velha leprosa numa cabana abandonada. Chovia torrencialmente e a velha quase que morria de frio, porque estava mal agasalhada. $O$ rapaz tirou a sua capulana e envolveu com ela a velha ficando ele apenas de calções e tronco nu. A velha agradeceu e em paga deu-lhe uma boceta ${ }^{11}$ e disse: "Que os teus desejos se encontrem todos nesta boceta".

$\mathrm{Na}$ segunda noite, Nziwaeka encontrou outra velha. Esta velha estava carregada de feridas mal cheirosas. O rapaz lavou-lhe as chagas e tirou do seu calção algumas tiras com que ligou as feridas expostas às moscas. A velha ficou muito agradecida e deu-lhe um cão e disse: "Que este cão faça tudo o que mandares e dê a sua vida por ti". E Nziwaeka seguiu caminho.

${ }^{10}$ ROSÁRIO, L. Op. cit., pp. 214-217. 
$\mathrm{Na}$ terceira noite, o rapaz encontrou uma outra velha a gemer de fome. Nziwaeka foi às bananeiras mais próximas colheu um cacho, procurou lume, assou-as e deu a comer à velha. Esta agradecida disse-lhe: "Sempre que precisares de auxílio é só gritares'Mama leka, mama leka' e verás o que pode acontecer".

Nziwaeka chegou a Mopeia ao amanhecer e foi logo ter com o pai da rapariga. Mas este, ao vê-lo sarnoso e roto, nem quis recebê-lo. O rapaz lembrou-se da boceta e ordenou: "Boceta, boceta, quero um lindo fato, bom sapato, óculos e chapéu". Tudo aconteceu como ele mandou. E toda a gente ficou admirada ao ver aquele rapaz transformado. "Qual é a prova afinal?" Perguntou Nziwaeka. "É fácil, pega neste cacho de bananas vai ao Conho assa-as e trá-las ainda quentinhas", respondeu o pai da rapariga. De Mopeia até ao conho demora-se um dia inteiro a andar como homem.

Nziwaeka pegou no cacho e foi andando, andando. Chegou ao pé de um rio parou para beber pois tinha sede, mas logo veio um passarinho e cantou:

Ninguém sente a dor

Caída sobre as gentes do Conho

Tu que tranqüilamente bebes água

Que sabes tu das desgraças dos homens?

Para o ano as mulheres vão à Beira

Pois elas hoje constroem casas

E os homens do Conho? Que desgraça

Onde se viu um homem pegar em panelas

Tu que tranqüilamente bebes água

Salva os homens do Conho

E o fogo jamais se extinga

Nas terras desgraçadas do Conho

O rapaz não bebeu mais água. Ficou muito intrigado com aquela canção porque não Ihe compreendia o sentido.

Andou, andou e chegou ao Conho eram três horas, o sol estava ao meio da tarde. Então vou os homens junto à lareira a preparar as refeições e alguns outros a brincar com as crianças. As mulheres estavam empoleiradas a construir palhoças, umas no tecto outras a carregar capim e outras a cortar os paus. Viu igualmente que na lagoa do Conho as mulheres lançavam redes e

$\overline{11}$ Caixinha redonda, oval ou oblonga, feita de materiais diversos e usada para guardar pequenos objetos. 
pescavam bois, cabritos, porcos, galinhas e outros animais que vivem com 0 homem. E os homens em terra, cuidavam de peixes e outros animais das águas.

Nziwaeka ficou de tal maneira confuso com o que via que lhe faltou discernimento para continuar com sua missão. Esqueceu-se completamente da missão que o levou àquela povoação.

Quando os outros homens o viram disseram: "Olá! temos mais um companheiro; ainda bem que chegaste, o serviço é muito. Vem, junta-te a nós".

Os homens pareciam felizes com o trabalho doméstico. E Nziwaeka ficou enfeitiçado com aquela situação que já não se lembrava de assar as bananas.

O cão começou a latir, os outros homens disseram: "O que faz um cão aqui fora, se todos os animais domésticos estão na água?" Nziwaeka pegou numa corda e correu atrás do cão para amarrá-lo e atirá-lo para o rio. O cão tentou fugir mas Nziwaeka conseguiu pará-lo. la a atirá-lo para o rio quando o passarinho cantou de novo:

Ninguém sente a dor

Caída sobre as gentes do Conho

Tu que tranqüilamente atiras o cão à água

Que sabes tu das desgraças dos homens?

Para o ano as mulheres vão à Beira

Pois elas hoje constroem casas

E os homens do Conho? Que desgraça

Desde quando é que o homem pega em panelas

Tu que tranqüilamente atiras o cão à água

Pára e salva os homens do Conho

E o fogo jamais se extinguirá

Nas terras desgraçadas do Conho

Nziwaeka ficou estático, pois o canto do passarinho não lhe era totalmente estranho, apesar de estar esquecido de tudo. Foi então que o cão aproveitou e ferrou-Ihe uma dentada muito forte. O rapaz gemeu e gritou: "Mama leka, mama leka", o que queria dizer deixa-me por favor, deixa-me por favor. Mas ao dizer semelhante frase recuperou de imediato a memória e ficou muito triste ao ver que tinha amarrado o seu cão para atirá-lo à água. 
Pegou então na boceta e disse: "Boceta, boceta, ajuda-me a compreender a situação para que eu possa assar as bananas sem correr riscos". De imediato se transformou em Administrador. Ordenou então que os homens fossem para o seu devido lugar e as mulheres regressassem para junto da lareira e dos filhos. Os homens disseram: "Nós não podemos, senhor Administrador, estamos enfeitiçados e não sabemos fazer o que nos manda, só a feiticeira de Morrumbala nos pode salvar e o fogo não se apagará jamais da nossa aldeia".

Então Nziwaeka compreendeu que aquilo tinha acontecido porque as gentes daquela povoação tinham deixado extinguir o fogo completamente e, por castigo foram colocados em tarefas contrárias. Nziwaeka disse para a boceta: "Boceta, boceta, ajuda-me a resolver a situação para que eu possa assar as bananas e regressar para junto da rapariga com quem quero casar". De repente apareceu a feiticeira de Morrumbala que acendeu a fogueira e tratou os homens e as mulheres que de imediato deram conta da troca dos lugares e farefas e ficaram muito envergonhados, correram a atirar os peixes todos à água e recuperaram todos os animais que estavam na lagoa.

Nziwaeka assou as bananas no fogo que não se apaga e regressou a Mopeia. Mas como a distância é longa o rapaz pediu de novo o auxílio da boceta que o pôs num instante junto dos pais da rapariga com as bananas ainda bem quentes.

Perante tais factos, a rapariga foi entregue ao rapaz que casou e ganhou muito dinheiro e viveram muito tempo e tiveram muitos filhos. 